
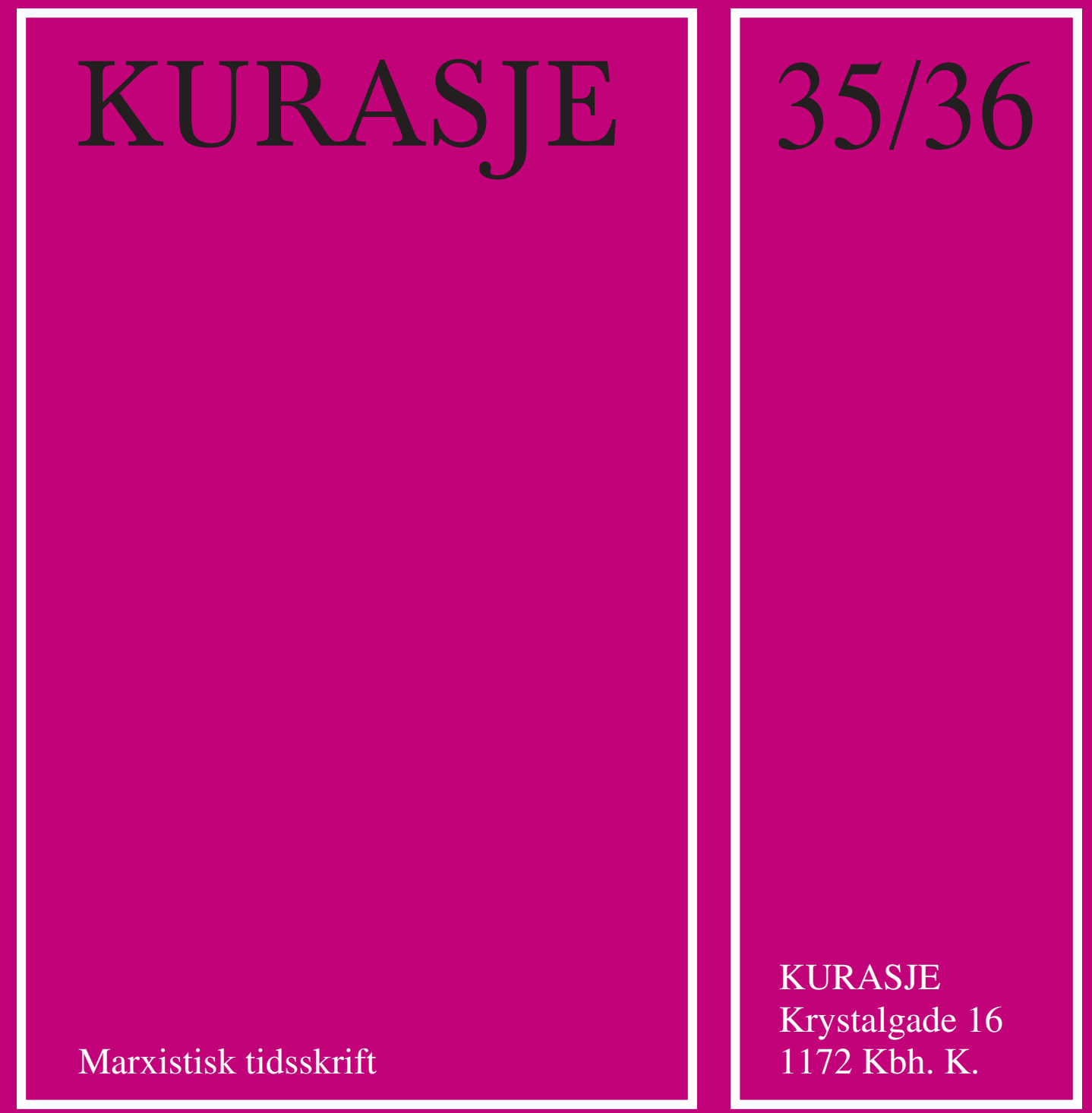

\title{
DOBBELTNUMMER OM:
}

subjektivitet, Marx og den moderne verden, moderniseringspolitik, ungdomsbevægelser, verdensmarked, bogen om lønarbejdet, konkurrenceteori, Marx Weber, normativitet og proletariat, og meget andet godt. 


\section{Abonnement på kurasje nr. 37-40 koster følgende:}

Biblioteker

Støtteabonnementer

Studerende o.lign.

Folk med fast arbejde
$200 \mathrm{kr}$.

$200 \mathrm{kr}$.

$140 \mathrm{kr}$.

$180 \mathrm{kr}$.

Særtilbud: nr. 29-32 incl. samlet for 100,- kr.

Kurasjes gironummer: 7166044

Kurasje

Krystalgade 16

1172 København K ekspeditionstid:

(hver onsd. 20-23)

Telf.: 01-14 7151

\section{Sats: G.M.T. Tryk: Special-Trykkeriet Viborg a-s}

Udgivet med støtte fra Statens Samfundsvidenskabelige Forskningsråd.

Tidsskriftet behandler en lang række emner med det formål at bidrage til etableringen af en konkret formidlet kritik af det kapitalistiske system og det borgerlige samfund, samt til diskussionen af overgangsformer til det kommunistiske samfund. Vi opfordrer interesserede til at indsende manuskripter til redaktionen.

Kontaktpersoner:

Århus: Hans-Jørgen Thomsen, Heibergsgade 25"II 8000 Århus C.

Aalborg: Peter Søndergaard, Faldtvej 14, 9330 Dronninglund Helsinki: Arto Noro, Sociologisk Institut, Helsinki Universitet Jyväskylä: Jürgen Ritsert, Fachbereich Gesellschaftswissenschaft, J. W. Goethe Universität, Frankfurt. 


\section{TIDSSKRIFTET KURASJE}

Nr. 35/36

Marts 1985

\section{Indhold}

Michael A. Lebowitz

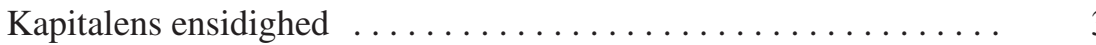

Jürgen Hoffmann

Moderniseringspolitik som arena for arbejdspolitikken ....... 29

Klaus Busch

Om forholdet mellem politik og $\varnothing$ konomi

på det kapitalistiske verdensmarked

Jürgen Ritsert

Weber eller Marx - Om konstellationen mellem idealtyperne

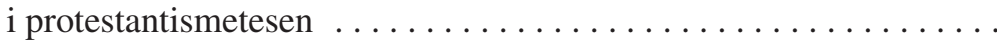

Lars Bjфrnshauge

Ungdomsprotest - »Ny subjektivitet«,

modstand eller integration?

Michael Eldred, Marnie Hanlon, Lucia Kleber og Mike Roth

Værdiformsanalytisk rekonstruktion af Kapitalen

Del 4 ................................

Kommentarer og anmeldelser

Steen Nepper Larsen og Lars Petersen

Metafysikkens praktiske virkeliggørelse

- kapitalistisk udviklingslogik i det moderne kaos . . . . . . . 163

Jens Henning Rasmussen

Noget om dét som er og dét som bør være

Redaktionen: Bjarne Andersson, Nils Bredsdorff, Jens Brinch, Peter Bundesen, Leif Hansen, Finn Hansson, Mogens Holm, Peder Lærke Nielsen, Finn Dam Rsmussen, Jens Henning Rasmussen, Peter Søndergaard og HansJørgen Thomsen.

Redaktionens adresse:

Kurasje, Krystalgade 16, DK 1172 København K. 

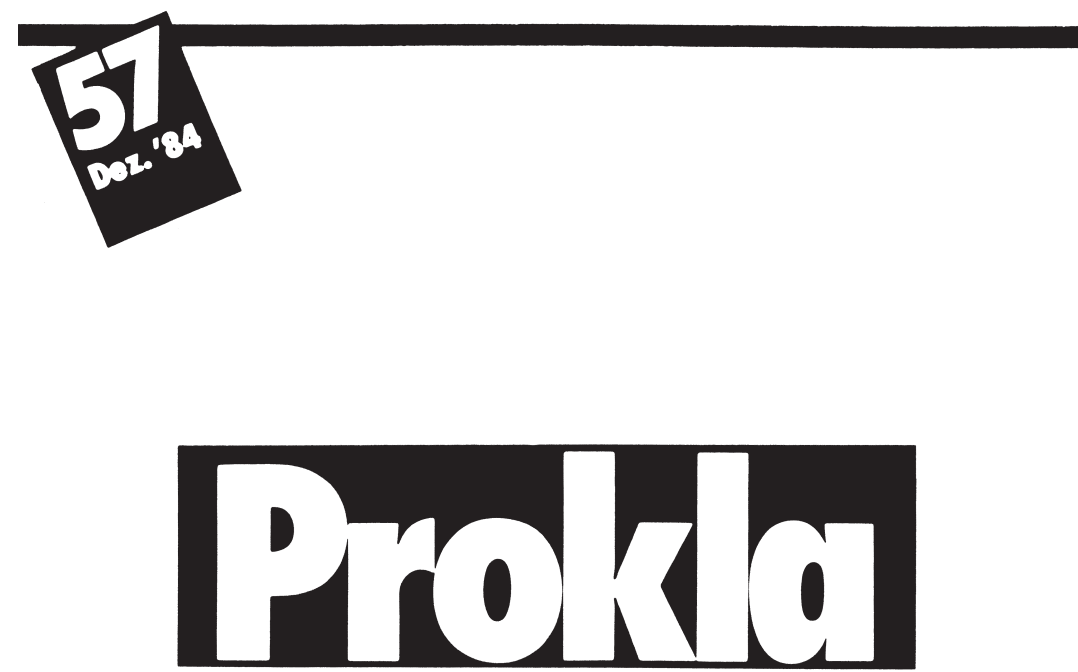

\section{Zeitschrift für politische Ökonomie und socialistische Politik}

\section{Krise der Ökonomi - Versagen der Krisentheorie?}

Paul Mattick, Wert und Kapital / Götz Rohwer, Rainer Künzel, Dirk Ipsen, Marx und die gegenwärtige Akkumulationskrise / Jörg Glombowski, Michael Krüger, Profit-squeeze und Fall der Profitrate als elemente eines integrierten Überakkumulationsansatzes / Alfred Kleinknecht, Innovationsschübe und Lange Wellen: Was bringen "Neo-Schumpeterianische" Kriseninterpretationen? / Rod Coombs, Die Verbreitung von Mechanisierungstechniken und Theorien der Langen Wellen / Uwe Traber, Monetäre und reproduktive Akkumulation / Michael Stanger, Zur Dynamik von Arbeitsmarktstrukturen / Uwe Becker, Zum Status der Klassentheorie und der klassentheoretisch fundierten Politikanalyse - heute

\section{Abonnementspris 54,- $\mathrm{kr}$.}

Enkeltpris 67,50 kr.

Tegn abonnement hos Kurasje 


\section{Kapitalens ensidighed.*}

Michael A. Lebowitz

I modsætning til, hvad Rosdolsky (og de fleste andre forskere) mener, er den bog om, lønarbejdet, som Marx havde planlagt, aldrig blevet indlemmet som en del af Kapitalen. Derfor udgør Kapitalen ikke en adækvat udviklet totalitet, et organisk hele, hvor alle forudsætninger også fremstår som resultater. Produktionen af lønarbejdet, som er en betingelse for kapitalens reproduktion, står således udenfor kapitalen; den er en forudsætning, men ikke et resultat. Med den logiske udvikling af lønarbejdssiden kan der, imidlertid konstrueres en adækvat totalitet (kapitalismen som helhed), som indeholder både »arbejderens eget behov for udvikling « og kapitalens behov for værdiøgning -dvs. to-sidet klassekamp.

Vi skal her undersøge visse implikationer af Kapitalens ensidighed, herunder også de mangler, som har fået nogle til at foreslå, at man dropper begrebet om arbejdskraften som en vare.

\section{Lønarbejdet: Den manglende bog ${ }^{1 \mathrm{a}}$}

Dialektisk logik kræver, at man forstår en genstand i dens sammenhænge og ikke isoleret. Hvordan skal vi så forstå Kapitalen? I sin oprindelige plan forestillede Marx sig en unders øgelse, som skulle bestå af seks bøger:

*Oversat fra The Review of Radical Political Economics, vol. 14 no. 4 1982, s. $40-51$ af Mogens Andersen.

1a. De centrale dele af denne artikel indgik i et paper, »Capital as Finite«, som blev fremlagt for et Marx-seminar, arrangeret af Department of Philosophy, University of Victoria i oktober 1980. 
kapitalen, jordejendommen, lønarbejdet, staten, international handel og verdensmarkedet. ${ }^{1}$ Hvordan skal vi så forstå Kapitalen?

Man kunne forestille sig, at den oprindelige plan blev overskredet, at dens kerne nu skulle være indeholdt i de tre første bøger - og at de emner, som skulle have været behandlet i bindene om jordejendommen og lønarbejdet til sidst blev indlemmet i Kapitalen. Denne position, som indtages af forskere som Rosdolsky, betragter de eventuelle manglende bøger og dermed Kapitalens mangelfulde og ufuldendte karakter som et relativt uvæsentligt spørgsmål:

I hvert fald synes de væsentlige temaer i bogen om lønarbejdet og i bogen om jordejendommen optaget i manuskriptet fra 1864-66 til det endelige værks I og III bind. Dermed blev de oprindeligt planlagte seks bøger reduceret til een eneste - bogen om kapitalen².

Marx har selv givet udtryk for, at de emner, som skulle behandles under $»$ jordejendommen «, er blevet optaget i Kapitalen ${ }^{3}$. Der findes imidlertid ikke tilsvarende vidnesbyrd, hvad angår det planlagte bind om lønarbejdet; det er alene gennem følgeslutninger, at Rosdolsky når frem til f.eks. den konklusion, at »alle emner i den tidligere bog om lønarbejdet... fandtes indenfor rammerne af Kapitalens I. bind $\aleph^{4}$. Hvor holdbart er egentlig grundlaget for denne konklusion?

Rosdolsky fremhæver som sit væsentligste argument, at den diskussion om lønnen og dens former, som i modstrid med den oprindelige plan indgår som del VI af Kapitalens I. bind, faktisk skulle have udgjort størstedelen af den planlagte bog om lønarbejdet; på et eller andet tidspunkt, 1864 eller senere, har Marx ifølge Rosdolsky besluttet sig for at gøre dette materiale til en del af Kapitalen og dermed afveget fra sin oprindelige plan $^{5}$. Det er imidlertid højst tvivlsomt, om det materiale, som blev medtaget i Kapitalen, udgjorde »alle emner « eller blot de »væsentligste emner « $\mathrm{i}$ den planlagte bog om lønarbejdet - hvis de da overhovedet var tænkt som en del af denne bog. Rosdolsky modsiger da også senere i sin bog sin egen argumentation; i en diskussion af den antagelse, Marx gør i Kapitalen, at mængden af arbejdernes livsfornødenheder skal betragtes som konstant, hævder han således, at dette ikke udelukker, at »den gennemsnitlige mængde livsfornødenheder« kan vokse:

1. Marx til Engels, 2. april 1858, jvf. Karl Marx and Frederick Engels. Selected Correspondence, Moskva 1965, s. 104.

2. R. Rosdolsky: Kapitalens tilblivelseshistorie, Århus 1975, s. 21.

3. Marx til Engels, 2. august 1862, jvf. Karl Marx and Frederick Engels, Selected Correspondence, op.cit., s. 128-29.

4. R. Rosdolsky: Kapitalens tilblivelseshistorie, op.cit., s. 31 og s. 65.

5. ibid., s. 27 og s. 67-68. 
Denne situation ville Marx imidlertid først have kunnet tage hensyn til i den af ham planlagte »specielle lære om lønarbejdet«, hvis han var kommet til at udføre også denne del af sin plan 6 .

Her er en kritisk brist i påstanden om, at de væsentligste emner i bogen om lønarbejdet er blevet indlemmet i Kapitalen. De mere vidtgående diskussioner af, hvorledes kapitalen skaber nye behov hos arbejderne, unders $\varnothing$ gelsen af variationer i mængden af arbejdernes livsfornødenheder - alt dette blev eksplicit af Marx udskudt til bogen om lønarbejdet for ikke at »blande det hele sammen «. ${ }^{7}$ Så sent som i 1864-65 bemærkede Marx i sin skitse til det »oprindelige kapital seks « i Kapitalen (som Rosdolsky tilsyneladende ikke har haft kendskab til):

mennesket udmærker sig i forhold til alle andre dyr ved ikke at have skranker eller udstrækningsmæssige grænser for sine behov ... Selve niveauet for livsbehovene, hvis samlede værdi udgør arbejdsevnens værdi, kan stige eller synke. Men analysen af disse variationer hører ikke ind her, men i læren om arbejdslønnen ${ }^{8}$.

Denne analyse er imidlertid aldrig blevet optaget i Kapitalen - »niveauet for livsbehovene « betragtes her som givet, som en given størrelse for et "givet land i en given periode «. Her er der i hvert tilfælde ét emne - måske endda et meget væsentligt emne - som ikke blev optaget som en del af Kapitalen.

Denne tavshed er i sig selv bemærkelsesværdig; den afslører, at Kapitalen ikke er den kilde, man skal gå til, hvis man vil vide noget om Marx' syn på reallønnens udvikling over tid. I modsætning til Joan Robinsons fortolkning påstod Marx aldrig, at »reallønnen tenderer til at være konstant «; dette var blot en antagelse, som skulle ophæves i den bog om lønarbejdet, som aldrig blev skrevet ${ }^{9}$. Man må imidlertid gå videre og spørge - hvor meget andet er heller ikke blevet optaget i Kapitalen? Kort sagt, hvad skulle bogen om lønarbejdet have indeholdt? Hvis væsentlige emner først skulle have været behandlet i bogen om lønarbejdet, i hvilken grad må man så betragte selve Kapitalen som mangelfuld og utilstrækkelig? På baggrund af Bowles’ og Gintis' artikel for nylig i tidsskriftet The Review of Radical Political Economics, hvor de foreslår, at man kan

6. ibid., s. 262n.

7. M.A. Lebowitz: Capital and the Production of Needs, Science and Society, Vol. XLI, No. 4, 197778, s. 430-447.

8. K. Marx: Resultater af den umiddelbare produktionsproces, Århus 1974, s. 167-69.

9. M.A. Lebowitz: Capital and the Production of Needs, op.cit., s. 442-47. 
afhjælpe Kapitalens mangelfulde karakter ved bl.a. at droppe begrebet om arbejdskraften som en vare og arbejdet som arbejdskraftens brugsværdi, er det særlig vigtigt at undersøge, i hvor høj grad problemet ligger i den $\gg$ manglende $\operatorname{bog} «^{10}$.

Det vil naturligvis ikke være muligt alene ud fra den manglende bog at konkludere, at Kapitalen er utilstrækkelig.

Det vil også være nødvendigt at finde ud af »nøjagtig hvilke emner, der skulle have været behandlet i bogen om lønarbejdet«. Vi kan imidlertid ikke her ligesom Rosdolsky hovedsagelig basere os på en sammenligning af Grundrisse og Kapitalen ${ }^{11}$. En sådan rekonstruktion ville blot være en eklektisk samling af udvendige citater; det ville være det samme som at indrømme, at man hverken havde forstået eller kunne anvende Marx' dialektisk logiske metode. Vi må vide mere om, hvad der med sikkerhed skulle have været optaget i bogen om lønarbejdet, ligesom vi også har brug for en målestok til bestemmelse af utilstrækkelighed. For begge deles vedkommende vil det kræve, at vi går til selve Kapitalen, og at vi underkaster den en logisk undersøgelse.

\section{Kapitalen som utilstrækkelig ${ }^{12 a}$}

For at Kapitalen, bogen, kan betragtes som tilstrækkelig, må den give en tilstrækkelig fremstilling af kapitalen, relationen. Kapitalen må fremstilles som en totalitet, en organisk helhed, hvor alle forudsætninger fremstår som resultater, hvor »ethvert sat forhold således samtidigt er forudsætning «, som det er »tilfældet med ethvert organisk system $\ll^{12}$. Gennem en deduktionsproces må man vise, hvorledes alle helhedens dele logisk er forbundet med hinanden, således at intet element fremstår som eksternt, ydre, ligegyldigt eller fremmed i forhold til systemet - men tværtimod som »forskelle indenfor en enhed «. På denne måde kan totalitetens iboende tendenser eller iboende love afdækkes; og denne fremstilling af det

10. S. Bowles og H. Gintis: Structure and Practice in the Labor Theory of Value, Review of Radical Political Economy, Vol. 12, No. 41981.

11. R. Rosdolsky: Kapitalens tilblivelsesproces, op.cit., s. 13.

12a. Diskussionen af kapitalens dialektik bygger på M.A. Lebowitz: Marx’ Methodological Project, manuskript 1980. Det er langt fra den eneste dialektiske fortolkning af Kapitalen; læsere af The Review of Radical Political Economics vil have kunnet stifte bekendtskab med Harry Cleavers dialektiske fortolkning (H. Cleaver: Reading Capital Politically, Harvester Press 1979). Som en anden, desværre overset, behandling af emnet, kan nævnes R. Dunayevskaya: Marxism and Freedom, New York 1964 -en bog, som var med til at åbne mine øjne for Hegel og Lenins Hegel-fortolkning. Forskellen på den foreliggende artikel og disse og andre indlæg i debatten er, at jeg i min diskussion af Kapitalen forsøger at påvise dens utilstrækkelighed.

12. K. Marx: Grundrids til kritikken af den politiske økonomi, København 1974-77, s. 176. 
indre, væsenet må gå forud for undersøgelsen og udviklingen af totalitetens nødvendige fremtrædelsesformer, »mangfoldigheden af dens ydre former « og også forud for den måde, hvorpå de indre tendenser fremtræder og sætter sig igennem på overfladen.

Dette skal ikke forstås som et krav til videnskab som sådan - det er ikke den problematik, jeg interesserer mig for her - men er blot en beskrivelse af Marx' fremgangsmåde i Kapitalen. Marx havde nemlig helt præcist til hensigt at fremstille kapitalen som et hele, kapitalen som en totalitet, hvor den »indre sammenhæng mellem de $\varnothing$ konomiske kategorier eller det borgerlige $\varnothing$ konomiske systems skjulte bygning « ville blive afdækket, og midlet til udvikling af denne totalitet var en dialektisk tankeproces, som skulle sikre, at intet $»$ formidlende led « blev udeladt ${ }^{13}$.

Da vi ikke i detaljer kan følge alle de skridt, der er nødvendige for konstruktionen af Kapitalens totalitet, vil det her være tilstrækkeligt at beskrive processens væsentligste momenter. Marx tog udgangspunkt i varen, rigdommens elementære form i et kapitalistisk samfund, og fortsatte med at analysere den som konkret genstand, som et arbejdsprodukt der sælges, og han opdagede, at den indeholdt en distinktion - at den på den ene side var brugsværdi og på den anden side værdi. I sin videre unders $\emptyset$ gelse fandt han at selve varebegrebet latent indeholdt begrebet om penge - at varen i sig selv og for sig selv kun eksisterede i byttet, kun ved at forvandle sig til penge, værdiens selvstændige udtryk. Varens eksistens som sådan forudsætter, at værdien antager en selvstændig form, og dette sker med »tvedelingen af varen i vare og penge $\aleph^{14}$. Den forskel mellem brugsværdi og værdi, som var indeholdt $i$ varen, får således et ydre udtryk i modsætningen mellem vare og penge ${ }^{15}$.

Som selvstændig værdi er penge (varens fordobling) også brugsværdi; de har den egenskab at kunne repræsentere og realisere enhver anden vares værdi, at kunne byttes med enhver anden vare. Det er denne egenskab, der gør det muligt for pengene at optræde som formidler for varebyttet (V-P-V). Det ligger imidlertid latent i pengene, at de kan optræde som mål i sig selv, at penge som rigdom kan være målet - her er det således varen, der er formidler og forsvindende moment. Penge for sig (P-V-P) er imidlertid blot værdi; i pengenes bevægelse som rigdom er værdien almen og til stede $\mathrm{i}$ alle former - både penge og vare fungerer »som forskellige eksistensmåder af selve værdien $\aleph^{16}$. Værdien-for-sig bevæger sig

13. K. Marx: Teorier om merværdien, 2. bog 1, København 1979, s. 187.

14. K. Marx: Kapitalen 1. bog 1, København 1970, s. 189.

15. ibid., s. 208.

16. ibid., s. 267. 
her som processens subjekt gennem penge- og vareformen. For den selvudvidende værdi, den selv-valoriserende værdi, værdi-for-sig, er vare og penge blot formidlere, forsvindende momenter, blotte former i kapitalens særlige enhed. For sig eksisterer penge således kun ved at forvandle sig til kapital, til selv-udvidende værdi; der sker en differentiering i penge, som går til forbrug, og penge, som lægges ud, dvs. penge som penge og penge som kapital.

Marx konkluderede videre, at også kapitalen indeholder en dobbelthed. Oprindelig fremstod kapitalen som en enhed af vare og penge: imidlertid viser det sig nu, at kapitalen i cirkulationssfæren (for at eksistere som selv-udvidende værdi) forudsætter en proces hinsides cirkulationen - nemlig en produktionsproces. Kapitalen fremstår dermed dobbelt som kapital i cirkulationen og kapital i produktionen. Kapitalen må forlade cirkulationssfæren og indgå i produktionssfæren; og det er her, i produktionen, vi kan så hvorledes kapitalen som selv-udvidende værdi producerer merværdi, dvs. sikrer produktionen af varer, som indeholder merværdi. Imidlertid er denne merværdi i vareform kun latent; for at blive realiseret må kapitalen vende tilbage til cirkulationssfæren, og varen må byttes mod penge. Kapitalen må altid vende tilbage til sit udgangspunkt, cirkulationen. Kapitalen i produktionen er formidler for kapitalen i cirkulationen. På den anden side er kapitalen i cirkulationen også formidler for kapitalen i produktionen; kapitalen kan kun vokse ved at gennemløbe cirkulationen. De to processer er modsætninger, de udelukker gensidigt hinanden, men er også nødvendige for hinanden - og de udgør en særlig enhed, kapitalen

Figur I: Konstruktionen af kapitalen som totalitet.

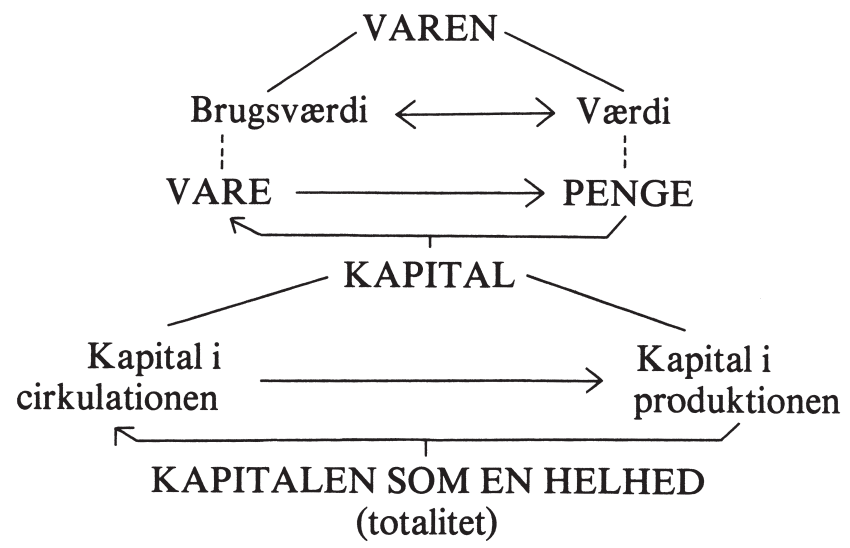


som helhed ${ }^{17}$. Kapitalen som helhed, kapitalen som totalitet antager begge former, altså både cirkulationskapitalens form og produktionskapitalens form - ligesom den også antager varernes og pengenes form. De enkelte trin i kontruktionen af denne totalitet kan ses i Figur I.)

Den totalitet, som Marx konstruerer i Kapitalen, er således kapitalen som helhed; momenterne af denne enhed af produktion og cirkulation kommer klart til udtryk i titlerne på Kapitalens tre bind. Som en sådan totalitet må kapitalen bevæge sig gennem et stadigt kredsløb, som kan beskrives ud fra flere forskellige synsvinkler. Set som pengekapitalens kredsløb begynder vi med penge-kapital $(\mathrm{P})$, som køber varer $(\mathrm{V})$, nemlig både produktionsmidler (Pm) og arbejdskraft (Ak); efter den mellemliggende produktionsproces $(\mathrm{Pr})$, hvor der produceres varer (V), med et indhold af merværdi, vender kapitalen tilbage til sin pengeform gennem udveksling af varer mod penge (V'-P'):

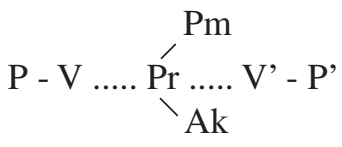

Alternativt kan man betragte kredsløbet ud fra den produktive kapitals synsvinkel (dvs. begynde og slutte med Pr) eller ud fra varekapitalens synsvinkel (dvs. begynde og slutte med V'). Hver for sig er de tre kredsløbsformer imidlertid utilstrækkelige og ensidige: kapitalens kredsløb må forstås som alle tre former samtidig, hvilket lettest lader sig illustrere som en »cirkel« (således som den er fremstillet i Figur II).

Figur II: Kapitalens kredsløb som helhed.

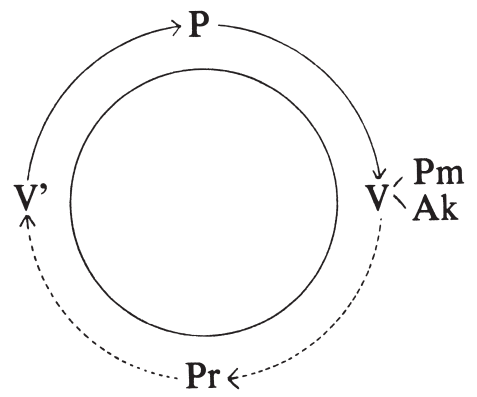

17. M.A. Lebowitz: Marx' Falling Rate of Profit: A Dialectical View, Canadian Journal of Economics, Vol IX, No. 2, maj 1976, s. 232-54. 
Om kapitalens kredsløb som helhed bemærkede Marx, at »alle forudsætninger for processen ... fremtræder ... som dens resultat, som en forudsætning, produceret af processen selv. Ethvert moment fremtræder som udgangspunkt, gennemgangspunkt og returpunkt $\aleph^{18}$. Kort sagt alle betingelser og alle forudsætninger fremstår selv som resultater indenfor kapitalens kreds$1 \varnothing b$ - dette er præcist kapitalens natur forstået som totalitet, kapital som reproduktionsproces:

Hvis en cirkel uafbrudt roterer, er ethvert punkt på den på samme tid begyndelses- og slutpunkt..... Kapitalens reproduktion i enhver af sine former og på ethvert af sine stadier er lige så kontinuerlig som disse formers metamorfoser og det successive forløb gennem de tre stadier ${ }^{19}$.

Kort sagt, reproduktion (forstået som reproduktion af både materielle produkter og produktionsrelationer) er det centrale begreb for den organiske helhed, det centrale begreb for kapitalen som totalitet. I de reproduktionsmodeller, hvormed Marx afslutter bind II af Kapitalen, fremstilles produktionens to afdelinger (produktionsmidler og livsfornødenheder) som afdelinger, der reproducerer reproduktionens betingelser, forudsætningerne, og i denne fremstilling betragtes kapitalen som en helhed, en enhed af produktion og cirkulation. På samme måde er selve begrebet om den simple reproduktion et begreb for den organiske helhed. Som Marx bemærkede i de første linier af kapitel 21 i Kapitalens første bind, dvs. kapitlet om »Simpel reproduktion «:

Uanset den samfundsmæssige form, produktionsprocessen måtte have, må den være kontinuert, dvs. hele tiden periodisk gennemløbe de samme stadier på ny. Lige så lidt som et samfund kan holde op med at forbruge, kan det ophøre med at producere. Enhver samfundsmæssig produktionsproces er derfor også en reproduktionsproces, når man betragter den i en fortsat sammenhæng og i dens fornyelses stadige strøm ${ }^{20}$.

På denne måde producerer og reproducerer kapitalen forstået som totalitet, som sammenhængende helhed, materielle produkter og sociale relationer, som selv er produktionens forudsætninger og betingelser. »De pågældende betingelser er ligesom disse relationer på den ene side forudsætninger, på den anden side resultater, skabt af den kapitalistiske produktionsproces; de

18. K. Marx: Kapitalen, 2. bog 1, København 1971, s. 127.

19. ibid., s. 128.

20. K. Marx: Kapitalen, 1. bog 4, København 1971, s. 803. 
produceres og reproduceres af denne $\ll^{21}$. Kort sagt kan kapitalen som helhed betragtes som et lukket socialt input-output-system, hvor ingen faktorer fremstår som eksogene. Og her, efter at have fremstillet kapitalen som helhed, fortsætter Marx med »at finde frem til og beskrive de konkrete former, der vokser frem af kapitalens bevogelsesproces, betragtet som helhed «; det er nu muligt »skridt for skridt...(at nærme sig). . den form, hvori de selv optræder på samfundets overflade $\ll^{22}$.

Dette rejser imidlertid helt klart et spørgsmål (måske mindre klart hvis Kapitalens logiske struktur fremstår uklart): udgør kapitalen som helhed virkelig en adækvat totalitet? Er der virkelig tale om en organisk helhed, hvor alle forudsætninger samtidig er resultater, hvor alle udgangspunkter også er returpunkter? Eller indeholder kapitalen som helhed selv en dobbelthed, en dobbelthed, som forbyder os at standse her (selv blot for en kort pause)? Svaret på dette klare spørgsmål er også klart. Der eksisterer nemlig et element, som ikke er en del af kapitalen, som ikke produceres og reproduceres af kapitalen, som er udgangspunkt, men ikke returpunkt i kapitalens kredsløb, en forudsætning, som ikke samtidig fremstår som et resultat af selve kapitalen. Det drejer sig om et element, som er nødvendigt for kapitalens reproduktion, en betingelse for selve kapitalens eksistens. Denne pointe fremhæves i kapitlet om »Simpel reproduktion«i Kapitalens første bind:

Den stadige opretholdelse og reproduktion af arbejderklassen er og bliver den stadige betingelse for kapitalens reproduktion. Kapitalisten kan trøstigt overlade dens opfyldelse til arbejdernes selvopholdelses- og forplantningsdrift $\mathrm{f}^{23}$.

Denne pointe - at kapitalen er afhængig af noget udenforstående, arbejderens produktion - er for væsentlig til blot at være baseret på et enkelt citat (selv om det er muligt at finde andre). Hvis kapitalen som helhed faktisk udgør en adækvat totalitet, bør det også fremgå af en nøjere undersøgelse af dens reproduktion, en unders $\emptyset$ gelse af dens reproduktionsmodel og af kapitalens kredsløb.

Lad os først betragte modellen for simpel reproduktion i Kapitalens andet bind. Her præsenteres vi for to produktionsafdelinger: Afdeling I (produktionsmidler) og Afdeling II (konsumtionsmidler). I hver afdeling er der to inputs i produktionen - produktionsmidler og arbejdskraft (og dermed to

21. K. Marx: Kapitalen, 3. bog 4, København 1972, s. 1054.

22. K. Marx: Kapitalen, 3. bog 1, København 1972, s. 36.

23. K. Marx, Kapitalen, 1. bog 4, op.cit., s. 811. 
værdikilder - konstant kapital og levende arbejde $-\mathrm{k}+(\mathrm{v}+\mathrm{m}))$; processen har også to outputs - produktionsmidler $(\mathrm{Pm})$ og konsumtionsmidler $(\mathrm{Km})$. Det ene output, produktionsmidler, er også samtidig et input; det er både produktionens resultat og forudsætning. Derimod er det andet output, konsumtionsmidler, ikke samtidig et input; og det andet input, arbejdskraft, er ikke samtidig et output. Modellen er faktisk ikke lukket i sig selv: der er tre variable (Pm, Km, Ak) og kun to produktionsprocesser.

Hvis vi betragter den betingelse for simpel reproduktion, ligevægt, som kan udledes af denne model, dvs. at $\mathrm{k}_{2}=\mathrm{v}_{1}+\mathrm{m}_{1}$, ser vi, at den ikke opfylder reproduktionens krav, hvis vi angiver, at reproduktionen skal omfatte reproduktion af et givet antal nødvendige arbejdere. Denne betingelse angiver blot, at antallet af arbejdere i hver afdeling (eller alternativt, mængden af nyt arbejde i hver afdeling) skal stå i et bestemt forhold til hinanden; den kan med andre ord opfyldes ved forskellige niveauer for den samlede beskæftigelse - ligevægt ved fuld beskæftigelse, ligevægt ved under fuld beskæftigelse osv. ${ }^{24}$. Kort sagt findes der en »frihedsgrad «, som netop skyldes den kendsgerning, at modellen ikke er lukket, den kendsgerning, at et lukket system kræver en »tredie« afdeling.

Det samme kan illustreres grafisk i forhold til kapitalens kredsl $\varnothing b$ afbildet som en cirkel. Vi må først erkende, at kredsløbet, som det er fremstillet i Figur II, er utilstrækkeligt, fordi det ikke skelner mellem de to forskellige typer af varer, som produceres under kapitalistiske forhold - produktionsmidler og konsumtionsmidler; denne skelnen, som er nødvendig for reproduktionen, må indføjes i kredsløbet, hvis det skal give et korrekt billede af reproduktionsprocessen. Vi ser nu, at kredsløbet både indeholder en udveksling af penge med produktionsmidler (P-Pm) og en udveksling af produktionsmidler med penge (Pm-P) - hvilket er den samme handling set ud fra forskellige synsvinkler; produktionsmidler er klart både en forudsætning og et resultat indenfor kapitalens kredsløb.

Dette understreger imidlertid blot den manglende symmetri (som har været skjult) mellem arbejdskraft og konsumtionsmidler: der foregår en udveksling af penge med arbejdskraft (P-Ak) og en udveksling af konsumtionsmidler med penge (Km-P); arbejdskraft er imidlertid kun en forudsætning og konsumtionsmidler kun et resultat indenfor kapitalens kredsløb. For at alle forudsætninger skal fremstå som resultater og alle resultater skal fremstå som forudsætninger er det således nødvendigt at

24. $\mathrm{k}_{2}=\mathrm{v}_{1}+\mathrm{m}_{1}$. Heraf følger $\mathrm{v}_{2}\left(\mathrm{k}_{2} / \mathrm{v}_{2}\right)=\mathrm{v}_{1}\left(1+\mathrm{m}_{1} / \mathrm{v}_{1}\right)$ og $\mathrm{v}_{2} / \mathrm{v}_{1}=\left(1+\mathrm{m}_{1} / \mathrm{v}_{1}\right)\left(\mathrm{k}_{2} / \mathrm{v}_{2}\right)$. Dette forhold må være identisk med forholdet mellem antallet af arbejdere $\mathrm{i}$ afdeling $2 \mathrm{og}$ antallet af arbejdere $\mathrm{i}$ afdeling $1, \mathrm{a}_{2} / \mathrm{A}_{1}$; men heraf følger ikke at $\mathrm{A}_{1}+\mathrm{A}_{2}=\mathrm{A}_{\mathrm{r}}$, Hvor $\mathrm{A}_{\mathrm{r}}$ er det totale antal arbejdere. 
bestemme endnu et forhold - nemlig forholdet mellem konsumtionsmidler og arbejdskraft.

Det første skridt vi må tage for at lukke dette system må være eksplicit at erkende den metamorfose, som sker indenfor cirkulationen, når arbejdskraften byttes mod penge, som dernæst byttes mod konsumtionsmidler (Ak-P-Km); begge led i denne metamorfose er allerede forudsat ved kapitalens bevægelser indenfor sit kredsløb -P-Ak, Km-P. Dette er imidlertid ikke tilstrækkeligt; arbejdskraften er nemlig her blot fastholdt som forudsætning uden samtidig at være resultat. Vi har arbejdskraftens konsumtion, men ikke dens produktion, og konsumtionsmidlernes produktion, men ikke deres konsumtion. Kort sagt kan systemet kun fuldendes ved at indføre endnu en produktionsproces, et andet moment af produktionen (P-A), som er forskelligt fra kapitalens produktionsproces - nemlig produktion af arbejdskraft gennem konsumtion af konsumtionsmidler. Kapitalens kredsløb forudsætter et andet kredsløb, lønarbejdets kredsløb (således som det er afbildet i Figur III).

Figur III: Kapitalens og lønarbejdets kredsløb.

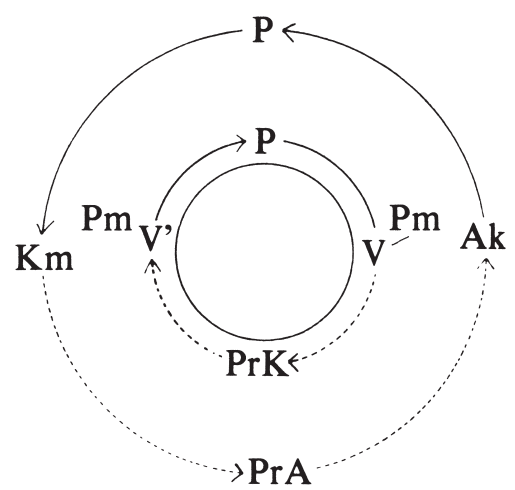

Nødvendigheden af dette andet moment af produktionen, arbejderens produktion (PrA), kaster lys over den bemærkning Marx gør i Grundrisse om opdelingen af det samlede kapitalkredsløb i fire momenter: »hver af de to store momenter, produktionsprocessen og cirkulationsprocessen, fremstår igen dobbelt «. To af disse fire momenter var cirkulationens momenter (P-V, V'-P'), og en tredie var den kapitalistiske produktionsproces. Disse tre momenter fremstår som momenter indenfor kapitalen som helhed, indenfor kapitalens kredsløb. Men hvad var det fjerde moment - den anden produktionsproces? Marx bemærkede, at dette moment skulle betragtes separat; 
det indeholdt udvekslingen af variabel kapital mod levende arbejdsevne, og »her er populationen hovedsagen «. Hvor skulle dette moment af produktionen analyseres? »Moment IV hører hjemme i afsnittet om arbejdsløn etc. $\ll^{25}$.

Kapitalen som helhed, som totalitet, indeholder derfor ikke denne »nødvendige betingelse for kapitalens reproduktion « - arbejderklassens opretholdelse og reproduktion. »Arbejderklassens stadige eksistens er imidlertid en nødvendighed for kapitalistklassen; dette gælder derfor også arbejderens individuelle konsumtion, der formidles gennem $\mathrm{P}-\mathrm{V}$ «. Men arbejderens individuelle konsumtion falder ikke indenfor kapitalens kredsløb; dette gælder kun for den produktive konsumtion, kapitalens produktionsproces ${ }^{26}$.

Kapitalen som helhed udgør således ikke en adækvat totalitet, hvor alle forudsætninger, alle betingelser, fremstår som resultater. Undersøgelsen har vist, at den ikke eksisterer på egen hånd uden en nødvendig relation til et andet; kapitalen viser sig at indeholde en dobbelthed - den må sætte lønarbejderen udenfor sig for at eksistere som sådan. Det er således nødvendigt at undersøge lønarbejdet som det eksisterer udenfor kapitalen. Som Marx på et tidligt tidspunkt bemærkede om den politiske $\varnothing$ konomi, en politisk $\emptyset$ konomi, som kun betragter arbejderen som et arbejdende dyr og ikke »når han ikke arbejder, som et menneske « - »Lad os nu hæve os over den politiske $\varnothing$ konomis niveau « ${ }^{27}$. På samme måde er det nu tiden, hvor vi skal hæve os over kapitalens politiske økonomi; kapitalen udgør kun et moment indenfor en adækvat totalitet.

\section{Lønarbejdets placering}

Kapitalen som helhed er ikke et slutpunkt, men deler sig videre i kapital på den ene side og lønarbejde på den anden. Efter den indledende undersøgelse af kapitalsiden, skal vi nu undersøge lønarbejdssiden.

Hidtil har vi betragtet lønarbejdet, således som det indgår som moment i kapitalen, som det eksisterer for kapitalen. I Kapitalen, altså i bogen, præsenteres vi først for lønarbejdet i form af lønarbejderen som er adskilt fra produktionsmidlerne, som ikke-kapital overfor kapitalen, som besidder af en brugsværdi for kapitalen - den eneste brugsværdi for kapitalen som sådan, arbejdskraft. Arbejdskraft står som brugsværdi overfor penge, ligesom

25. K. Marx: Grundrids..., op.cit., s. 390.

26. K. Marx: Kapitalen, 2. bog 1, op.cit., s. 96.

27. K. Marx: Economic and Philosophic Manuschripts of 1844, i K. Marx \& F. Engels: Collected Works, Vol. 3, New York 1975, s. 241. 
penge i cirkulationssfæren sfæren står som værdi overfor arbejdskraft; kapital, værdi-for-sig, sætter her en uafhængig brugsværdi udenfor sig.

Efter bytteprocessens afslutning ( $\mathrm{k} \varnothing \mathrm{b}$ og salg af arbejdskraft), går vi ind i den kapitalistiske produktionsproces, hvor den brugsværdi, kapitalen har købt, konsumeres, hvor arbejdskraftens realisering (arbejde) underlægges kapitalen. Her ser vi, hvorledes lønarbejderen, underkastet kapitalens vilje, tvinges til at arbejde for at opfylde kapitalens mål, valorisering (selv-udvidelse). Til sidst møder vi på ny lønarbejderen i cirkulationssfæren (V'- P'), hvor kapitalen søger at realisere den merværdi, som er indeholdt i de producerede varer.

Således er lønarbejdet til stede i ethvert moment af kapitalen. Det eksisterer for kapitalen som et nødvendigt middel for kapitalens vækst; det optræder som formidler for kapitalen. Værdien-for-sig sætter en uafhængig brugsværdi for at være for sig. Indenfor kapitalens kredsløb er der imidlertid allerede en dobbelthed, som peger ud over den. Kapitalen står ikke blot overfor lønarbejderen som besidder af brugsværdi; den må også nødvendigvis træde i kontakt med lønarbejderen som besidder af værdi i cirkulationssfæren ( $\mathrm{V}^{\prime}$ - P'). Kapitalen optræder ikke kun som værdi i forhold til lønarbejdet; den er også, i sin vareform, brugsværdi for lønarbejdet.

Lønarbejde forholder sig således til kapitalen i dennes vareform som værdi til brugsværdi $(\mathrm{P}-\mathrm{Km})$. Kapitalen må naturligvis være brugsværdi for at kunne realiseres som værdi. Spørgsmålet er så, hvad der kan være brugsværdi for lønarbejdet i denne cirkulationssfære. Og dette spørgsmål kan ligeså lidt som det tilsvarende spørgsmål om kapitalen besvares med en henvisning til cirkulationssfæren. For at kapitalen kan være brugsværdi for lønarbejdet, må den være brugsværdi i den produktionssfære, hvor den konsumeres som sådan. Det er nødvendigt at bevæge sig ud over lønarbejdets cirkulationssfære og ind i lønarbejdets produktionssfære.

Abstrakt betragtet fremstår dette nødvendige udgangspunkt, arbejderens produktionsproces, som en naturlig produktionsproces; hvis man imidlertid betragter den som helhed, fremstår den som en særlig realtions reproduktionsproces - nemlig lønarbejdets. For det første er denne produktionsproces umiddelbart en konsumtionsproces:

At mennesket f.eks. i indtagelsen af føde - en form for konsumtion - producerer sin egen krop, er klart. Dette gælder imidlertid om enhver anden form for konsumtion, der på den ene eller anden måde producerer mennesket i en eller anden henseende ${ }^{28}$.

28. K. Marx: Grundrids..., op.cit., s. 12. 
Arbejderens produktionsproces er kort sagt en proces, hvor der konsumeres brugsværdier; og disse brugsværdier er ikke blot de fysiologisk nødvendige, men enhver brugsværdi, som producerer arbejderen »i en eller anden henseende «.

For det andet er resultatet af denne produktionsproces arbejderen selv. »Hvad nu angår arbejderens konsumtion, så reproducerer den ét - nemlig ham selv som levende arbejdsformåen $\ll^{29}$. Der er her tale om en »forvandling « af livsfornødenheder til »frisk arbejdskraft«; kort sagt, »den individuelle konsumtions produkt er ... konsumenten selv $\ll^{30}$.

Endelig for det tredie er arbejderens produktionsproces en arbejdsproces. Denne bestemmelse indeholder to aspekter. For det første er denne proces en aktivitet - den proces, hvori der konsumeres brugsværdier for at producere arbejderen, er altså ikke passiv, men aktiv. Den tid, der bruges til denne aktivitet kan ikke sættes op som modsætning til den tid, der bruges direkte i den kapitalistiske arbejdsproces; der er altså ikke tale om ikkeproducerende tid, fritid, som modsætning til umiddelbar arbejdstid:

At selve den umiddelbare arbejdstid iøvrigt ikke kan forblive i den abstrakte modsætning til den frie tid - således som den synes at gøre fra den borgerlige $\varnothing$ konomis standpunkt - er indlysende ${ }^{31}$.

Tværtimod, det, der foregår i »den frie tid «, er en produktionsproces, en proces, hvor arbejderens natur og evner ændres. Det er »tid til den fulde udvikling af individet, der selv igen som den største produktivkraft virker tilbage på arbejdets produktivkraft « ${ }^{32}$. Denne anden produktionsproces, som den politiske $\varnothing$ konomi overser, er netop den proces, hvori arbejderen produceres:

Den kan ud fra den umiddelbare produktionsproces' standpunkt betragtes som produktion af fast kapital; denne faste kapital er da mennesket selv ${ }^{33}$.

Gennem denne aktivitet sker der således en ændring af mennesket. Idet mennesket forholder sig aktivt til sine omgivelser »ændrer det samtidig sin egen natur ${ }^{34}$. »Den frie tid - der er såvel tid til hvile som tid til højere

29. ibid., s. 522.

30. 30 K. Marx: Kapitalen, 1. bog 4, op.cit., s. 811; K. Marx: Kapitalen, 1. bog 2, København 1970, s. 309-10.

31. K. Marx: Grundrids..., s. 553.

32. ibid., s. 552-53.

33. ibid., s. 553.

34. K. Marx: Kapitalen, 1. bog og 2, op.cit., s. 302. Bemærk også: »producenterne ændrer sig, idet de ud fra sig sætter nye kvaliteter, udvikler, omformer sig selv gennem produktionen, danner nye kræfter og nye forestillinger, nye samkvemsformer, nye behov og nyt sprog « (K. Marx: Grundrids..., op.cit. 367). 
aktiviteter - har naturligt forvandlet sin besidder til et andet subjekt, og som dette andet subjekt træder han (besidderen) også ind i den umiddelbare produktionsproces $\ll^{35}$. Gennem denne aktivitet, hvor der på samme tid bruges og dannes arbejdskraft, producerer arbejderen sig selv som en særlig type af arbejdskraft ${ }^{36}$. Enhver brugsværdikonsumtion producerer ham i en eller anden henseende; enhver aktivitetsproces ændrer ham som det subjekt, der indgår i alle aktiviteter. Som Marx bemærkede i »Teorier om merværdien«:

Mennesket selv udgør grundlaget for sin materielle produktion såvel som for enhver anden produktion, det udfører. Alle omstændigheder, som påvirker mennesket, produktionens subjekt, modificerer altså plus ou moins alle dets funktioner og aktiviteter, således også dets funktioner og aktiviteter som skaber af materiel rigdom, af varer. ${ }^{37}$

Arbejderens produktionsproces, betragtet som arbejdsproces, kan fremstilles på følgende måde:

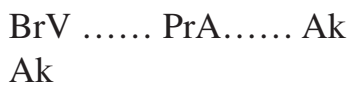

hvor arbejdskraften (Ak) både er input og output og brugsværdierne (BrV) er produktionsmidler, som konsumeres i denne produktionsproces. Vi kan her bemærke, at disse brugsværdier, som helt klart ikke fremstår som processens output, både omfatter brugsværdier, der er produceret direkte som varer, og andre brugsværdier, som ikke nødvendigvis er produceret under kapitalistiske forhold ${ }^{38 a}$.

Det andet aspekt af arbejderens produktion betragtet som arbejdsproces er, at den aktivitet, som indgår i denne proces, er en »formålsbestemt aktivitet«. Med andre ord er der et forudbestemt mål, et mål, som har bevidsthedsmæssig eksistens før selve processen; og denne særlige arbejdsproces er en proces, hvor målet realiseres, idet arbejderens vilje underordnes dette ${ }^{38}$.

35. K. Marx: Grundrids..., op.cit., s. 553.

36. ibid., s. 553.

37. K. Marx: Teorier om merværdien, 1. bog 2, København 1979, s. 334.

38a. På trods af den formelle lighed med Bowles \& Gintis og Cleaver (Bowles \& Gintis: op- .cit., s. 10-11; H. Cleaver: Malaria, The Politics of Public Health and the International Crises, Review of Radical political Economy, Vol. 9, No. 1, 1977. s. 96-99), skal det understreges at de unders $\emptyset$ gte processer er forskellige - vi unders $\emptyset$ ger således her subjektets selv-produktion. Vi har ikke gjort noget forsøg på at give en fremstilling af husarbejdet (som er korrekt bestemt når vi først har undersøgt lønarbejdet som sådan). Der ligger naturligvis her en implicit kritik af det synspunkt, at husarbejde producerer arbejdskraft.

38. K. Marx: Kapitalen, 1. bog 2, op.cit., s. 303. 
Og hvad er så det mål, som eksisterer latent før arbejderens produktionsproces? Det består i arbejderens samfundsbestemte begreb om sig selv. Det er det, »som skaber produktionens ideelle, drivende grund «; det er det, som »sætter produktionens genstand ideelt, som indre billede, som behov, som motiv og som formål $\ll^{39}$. Produktionens forudfattede mål er her »arbejderens udviklingsbehov $\aleph^{40}$. Dette mål som er samfundsbestemt, da kategorien »menneske « $\mathrm{i}$ sig selv er uden behov, er en forudsætning for denne særlige produktionsproces. ${ }^{41 \mathrm{a}} 41$

Ligesom kapitalens produktionsproces har kapitalens valorisering som mål, har arbejderens produktionsproces som sit mål »arbejderens eget behov for udvikling «. På den ene side har vi kapitalen for sig; på den anden side har vi arbejdskraften for sig, brugsværdi for sig. I arbejderens produktionsproces $» g ø r$ mennesket selve sin livsaktivitet til objekt for sin vilje og sin bevidsthed... Hans eget liv er et objekt for ham $\aleph^{42}$. Arbejderen $»$ tilhører (her) sig selv « ${ }^{43}$.

Arbejderens produktionsproces, betragtet som arbejdsproces, er derfor en »simpel« arbejdsproces, hvor mennesker benytter sig af produktionsmidler for at realisere deres eget forudbestemte mål, hvor de behersker deres arbejdes betingelser og resultater, hvor deres arbejde ikke er adskilt fra deres selv, men faktisk en aktivitet for selvet, for deres $\gg$ egeninteresse $\ll^{44}$.

Hvad er nu kravene til denne særlige arbejdsproces? For det første må de nødvendige produktionsmid ler være tilgængelige for arbejderen; han må være i stand til at sikre sig de brugsværdier, der er nødvendige for realiseringen af det opstillede mål. Der er ikke her tale om brugsværdier i sig selv, men kun brugsværdier set i forhold til produktionens mål; brugsværdierne må svare til de samfundsmæssigt udviklede individers behov. Disse behov, som er en del af arbejderens natur, er konstituerende for kategorien »faktiske samfundsmæssige behov«; de er ikke kun begrænset til fysiologiske behov, men kan f.eks. også omfatte:

39. K. Marx: Grundrids..., op.cit., s. 13.

40. K. Marx: Kapitalen, 1. bog 4, op.cit., s. 876.

41a. For at mildne anklagerne for »abstrakt humanisme « (og andre, mere alvorlige forseelser), kan det nævnes, at et senere trin $\mathrm{i}$ argumentation ville medregne patriarkatets reproduktion blandt de mandlige lønarbejderes mål.

41. K. Marx: Notes on Adolph Wagner, i T. Carvers: Karl Marx: Tects on Method, Oxford 1975, s. 189.

42. K. Marx: Economic and Philosophic Manuscripts of 1844, op.cit., s. 276.

43. K. Marx: Kapitalen, 1. bog 4, op.cit., s. 810.

44. ibid., s. 811. 
den andel, arbejderen tager af højere og også åndelige nydelser, agitationer for sine egne interesser, at holde aviser, høre forelæsninger, opdrage børn, udvikle smag etc. ${ }^{45}$.

En anden betingelse for denne særlige arbejdsproces er arbejdskraften selv. Da arbejdsprocessen er en aktivitetsproces, må der eksistere en kraft, som gør det muligt at udføre aktiviteten; der må forekomme både den hertil nødvendige energi (»styrke, sundhed og kraft «) - da der kun er en bestemt mængde »livskraft « til rådighed -og den særlige kvalitet og evne (som selv er et produkt af tidligere aktivitet ${ }^{46}$. Tilsvarende (men adskilt fra selve denne kraft) må der være tid til denne arbejdsproces: »Det er tiden, der afgiver plads for den menneskelige udvikling ${ }^{47}$. Som Marx bemærkede i sit kapitel om arbejdsdagen:

Arbejderen behøver tid til at tilfredsstille sine åndelige og sociale behov, hvis omfang og antal er betinget af det almene kulturelle stade ${ }^{48}$.

Kort sagt, i denne produktionsproces, hvor målet er arbejderens udvikling, behøver arbejderen tid (»fri tid«) til sin fulde udvikling:

Tid til menneskelig dannelse, til åndelig udvikling, til opfyldelse af sociale funktioner, til selskabeligt samvær, til de fysiske og åndelige kræfters frie udfoldelse ${ }^{49}$.

Hvilke muligheder har arbejderen nu for at realisere sine mål? Lad os se nærmere på arbejderens produktionsproces - ikke blot på, hvad der produceres, men også på, hvad der ikke produceres. Processens resultat er arbejderen som levende arbejdsevne; dette er processens eneste produkt. De brugsværdier, som er nødvendige forudsætninger, bliver ikke produceret og er altså ikke resultater - der er derfor ikke tale om et reproduktionssystem. De lader sig faktisk ikke producere indenfor denne proces, da lønarbejdet per definition er adskilt fra de hertil nødvendige produktionsmidler; når denne adskillelse er givet, kan arbejdskraften »hverken anvendes direkte til produktion af brugsværdier for den, der besidder arbejdskraften, eller til produktion af

45. K. Marx: Grundrids..., op.cit., s. 183.

46. K. Marx: Kapitalen, 1. bog 2, op.cit., s. 368 og s. 370.

47. K. Marx: Løn, pris og profit, i K. Marx og F. Engels: Udvalgte Skrifter, Bind I, København 1971, s. 434.

48. K. Marx: Kapitalen, 1. bog 2, op.cit., s. 369.

49. ibid., s. 408. 
varer, som han kunne leve af at sælge $\aleph^{50}$. Og ikke nok med, at arbejderen ikke producerer de brugsværdier, han har brug for - han destruerer dem også i denne produktionsproces, som samtidig er en konsumtionsproces, en proces, som »kun reproducerer individet med dets behov « ${ }^{51}$. Denne særlige arbejdsproces er kort sagt ikke en naturlig produktionsproces, men derimod produktion af en særlig samfundsmæssig relation, produktion af lønarbejdet:

(Den reproducerer) selve individet i en bestemt tilværelsesmåde, ikke kun i dets umiddelbare vitalitet og i bestemte sociale relationer. Så at den endelige tilegnelse gennem individerne, der finder sted i konsumtionsprocessen, reproducerer dem i de oprindelige relationer, hvori de træder til produktionsprocessen og til hinanden; $\ldots . . .{ }^{52}$

For således at producere sig selv, må lønarbejderen sikre sig brugsværdier, som har deres oprindelse udenfor hans egen produktionsproces. Under de herskende betingelser må han tage den eneste potentielle vare han er i besiddelse af, levende arbejdsevne, og påny bevæge sig ind i cirkulationssfæren; han må finde den køber, for hvem den er en brugsværdi - kapitalen. For at være for sig, må arbejderen være for en anden.

Vi har her arbejderen som lønarbejder for sig - som et individ, der forholder sig til kapitalen som et middel, et middel, hvis mål er arbejderen for sig. Kapitalen står altså ikke her overfor en lønarbejder for kapitalen, men overfor en lønarbejder for sig. Kort sagt vi betragtede i første omgang relationen mellem kapital og lønarbejde som en K-La-K-relation, hvor lønarbejdet er formidler for kapitalen, og kapitalen er målet. Nu ser vi imidlertid, at relationen også kan være La-K-La, hvor kapitalen er formidler for lønarbejderen, hvor lønarbejderen er målet i sig, hvor arbejde for kapitalen blot er et middel og slet ikke et mål. Kapitalen er her et moment i lønarbejdets reproduktion. For at kapitalen kan optræde som formidler for lønarbejdet, må lønarbejdet imidlertid optræde som formidler for kapitalen.

I denne cirkulationssfære, hvor arbejderen udbyder sin arbejdskraft som vare, hvor han blot står overfor kapitalen som besidder af brugsværdi, er »arbejderen formelt sat som en person, der tillige er noget for sig selv ud over sit arbejde, og som kun afhænder sin livsytring som middel for sit eget liv ${ }^{53}$. Ikke nok med, at arbejderen sætter sin levende arbejds-

50. K. Marx: Kapitalen, 2. bog 1, op.cit., s. 45.

51. K. Marx: Kapitalen 1. bog 4, op.cit., s. 812.

52. K. Marx: Grundrids..., op.cit., s. 556-57n.

53. ibid., s. 185. 
evne som adskilt fra sig selv i cirkulationen; denne adskillelse fremstår og realiseres også i produktionsprocessen, hvor kapitalen konsumerer arbejdskraft. Her bruger arbejderen sig selv i overensstemmelse med kapitalens mål og under kapitalens opsyn og kontrol; der er her tale om en »spejlvendt « arbejdsproces, hvor det ikke er arbejderen, der anvender arbejdsbetingelserne, men tværtimod arbejdsbetingelserne, der anvender $\operatorname{arbejderen}^{54}$.

Arbejderen må derfor deltage i en aktivitet, som ikke er for ham selv. I stedet for at arbejde for sig selv, arbejder han »for kapitalisten, og derfor også under kapitalisten $\ll^{55}$. Det drejer sig om en proces, hvor arbejderen modsætter sig »kapitalens dominans«, hvor kapitalen bestandig kæmper med »arbejdernes opsætsighed $~^{56}$. På samme måde fører arbejderne en kamp for at få »sat grænser for kapitalens tyranniske usurpation«. De kæmper om arbejdsdagens længde og arbejdets intensitet for at bevare levende arbejdsevne for sig selv, de kæmper om arbejdsdagens længde for at få tid til sig selv ${ }^{57}$. Således ser vi, at der bag diskussionen i Kapitalen om kampen om arbejdsdagens længde ligger noget, som endnu ikke er udviklet i Kapitalen - lønarbejderen som værende-for-sig; disse kampe ligger selv latent i lønarbejderens produktionsproces. ${ }^{58 \mathrm{a}}$

Endelig er kapitalens produktionsproces, denne proces, hvor »lønarbejderens subjektive forhold til sin egen aktivitet « korrekt kan udtrykkes som et »offer«, en aktivitet, som selv producerer lønarbejderen som et særligt samfundsmæssigt udviklet individ, som et individ med $»$ behov for at besidde $\ll^{58}$. Således frembringer den kapitalistiske produktion, som både producerer den fremmede vare og den fremmedgjorte arbejder, bestandig nye behov hos arbejderen $^{59}$. (Lønarbejdets mål, som oprindelig blev betragtet som forudsætning for sin egen arbejdsproces, betragtes her selv som resultat.) Videre kan disse behov ikke realiseres fuldt ud - den kapitalistiske produktion er begrænset af kapitalens valoriseringsmål, »i stedet for at produktionen skulle rette sig efter sociale behov, efter socialt udviklede menneskers behov«; der

54. K. Marx: Kapitalen, 1. bog 3, København 1971, s. 611.

55. ibid., s. 492.

56. ibid., s. 493 og s. 537.

57. K. Marx: Løn, pris og profit, op.cit., s. 434.

58a. Dunayevskaya fremhæver kampen om arbejdsdagen som et nyt element i planen for Kapitalen, som er et resultat af arbejdernes virkelige bevægelse. Det er muligvis korrekt, at det drejer sig om et element fra bogen om lønarbejdet, som blev optaget i Kapitalen - men dette sker uden at lønarbejdssiden underkastes samme logiske udvikling som kapitalsiden (R. Dunayevskaya: Marxism and Freedom, op.cit., s. 88-91).

58. K. Marx: Grundrids..., op.cit., s. 469.

59. M.A. Lebowitz: Capital and the Production of Needs, op.cit. 
findes altså kapitalistiske begrænsninger på behovstilfredsstillelsen ${ }^{60}$. Der er således en kløft mellem lønarbejderens faktiske samfundsmæssige behov og de behov som han normalt er i stand til at realisere (hans »nødvendige behov $\ll)$ :

De grænser, inden for hvilke det på markedet repræsenterede behov for varer efterspørgslen - er kvantitativ forskelligt fra det reale samfundsmassige behov, er naturligvis yderst forskellig for forskellige varers vedkommende; jeg mener hermed forskellen mellem det kvantum varer, der forlanges, og det kvantum, der ville forlanges med andre pengepriser på varen eller andre penge- eller livsforhold hos køberne ${ }^{61}$.

Og denne manglende evne til at realisere alle sine faktiske samfundsmæssige behov, til at sikre sig alle de brugsværdier, der medgår til opfyldelse af de opstillede mål, skaber utilfredshed... »så længe menneskets behov ikke tilfredsstilles, er det i konflikt med sine behov, og derfor også med sig selv $\ll^{62}$. Kampen for højere løn ligger således som noget iboende i lønarbejderen som værende-for-sig.

Som et resultat af denne undersøgelse af lønarbejdet har vi således klassekampen set i lønarbejder-perspektiv. Vi har ikke blot kapitalen for sig, men også lønarbejdet for sig; der er altså to »mål « - ikke blot kapitalens behov for valorisering, men også »arbejderens eget behov for udvikling «. Denne tosidede kamp, hvor hver af parterne forsøger at reducere den anden til afhængighed, kan man f.eks. iagttage i kampen om arbejdsdagens længde - hvor »magten træffer afgørelsen mellem lige rettigheder«; det samme gælder for kampen om lønnens størrelse:

(Profittens) faktiske grad bestemmes kun af den ustandselige kamp mellem kapital og arbejde; kapitalisten prøver stadig på at trykke lønnen ned til dens fysiske minimum og at udvide arbejdsdagen til dens fysiske maksimum, medens arbejderen stadig udøver et tryk i modsat retning. Problemet opløser sig i et spørgsmål om forholdet mellem de kæmpende kræfter ${ }^{63}$.

I første omgang har vi undersøgt lønarbejdet som dét, der står udenfor kapitalen; tilbage står at fuldende udviklingen af dets enhed med kapitalen. Lad os nu se nærmere på kapitalens produktionsproces og lønarbejdets produktionsproces. I første omgang er disse processer modsætninger.

60. K. Marx: Kapitalen 3. bog 2, København 1972, s. 340.

61. K. Marx: Kapitalen, 3. bog 1, op.cit., s. 244-245.

62. K. Marx: Notes on Adolph Wagner, op.cit., s. 191.

63. K. Marx: Kapitalen, 1. bog 2, s. 372; K. Marx: Løn, pris og profit, op.cit., s. 438-39. 
I den første konsumeres arbejdskraften af kapitalen, den eksisterer for kapitalen; i den anden konsumeres arbejdskraften af arbejderen selv og eksisterer for arbejderen. I den første besidder og dominerer produktionsmidlerne arbejderen; i den anden er det omvendt arbejderen, der besidder og dominerer dem. Forskellen kan således sammenfattet udtrykkes: arbejderen for kapitalen versus arbejderen for sig.

Videre udelukker disse processer hinanden. Arbejderen kan ikke på samme tid være for kapitalen og for sig. Jo længere tid arbejderen eksisterer for kapitalen, jo kortere tid har han for sig selv. Tilsvarende, jo større intensitet i hans arbejde for kapitalen, jo mere energi konsumeres af kapitalen, jo mindre energi har han for sig selv. Således er arbejde for kapitalen forskelligt fra arbejde for sig; det er arbejde, som er fremmedgjort fra sig. Arbejderen er kun for sig, når han ikke er arbejder for kapitalen.

Disse processer, som er modsætninger og gensidigt udelukker hinanden, er på den anden side også nødvendige for hinanden. Hvis arbejderen ikke producerer for kapitalen, kan han ikke producere for sig selv; hvis han ikke producerer for sig selv, er han ikke til rådighed for kapitalen. Hvis kapitalen ikke gennemløber sit kredsløb, kan arbejderen ikke gennemløbe sit; hvis arbejderen ikke gennemløber sit kredsløb, kan kapitalen ikke gennemløbe sit. Kapitalens reproduktion forudsætter lønarbejdets reproduktion som sådan; lønarbejdets reproduktion som sådan forudsætter kapitalens reproduktion. De to produktionsprocesser er hinandens forudsætning. De udgør således en enhed.

Vi har altså her en totalitet, hvor alle forudsætninger er resultater og alle resultater forudsætninger - enheden af kapital og lønarbejde, kapitalismen som helhed; der er tale om en enhed af modsætninger, hvis væsen er klassekamp. (Denne yderligere udvikling er fremstillet $\mathrm{i}$ Figur IV.)

Figur IV: Kapitalismen som en helhed som totalitet.

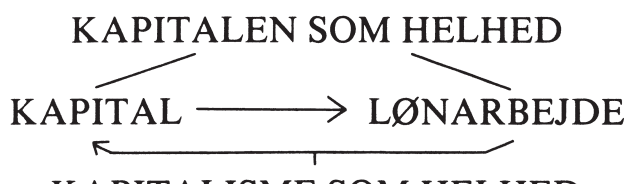

KAPITALISME SOM HELHED

(totalitet) 


\section{Kapitalens ensidighed ${ }^{64 a}$}

Kapitalen er ensidig - men ikke fordi den udelukker lønarbejdet som sådan. Det er klart, at lønarbejdet i sig ikke kan være fraværende fra Kapitalen vi kunne ikke engang tale om kapitalens udvikling uden lønarbejdet. Uden lønarbejdet som skranke ville der ikke være nogen grund til for kapitalen at skifte fra absolut merværdiproduktion til relativ merværdiproduktion, fra formel til real subsumtion af arbejdet; hvorfor skulle kapitalen indføre maskiner, øge kapitalens tekniske sammensætning, udvikle sin egen særlige produktionsmåde? Lønarbejdet er til stede som den skranke kapitalen overskrider. Det er imidlertid ikke tilstede som et mål, der har kapitalen som sin skranke; det er ikke til stede som lønarbejde for sig.

Selv der, hvor arbejdernes kampe fremhæves (som f.eks. i forbindelse med kampen om arbejdsdagen), er lønarbejds-sidens logiske forudsætning, lønarbejde for sig, fraværende. Det er kun med udviklingen af lønarbejdssiden, den side, der mangler i Kapitalen, at vi har et adækvat grundlag for i undersøgelsen af inddrage arbejdernes kampe for at realisere deres egne mål. Vi har nu den »indre totalitet«, kapitalismen som helhed, som ikke blot indeholder kapitalens mål, men også lønarbejdets - hvor lønarbejdets mål implicerer ikke-realiseringen af kapitalens mål, de peger i modsat retning ${ }^{64}$.

Vi kan ikke længere forudsætte at de »nødvendige behov«, eller de behov, der normalt opfyldes har et konstant omfang - altså den antagelse i Kapitalen, som skulle ophæves i bogen om lønarbejdet. Ikke når vi eksplicit har erkendt, at lønarbejdet har egne mål, når vi har set, hvorledes »arbejderen konstant kæmper i modsat retning « af kapitalens tryk og tendens; ikke når vi har sat arbejderens kamp for at reducere kløften mellem den eksisterende standard og deres faktiske samfundsmæssige behov - ligesom de udøver pres $i$ retning af at mindske arbejdsdagen.

De nødvendige behovs omfang viser sig tværtimod selv at være et produkt, et resultat - resultat af klassekamp. Dette er det historiske og moralske element i arbejdskraftens værdi. Bind I af Kapitalen, hvor begrebet om de nødvendige behov indføres som en forudsætning, som ikke forklares, for-

udsætter egentlig en undersøgelse af lønarbejdet-for-sig og af totalitetens

64a. Cleaver fremhæver korrekt nødvendigheden af at fokusere på den to-sidede klassekamp, men tager fejl, når han betragter den manglende forståelse herfor som et resultat af en fejlagtig læsning af Kapitalen i stedet for som et problem, der skyldes Kapitalens egen ensidighed. Tosidigheden er kun latent til stede i Kapitalen (ligesom kapital kun er latent til stede i varen), og for at forstå den adækvat kræves totalitetens fulde udvikling. Kort sagt, Cleaver overser de formidlende led, når han læser tosidigheden direkte ind i Kapitalen (H. Cleaver: Reading Capital Politically, op.cit.).

64. K. Marx: Grundrids..., s. 163. 
udvikling, kapitalismen som helhed, for at de nødvendige behov kan fremstå som resultater. I sig selv kan Kapitalen ikke logisk forklare omfanget af de nødvendige behov.

I sig selv fremstiller Kapitalen kun kapitalens tendenser og ikke lønarbejdets, kun kapitalens tryk for at øge merværdiraten og ikke lønarbejderens tryk for at sænke den. Først efter dens fuldendelse kan man iagttage selve totalitetens tendenser. Dette er én side af Kapitalens ensidighed. Der er imidlertid også en anden side. Vi kan nemlig ikke engang hævde, at Kapitalen har givet en adækvat fremstilling af denne ene side af totaliteten, kapitalen og dens tendenser.

Det er først indenfor den fuldendte totalitet, at kapitalen står overfor arbejdere, som kæmper for egne mål, arbejdere, som er mere end blot tekniske inputs, som man kan udnytte bedre, så de kan yde mere arbejde eller produceres billigere. Indenfor kapitalen som helhed stræber kapitalen ikke blot efter at realisere sine egne mål: den må også fors øge at hindre realiseringen af lønarbejdets mål. Den forsøger at »slå« arbejderne, at negere sin negation for at sætte sig selv.

Kort sagt, hvordan er det muligt at forstå kapitalens forsøg på at splitte lønarbejdet mod sig selv, at »slå« lønarbejdet, uden explicit at erkende arbejdernes mål og kampen for deres realisering? Disse handlinger fra kapitalens side har som deres forudsætning, at arbejderne har egne mål, at lønarbejdet eksisterer for sig.

Uden en korrekt forståelse af kapitalismen som totalitet må vort syn på kapitalens handlinger være ensidigt. Ikke alene forstår vi ikke lønarbejdets placering; vi forstår heller ikke kapitalen i dens relation til lønarbejdet. Der er således tale om en ufuldstændig forståelse af kapitalen. Først når vi har den fuldendte totalitet kan vi korrekt begribe forskellene indenfor enheden. Det vi præsenteres for i Kapitalen er blot et moment af kapitalen. Først når vi har den fuldendte totalitet kan vi korrekt begribe forskellene indenfor enheden. Det vi præsenteres for i Kapitalen er blot et moment af kapitalen i helhedens udvikling.

Indenfor totaliteten, kapitalismen som helhed, viser det sig eksplicit at kapitalen ikke blot stræber efter at udvide arbejdsdagen og $\emptyset$ ge produktiviteten, men også efter at svække arbejdernes stilling. Ændringer i produktionsmåden (kooperation, manufaktur, maskineri osv.) kan som umiddelbart mål have at hindre arbejderne i at realisere deres egne mål. Således er ansættelse af fremmedarbejdere fra forskellige etniske grupper med forskellige sprog mere end kooperation -det kan muligvis ovenikøbet sænke produktiviteten; på samme måde kan etableringen af et arbejderhierarki indenfor manufakturen betragtes som et fors $\emptyset \mathrm{g}$ på at reducere lønarbejdernes indbyrdes solidaritet. I kapitalens 
overvejelser om at erstatte direkte levende arbejde med maskineri indgår heller ikke blot en kalkulation, som sammenligner mængden af arbejdskraft med den mængde arbejde, som er indeholdt i maskineriet (således som det fremstilles i Kapitalens første bind) - disse overvejelser har også noget at gøre med behovet for at $»$ tilbagevise arbejdernes stigende $k r a v \ll{ }^{65}$.

Da det er valorisering (og ikke effektivitet som sådan), der er kapitalens mål, vil en given innovation blive indført, hvis den i tilstrækkelig grad hindrer arbejderne i at realisere deres mål, hvis den deler og splitter dem - også selv om den er mindre effektiv (i snæver teknisk forstand). I kapitalismen som helhed, i den adækvate totalitet, kan vi således ikke blot iagttage kapitalens iboende tendens til at udvikle produktivkræfterne, men også dens tendens til at splitte arbejderne ${ }^{66}$. Det er vigtigt at erkende dette som en kapital-iboende tendens, en tendens som udspringer af kapitalens valoriseringsmål indenfor totaliteten; hvis man betragter totaliteten som et reproduktionssystem, betyder dette altså at splittensen blandt arbejderne fremstår som et produkt og resultat - i stedet for som en tilfældig historisk forudsætning.

Hele denne side af kapitalen, som følger logisk, hvis man betragter kapitalen som et moment indenfor totaliteten, er gået tabt, fordi totaliteten aldrig er blevet fuldendt. Dette er, og må erkendes som, en mangel ved Kapitalen, et resultat af dens ensidighed. Bowles og Gintis placerer imidlertid årsagen til denne mangel i arbejdsværdilæren og i begrebet om arbejdskraften som en vare (og arbejdet som arbejdskraftens brugsværdi). De argumenterer korrekt for, at det er vigtigt at beskæftige sig med kapitalens fremgangsmåder ved udvindelse af merværdi, men fastslår derefter, at det er økonomisme « at tage udgangspunkt i eller lægge hovedvægten på arbejdsværdilæren:

Økonomismen reducerer den kapitalistiske produktion til at være bestemt af en begrænset - og indskrænket - del af de mange forskellige fremgangsmåder, som til sammen bestemmer akkumulationens dynamik ${ }^{67}$.

Hvem kan benægte denne karakteristik af økonomisme? Hvad skulle man ellers kalde en fremstilling af den teknologiske og produktivitetsmæssige udvikling, af udviklingen $\mathrm{i}$ arbejdsprocessen, arbejdernes dekvalificering osv., som ikke ser disse fænomener i sammenhæng med kapitalens kamp for at hindre realiseringen af arbejdernes mål? Hvor denne udvikling sker på

65. K. Marx: Kapitalen, 1. bog 3, op.cit., s. 628.

66. Vi er her helt enige med Bowles og Gintis, når de skriver, at »det er en nødvendighed at lagdele arbejdsstyrken for at mindske arbejdernes solidaritet«; vi ville imidlertid udtrykke det anderledes og sige, at »denne handling er en del af kapitalens væsen« (Bowles og Gintis: Structure and Practice..., op.cit., s. 15).

67. ibid., s. 1. 
grundlag af arbejderklassen i sig, men ikke for sig? Der er en klar tendens til at produktivkræfternes udvikling betragtes som en autonom proces; den teknologiske udvikling fremstår altså som »neutral « - dette er en nærliggende slutning, hvis man ikke ser på kapitalismen som helhed. Kort sagt: i Kapitalens ufuldendte fremstilling af kapitalen fremstår disse ændringer i arbejdsprocessen osv. ikke som resultater af klassekampen - som formede og strukturerede af klassekampens væsen (som kommer i fokus når man betragter kapitalismen som helhed som totalitet). I denne forstand er det korrekt at beskrive en sådan betragtningsmåde som »økonomistisk «.

Naturligvis må det samme gælde for lønarbejds-siden. Hvis man blot ser på lønarbejde-for-sig og på lønarbejdernes kampe for at realisere deres umiddelbare mål (dvs. løn, tid, kontrol med arbejdsprocessen osv.), har man endnu ikke adækvat placeret lønarbejdet indenfor totaliteten - som lønarbejde i relation til kapitalen. Der ville så ske en tilsløring af arbejdernes nødvendige kampe for at ophæve deres indbyrdes splittelse (for at konstituere sig som én) og splitte kapitalen mod sig selv - dvs. lønarbejdets kamp for at overvinde kapitalen, for at negere dens negation for at sætte sig selv. Og også dette er økonomisme. Kort sagt: når vi først har sat kapitalismen som helhed som den adækvate totalitet, en totalitet hvis væsen er klassekamp, vil det være ensidigt og økonomistisk ikke at unders $\varnothing g e$ kapitalens og lønarbejdets forskellige mål og praksisformer, dvs. de mål og praksisformer, som udspringer af deres interaktion.

Man kan således erklære sig enig med Bowles og Gintis i diagnosen Kapitalens utilstrækkelige forklaring af de reale fænomener og utilstrækkelige fremstilling af »den virkelige bevægelse«. Og dette er måske det væsentligste - på trods af de klart forskellige stier, der er fulgt. Alligevel kan den formelle lighed, hvad resultatet angår, ikke skjule den eklektiske kirurgi, Bowles og Gintis har udført på det legeme, de ønsker at redde. Når de foreslår at arbejdskraften ikke er en vare, er det så ikke blot en metafor, som skal fremhæve, at Marx ikke hævede sig over den politiske økonomi og ikke undersøgte arbejderen »når han ikke arbejder, når han er menneske «? Og videre, er det fremstillingen af arbejdet som arbejdskraftens brugsværdi, der berøver arbejdsværdilæren indsigt i, hvorledes der udpresses arbejde af arbejdskraften - eller det den manglende udvikling af et begreb om lønarbejdet for sig, den manglende erkendelse af »arbejderens eget behov for udvikling $\ll ?{ }^{68}$ Kort sagt, ville det ikke her være passende at benytte Occams ragekniv?

Styrken i Marx' dialektiske måde at tænke på er, at den frembringer en forståelse af helhedens nødvendige indre sammenhæng - i modsætning til 68. ibid., s. 17. 
den eklektisisme, som tager udgangspunkt i fremtrædelsesformerne og undlader at udvikle de formidlende led, og som er ude af stand til at bestemme noget som nødvendigt. Der er netop her blevet argumenteret for, at det var den manglende udvikling af lønarbejds-siden - som er latent til stede i Kapitalen - som har skabt en fejlagtig forståelse af helheden (og Kapitalens plads indenfor denne helhed). Kapitalen, altså bogen, må forstås i sin sammenhæng - i sin sammenhæng med bogen om lønarbejdet, som skulle fuldende »den indre totalitet «, i sin sammenhæng med bogen om staten, hvor der skulle ske en »koncentration af helheden«, og i sammenhæng med bogen om verdensmarkedet:

verdensmarkedet afslutningen, hvori produktionen er sat som totalitet, og ligeså ethvert af dens momenter; hvori imidlertid alle modsigelser samtidigt kommer i bevægelse. Verdensmarkedet danner så igen ligesåvel helhedens forudsætning som dens bærer ${ }^{69}$.

Fejlen har været, at man har ladet én bog stå for seks - en fejltagelse, som siger en hel del om forståelsen af Marx' metode. Det umiddelbare spørgsmål er imidlertid, om det er muligt at forstå kapitalismen som helhed uden at undersøge de »grundlæggende emner«, som skulle indgå i den manglende bog om lønarbejdet.

69. K. Marx: Grundrids..., op.cit., s. 163 og 129. 


\title{
Moderniseringspolitik som arena for arbejdspolitikken -
}

Jürgen Hoffmann

\author{
Overvejelser om en ny politiktypes \\ ambivalente funktioner. **
}

\section{Indledning}

»Moderniseringspolitik« har siden det dybe $\emptyset$ konomiske tilbageslag i midten af 70'erne gået for at være et politisk svar på den strukturelle krise i de nationale $\varnothing$ konomier og på verdensmarkedet.

Denne opfattelse har ikke blot været til stede i Forbundsrepublikken, men i næsten alle udviklede kapitalistiske industrinationer. Således ser de store fagforbund i Italien (særligt CGIL) en statslig fremskyndet modernisering af $\varnothing$ konomien som forudsætning for at overvinde Italiens rolle i de udviklede kapitalistiske landes periferi og dermed påny opnå et voksende materielt fordelingsspillerum. Under Mitterand's venstreregering i Frankrig fremf $\varnothing-$ res moderniseringspolitikken igen som den økonomiske politiks hovedlinie efter de første keynesianske ansatser. I forbundsrepublikken blev moderniseringspolitikken i hvert fald mellem 1974 og 1978 diskuteret som det politiske svar på de strukturelle problemer i økonomien og i al fald delvist omsat i politisk strategi i forsknings- og teknologiministeriernes regié.

I det følgende gælder det en analyse af det »moderniseringspolitiske« udkast, som det blev diskuteret i tilknytning til kriseårene 1974/75, og sådan som det endnu i dag (i det mindste ansatsvis) realiseres inden for teknologipolitikkens rammer. I denne analyse kan vi kun meget begrænset komme ind på det forhold, at de, der dengang promoverede diskussionerne i fagforbundene og partierne, har udbygget deres forslag siden 1977/78 (f.eks. med beskæftigelsesfremmende programmer). Disse udbyggende forslag kan i virkeligheden ikke unders $\varnothing$ ges som del af moderniseringspolitikken.

\footnotetext{
** Oversat fra Arbeitspolitik, Leviathan Sonderheft 5/83 af Peder Lærke Nielsen og Finn Hansson. Vi har valgt at oversætte 'Arbeitspolitik' med arbejdspolitik og ikke med arbejdsmarkedspolitik, da begrebet arbejdspolitik i vesttysk sammenhæng betegner en mere omfattende fors $\emptyset \mathrm{g}$ på statslig regulering af den samfundsmæssige produktion end det er tilfældet med begrebet arbejdsmarkedspolitik i dansk sammenhæng. oa.
} 
De må snarere forstås som en politisk konsekvens af de erfarede begrænsninger ved denne politiktype, hvis systematiske udfoldelse det her drejer sig om.

Moderniseringspolitik kan ikke blot begribes som en analog politiktype til »arbejdspolitik« (for en karakteristik af arbejdspolitikken sml. Jürgens'Naschold 1982, s. 328 f.), den rækker også langt ind i det arbejdspolitiske terrain og vil derfor i det følgende blive diskuteret som arbejdspolitikkens »arena $\aleph^{1}$ med støtte i Kitschelt (1980). Her bliver nemlig benævnt et »rum for politisk handlen«, hvori bestemte samfundsmæssige problemområder tematiseres og problemformulerings-, beslutnings- og gennemførelsesprocessernes bestemte strukturelle karakteristika og barrierer fremvises«. (Kitschelt 1980, s. 18).

På den ene side omfatter politiktypen »moderniseringspolitik «, analogt med »arbejdspolitik «, forskellige $\varnothing$ konomi- og samfundspolitiske områder ligeværdigt (virksomhed, branche, totaløkonomi, forsknings- og teknologipolitik og de tilsvarende områder for samfundsmæssig interesseartikulation og -interaktion). Dermed overvindes de keynesianske politikformer (og de neoklassiske, selv om de er anderledes skruet sammen), idet disse er makroøkonomisk og -samfundsmæssigt orienterede. For så vidt stiller sig altså det spørgsmål, som Jürgens/Naschold har udviklet med »arbejdspolitikken« som eksempel, nemlig hvorvidt denne politiktype står for en form for »statens udvidelse « (i tilknytning til indlægget fra Altvater/Kallscheuer 1979), hvilket falder sammen med spørgsmålet om de »klassiske mediers ('pengenes' og 'rettens') kompletering med et 'forhandlingssystem'.

Gennem analysen af moderniseringspolitikken skal vi i det følgende behandle dette spørgsmål, idet vi griber tilbage til den statsteoretiske diskussions resultater og deres (mulige) revision. ${ }^{2}$

På den anden side fastlægger moderniseringspolitikken arbejdspolitiske data på alle de områder, hvor de arbejdspolitiske strategier føres ud i livet (netop fordi den samtidig relaterer sig til det mikroøkonomiske område). På en vis

1. Arena-begrebet kan ikke fremstilles på en teoretisk tilfredsstillende måde her, se fremstillingerne hos Kitschelt (1980) som bygger på Lowi (1964). Det vigtigste for den følgende fremstilling er den fordel, som arena-begrebet har, for så vidt at forholdet mellem $\emptyset$ konomi (samfund) og politik trækkes frem og tematiseres omkring problemer. De politikinterne problemformulerings- og forarbejdningsstrukturer- og processer kan der ikke tages hensyn til i det følgende.

2. Jeg forholder mig her især til de statsteoretiske bidrag fra Blanke m.fl. (1975) og Blanke (1977). 
måde gennemtrænges denne type politik (»moderniseringspolitik «) af arbejdspolitisk relevante akkumulations-vog legitimationsimperativer forstået som politikkens funktionale problemer og tilsvarende problemløsningsstrategier.

Alment tilkommer der den $\varnothing$ konomiske politik og socialpolitikken en større betydning inden for »arbejdspolitikkens « rammer, fordi

- der over den (formodede »politisk frembringelige«) vækst kan etableres et totaløkonomisk og brancherelateret fordelingsspillerum og dermed også - handlingsspillerum i relation til arbejdsbetingelsernes udformning, mulighederne for medbestemmelse på virksomhedsniveau, kontrollen med virksomheds- og branchemæssige omstruktureringer, således at der etableres og/eller udvides

- muligheder for financielt at underbygge sikringen af arbejdskraftens reproduktion - enten »præventivt« eller i form af »reparation « (ligemeget om dette sker formidlet over den statslige socialpolitik eller gennem den fagforeningsmæssige eller virksomhedsnære interesserepræsentation).

Lykkes en sådan politik, må den nødvendigvis styrke den samfundsmæssige konsensus (»tro på systemet«), da den på én gang tager de lønafhængiges og kapitalbesiddernes interesser i betragtning (og må tage dem i betragtning) og udvider fordelings- og handlingsspillerummet gennem det indirekte krav om vækst og produktivitet. (Omvendt kan man ikke i de politikvidenskabelige legitimations(-krise-) teoriers forstand slutte, at denne politiks sammenbrud straks og tvangsmæssigt vil føre til legitimatoriske systemproblemer.) Den systematiske mulighed for, at denne politik bryder sammen ikke blot af politik-immanente, men af systembetingede grunde, kan her fastholdes og forudsættes på baggrund af den nyere (marxistiske) statsdiskussions resultater (sml. her Blanke m.fl. 1975, Blanke 1977 og Brandes m.fl. 1977). Denne diskussion refererede sig til statens system- og handlingsgrænser i relation til reguleringen af samfundet ved hjælp af medierne 'ret' og 'penge'. Analysen af moderniseringspolitikken som en politiktype, der overskrider de klassiske interventionspolitikker, rejser netop spørgsmålet om, hvorvidt moderniseringspolitikken kan begribes som en udvidelse af staten og dermed politikkens muligheder for at regulere samfundsmæssige processer. Kort sagt: betyder statens udvidelse samtidig en udvidelse af mulighederne for den statslige reguleringskapacitet?

Eller vi kan i forlængelse af statsdiskussionens problemstillinger formulere spørgsmålene: 
1. De klassiske interventionspolitikkers systemgranse var et resultat af samfundets (private) reproduktionsstruktur. Vil det lykkes at ændre disse strukturer ved hjælp af denne nye politiktype?

2. Manglerne ved de klassiske medier 'ret' og 'penge' følger af deres anknytning til kapitalreproduktionens funktionelle former. Vil det med den nye politiktypes hjælp lykkes at finde eller frembringe et nyt og mindre modsætningsfyldt anknytningspunkt?

3. Den klassiske interventionspolitiks handlingsgranser var i hovedsagen sat gennem de førpolitisk fastlagte kompromislinier i samfundet (f.eks. mellem overenskomstparterne). Vil det lykkes at udvide disse grænser gennem en udvidelse h.h.v. kompletering af de klassiske medier med »forhandlingssystemer $\ll$ ?

\section{Moderniseringspolitikken i sin historiske sammenhæng.}

Moderniseringspolitik kan forstås som det politiske systems reaktion på det $\emptyset$ konomiske og samfundsmæssige strukturbrud i de kapitalistiske samfunds udvikling i midten af 70erne. Dette strukturbrud, som i alle udviklede kapitalistiske samfund finder udtryk i overcyklisk inflation, $\varnothing$ konomisk stagnation og fremvæksten af massearbejdsløshed, formidler politikken først og fremmest ved, at de klassiske interventionspolitikker afsværges (således er f.eks. stagflationen en skranke for den fortsatte anvendelse af keynesiansk efterspørgselspolitik). Nye politikformer skal altså forbedre eller erstatte de gamle former.

Strukturbruddet er uden tvivl først og fremmest af økonomisk natur. Til forskel fra mellemstore cykliske kriser, der kan formidles politisk inden for en efterspørgsels- og/eller udbudsorienteret konjunkturpolitik (om end ikke dog ikke dermed styres), så kræver strukturbrud i den langsigtede udvikling åbenbart nye politikformer (sml. Altvater 1982). Dette gælder i særlig grad for den (arbejdspolitisk relevante) $\varnothing$ konomiske politik og socialpolitikken. For socialpolitikken mest på den måde, at der først og fremmest pga. faldende bidrag til socialforsikringen samt forringet skatteprovenu samtidig med voksende krav (til ydelser) kan gennemføres spareforanstaltninger, som pga. den vedvarende $\varnothing$ konomiske stagnation går ud over de oprindelige sammenhænge og integreres i nye (eller rettere gamle!) samfundspolitiske begrundelser. På denne måde kan der tales (og handles) om »omlæggelse« fremfor »nedlæggelse« af velfærdsstaten (jvf. Altvater 1982).

For den $\emptyset$ konomiske politik kommer strukturbruddet til udtryk deri, at endog $»$ verdens mest moderne instrumentarium for $\varnothing$ konomisk politik« (Ehrenberg) 
ikke længere slår til. Den keynesianske efterspørgselspolitik blev pga. den ledsagende priseffekt og udeblivende mængdeeffekt begrebet som utilstrækkelig overfor de nye økonomiske problemer og skulle derfor kompleteres eller erstattes med aktive strukturpolitiske foranstaltninger, dvs. med $»$ moderniseringspolitik $\ll^{3}$.

Den keynesianske politik til regulering af de nationaløkonomiske makrostrømme var den økonomiske politiks reaktion på den økonomiske (og finanspolitiske) instabilitet i midten af 60'erne. Det var ikke et strukturbrud, som var anledning til at kodifisere keynesianske politikformer i stabilitetsog vækstlove flankeret af installeringen af den »Konzertierten Aktion $\aleph^{3 a}$ men de cykliske krisers genopdukken i efterkrigstiden med cyklisk arbejdsløshed (som i 1966/67) begrundet i en utilstrækkelig vækstimpuls, samt kapitalakkumulationens strukturelle forandringer (jvf. Altvater m.fl. 1979). Politikken selv blev altså her »moderniseret«. I vores temasammenhæng er der to implicitte forhold ved den keynesianske reguleringspolitik, som den blev kodificeret i 1967 og praktiseret frem til 1973, der har betydning:

1. Denne keynesianske reguleringspolitik knytter an til de givne $\varnothing$ konomiske og samfundsmæssige strukturer og forsøger at stabilisere og dermed opretholde disse gennem finans- og indkomstpolitiske påvirkninger af nationaløkonomiens makrostørrelser (»Globalsteuerung « eller helhedsstyring) (sml. her Bolle 1977, Hoffmann 1977). Kriseagtige sammenbrud, som udløser eller medfører strukturforandringer, skulle på forhånd forhindres.

2. Idet den keynesianske reguleringspolitik opretholder og stabiliserer de givne strukturer, stabiliserer den også den dermed forbundne samfundsmæssige konsensus. Ikke gennem omfordeling, men gennem en udvidelse af fordelingsspillerummet via en garanteret $\varnothing$ konomisk vækst skal »konsensusdannelsen gennem interesseinteraktion « fremmes (sml. Blanke 1977)! Målet er, gennem holdningsstyring af de økonomiske subjekter, at få »realindkomsten for denne og hin gruppe til at stige uden at tage noget fra nogen.«(Schiller 1968, s. 72).

3. Under moderniseringspolitik sammenfattes i det følgende diskussioner, som også har været kaldt »selektiv investeringsfremme«, »aktiv strukturpolitik« eller blot »strukturpolitik « i socialdemokratiet og fagbevægelsen. Det drejer sig ikke om den konkrete udformning af denne diskussion men om en ny politiktype. Dette skal dog ikke hindre, at der gribes illustrativt tilbage til brudstykker af disse diskussioner.

3a. 'Konzertierte Aktion' betegner en vesttysk indkomstpolitisk aftale mellem fagbevægelse, stat og arbejdsgivere. 
Denne reguleringspolitik bevarede sin kapitalfunktionalitet så længe strukturændringerne fra krisen 1966/67 fortsat havde positiv virkning og så længe dén samfundsmæssige konstellation, der var institutionaliseret i den »Konzertierten Aktion«, blev opretholdt. De økonomiske og samfundsmæssige strukturer rummede stadig et stort potentielt produktivitets- og rentabilitetsspillerum. Efterhånden som disse akkumulationsbetingelser blev undergravet i den $\varnothing$ konomiske cyklus, og indkomstpolitikken brød sammen mellem 1970 og 1972 som følge af den fulde beskæftigelse, blev de politiske garantier for opretholdelsen af de givne samfundsmæssige strukturer (dvs. den fulde beskæftigelse) kapitalistisk set disfunktionel. Lurende værdiforringelse, restruktureringer og lønsænkninger blev forhindret eller udskudt på bekostning af en stigende inflationsrate. Den her fremlagte forståelse (for en mere udførlig redegørelse sml. Altvater m.fl. 1979, 2. og 3. del) må imidlertid ikke tolkes i betydningen en »political-business-cycle « ${ }^{4}$ ! Når arbejdsgivernes autonomi og fagforeningernes overenskomst-autonomi er givet på forhånd, resulterer den politiske regulering af efterspørgselsniveauet under et cyklisk tilbageslag i en inflationært formidlet udskydelse af værdiforringelsesprocesserne, som så sætter sig igennem i krisen 1974/75. Denne udvikling er ikke udtryk for en forskydning af de politiske magtforhold bag den $\varnothing$ konomiske politik, som så bevidst angriber krisen med stabilitets- og højrentepolitik.

Det politiske omsving, skiftet væk fra den keynesianske niveauregulering, er tvært imod et resultat af de erfarede skranker ved reguleringspolitikken. Altså at investeringsbeslutninger ud fra rentabilitetsberegninger har primat (i systemgrænsens betydning), og at det er nødvendigt for fagforeningerne at udnytte deres magt på markedet $\mathrm{i}$ boomfasen, hvis de ikke er indstillet på at tage delegitimerende processer i de faglige organisationer med i købet (aktivitetsgrænsernes område).

Med den (foreløbige) afslutning på den keynesianske efterspørgelsregulerings primat skete der også et sammenbrud i det klassekompromis institutionaliseret i den »konzertierten Aktion « - som stod bag denne politik og som blev stabiliseret gennem den (sml. BuciGlucksmann 1982, Hoffmann 1982). De da institutionaliserede korporatistiske strukturer

4. Ifølge Kalecki (1943) gøres især kapitalens omsving (især den rentebærende kapital) og centralbanken ansvarlig for konjunkturcyklus'en under keynesiansk økonomisk politik. Med fuld beskæftigelse trues pengeværdien af lønstigninger og disciplinen i fabrikkerne svigter osv., og kapital og centralbank vender sig af denne grund mod et yderligere samarbejde med den keynesianske $\emptyset$ konomiske politik og satser igen på krisens disciplinerende kraft. Kritik heraf findes $\mathrm{i}$ Hoffmann 1978. 
blev $\varnothing$ delagte gennem krisen og den efterfølgende stagnationsfase, ikke mindst fordi kapitalsiden i stadigt mindre omfang indlod sig på korporatistiske arrangementer og i stigende grad satsede på disciplineringselementet i de markedskræfter, der var gunstige for den. Den (ny-) komservative teori om økonomi og samfund, som nu sætter sig igennem (omend delvis bremset af socialdemokratiet), og som også har indflydelse på den praktiske $\varnothing$ konomiske politik (sml. Hoffmann 1982), kræver ligefrem, at de korporative arrangementer afvikles og bandlyses til fordel for markedet og de retningslinier for adfærd, som dets tilstand dikterer. ${ }^{5}$ Kompromislinien mellem kapital og lønarbejde bliver nu også i praksis rykket pga. massearbejdsløshed, inflation, arbejdsmarkedets segmentering og i reglen forskudt til kapitalens fordel.

\section{Moderniseringspolitik som svar på det økonomiske og samfundsmæssige strukturbrud.}

Det omtalte $\varnothing$ konomiske og i sine følger også samfundsmæssige strukturbrud er siden midten af 70'erne tydeligst kommet til udtryk i den (meget analyserede) »frakobling « mellem $\varnothing$ konomisk vækst og produktivitetsvækst. Alene en forceret akkumulation ville have kunnet sikre en høj overcyklisk beskæftigelsesgrad; men betingelserne herfor eksisterer ikke mere pga. såvel interne som eksterne forandringer. Arbejdsgiverne reagerede på kapitalrentabilitetskrisen i og efter krisen 1974/75 med en massiv teknologisk forvandling og fornyelse af produktionsapparatet uden dog at udvide det i nævneværdig grad. På hjemmemarkedet stødte produktivitetsstigningen således på en lav efterspørgselstilvækst (dette gælder også for Sektor I, »produktionsmiddelproduktion «). Samtidig blev eksporten allerede fra begyndelsen af 70'erne begrænset, dels pga. den forandring $\mathrm{i} » d e n$ internationale arbejdsdeling «, som også gjorde sig gældende allerede fra 70'ernes begyndelse (jvf. her Fröbel m.fl. 1977), dels som følge af den generelt stagnerende efterspørgsel på verdensmarkedet og den skærpede konkurrence mellem de udviklede kapitalistiske industrinationer (Japan-USA-Vesteuropa) siden verdensmarkedskrisen i 1975.

5. Den »korporatisme-diskussion«, som allerede i 1974 blev moderne i Vesttyskland, har efter min mening overvurderet interesseformidlingsformerne og dermed blokeret for en indsigt i disse historiske og strukturelle skranker for en videre udvikling af korporativistiske strukturer. Ikke mindst gælder det, at den ofte fremstillede nærmest tvangsmæssige udvikling mod »stadig mere « korporatisme gennem den nyeste tids hændelser i USA og England (men også i Vesttyskland efter den »konzertierte aktion «s forlis) nærmest er blevet vendt om. 
Da reguleringen af efterspørgselsniveauet gennem den statslige $\varnothing$ konomiske politik under disse forudsætninger kun havde priseffekter, men ingen mængdeeffekter, søgte den $\varnothing$ konomiske politik efter krisen 1974/75 hovedsagelig sin frelse i en »udbudsorientering «, dvs. i en begunstigelse af profitproduktionen (hvor det for vores problemstilling er af underordnet betydning om dette sker gennem højrekeynesianske foranstaltninger eller gennem neoklassiske politikvarianter), og i sektoralt rettede investeringsfremmeprogrammer (jvf. således fremtidsinvesteringsprogrammet' - ZIP -)..$^{5 a}$

I denne sammenhæng er dé forskellige varianter af »moderniseringspolitikken «, som er blevet lanceret siden 1975, først og fremmest at betragte som udbudsorienteret $\varnothing$ konomisk politik. Som den blev diskuteret inden for det da (endnu regerende) socialdemokratis horisont, blev denne politik ikke forstået som modsætningen til en keynesiansk efterspørgselspolitik, men som en udfyldning eller overvindelse af efterspørgselspolitikkens mangler, af dens »naivitet « $\mathrm{i}$ forhold til de nødvendige strukturelle forandringer i produktionsapparatet. Peter Kalmbach har i tilknytning til den (socialdemokratiske) diskussion efter 1975 sammenfattet den $\varnothing$ konomiske politiks mål med moderniseringspolitikken på følgende måde:

»'Økonomiens modernisering' har i det mindste to formål for øje: For det første en ændring af produktionsstrukturen - især fremmet gennem teknologipolitik -. Forbundsrepublikkens chance anses, især i den internationale konkurrencedueligheds perspektiv, for at ligge inden for de såkaldet 'intelligente produkters' område. Udviklingen af en hertil svarende produktionsstruktur synes at være den afgørende forudsætning for sikringen af beskæftigelsen allerede på middellangt sigte. For det andet skal de teknologisk mest udviklede produktionsmetoder bringes i anvendelse, igen understøttet af en teknologipolitik. Dette bidrag til beskæftigelsessikring består altså ikke i en begrænsning af produktionsfremskridtene, men tvært imod gennem at forcere disse.« (Kalmbach 1987, s. 398).

En sådan opfattelse af moderniseringspolitikken bygger på 'indsigt i nødvendigheden' af, at den traditionelle vakstrelaterede samfundsmassige

5a. Allerede gennem deres meget sektorprægede udformning adskiller beskæftigelsesprogrammerne efter 1974 sig fra den tidligere gennemførte politik. Efter min mening skal resultatet af de gennemførte programmer ikke overvurderes (som DIW-Berlin eksempelvis fremstiller dem), da disse programmer fungerer i en opsvingsfase og -overcyklisk betragtet - næppe kan tjene som bevis for rigtigheden i kravet om genoptagelse af en forceret efterspørgselspolitik. Jvf. hertil diskussionen om Memorandapositionen i Altvater m.fl. 1979, s. 382 ff. 
konsensus må restabiliseres i en situation, hvor den synes truet af en negativ vækstrate og massearbejdsløshed. Truet i særlig grad (ifølge denne moderniseringspolitikdiskussion) er arbejderklassens kerne, de faglærte. For dem gælder det, at deres arbejdspladser ikke blot skal sikres gennem moderniseringspolitikken. Inden for denne politiks rammer skal deres kvalifikationer endvidere udnyttes bevidst som en konkurrencefordel. (sml. her Hauff/ Scharpf 1975, s. 118, Scharpf 1974, s. 17 og 21).

Årsagen hertil er, at den vesttyske kapitals stærke stilling på verdensmarkedet anses for at være begrundet $\mathrm{i}$ anvendelsen af højt kvalificeret arbejde, særligt ved produktionen af »intelligente « produkter i produktionsmiddelindustrien, som udgør den største andel af eksportprodukterne. De faglærte arbejdere, denne kerne, som samtidig har en høj faglig organisationsgrad, er imidlertid ikke blot den tyske eksportindustris »vigtigste industrielle råstof «(Hauff/-Scharpf), men udgør sammen med kapitalens vækstsektorer kernen i, hvad den seneste politik- og socialvidenskabelige diskussion har sammenfattet til »Modell Deutschland « (sml. her Esser m.fl. 1980).

I de kvalificerede lag i arbejderklassen mødes således den samfundsmæssige udviklings akkumulations- og legitimationspotentiale i skøn forening. En konstellation, som under den socialdemokratiske regeringsdeltagelse yderligere blev forstærket, og som samtidig kan gælde som fundament for den socialdemokratiske »model «. Ideen med Moderniseringspolitikken skulle bruges til en dynamisk stabilisering af denne »Modell Deutschland «, men ikke mindst skulle modellens dynamiske fundament - forbundet mellem vækstkapitalen og den kvalificerede arbejdskraft - opretholdes og udnyttes som en konkurrencefordel på verdensmarkedet. ${ }^{6}$

Når denne forestilling om en moderniseringspolitik i det følgende bliver undersøgt i perspektivet af de i indledningen nævnte problemstillinger, så er det ikke fordi den allerede er blevet almindelig praksis i den $\emptyset$ konomiske politik. Tvært imod blev det stort set ved teorien, også under den socialliberale koalision (hvor en af moderniseringspolitikkens forkæmpere, Volker Hauff, periodevis ledede forskningsog teknologiministeriet). Kun på kerneteknologiens område og til fremme af halvlederteknologien blev

6. Til diskussionen af »Model Deutschalnd « som en historisk-specifik udviklingstype for udviklede kapitalistiske samfund se temanummer Prokla 40 (1980), især bidraget fra Hirsch/Roth, Esser m.fl. 
elementer fra denne tankekonstruktion omsat i praktisk politik. ${ }^{7}$ Det, det først og fremmest drejer sig om her, er diskussionen af en ny politiktype og hermed spørgsmålet, om denne politiktype i noget afgørende omfang »udvider« politikkens muligheder (sådan som det påstås).

\section{Ambivalente funktioner med basis i modsigelsesfyldte strukturer - Kritik af moderniseringsplanen.}

Lad os først endnu engang fastslå, hvilke nye elementer der ligger i moderniseringspolitikken i forhold til den keynesianske reguleringspolitik:

a) Ændringen af den $\varnothing$ konomiske struktur understøttes af en målrettet politik, dvs. teknologipolitik og direkte fremme af teknologiske innovationer og vækstindustrier. Økonomiske (og som det vil vise sig også samfundsmæssige) strukturer skal ikke opretholdes, stabiliseres, men forandres med det formål at øge konkurrenceevnen på verdensmarkedet.

b) Dette betyder igen, at den keynesianske niveaustyrings makroorientering opgives til fordel for en intervention på Meso-(branche-) og mikro(virksomheds-) niveau for herved at ændre konkurrencebetingelserne positivt (for så vidt angår vækstindustrien) og negativt (for så vidt angår brancher og virksomheder i tilbagegang).

Ledelses- og overenskomstautonomien forbliver imidlertid en forudsætning og dermed hin systemgrænse for politisk regulering, hvis betydning for helhedsstyringens sammenbrud vi allerede har fremført. Når denne grænse er givet, må spørgsmålet således blive, om den nye moderniseringspolitik gennem sin form og gennem mediet »forhandlingssystem « i noget væsentligt omfang udvider statens handlingsspillerum (i samme betydning, som tesen om den »udvidede stat «)?

Lad os straks gøre op med en mulig misforståelse her. Moderniseringspolitikken i den ovenfor skitserede betydning har ikke til hensigt at ændre $\varnothing$ konomiens retning efter politiske kriterier. Tvært imod stiller den sig i det store og hele kun som opgave at initiere en $\emptyset$ get akkumulation. Hertil skal enkeltvirksomhedernes nødvendigvis bornerte planlægning overskrides, og der skal etableres en mellemfristet prognostisering over forandringer i de

7. Kitschelt (1980) kan med forbundsregeringens fremme af kerneenergi som eksempel vise, at moderniseringspolitik som »aktiv strukturpolitik « allerede fra 1962 er blevet virkeliggjort i denne sektor. 
$\varnothing$ konomiske strukturer i indland og på verdensmarkedet for på dette grundlag at opbygge en målrettet fremme af teknologier og industrier. For så vidt er denne moderniseringspolitik markedsformidlet, idet den bevidst griber (og foregriber) de »restruktureringsprocesser«, der sætter sig igennem over markedet, med den hensigt at forberede dem i forskningspolitikken og fremskynde dem i teknologipolitikken. ${ }^{8}$

Den kapitalistiske krises funktion i kapitalens reproduktionsproces består $\mathrm{i}$ at genfrembringe reproduktionens proportionale betingelser og at $\emptyset \mathrm{ge}$ arbejdets produktivkraft gennem nyanlæg af en revolutioneret teknologi som produktiv kapital. Denne funktion udvikles i moderniseringsplanen til at begrunde en selektiv investeringsst $\varnothing$ tte. Krisen bliver altså begrebet som en chance for politikken. En politik, der således med hjælp fra den krisefyldte restrukturering fremmer struktursaneringen og dermed den generelle produktivitetsudvikling ved på den ene side bevidst at underst $\varnothing$ tte moderniserings- ( $=$ restrukturerings-) processer, men på den anden side også ved (og særligt i Hauff/Scharpf's udkast promoveres dette offensivt) at afholde sig fra at støtte konkur-

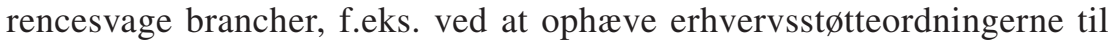
disse.

Den uoverskridelige systemskranke, som arbejdsgiverautonomien sætter, betyder, at også det moderniseringspolitiske udkast må knytte an til kapitalkredsløbets funktionelle former. Mens den keynesianske reguleringspolitik lagde hovedvægten på varekapitalens kredsløb og her nødvendigvis måtte begrænse sig til en makroøkonomisk niveaustyring, så lægger moderniseringspolitikken hovedvægten på en anknytning til den produktive kapitals kredsløb. For at opnå dette, er det imidlertid nødvendigt at forlade det nationaløkonomiske makroniveau og i stedet intervenere på brancheog enkeltvirksomhedsniveau. Denne intervention sigter imidlertid ikke på at andre totalreproduktionsprocessens økonomiske strukturer, men på at effektivisere de stoflige strukturer for herved at fremskynde kapitalakkumulationen.

Den kapitalistiske reproduktionsproces' strukturer er imidlertid nødvendigvis modsigelsesfyldte pga. den privat-decentrale produktionsmåde.

8. Målet med denne »fremskyndelse« rummer, at politikken også her kun kan give indirekte tilskyndelser til kapitalen i form af tilbud; i hvilket omfang disse tilbud (i form af samarbejde om forskning, udvikling og indsats af ny teknologi) modtages er kapitalens afgørelse. 
Denne modsigelsesfyldthed finder en midlertidig løsning i krisen. Moderniseringspolitikkens funktion er derfor ambivalent ${ }^{9}$, netop fordi den relaterer sig til den kapitalistiske reproduktions modsigelsesfyldte strukturer uden at ændre dem. Denne tese skal i det følgende begrundes nærmere på to punkter. (1) Tesen om, at man gennem moderniseringspolitikken kan sikre og fremskaffe arbejdspladser skal undersøges henover den stoflige struktur og de sociale følger af den nye teknologi, som skal indføres, og (2) moderniseringspolitikkens legitimatoriske funktioner skal diskuteres.

\section{Moderniseringspolitikkens ambivalens (I): Den kapitalistiske teknologianvendelse og dens sociale følger.}

Socialdemokratiets udgangspunkt i diskussionen om moderniseringspolitikken var massearbejdsløshedens mulige deligitimerende følger, især når også arbejderklassens kerne, de faglærte, var truet. På den anden side blev netop disse faglærte arbejderes kvalifikationer betegnet som forbundsrepublikkens »vigtigste råstof «. I disse mål og forudsætninger for moderniseringspolitikken er indeholdt to hypoteser: (1) Kernearbejdskraften kan beskæftigelsespolitisk sikres, og beskæftigelsesproblemet overhovedet langsigtet løses gennem erhvervslivets modernisering. (2) Moderniseringspolitikken aktiverer produktivitetsressourcer, der netop er indeholdt i denne kerne i form af kvalifikationer.

For at afprøve disse hypoteser, må vi undersøge restruktureringsprocessens resultat nøjere. Moderniseringspolitikken forstår sig selv - og heri følger

9. Jeg anvender her bevidst begrebet »ambivalensfunktionalisme« som Bernhard Blanke har udviklet i en kritik af Niklas Luhmann og tilsvarende af Claus Offes kritik af Luhmann. Denne sammenhæng skal her citeres udførligere:

»Den sammen funktion (i betydningen problemløsning) kan altså ikke som hos Luhmann opfyldes af forskellige strukturer og processer, som er vilkårlige og komplementcere (dvs. således også overhistorisk sammenlignelige), men den samme funktion vil på sin side være bestemt af forskellige forhold, som ikke er komplementære men modsigelsesfyldte og ikke vilkårlige men historisk bestemte (dvs. heller ikke ahistorisk sammenlignelige). Disse modsigelsesfyldte historisk bestemte forhold gør funktionsudfyldelsens proces og struktur ambivalent. Ambivalensen er udtryk for den historisk-specifikke form for materiel livsproces bestående af en totalitet, der reproducerer sig gennem selvstændiggjorte »områder«. (Blanke 1976, s. 195)

Selv når det specifikke ved (den økonomiske) krise netop ligger $i$, at alle selvstændiggjorte momenter i den materielle reproduktionsproces kriseagtigt bringes sammen igen, så forbliver funktionen af en politik, som i sine relationer er tilvejebragt som en funktion af krisen (hvilket er hvad moderniseringspolitikken forsøger) fanget i denne ambivalens, som det skal vises i den følgende fremstilling. 
den den socialdemokratiske reformpolitiks tradition - som en politik, der vil overvinde de samfundsmæssige hhv. økonomiske »flaskehalse « i Forbundsrepublikkens udvikling. I det følgende behandler vi tre eksempler på sådanne »flaskehalse«, som - som det hurtigt skulle vise sig - blev anledning til moderniseringspolitikken i reproduktionsprocessens stoflige struktur.

\section{Nye teknologier i produktionsprocessen.}

Statslig fremme af forskning og udvikling på halvlederteknologiens område anses for at være en central løftestang for at befordre den tyske kapitals konkurrencestilling på verdensmarkedet. Denne nye teknologi, hvis anvendelse i produktionsprocessen kun er i sin begyndelse, bliver især anvendt til automatisering hhv. delautomatisering af processtyringsaktiviteter i produktionen og - i forbindelse med den nye kommunikationsteknologi - til rationalisering af administrationsaktiviteter. Indførelsen af sådanne nye teknologier forudsætter en kvalificeret stamme af faglærte arbejdere, især i innovations- og indkøringsfasen. På den anden side rettes indførelsen af disse teknologier (hvad der især er tydeligt på styringsprocessernes område) mod det relativt høje lønomkostningsniveau, som er forbundet med de faglærte i produktionen og funktionærerne i administrationen. ${ }^{10}$ Selv om der således måtte være forbundet et højere fagligt kvalifikationsniveau med indførelsen af disse teknologier, så medfører de rent kvantitativt en reduktion og opsplitning i de faglærtes funktionsområde og en fortsat differentiering af samme. ${ }^{11}$

Allerede dette kvantitative aspekt, som ofte overses i de industrisociologiske undersøgelser, turde blive af betydning i de kommende årtier. De omtalte nye teknologier sigter i reglen mod en forøgelse af produktivkraften, uden at der indgår nogen beskæftigelseseffekt. I en af Kalmbach (1978) citeret

10. Dette mål er her kun udviklet meget sammentrængt. For den enkelte virksomhedsejer udtrykker rationaliseringsprocessen sig i det mål at spare omkostninger gennem udvikling af produktivitet og $\varnothing$ konomisering med den konstante kapital. Disse bestræbelser fører imidlertid til erstatning af arbejdskraft med maskineri (»rationaliserende innovation«), en modsigelse, der bl.a. er begrundet i moderniseringspolitikkens ambivalente problemløsning.

11. Tendenserne i den nye teknologis virkning er meget omstridte i industrisociologien (jvf. den aktuelle kontrovers på sociologikongressen om Kern/Schumanns indlæg (1982), og det vil sikkert være overdrevet (og også meget »umarxistisk «!) at konstruere en retlinjet udviklet i retning af dekvalificering, arbejdsløshed, elendiggørelse. De foreliggende studier (f.eks. Mackler 1981, Baethge 1982, arbejderne fra IFS-Ffm) ser imidlertid ikke kun ud til at pege på en yderligere differentiering og polarisering, men også på en åbning af mange fagarbejderfunktioner for tayloriserende omstillinger og kvantitativ overgang til dekvalifikation som følge af indsats af ny teknologi i produktions- og tjenesteydelsessektorerne. 
empirisk undersøgelse fra Ifo-instituttet fastslås det, at det overvejende flertal af de undersøgte teknologier bringer en betydelig mulighed for at spare arbejdspladser med sig, hvorfor rationalet i deres anvendelse er en »rationaliserende innovation « (Kalmbach 1978, s. 397) ${ }^{12}$

Det er ikke kun fagarbejderens kvalifikationer og arbejdsplads, som trues af den nye teknologi. Hans dispositions- eller handlingsspillerum indsnævres, idet hidtidige rene fagarbejderfunktioner med omfattende handlingsspillerum til dels åbnes for taylorisering gennem indsats af ny teknologi. Her forekommer et aspekt, som Shaiken (1980) har fremhævet vigtigt: I forbindelse med ny kommunikationsteknologi kan disse omvæltningsprocesser i produktionen føre til en forstærket ydre kontrol med fagarbejderne fra det tekniske managements side, helt frem til en gennemsættelse af herredømmet i virksomheden gennem kontrol med fagarbejderens arbejdsplads og arbejdsforløb.

De tendenser, der aftegner sig, tillader i al fald den konklusion, at arbejderklassens kerne, som moderniseringspolitikkens resultater skulle anerkende og beskytte, bliver ødelagt henholdsvis »undermineret« af den indsatte teknologis virkning inden for de enkelte virksomheder. Netop fordi virksomhedsledelsens autonomi i det store og hele er forudsat, kan en moderniseringspolitik kun virke inden for de rammer, som virksomhedernes rentabilitetskalkuler sætter. Den vil da overhovedet heller ikke abstrahere fra denne målsætning, men - med et blik på verdensmarkedskonkurrencen - gøre virksomhederne i stand til på mellemlangt sigt igen at finde en kalkulation, der både muliggør en øget rentabilitet og forbedrede konkurrencebetingelser på verdensmarkedet.

Anvendelsen af den moderne teknologi til at $\emptyset \mathrm{ge}$ arbejdets produktivkraft fører således ikke til en sikring af den faglærte arbejders sociale position (eller til arbejderens i det hele taget). Tvært imod fører den til overflødiggørelse af arbejdskraft og kvalifikationer og til en begrænsning af arbejdernes dispositionsområde, idet ledelsens kontrolmekanismer forbedres. Mens

12. Ved flertallet af de undersøgte teknologier er besparelsen af arbejdskraft vurderet som betydelig eller meget betydelig, og kun i 2 ud af 20 som ubetydelig. Sammenfattende kan man fastslå, at de opnåede resultater for menneskene i de forudgående år også ser ud til at have gyldighed i de kommende årtier: det er »rationaliserende innovationer«, som dominerer. (Kalmbach 1978, s. 397) Citatet stammer fra en undersøgelse fra ISO-instituttet. Case-studier af indførelse af NC og CNC teknologier i maskinbygningssektoren konstaterer tilsvarende virkninger med hensyn til rationalisering. 
en lille gruppe faglærte under omstændighederne kan rekvalificere sig eller endog erhverve højere kvalifikationer, vil det altovervejende flertal være underlagt en tendentiel trussel mod arbejdspladser og kvalifikationer. Det er altså ikke stabilisering, men фdelaggelse eller polarisering af moderniseringspolitikkens sociale basis, der - formidlet over virksomhedernes restruktureringsproces - er samme politiks resultat!

\section{Kommunikationsteknologi på reproduktionsområdet.}

Et nyt ekspanderende marked med stor betydning i fremtiden ventes at opstå i forbindelse med anvendelsen af nye kommunikationsteknologier. Disse teknologier og deres kapitalistiske udvikling og anvendelse truer ikke blot - som ovenfor antydet - kvalifikationer og arbejdspladser i den offentlige og private administration. De åbner også muligheder for dé store kapitaler, som allerede behersker dagbladsmarkedet, til privat udnyttelse af en underholdningssektor, der kan udvides enormt med kabelteknologien. Med kabelradio og -fjernsyn opstår ikke alene nye investeringsmuligheder for brakliggende pengekapital, men samtidig muligheden for en privat kapitalvalorisering af medierne og dermed indflydelse på og indoktrinering af vide kredse i befolkningen.

Virkningen af denne modernisering burde, kan man allerede nu skønne, i det mindste være i diamentral modsætning til det grundlæggende socialdemokratiske menneskebillede, til den »myndige borger «, og til de mål, som den socialdemokratiske uddannelsesreform og mediepolitik tidligere har formuleret. Inden for den givne økonomiske strukturs rammer turde disse virkninger imidlertid næppe kunne forhindres eller kontrolleres (f.eks. giver især satelit-TV den private kapital allehånde undvigelsesmuligheder på hånden).

\section{Energiproduktion som forudsætning for modernisering.}

Den fremherskende investeringstype er »rationaliserende innovation «, og den skal gøre virksomhederne stadigt mindre afhængige af arbejdskraft. Samtidig bliver produktionsprocessen relativt, men også absolut, afhængig af billige energileverencer. At gøre energiproduktionen mest mulig uafhængig af exogene faktorer, at på langt sigt opnå et i forhold til verdensmarkedet gunstigt prisniveau og at bevare en førerposition på verdensmarkedet hvad angår levering af produktionsteknologi til energisektoren, disse er intentionerne, som står bag den forcerede statslige støtte til

13. Netop for det arbejdspolitisk relevante spørgsmål om gennemsætteise af herredømme via teknologisk formidlet kontrol inden for virksomheden, må disse former for innovationer og fremme gennem moderniseringspolitikken være af betydning. 
energiteknologien og særligt til kerneenergien. (Faktisk er kerneenergien den hidtidige moderniseringspolitiks paradeeksempel og har også slugt hovedparten af forsknings- og energiministeriets midler).

Denne forcerede udbygning af energiproduktionen har samfundspolitiske og økologiske følgevirkninger, som i sidste ende truer endog befolkningens fysiske overlevelse. Samfundspolitisk drager energiproduktionens planlægnings- og realiseringsmåder ikke blot en koncentration af den erhvervsaktive befolkning i kompakte byområder efter sig; de også af staten anerkendte farer ved anvendelsen af f.eks. kernekraftteknologien fører til statslige præventivforanstaltninger, som ikke mindst pga. de nye energiteknologiers farlighed i deres logik peger frem mod statens totale kontrol med samfundet - en stat som Robert Jungk beskriver som »atomstaten«.

Særligt kerneenergipolitikkens placering som et væsentligt element i moderniseringspolitikken har ført til samfundsmæssig modstand; denne modstand har ikke blot begrænset sig snævert til kerneenergien, men har - da politikere og kapital vedholdende postulerer, at kerneenergien er en uomgængelig forudsætning for fortsat $\varnothing$ konomisk vækst - videre stillet spørgsmål ved den vækstrelaterede konsensus overhovedet, $o g$ har, for så vidt disse »nye sociale bevægelser« organiserer sig i alternative partier, også sået tvivl om de politiske processers spilleregler.

\section{Ambivalenser i moderniseringspolitikken (II): Implementationsproblemer, deres håndtering i forhandlingssystemer og legitimeringens problem.}

I sidste afsnit har vi allerede beskrevet sådanne virkninger af moderniseringspolitikken, som modsiger dens målsætning om at underbygge den samfundsmæssige konsensus og især at fastholde arbejderklassens kerne i denne konsensus. På virksomhedsniveau følges restruktureringen af jobindskrænkninger og/eller dekvalificering (samtidig med en mulig re- og opkvalificering for en lille gruppes vedkommende). På reproduktionsområdet undermineres reformmålsætninger og i stedet indledes en (mulig) kontrol over og indflydelse på borgerne gennem privatkapitalistisk drevede medier. Med kerneenergien som eksempel på en central moderniseringsteknologi berørte vi den $\varnothing$ kologiske trussel og den heri begrundede samfundsmæssige modstand (på tværs af de traditionelle samfundsmæssige skillelinier!).

Inden for moderniseringsdiskussionen er det imidlertid også erkendt, at de kortfristede sociale følger, som gør sig gældende på enkeltvirksomheds- og 
brancheniveau, kan være i modstrid med den del af målsætningen, som angår legitimeringen. Såfremt disse følger ikke skal bearbejdes eksternt (således som f.eks. i Scharpf's forslag om et opbløde den fremvoksende friktionelle arbejdsløshed med statslige jobskabelsesprogrammer (Scharpf 1976)), er disse delegitimerende virkninger af moderniseringspolitikkens implementeringsfase tænkt at skulle opfanges i forhandlingssystemer. Videre er disse forhandlingssystemer et væsentligt medium for moderniseringspolitikken overhovedet. De tjener ikke kun til at håndtere mulige legitimeringsproblemer; de tjener også som medium for problemregistrering, for tilvejebringelse af information og for gennemsættelsen (implementeringen) af moderniseringspolitikken.

Det er derfor nødvendigt at diskutere den betydning, som moderniseringspolitikken har for begrebet »den udvidede stat«, sådan som vi berørte det i indledningen. Hidtil er denne »udvidelse« kun blevet forstået sådan, at med moderniseringspolitikken forlader politikken det nationaløkonomiske niveau for i stedet at underst $\varnothing$ tte restruktureringen af de stoflige produktionsmidler på branche- og virksomhedsniveau. Begrebet »den udvidede stat « omfatter - i relation til arbejdspolitikkens arena - imidlertid ikke kun et udvidet emneområde for den statslige ageren, men også en kompletering af medierne 'ret' og 'penge' med det nye medium 'forhandlingssystem'.

Vi har defineret dette forhandlingssystems funktion i retning af, at det er herigennem, at moderniseringspolitikken skal planlægges og gennemsættes (implementeres). Det forekommer mig, at ét forslag, som især Hauff/Scharpf (1975) har stået for, er prototypen på forhandlingssystemets funktion i moderniseringspolitikkens sammenhæng; forslaget har samtidig strukturelle ligheder med de praktiserede »Krisenbewåltigungskartellen « (sml. Esser m.fl. 1978 over eksemplet Saarkrisen). Hauff/Scharpf (1975) nyttiggjorde i deres forslag den forhåndenværende korporatistiske struktur (især på brancheniveau) og ville gennemsætte og legitimatorisk underbygge moderniseringspolitikken som en »aktiv strukturændringspolitik « gennem en »Konzentrierten Aktion ${ }^{14}{ }^{14}$

14. Når den »Konzentrierte Aktion «'s funktion i Hauff/Scharpf's begreb om modernisering analyseres kort i det følgende, så hævdes det ikke af den grund, at der ikke i korporatistiske strukturer kan udvikles positioner hos fagforeningerne mod branchekapitalen. Blot må sådanne modpositioner, der hvad enten man vil det eller ej også må stille spørgsmål ved produktivitetsudviklingens retning, være dysfunktionelle i forhold til dette begreb (om modernisering). Det forhold, at arbejdsgiverne med den vedvarende krise viser en mærkbar tilbageholdenhed hvad angår nye korporatistiske sammenslutninger, synes at tale for den tese, at under krisen vil fagforeningerne i sådanne sammenslutninger søge at fastfryse tidligere forsvarslinier overfor arbejdsgiverne mens arbejdsgiverne mister deres strukturelle fordel på arbejdsmarkedet. Denne sammenhæng er især forsømt i den tyske korporatisme-diskussion. 
Grundlaget for denne plan må forstås ud fra den ovenfor anførte tese om krisen som politikkens chance; vel at mærke ikke kun i den betydning, at restruktureringsprocessen skal fremskyndes med politikkens hjælp, men også (og først og fremmest!) i den betydning, at det først er i krisen, at de berørte $\varnothing$ konomiske subjekter åbner sig for indsigten i hin nødvendige og nødvendigvis smertefulde restruktureringsproces. Konkret: Chancen for politiske interventioner, der ellers ville blive oplevet som uantagelige indgreb $\mathrm{i}$ ledelsens eller overenskomstparternes autonomi, opstår fordi den krisefyldte tilspidsning på arbejdsmarkedet indebærer en arbejdsløshedstrussel, som diciplinerer arbejderne (og fordi markedsforholdene tvinger arbejdsgiverne til nytænkning). For Scharpf (1974) og Hauff/Scharpf (1975) skal disse interventioner derfor samfundspolitisk underbygges med Konzentrierten Aktioner på brancheniveau, hvor repræsentanter for videnskaben, overenskomstparterne og staten i fællesskab forhandler og gennemsætter »det økonomisk nødvendige «. Mens arbejdsgiverne til denne »Konzentrierte Aktion« skal medbringe deres faglige viden, deres markedskendskab og deres planlægningsevner, så tilkommer der især fagforeningerne en oplysnings- og formidlingsfunktion. (sml. Scharpf 1974, s. 24).

En sådan oplysnings- og formidlingskompetence er også påkrævet. Faktisk drejer det sig ikke kun om at formidle til arbejderne i de brancher, der ikke mere skal opretholdes gennem subventioner, at deres arbejdspladser er (verdensmarkeds-) konkurrencens nødvendige offer; men det drejer sig også om at gennemsætte de nødvendige restruktureringer indenfor vækstbrancherne imod forhold, som arbejderne har vundet hævd på (arbejdspladser, kvalifikationer, lønniveau). Fagforeningerne henvises altså her til rollen som formidlere at nødvendige restruktureringsprocesser, der for medlemmerne er forbundet med anseelige materielle forandringer og i realiteten tab.

Ud fra dette eksempel kan nævnte forhandlingssystems funktion (som den statslige reguleringskapasitets tredie 'medium') udarbejdes. Statens systemgranse forbliver - som under den Konzertierten Aktion - uberørt. Arbejdsgivernes markedskendskab og faglige viden skal tvært imod direkte $\emptyset$ ge den statslige reguleringskapacitet i forhold til den kapitalistiske restrukturering, idet der med deres inddragelse sker en udvidelse af informationsgrundlaget for prognoser over den økonomiske udvikling, som ellers vanskeligt kunne opnås $i$ en privat-decentral produktionsmåde. I modsætning hertil tilsigtes en forskydning af statens aktivitetsgraenser sådan, at de legitimeringsproblemer, der er forbundet med at argumentere for indskrænkninger (og dermed reduktionen af arbejdspladser og kvalifikationer), lægges ind i de faglige 
organisationer. Som »politisk gennemstrømningsovn« for restruktureringskrisens $\varnothing$ konomiske og samfundsmæssige funktioner, har moderniseringspolitikken ambivalente funktioner, med grundlag i reproduktionsprocessens modsigelsesfyldte struktur. Disse ambivalente funktioner giver legitimeringsproblemer af relevans for aktivitetsgrænserne; legitimeringsproblemer, der så skal lægges ud i forhandlingssystemer.

Hvorvidt det nu er muligt at udvide statens aktivitetsgrænse ved at stuve legitimeringsproblemerne af vejen i fagorganisationerne, afhænger ikke mindst af organisationerne selv. På den ene side er den faglige organisering i Forbundsrepublikken struktureret efter brancher og ligger derfor helt åben for en sådan politik. Ud fra den traditionelle korporatistiske struktur og forestillingen om en fælles produktionsinteresse for lønarbejde og kapital (sml. her Hugo Sinzheimers tidlige sammenfatning af denne teori i fagbevægelsen ${ }^{15}$ ) er et sådant samarbejde $\mathrm{i}$ »Konzentrierten Aktioner« nærliggende. En række eksempler tyder faktisk på, at en udvidelse af de statslige aktivitetsgrænser i form af en Konzentrierte Aktion ikke er urealistisk. Det gælder således forestillingen om, at den økonomiske krise først og fremmest skyldes arbejdsgiveres »mismanagement « (mens fagforeningerne opfører sig som kvasiideelle branchekapitalister, sml. Esser 1982). Det gælder videre fagforeningernes oprettelse af innovationsrådgivningssteder ${ }^{16}$, samt samarbejdet i krisekarteller (sml. stålkrisen i Saar, Esser m.fl. 1978).

Imidlertid stiller problemet sig ikke kun på den måde, at de falglige organisationer internt må forarbejde legitimeringsproblemerne ved deres politik i forhold til de ramte medlemmer. Oveni kommer den opspaltning af fagforeningsbevægelsen i vindere og tabere, som er anlagt i og med de brancheorganiserede »Konzentrierten Aktioner « (jvf. Hoffmann 1981), og frem for alt er spørgsmålet, om kapitalens repræsentanter overhovedet (og især inden for vækstindustrierne) på langt sigt vil møde op i disse korporatistiske strukturer, da arbejdsmarkedet jo netop er gunstigt for arbejdsgiverne! Betingelserne for en udvidelse af aktivitetsgrænserne gennem det nye medium 'forhandlingssystemer' hænger således ikke kun sammen med de samfundsmæssige strukturer (et standpunkt, som f.eks. korporatismediskussionen har absoluteret). De afhænger lige så meget af kapitalreproduktionen. Om

15. Jvf. her især Wolfgang Müllers arbejde (1973).

16. I indretningen af innovationsrådgivningssteder bliver det endnu engang tydeligt, at enkeltkapitalen (især den fra middelklassen) er underlagt en nødvendig bonert problemerkendelses- og planlægningsevne, og at fagforeningerne her i realiteten - med Essers ord (1982) - handler som quasi ideel branche-totalkapitalist. 
kapitalsiden indfinder sig i de korporatistiske strukturer, som man forestiller sig, afhænger ikke mindst af, om den regner med, at »forholdenes stumme tvang « er et meget mere virksomt middel til at gennemsætte det økonomisk nødvendige end korporatistiske forhandlingssystemer, der netop i krisetider rummer den fare for kapitalen, at arbejderne og fagforeningerne anvender dem som forsvarsbastioner.

\section{Endnu engang:}

Er en udvidelse af staten det samme som

en udvidelse af statens muligheder?

- Enkelte konklusioner på undersøgelsen

af moderniseringspolitikken

som element på den arbejdspolitiske arena.

Vores indledende problemstilling havde udgangspunkt i tesen om en $» u d-$ videt stat«. Denne tese er især blevet sat i relation til moderniseringsdiskussionen. På grundlag af vore resultater her, kan vi kun formulere enkelte foreløbige svar på de rejste spørgsmål:

Ad. (1): Den privat-decentrale reproduktionsstrukturs systemgrænse, som garanteres af den private ejendomsret (til produktionsmidler), bliver ikke berørt af moderniseringspolitikken; heller ikke når markedsradikale teoretikere inden for forsknings- og teknologipolitikkens område i denne politik allerede ser et videregående skridt i retning af planstatslig styring. Faktisk bliver netop denne reproduktionsstruktur - endog på verdensmarkedsbasis - taget som givet udgangspunkt for de politiske målsætninger, mens det tillægges enkeltkapitalerne, at de på grund af deres begrænsede planlægningsog tidsressourcer næppe vil være i stand til at optage i deres investeringsplanlægning, hvad verdensmarkedet kræver på mellemlangt sigt!

Ad. (2): Også moderniseringspolitikken knytter an til kapitalreproduktionens funktionelle former; men til den produktive kapitals kredsl $\varnothing \mathrm{b}$ og ikke til varekapitalens kredsløb, sådan som den keynesianske niveauregulering g $\varnothing \mathrm{r}$ det. Her igennem er anknytningen til kapitalkredsløbets stoflige forudsætninger givet, uden at kapitalkredsløbet selv ophæves. Moderniseringspolitikken knytter an til det punkt i kapitalreproduktionen, hvor reproduktionens periodisk selvstændiggjorte former påny tvinges sammen af kriseforløbet. Den kan derfor kun styrke reproduktionsprocessen kapitalimmanent (særligt i et strukturbruds historiske fase) ved at 
fremhjælpe effektiviseringen af (den produktive kapitals) stoflige strukturer, men uden at kunne dreje disse i andre retninger, som måtte være politisk ønskværdige under de omstændigheder. Historisk er der på dette grundlag for moderniseringspolitikken kun tilbage at håbe på, at Forbundsrepublikken igen kan opnå en stigende beskæftigelse via en $\emptyset$ get akkumulation på basis af en offensiv på verdensmarkedet. Stagnerer verdensmarkedet vil en sådan offensiv imidlertid finde sted på bekostning af andre nationale kapitalers akkumulation og i sidste ende også på bekostning af deres betalingsevne - hvormed det igen vil blive umuligt at externalisere beskæftigelsesproblemet.

Ad. (3): En af de nye kvaliteter ved mediet 'forhandlingssystem' består $\mathrm{i}$, at statens indgriben (hhv. statens organisering af forhandlingssystemet) instrumentaliserer kompromislinien mellem lønarbejde og kapital, altså selve »aktivitetsgræensen «, som medium for statslig intervention. 'Forhandlingssystemer' er ikke kun typisk for politiktypen moderniseringspolitik (en af helhedsstyringens hjertesager var den Konzertierte Aktion). Disse forhandlingssystemer vinder imidlertid i betydning både som middel til at udvide informations- og planlægningskapasiteten og i deres formidlingsfunktion, når interventionsniveauet forskydes til branche- og virksomhedsniveau. Samtidig bliver de imidlertid også bundet meget snævrere (end den relativt uforbindtlige Konzertierte Aktion på makroniveau) til, at de umiddelbare interesseparters repræsentation skal give beviselige resultater. Sådanne resultater lader sig vanskeligt opnå for tiden (dvs. i stagnationsfasen) med enkelt- og branchekapitaler begunstiget af krisens virkning på arbejdsmarkedet på den ene side og arbejdere udsat for restruktureringsprocessernes negative virkninger på den anden.

Moderniseringspolitikkens ambivalente funktioner er bestemt gennem dens relationer til den produktive kapitals kredsløb. Relationer, som er determineret gennem reproduktionsprocessens nødvendigvis modsigelsesfyldte strukturer: Understøttelsen af arbejdets produktivkraftudvikling indebærer under en privat-decentral (kapitalistisk) produktionsmåde overflødiggørelse af arbejdskraft, dekvalificering og tryk på lønniveauet. I et historisk perspektiv bliver moderniseringspolitikkens sociale basis dermed snarere фdelagt end underbygget. Bag disse strukturelle og historiske grænser for en »udvidet stat « ligger endvidere fortsat de såkaldte systemgranser, som uden tvivl vil stække vingerne på den moderniseringspolitisk udvidede stat. 


\section{Litteraturliste}

Altvater, E., Hoffmann, J., Semmler, W., 1979: Vom Wirtschaftswunder zur Wirtschafts krise Ökonomie und Politik in der Bundesrepublik, Berlin

Altvater, E., Kallscheuer, O. (Hrsg.), 1979: Den Staat diskutieren, Berlin

Altvater, E., 1982: Vom Abbau zum Umbau des Sozialstaats, i Prokla 49

Baethge, M., 1982: Die Kopfarbeit macht der Computer, i: Frankfurter Rundschau v. 12. 11. 1982

Blanke, B., Jürgens, U., Kastendiek, H., 1975: Das Verhältnis von Politik und Ökonomie als Ansatzpunkt einer materialistischen Analyse des bürgerlichen Staates. I: Dies., Kritik der Politischen Wissenschaft, Frankfurt/Main

Blanke, B., 1976: Entscheidungsanarchie und Staatsfunktionen: Zur Analyse der Legitimationsprozesse im politischen System des Spätkapitalismus, I: Ebbighausen. R. (Hrsg.): Bürgerlicher Staat und politische Legitimation, Frankfurt/Main

Blanke, B., 1977: Formen und Formwandel des politischen Systems in der bürgerlichen Gesellschaft. I: Brandes, V. u.a. (Hrsg.): Handbuch Staat, Frankfurt am Main-Köln

Bolle, M., 1977: Globalsteuerung und ökonomische Krise, i: Brandes u.a. a.a.O.

Buci-Glucksmann, Ch., 1982: Sozialdemokratie und keynesianischer Staat, i: Prokla 47

Dörr, G., Naschold, F., 1982: Arbeitspolitische Entwicklungen in der Industriearbeit - Zum Zusammenhang von Belastung, Qualifikation und Kontrolle, in: Schmidt, G., Braczyk, H.-J., Knesebeck, J. von dem (Hrsg.): Materialien zur Industriesoziologie, i: KZfSS-SH 24/1982

Esser, J., Fach, W., Väth, W., 1978: Strukturelle Arbeitslosigkeit und politisches Konflikt potential Die Krise der saarländischen Stahlindustrie, i: Prokla Nr. 31

Esser, J., Fach, W., Simonis, G., 1980: Grenzprobleme des »Modells Deutschland«, i: Prokla 40 Esser, J., 1982: Gewerkschaften in der Krise, Frankfurt/Main

Hauff, V., Scharpf, F.W., 1975: Modernisierung der Volkswirtschaft, Köln

Hoffmann, J., 1977: Staatliche Wirtschaftspolitik als Anpassungsbewegung der Politik an die kapitalistische Ökonomie, i: Brandes u.a., a.a.O.

Hoffmann, J., 1978: Ökonomischer oder politischer Konjunkturzyklus? Diss. FU Berlin

Hoffmann, J., 1982: »Das Ende der Fahnenstange« - Sozialdemokratie und keynesianischer Klassenkompromiss in der Bundesrepublik, i: Prokla 49

Jürgens, U. / Naschold, F., 1982: Arbeitspolitik - Entwicklungstendenzen und Politikformen, i: Joachim Jens Hesse (Hrsg.): Politikwissenschaft und Verwaltungswissenschaft. PVS-Sonderheft 13/1982, S. 327-343

Kalecki, M., 1943: Political Aspects of Full Employment. Abgedruckt i: Hunt, E.K., Schwarzt, J.G. (eds.) 1972: A Critique of Political Economy, Harmondsworth

Kalmbach, P., 1978: Beschäftigungssicherung durch »Modernisierung der Volkswirtschaft «? I: Markmann, H., Simmert, D., (Hrsg.): Krise der Wirtschaftspolitik, Köln

Kern, H., Schumann, M., 1982: Gefragt ist der mündige Arbeiter, i: Frankfurter Rundschau v. 28.10. 1982

Kitschelt, H., 1980: Kerneenergiepolitik - Arena eines gesellschaftlichen Konflikts, Frankfurt/ Main

(Litteraturlisten fortsættes på side 100) 


\title{
Om forholdet mellem politik og økonomi på det kapitalistiske verdensmarked.
}

\author{
Klaus Busch
}

Enhver verdensmarkedsteori må lige fra starten forholde sig til et metodologisk problem, nemlig spørgsmålet om forholdet mellem politik og $\varnothing$ konomi i kapitalens internationale konkurrence. I den kapitalistiske produktionsmådes struktur er politik og økonomi specifikt adskilte instanser, hvor økonomien har den dominerende rolle. Derfor kan og må en unders $\varnothing$ gelse af kapitalens almene akkumulations lov abstrahere fra den politiske instans. Dette metodiske princip må imidlertid ikke overføres til verdensmarkedsanalysen. Den politiske instans indgår nemlig, selv i de mest liberalt prægede perioder som et moment i den internationale konkurrence, nemlig i form af nationalstaten. At udelukke den politiske instans ville således være det samme som at tage udgangspunkt i en falsk præmis. Det første problem, teorien må forholde sig til, er forskellen mellem den kapitalistiske produktionsmådes almene struktur og dens historiske fremtrædelsesform på verdensmarkedet, hvor fremtrædelsesformen modsvarer den almene strukturs logik. Det første spørgsmål lyder: Hvorledes er nationalstatsstrukturen opstået i det internationale system, og hvorfor har borgerskabet ikke været i stand til også på verdensmarkedet at gennemsætte en struktur i forholdet mellem politik og økonomi, som kan siges at være i overensstemmelse med den kapitalistiske produktionsmådes logik?

I det foreliggende arbejde skal vi udvikle den tese, at den forskel mellem den kapitalistiske produktionsmådes logik og historie, som viser sig i nationalstatsstrukturen, kun kan forklares, hvis man tager udgangspunkt i de særlige betingelser ved overgangen mellem feudalisme og kapitalisme. I sidste instans skyldes cementeringen af de nationale statsstrukturer, som allerede var skabt af absolutismen, de europæiske staters usamtidige og uensartede udvikling. På grund af deres forskellige nationale særpræg lykkedes det kun de borgerlige revolutioner at forvandle de førkapitalistiske relationer mellem politik og økonomi i samfundets indre, hvorimod de eksternt bevarede den allerede eksisterende sammensmeltning af instanserne politik og økonomi. 
Denne historiske analyse løser imidlertid ikke alle verdensmarkedsteoriens problemer. Man kunne forestille sig, at nationalstatens eksistens, som en udenfor $\varnothing$ konomien liggende tvangsmagt i den internationale konkurrence, ville gøre det omsonst at lede efter økonomiske lovmæssigheder for kapitalernes verdensmarkedsforhold, da disse vil indeholde såvel økonomiske som politiske momenter. Denne tese er faktisk ret udbredt i den foreliggende litteratur. Vi kan imidlertid ikke tilslutte os denne opfattelse; og vi vil her forsøge at begrunde den tese, at nationalstaten i verdenskapitalens opgangsfaser vil begrænse sine indgreb i den internationale konkurrence til et minimum, således at der fremstår specifikke økonomiske lovmæssigheder, som kun har gyldighed for kapitalens verdensmarkedsbevægelse.

Vore afsluttende undersøgelser er forbeholdt spørgsmålet om nationalstatens resistens endnu to til tre århundreder efter de første borgerlige revolutioner. Vi vil fremlægge de grunde, som efter vor opfattelse, kan forklare, hvorfor nationalstatssystemet trods den voksende internationalisering har kunnet opvise en så forbløffende stabilitet.

Efter således at have udfoldet vore teser om de tre problemkomplekser nationalstatens genese, verdensmarkedets lovmæssigheder og nationalstatens reproduktionstendens - vil vi tage andre standpunkter i den hidtidige verdensmarkedsdiskussion op til kritisk behandling. Hvad angår forholdet mellem politik og $\varnothing$ konomi på verdensmarkedet, er der i de hidtidige undersøgelser blevet udviklet stærkt divergerende positioner, som vi kort vil skitsere og kritisk vurdere i forhold til vore egne teser.

\section{Om forholdet mellem politik og фkonomi $i$ den feudale produktionsmåde.}

Selv om den borgerlige revolutions program knytter an til feudalismens absolutistiske form, er vi nødt til at begynde vor historiske skitse med en analyse af den middelalderlige feudalisme. I middelalderen udvikledes den særlige feudalistiske struktur i forholdet mellem økonomi og politik, som også gjaldt under absolutismen, selv om denne regeringsform ganske vist medførte betydelige ændringer i de herskende statsstrukturer.

\section{Den middelalderlige feudalisme.}

Jordbesiddelsens struktur.

Det er et karakteristisk træk ved den feudale produktionsmåde ${ }^{1}$, som opstod i det 9. århundrede som en syntese af den antikke og den germanske

1. Analysen af den middelalderlige feudalisme bygger primært på følgende værker: L. Kuchenbuch/B. Michael (red.): Feudalismus - Materialien zur Theorie und Geschichte, Frank 
produktionsmåde, at den gejstlige og verdslige adel tilegner sig landbrugets merprodukt gennem anvendelse af ikke- $\varnothing$ konomisk magt. Bonden, som ikke er adskilt fra produktionsmidlerne og derfor principielt kan reproducere sig autonomt - hvilket er den væsentligste forskel i forhold til slaveri og lønarbejde - bliver med politiske midler tvunget til at afhænde sit merarbejde eller produktet af sit merarbejde. Den politiske og ideologiske begrundelse for denne $\varnothing$ konomiske udbytning er bondens subsumtion under lensordningen, som på alle niveauer, fra kronen til bønderne, fastlægger et system af rettigheder og pligter mellem lensherre og lensmand. Livegenskab og/eller stavnsbinding er udtryk for bøndernes politiske/ økonomiske binding til jordbesiddelsen. Tilegnelsen af landbrugets merprodukt sker på den ene side $\mathrm{i}$ form af den direkte rente, som fra begyndelsen optræder i en broget blanding af arbejds-, produkt- og/eller pengerente, og på den anden side $\mathrm{i}$ form af afgifter, som adelen kan presse ud af landsbyfællesskaberne gennem anvendelse af sin jurisdiktionelle magt og øvrighedsret (indirekte rente). Den sidstnævnte form for feudal udbytning, som kan optræde i mangfoldige former som retsgebyrer, mølle-, bageovns-, kældergebyrer m.v. er ofte en større belastning for bønderne end de direkte renteafgifter.

Uanset om man som Althusser/Balibar ${ }^{2}$ hævder, at den politiske instans i den feudale produktionsmåde er dominerende i forhold til økonomien, eller som Anderson ${ }^{3}$ betragter de to instanser som sammensmeltede, er det et karakteristisk træk ved denne produktionsmåde, at der sker en tilegnelse af merproduktet med ikke- $\varnothing$ konomiske tvangsmidler. Udbytningen af de umiddelbare producenter formidles ikke økonomisk, men forudsætter, at der anvendes politiske magtmidler. Det skal desuden understreges, at forholdet mellem politik og økonomi strukturelt set er ens i systemets indre og ydre reproduktion. Etableringen af det politiske herredømme fremstår som en betingelse for den feudale produktionsmådes udbredelse til områder, som tidligere har været domineret af frie bønder eller måske

furt-Berlin-Wien 1977; H. Pirenne: Sozial- und Wirtschaftsgeschichte Europas im Mittelalter, München 1982; P. Andersen: Von der Antike zum Feudalismus - Spuren der Übergangsgesellschaften, Frankfurt/M. 1978; M. Dobb: Entwicklung des Kapitalismus - Vom Spätfeudalismus bis zur Gegenwart, Köln-Berlin 1972; C.M. Cipolla/K. Borchardt (red.): Mittelalter, Bd. 1 i serien Europäische Wirtschaftsgeschichte, StuttgartNew York 1978; G. Duby: Krieger und Bauern - Die Entwicklung von Wirtschaft und Gesellschaft im Frühen Mittelalter, Frankfurt/M. 1981; R. Brenner: Das Weltsystem - Theoretische und historische Perspektiven, i J. Blaschke (red.): Perspektiven des Weltsystems - Materialien zu Immanuel Wallerstein, 'Das Moderne Weltsystem', Frankfurt/M. 1983.

2. L. Althusser/E. Balibar: Das Kapital lesen, Bd. II, Reinbek bei Hamburg 1972, s. $268 \mathrm{ff}$.

3. Anderson, op.cit., s. $175 \mathrm{ff}$. 
endog har været helt uden herremænd, dvs. en betingelse for etablering af et udbytningsforhold til frie bønder eller bønder, som for nylig har koloniseret et område. Hvis man ønsker at udvide udbytningsområdet ind $\mathrm{i}$ allerede feudaliserede territorier er det tilsvarende en betingelse, at man benytter sig af ikke- $\varnothing$ konomiske tvangsmidler, i reglen militære aktioner.

Både den indre reproduktion og den ydre udvidelse af den feudale produktionsmåde er altså baseret på én og samme strukturelle instansrelation.

\section{Byøkonomien.}

Man kan nu spørge sig, hvilken relation består der mellem håndværket $\mathrm{og}$ kapitalens antediluvianske former, handel og åger, på den ene side og den feudale produktionsmådes struktur på den anden. Går byøkonomien på tværs af den landlige feudale produktionsmåde, udgør den feudalismens antitese, eller udspringer de begge af én og samme struktur? Forfattere som Pirenne og Sweezy ${ }^{4}$ betragter handel og bytteøkonomi som feudalismens modsætning. De betragter byøkonomiens og handelens udvikling som den feudale produktionsmådes opløsningsferment, som forbereder overgangen til kapitalismen. Denne position, som er rigt repræsenteret i litteraturen ${ }^{5}$, begår den fejl, at sætte feudalisme lig med naturaløkonomi og kapitalisme lig med bytteøkonomi. Den udvisker desuden den specifikke forskel mellem kapitalens oprindelige former, handel og åger, og den industrielle kapitalisme. Det skal yderligere understreges, at byøkonomien, håndværkslavene og købmandskapitalens gilder, bygger på den samme relation mellem instanserne som den landlige feudalisme. Det politiske herredømme, dvs. magten til monopolistisk at kontrollere byernes markeder og produktion ved hjælp af oplagringsret, toldret, erhvervsregulering og pris- og mængderegulering, udgør grundlaget for denne by $\varnothing$ konomi. Dette herred $\varnothing \mathrm{mme}$ over $\varnothing$ konomien, som er baseret på politisk magt, har form af lav, gilder og korporationer. Hvis det under feudalismen lykkes for byen overfor de relevante landsherrer at gennemtvinge afgiftfrihed, en selvstændig retsorden og en selvstændig $\emptyset$ vrighedsret er den »fri«. I forhold til det omgivende land og de andre byer udgør byen imidlertid et monopolforbund, som indenfor sit eget territorium hersker over handel og næringsliv. Merrington, som med udgangspunkt i Dobb har udviklet en af de mest relevante analyser af byen under feudalismen, formulerer denne sammenhæng på følgende måde: »Den »kapital«

4. Pirenne, op.cit., s. 184ff. samt Sweezy, op.cit., s. $41 \mathrm{ff}$.

5. F.eks. E. Krippendorff: Internationalse System als Geschichte - Einführung in die internationalen Beziehungen 1, Frankfurt/M. 1975. 
og de »markeder «, som var grundlag for byernes vækst under feudalismen, kan på ingen måde betragtes som direkte forgængere for det kapitalistiske verdensmarked. Det ville være fejlagtigt ensidigt at forstå de middelalderlige byers »frihed « som værende udenfor den feudale sammenhæng; den feudale sammenhæng var nemlig bestemmende for »den ydre form « af købmandskapitalens frihed ligesom den definerede dens grænser. På trods af sin autonomi var byen langt fra en »ikke- -feudal $\varnothing$ «(Postan); i sin frihed og udvikling som en organiseret eller forenet enklave følger den heller ikke »sine egne tilbøjeligheder «, som det historisk formuleres af Weber. Dens oprindelse og grænser må i stedet søges i suverænitetens omfattende parcellering, som igen skyldes et sammentræf af bestemte politiske og økonomiske underordnings-/tilegnelsesforhold i den feudale produktionsmåde. Den fortsatte eksistens af dette byfællesskabs autonomi som et »kollektivt herredømme « indenfor en totalsamfundsmæssig celle-struktur, som bygger på »niveaudelte « suveræniteter, krævede netop den mest vidtgående udvikling af købmandskapitalen i den middelalderlige by « ${ }^{6}$.

Under feudalismen beror den økonomiske udvikling af handel og næringsliv primært på politisk herredømme; i byøkonomien er instanserne $\emptyset$ konomi og politik ligeså sammensmeltede som i den landlige økonomi, hvilket kan betragtes som den væsentlige forskel i forhold til den kapitalistiske produktionsmåde. Med industrikapitalens herredømme adskilles områderne politik og økonomi, samtidig med at det politiske område underordnes det økonomiske. I den kapitalistiske produktionsmåde foregår kapitalakkumulationen og kapitalernes konkurrence på grundlag af værdiloven, mens handelskapitalens akkumulation og byhåndværkets udvikling under feudalismen afhænger af de hertil knyttede korporationers politiske magt, af deres evne til gennem brug af det politiske herredømme at sikre sig priviligerede og monopolistiske markeds- og produktionsstrukturer ${ }^{7}$.

\section{Den parcellerede suvercenitet.}

Af fremstillingen af den specifikke sammenfletning af politik og $\varnothing$ konomi i byen og på landet er det allerede implicit fremgået, at den middelalderlige feudalisme er et system af parcelleret suverænitet. Ganske vist er monarken som overhoved placeret i toppen af lenspyramiden; imidlertid må han $\emptyset$ konomisk reproducere sig på grundlag af sine egne besiddelser, idet hans skatteindtægter er minimale. Han råder hverken over noget administrativt

6. J. Merrington, Stadt und Land in Übergang zum Kapitalismus, i Sweezy m.fl., op.cit., s. 239.

7. Jvf. P. Vilar: Der Übergang vom Feudalismus zum Kapitalismus, i Kuchenbuch/Michael, op.cit., s. 678ff. samt L. Kuchenbuch/B. Michael: Zur Struktur und Dynamik der 'feudalen' Produktionsweise im vorindustriellen Europa, i Kuchenbuch/Michael, op.cit., s. 694ff. 
apparat af betydning eller over en stående hær. Da den lovgivende magt kun har ringe betydning $\mathrm{i}$ et herredømmesystem, som bygger på sædvaneretten, er monarken også uden særlige lovgivningsmæssige kompetencer. Endelig er den afgørende magt i dette system, den retsudøvende, som fortolker og anverder sædvaneretten, decentralt organiseret, selv når der er tale om idømmelse af dødsstraf; den ligger således i hænderne på de lokale jordbesiddere og de autonome byer. De lokale myndigheder råder over samtlige magtmidler til sikring af deres $\varnothing$ konomiske og politiske herredømme. Feudalismen kan imidlertid ikke helt undvære et magtcentrum i toppen: Ydre og indre trusler mod dette herredømmesystem nødvendigg ør et militært forbund, som kan mobiliseres centralt. Den trussel, som normannerne, de $\varnothing$ st-asiatiske rytterfolk og saracenerne udgjorde mod mellem-, øst- og sydeuropa, gjorde det i stigende grad muligt for monarkerne i perioden fra det 9. til det 11. århundrede at indkalde deres vasaller til militærtjeneste. Hvis man skal forhindre et permanent feudalt anarki som følge af de systemimmanente fejder mellem et herredømmeforbunds vasaller og forskellige dynastiers kamp om at udvide deres territorier, er det også nødvendigt med en militær centralinstans. Modsigelsen mellem den lokale feudalmagt og nødvendigheden af en central magt er bestemmende for feudalismens middelalderlige historie. Op mod den nyere tids begyndelse sejrer til sidst de suverænitetsparcellerende interesser, dog med regionale forskelle, som f.eks. mellem det relativt stærkere engelske og franske monarki på den ene side og Det Tysk-Romerske Rige, som er præget af en ekstrem svag krone, på den anden ${ }^{8}$.

\section{Den absolutistiske stat'}

Absolutismens klassebasis.

Feudalismens krise i midten af det 14. århundrede viste sig at resultere i en afgørende forvandling af den overfor beskrevne magtfordeling mellem

8. Anderson, op.cit., s. $180 \mathrm{ff}$.

9. Analysen af den absolutistiske feudalisme bygger primært på følgende værker: P. Anderson: Die Entstehung des absolutistischen Staates, Frankfurt/M. 1979; I. Mieck: Europäische Geschichte der frühen Neuzeit, Stuttgart 1977; C.M. Cipolla/K. Borchardt (red.): 16. und 17. Jahrhundert, Bd. 2 i serien Europäische Wirtschaftsgeschichte, Stuttgart-New York 1979; W. Hubatsch: Das Zeitalter des Absolutismus 1600-1879, Braunschweug 1975; R. Vierhaus: Deutschland im Zeitalter des Absolutismus, Göttingen 1978; P. Brandt/Th. Hoffmann/R. Zilkenat: Preussen - Zur Socialgeschichte eines States - Eine Darstellung in Quellen, Reinbek bei Hamburg, 1981; C. Hill: Von der Reformation zur industriellen Revolution - Sozial- und Wirtschaftsgeschichte Englands 1530-1780, Frankfurt/M. 1977; M. Dobb: Entwicklung des Kapitalismus - Vom Spätfeudalismus bis Zur Gegenwart, Köln-Berlin 1972; W. Treue: Wirtschaft, Gesellschaft und Technik vom 16. bis zum 18. Jahrhundert, Handbuch der deutschen Geschichte, Bd. 12, München 1980. 
krone og adel. Den stærke befolkningstilbagegang som følge af pest og talrige krige (Hundredeårskrigen) som Europa oplevede $\mathrm{i}$ anden halvdel af det 14. århundrede, resulterede i en løsnelse af det feudale udbytningsforhold. Adelen kunne kun hindre den kvantitativt klart reducerede bondestand $\mathrm{i}$ at forlade jorden ved at ophæve eller mildne livegenskabet og reducere rente- og afgiftsbyrden. Denne forskydning i styrkeforholdet mellem denne epokes to hovedklasser blev underst $\varnothing$ ttet af talrige bondeopstande i England, Frankrig og Tyskland. I det østlige Europa skete der en feudal reaktion, idet adelen fik held til at indføre det såkaldte andet livegenskab; i Vesteuropa derimod stod byernes $\varnothing$ konomiske og politiske styrke i vejen for en sådan udvikling, idet de var i stand til at holde en dør åben for de bønder, som evt. skulle ønske at flygte fra den feudale udbytning. Absolutismen, som i denne periode gradvis satte sig igennem i Vesteuropa (Spanien, Frankrig, England), må forstås som en reaktion på den middelalderlige feudale herredømmeordens krise. Kronen fratog stænderne deres politiske magt, men re-stabiliserede på den anden side adelens økonomiske udbytning af bønderne ved hjælp af det fremvoksende centralistiske statsmaskineri (stående hær, skattesystem, bureaukrati). Konflikten mellem monarkiet og feudalmagnaterne, kronens militære neddæmpning af det feudale anarki og den tilpasning, som adelen måtte udvise under absolutismen, må ikke tilsløre, at produktionsforholdene stadig var feudale, og at adelen også under det absolutistiske monarki er den herskende klasse. Herom skriver Anderson: »Absolutismen var i det væsentlige et genudfoldet, fornyet feudalt herredømmesystem, som var bestemt til at tvinge bondemasserne tilbage i deres traditionelle sociale position - på trods af og imod de fordele, de havde vundet gennem den udbredte forvandling af afgifterne. Med andre ord: Den absolutistiske stat optrådte aldrig som neutral opmand mellem airstokratiet og bourgeoisiet og endnu mindre som et værkt $\varnothing j$ for det fremvoksende bourgeoisi rettet mod aristokratiet: Den var det nye politiske rygskjold for en truet adel $\ll^{10}$.

De metoder ved hjælp af hvilke det absolutistiske monarki genoprettede det feudale herredømme, er ganske vist samtidig en mægtig løftestand for den oprindelige kapitalistiske akkumulation. Indførelsen af en stående hær, den systematiske beskatning af de lavere stænder, opbygningen af et administrativt apparat (bureaukrati), indførelse af romerretten og den merkantilistiske økonomiske politik er tilsammen et instrumentarium, hvis primære formål var at sikre og styrke den 
reformerede feudalorden; ethvert af disse momenter begunstigede imidlertid samtidig handels- og manufakturkapitalens udvikling og gødede dermed i feudalismens skød jorden for den kapitalistiske revolution.

\section{Den absolutistiske herredømmesikrings metoder}

1. Den stående har.

Den stående professionelle hær var for de etablerede absolutistiske monarkier det afgørende instrument til afgørelse af territoriale konflikter ${ }^{11}$. Krig, med det formål at erobre territorier, var under den feudale produktionsmåde de mest effektive metode til en hastig forøgelse af rigdommen. Den herskende feudalklasses rigdom var baseret på udbytning af bønderne, således at produktionstilvæksten i den landlige økonomi skete $i$ et meget langsomt tempo. Udvidelsen af de territoriale besiddelser, en udvidet monopolisering af jorden, var derfor en forudsætning for $\emptyset$ get $\varnothing$ konomisk magt. Kampen om afkastet antager derfor i hele feudalismen historie form af krig. De talrige krige i absolutismens epoke, lige fra Karl den femtes og Philip den andens krig, Trediveårskrigen, Ludvig den fjortendes krige, over den spanske arvefølgekrig til syvårskrigen, er således først og fremmest at betragte som feudale stridigheder om afkastet. Samtidig var disse væbnede konflikter imidlertid også af afgørende betydning for handels- og manufakturkapitalens udvikling:

1. Med oprettelsen af lejehære blev produktion af militært udstyr til hær og flåde og handel med disse varer et yderst attraktivt investeringsfelt for handels- og manufakturkapitalen. Næsten overalt i Europa slugte dette område langt hovedparten af statsudgifterne, og fra det 16. til det 18. århundrede var disse hære i næsten permanent aktivitet ${ }^{12}$. Militærmaskineriernes ekspansive potens fremgår af, at Philip den andens hær talte ca. 60.000 mand, mens Ludvig den fjortende havde 300.000 mand i sit sold; hertil kommer, at der i det 16. århundrede endnu var 25 år uden nogen større militær konflikt i Europa, mens der i det 17. århundrede kun var 7 år.

11. Om begyndelsen til de første stående hære i Spanien og Frankrig se Cipolla/Burchardt (red.): 16. und 17. Jahrhundert, op.cit., s. $242 \mathrm{ff}$.

12. Jvf. D. Sella: Die Gewrbliche Produktion in Europa 1500-1700, i Cipolla/Borchardt (red.): 16. und 17. Jahrhundert, op.cit., s. 242ff. samt G. Parker Die Entstehung des modernen Geldund Finanzwesens in Europa 1500-1730, i Cipolla/Borchardt (red.): 16. und 17. Jahrhundert, op.cit., s. $358 \mathrm{ff}$. 
2. Da handelen i absolutismens epoke stadig primært blev drevet som monopolhandel, dvs. beroede på udøvelsen af politisk herredømme, afhang handelskapitalens operationsrum umiddelbart af militær styrke og tilstedeværelse samt af det pågældende monarkis krigslykke. Med udsendelsen af Spaniens, Portugals, Englands, Frankrigs og Hollands kolonihære til Den Nye Verden, til Asien og Afrika udvidedes således det territoriale handelsområde og selve handelens størrelse for de pågældende landes nationale handelskompagnier i et historisk hidtil ukendt omfang ${ }^{13}$. Den »interne « fordeling af den nye rigdom mellem kolonimagterne afhang på sin side direkte af de nationale hæres og flåders militære succes. Karl den femtes og Philip den andens hære likviderede de norditalienske byers hidtidige handelsherredømme, og da Elizabeth den andens Royal Navy sejrede over Philip den andens Armada (1588) betød det et brud på Spaniens handelsdominans til gunst for England, Frankrigs og Hollands handelsinteresser. På baggrund af Royal Navys overlegenhed på verdenshavene blev det muligt for England at forlænge Navigationsacts (1651), at besejre Holland i tre krige ved slutningen af det 17. århundrede, at grundlægge den verdensomspændende Pax Britannica med fredsstraktaten i Utrecht efter den spanske arvefølgekrig og nedkæmpelsen af Spanien og endelig at fastholde denne med fredsstraktaten i Paris (1763) efter Frankrigs nederlag i syvårskrigen.

\section{Finansvasenet.}

Finansieringen af de stående hære og de talrige krige nødvendiggjorde indførelse af almen beskatning og opbygning af en systematisk finansforvaltning. Frankrigs taille royale, Europas første nationale skat, tjente fra 1440 til financiering af den første regulære hær i Europa, compagnies d'ordonnance.

De forvaltningsreformer, som var så almindelige i absolutismens epoke, havde som deres primære mål en effektivisering af skatteforvaltningen. Beskatningen ramte i første omgang bønderne og byerne, mens adelen stort set kunne holde sig skadesløs. Oveni de almindelige feudalafgifter blev skatterne en så stor belastning for bønderne, at det i adskillige tilfælde resulterede i bondeoprør. Porsnev ${ }^{14}$ har derfor med rette betegnet det absolutistiske monarkis skatter som en »centraliseret feudalpagt«.

13. Jvf. K. Glamann: Der europäische Handel 1500-1750, i Cipolla/Borchardt (red.): 16. und 17. Jahrhundert, op.sit., s. $271 \mathrm{ff}$.

14. Jvf. B. Porsnev: Les Soulévements populaires en Franche de 1623 å 1648, Paris 1963, citeret efter G. Lemarchand: Der Feudalismus im ländlichen Frankreich in der Neuzeit -Versuch einer Charakterisierung, i Kuchenbuch/Michael (red.), op.cit., s. 646. 
For det velhavende borgerskab bød det absolutistiske finansvæsen på talrige muligheder for kapitalakkumulation. Man kan i denne forbindelse nævne skatteforpagtnings-systemet: Store banksyndikater fik i Frankrig monopol på skatteopkrævning og lod ca. 2/3 af de opkrævede skatter gå i egne lommer.

Bourgeoisiet havde også fordel af det system, som hugenotkansleren Sully indførte i 1604, og som gjorde det muligt at købe sig til et offentligt embede. For at $\emptyset$ ge sine indtægter solgte monarkiet således i løbet af det 17. århundrede et stigende antal offentlige embeder, og erhvervelsen af et sådant embede var særdeles indbringende for noblesse de robe, idet den normale korruption indenfor forvaltningen var en god og sikker indtægtskilde for embedsmændene ${ }^{15}$. Endelig udgjorde også långivning til det offentlige en lønnende kapitalinvestering på grund af de meget høje rentesatser for sådanne lån.

Under det absolutte monarki i den vestlige del af Europa fremstod skatteforpagtning, $\mathrm{k} \varnothing \mathrm{b}$ af embeder og långivning til statsmagten for bourgeoisiet som væsentlige kilder for kapitalens forøgelse, men betød samtidigt, at disse klasser blev politisk integrerede i staten gennem deres afhængighed af den absolutistiske stats privilegier, monopolrettigheder og korruptionsvæsen. Denne »feudalisering « af bourgeoisiet viste sig klarest i Frankrig i det 17. århundrede, og svagest i England, hvor bourgeoisiet allerede meget tidligt begyndte at koncentrere sig om kapitalinvesteringer i landbruget, i udenrigshandelen og i manufakturvæsenet.

\section{Merkantilismen.}

For at øge statens finansindtægter, som konstant var for små på grund af de talrige krige i absolutismens Europa, førte samtlige absolutistiske monarkier en politik, som bevidst søgte at fremme og styre økonomien (merkantilisme). For at fremme næringslivet ophævede eller reducerede man stærkt de eksisterende indenlandske produktions- og handelsbarrierer, som f.eks. told og vej- og bropenge, samtidig med, at man forbedrede infrastrukturen (kanal- og vejbyggeri). Absolutismen tog dermed i Europa et stort skridt i retning af et territorialt samlet hjemmemarked. Manufakturvæsenets udvikling blev fremmet gennem statslige privilegier: Udover skattebegunstigelser, offentlige tilskud og kreditter blev manufakturelle virksomheder i regelen tildelt en priviligeret monopolstilling på hjemmemarkedet, ligesom deres eksport blev støttet financielt. Udenrigs $\varnothing$ konomisk fulgte man princippet om den aktive handelsbalance, import af

15. Her kunne man realisere et renteudbytte på 300-400\% om året, jvf. Anderson: Die Entstehung..., op.cit., s. 41. 
færdigvarer blev begrænset eller endog helt forbudt, der blev fastsat høje toldsatser for importvarer for at skade de udenlandske konkurrenter, man forbød eksport af råstoffer samtidig med, at man forsøgte at fremme importen af ikke-substituerbare råstoffer. Denne politikkonception omfattede også en bevidst kolonipolitik og handels- og krigsflådens udbygning. I sine udenrigsøkonomiske relationer var merkantilismen altså temmelig »krigerisk «, jordbesidderklassens territoriale erobringsbestræbelser faldt sammen med den førindustrielle handelskapitals monopolistiske ekspansionsbestræbelser. I det internationale system kunne begge klassers interesser varetages af det absolutistiske monarki ved hjælp af midler som diplomati, alliancer og krige.

\section{Absolutismens historiske "progressivitet .}

Hvad angår forholdet mellem politik og økonomi var absolutismen ikke forskellig fra den middelalderlige feudalisme. De to instanser var stadig »sammensmeltede«, Økonomisk magt havde nu som tidligere den politiske magt som forudsætning, og dette gjaldt såvel for systemets indre som for dets ydre reproduktion. Produktivkræfternes udvikling, udviklingen af handelsog manufakturkapitalen gav ganske vist det feudale herredømmes absolutistiske form væsentlig mere rum end den middelalderlige.

Absolutismen fratog de lokale centre for udøvelse af det politisk $\varnothing$ konomiske herredømme, dvs. den landlige jordbesiddelse og byen, deres magt til fordel for et herredømmecenter på nationalt niveau - suverænitetens parcellering blev overvundet og suveræniteten blev reintegreret i den absolutistiske hersker. Parallelt med denne forskydning af magtcentret fra det lokale til det nationale niveau skete der også en rumlig grænseforskydning. Der skete således en ydre forskydning af den landlige jordbesiddelses og byens grænser, idet de blev sammenfattet i en national grænse. Denne rumlige forskydning gav den oprindelige kapitalakkumulation nye impulser. Der skete en klar reduktion i den indenlandske brug af told og vej- og bropenge, og den væsentligste barriere mod manufakturkapitalens udvikling, produktionens lavsmæssige organisering, blev om ikke ophævet så dog stærkt svækket. Den merkantilistiske manufakturkapital bygger ligesom den lavsmæssige produktion på den politisk formidlede indskrænkning af konkurrencen og adskiller sig dermed fundamentalt fra den senere industrikapital; imidlertid har den priviligerede, monopolistiske manufakturelle produktion i forhold til lavet et langt større aktionsfelt, hvilket giver produktivkraftudviklingen nye impulser ${ }^{16}$.

16. Den middelalderlige feudalismes lav var kun i stand til at udvikle eksportmanufakturen, f.eks. i Flandern og Norditalien, jvf. Pirenne, op.cit., s. $180 \mathrm{ff}$. 
Det nye magtcenter fremmer imidlertid ikke blot manufakturkapitalens udvikling, men giver også handelskapitalen nye manøvrerum. Handelskapitalen profiterer på den ene side af den tendentielle fremvækst af et udvidet territorialt hjemmemarked, og på den anden side - og primært - af de absolutistiske monarkiers kolonipolitik. De middelalderlige byers og byrepublikkers politiske og militære magt var tilstrækkelig stor til at organisere den internationale handel i Nordsø- og Østers $\varnothing$ området (Hansestæderne), mellem Italien og Byzans (Venedig) og mellem Flandern og Norditalien (Champagnemarkederne); erobringen af Afrika, Asien og Amerika krævede imidlertid langt større magtressourcer. Først det absolutistiske monarki, hvis nye militære (stående hær) og financielle (nationalt skattesystem) resourcer oversteg de middelalderlige monarkiers, var i stand til at opbygge koloniimperier og dermed gradvis frembringe verdensmarkedet. Selv om absolutismen ikke overvinder den feudale struktur i forholdet mellem politik og økonomi, og selv om den $\varnothing$ konomiske udvikling stadig er politisk formidlet (og dermed også begrænset), giver herredømmecentrets regionale forskydning fra de lokale autoriteter til det territoriale monarki manufaktur- og handelskapitalen nye bevægelsesmuligheder. Anderson giver følgende beskrivelse af den absolutistiske stats varetagelse af borgerskabets interesser: »På dette stade fandtes imidlertid altid et potentielt område, hvor det var muligt at forene den absolutte stats væsen og program med handels- og manufakturkapitalens faktiske og intenderede handlinger. I den internationale konkurrence mellem adelsklasser, som var årsag til epokens endemiske krige, var varesektorens størrelse indenfor hvert »nationalt « arveland nemlig af afgørende betydning for dets relative militære og politiske styrke. Ethvert monarki havde derfor interesse i bag sin fane og i kampen mod sine fjender at samle rigdom og fremme handelen.... Økonomisk centralisering, protektionisme og oversøisk udbredelse $\emptyset$ gede de senfeudale staters magt og financielle styrke samtidig med, at det begunstigede borgerskabet: Borgerskabet blev således budt bedre betingelser for at gøre profitable forretninger, mens staten på sin side profiterede af de større skatteindtægter, som tilflød dem via den højere gevinst. De maximer om alle $\varnothing$ konomiske foranstaltningers uproblematiske og gnidningsløse samvirke, som opstilles af merkantilismen og proklameres af den absolutistiske stat, modsvaredes konkret af klasseinteressernes periodisk givne sammenfald $\ll^{17}$.

17. Anderson: Die Enstehung..., op.cit., s. 51. 


\section{Om forholdet mellem politik og $\phi$ konomi \\ i den kapitalistiske produktionsmåde.}

\section{Adskillelsen mellem politik og økonomi i det nye samfunds indre.}

Den borgerlige revolutions overvindelse af absolutismen, som i Europa blev fulgt af den kapitalistiske stats opkomst, resulterede i en strukturel ændring af forholdet mellem politik og økonomi i det nye samfundssystems indre. Den borgerlige revolution opløser på landet den feudale udbytningsorden: De materielle feudalafgifter, de feudale tjeneste og feudalherrernes personlige rettigheder afskaffes, hvilket lægger grunden for udviklingen af kapitalistiske produktionsforhold i den agrare sektor. Bondefrigørelsens konkrete form er overalt i Europa til fordel for de store jordbesiddere, de tidligere feudalherrer og storbønderne, og giver dermed anledning til en social differentieringsproces i jordbesiddelse, kapitalistisk forpagtning, kapitalistisk landbrugsbesiddelse og lønarbejde. Samtidig ødelægger det revolutionære bourgeoisi det førkapitalistiske produktions- og byttesystem indenfor industri og håndværk. Lavsordenen ophæves priviligeringen af bestemte virksomheder (manufakturvæsenet) ophæves og næringsfriheden forankres i de nye forfatninger. Med afskaffelsen af de indenlandske told- og vejafgifter fjernes de sidste skranker for udviklingen af et samlet hjemmemarked. Dermed opløser den borgerlige revolution den feudale sammensmeltning af instanserne politik og $\emptyset$ konomi, den adskiller det $\emptyset$ konomiske fra det politiske område. Fra nu af er udbytningsstrukturerne i by og på land primært baseret på de økonomiske forhold, på producenternes adskillelse fra produktionsmidlerne. ${ }^{18}$ Økonomisk magt har nu ikke længere først og fremmest sin rod i politisk herredømme, men i en overlegen konkurrenceposition, som er opnået med $\varnothing$ konomiske midler. Først nu bliver kapitalformen dominerende

18. Analysen bygger på følgende værker: A. Soboul: Die Grosse Französische Revolution, Frankfurt/M. 1979; B. Supple: Der Staat und die industrielle Revolution 1700-1914, i Cipolla/Borchardt (red.): Die Industrielle Revolution, Bd. 3 i serien Europåische Wirtschaftsgeschichte, Stuttgart New York 1976; D. Landes: Der entfesselte Prometheus -Technologischer Wandel und Industrielle Entwicklung in Westeuropa von 1750 bis zur Gegenwart, Köln 1973; H. Böhme (red.): Probleme der Reichsgründungszeit 1848-1879, Köln-Berlin 1972; M. Schlenke (red.): Preussen - Beiträge zu einer politischen Kultur, Reinbek bei Hamburg 1981; C. Hill: Von der Reformation zur industrielle Revolution - Sozial - und Wirtschaftsgeschichte Englands von 1530-1780, Frankfurt/M. 1977; E.J. Hobsbawn: Die Blütezeit des Kapitals, Frankfurt/M. 1980; f. Tomberg: Polis und Nationalstaat - eine vergleichende überbauanalyse im Anschluss an Aristoteles, Darmstadt und Neuwied 1973; K. Polanyi: The great Transformation - Politische und ökonomische Ursprünge von Gesellschaften und Wirtschaftssystemen, Frankfurt/M. 197. 
indenfor samfundsformationen, og denne kommer til at svare til den kapitalistiske produktionsmådes væsen: Industrikapitalen, hvis akkumulation - til forskel fra den før-revolutionære handels- og manufakturkapital - væsentligst beror på økonomisk udbytning, økonomisk konkurrence og produktivkraftudvikling.

Den politiske instans bliver altså løst fra produktionsforholdene og overtager i separat form bestemte funktioner til sikring af den nye samfundsstruktur. I forhold til den indre фkonomi overtager den unge borgerlige stat primært tre opgaver: Institutionel fremme af de nye produktionsforhold, udbygning af infrastrukturen og støtte til nye industrigrene. Afhængigt af udviklingsniveau viser der sig her iøjnefaldende forskelle mellem de enkelte europæiske stater. I England havde man allerede i kølvandet på den glorværdige revolution i det 17. århundrede indført et fælles mønt-, skatte- og toldsystem, ligesom man havde tilpasset handelsretten til de nye produktionsforhold. På grund af industrialiseringsforspringet i forhold til de $\emptyset$ vrige europæiske stater, som først fra slutningen af det 18. århundrede gradvist overvandt feudalismen, kunne den engelske stat vise større tilbageholdenhed, både hvad angår infrastrukturen (f.eks. privat jernbanebyggeri) og støtte til nye industrigrene. Med den franske revolution begyndte i Frankrig en institutionel sikring og fremskyndelse af den kapitalistiske produktionsmådes udvikling: Udover den allerede beskrevne ophævelse af de feudale strukturer indførte den nye stat et fælles system for mål og vægt, den reformerede handels- og erhvervsretten og den søgte at fremme dannelsen af et fælles fransk nationalsprog. I det 19. århundrede begyndte den franske stat at tillægge infrastrukturpolitikken en meget stor betydning. Her, hvor jernbanen i modsætning til England blev indført før den industrielle revolution, engagerede staten sig dybt i mobiliseringen af de nødvendige resourcer for jernbanevæsenets opbygning. Indtil midten af det 19. århundrede skete der en hastig udbygning af de franske jernbaner ved hjælp af blandede statslige-private selskaber (især under borgerkongen Louis Philippe). I modsætning til, hvad der var tilfældet i f.eks. Belgien og Preussen, støttede den franske stat i det 19. århundrede ikke nye industrigrene gennem direkte deltagelse, men kun gennem indirekte foranstaltninger. I denne forbindelse kan man i første række nævne fremme af den tekniske udvikling gennem Ecole Polytechnique og institutionel støtte til teknologi-import fra England og USA.

I Tyskland og Italien var bourgeoisiet indtil sidste trediedel af det 19. århundrede for svagt til at kunne tilkæmpe sig en kapitalistisk enhedsstat under dets egen ledelse. Den nationale opsplittelse bremsede den industrielle udvikling. Det er i denne sammenhæng interessant, at den absolutistiske 
presusiske stat indtil grundlæggelsen af det Tyske Rige var i stand til at tilpasse sig den kapitalistiske produktionsmådes udvikling gennem reformer. For at varetage sine politiske interesser i Tyskland og Europa var den preussiske stat tvunget til at understøtte industrialiseringen og dermed kapitaliseringsprocessen. Uden en passende $\varnothing$ konomisk baggrund ville den have været sine politiske modstandere udenrigspolitisk og først og fremmest militært underlegen. I reformfasen indførte Preussen således næringsfrihed (1810), og med »bondefrigørelsen« (1811-16) fremmedes desuden den kapitalistiske omformning af de preussiske godser ${ }^{19}$. I 1818 ophævedes de indenlandske toldafgifter, og i 1834 oprettedes et preussisk domineret toldforbund, som forvandlede fire femtedele af det tyske territorium til en frihandelszone ${ }^{20}$. Fra 1847 fremskyndede Preussen jernbanebyggeriet og ydede støtte til nye industrigrene gennem statslig deltagelse eller gennem direkte statslige virksomhedsetableringer f.eks. indenfor jern- og kulindustrien.

De borgerlige stater og - under pres - visse senfeudale stater forvandlede således i deres indre forholdet mellem instanserne politik og økonomi og skabte herigennem en ny samfundsstruktur. Den separate politiske instans begrænsede fra nu af sine interventioner i $\varnothing$ konomien til institutionelle garantier for den kapitalistiske produktionsmåde, udvikling af infrastrukturen og - omvendt proportionalt med udviklingsniveauet - opbygning af nye industrigrene.

\section{Reproduktionen af sammensmeltningen af politik og økonomi i form af nationalstaten.}

Med den borgerlige revolution sker der kun en forvandling af nationalstaternes indre samfundsstruktur, hvorimod de eksternt principielt fastholder den førkapitalistiske sammensmeltning af instanserne politik og økonomi. Mens den borgerlige stat i vidt omfang trækker sig ud af kapitalernes konkurrence på de nationale hjemmemarkeder, intervenerer den stadig direkte i kapitalernes pris- og afsætningskampe på de internationale markeder; denne intervention sker i form af told-eksportpræmier, importforbud, kontingentering etc. Den borgerlige stat knytter altså umiddelbart an til de nationale grænser, som var opstået under absolutismen - ja, den forstærker endog disse skranker, idet den giver nations-begrebet et socialt indhold og stabiliserer dermed nationalstaten. Kapitalen, den

19. Brandt m.fl., op.cit., s. 99ff.; I. Mieck: Zielsetzung und Entwicklung der preussischen Reformen, i Schlenke (red.), op.cit., s. $181 \mathrm{ff}$.

20. Jvf. W.O. Henderson: Die Rolle Preussens bei der wirtschaftlichen Einigung, i Schlenke (red.), op.cit., s. $197 \mathrm{ff}$. 
verdenshistoriske leveller, som efter sit begreb nedriver enhver politisk, social og økonomisk skranke, som står i vejen for dens udvikling, knytter i sin opkomst an til de givne nationalgrænser uden at overvinde dem. Denne modsigelse mellem kapitalens logik og historie skal udelukkende forstås historisk-genetisk. Den har sin rod i den politiske og socialøkonomiske udviklings usamtidige karakter ved overgangen fra feudalismen til kapitalismen.

Den kapitalistiske revolution sker først i England og Holland, derefter følger Frankrig, så Preussen og til sidst med stor forsinkelse Italien og Rusland. Denne usamtidighed i den økonomiske udvikling tvinger de stater, hvis udviklingsproces ligger efter Englands, til at fastholde en udenrigs økonomisk beskyttelse af deres underlegne industrier. I betragtning af den britiske overlegenhed ville det for de nye industristater have været rent selvmord at indføre et hjemmemarked omfattende hele Europa. For en borgerligrevolutionær stat, som den franske efter 1798, var det trods det ellers radikale brud med absolutismens $\emptyset$ konomiske politik en eksistentiel nødvendighed at fastholde merkantilismens udenrigs $\varnothing$ konomiske politik.

Ikke blot de europæiske staters forskellige $\emptyset$ konomiske udviklingsniveau, men også den politiske udviklings usamtidighed, er med til at konsolidere de grænser, som første gang vandt fodfæste under absolutismen. Det borgerlige England i det 17. og 18. århundrede adskiller sig fra det feudale kontinentaleuropa ved udviklingen af en selvstændig politisk og $\varnothing$ konomisk kultur. Med den franske revolution og Napoleons-krigene oplever nationalbevidstheden sin første kontinentale opblomstring i Europa. Med afskaffelsen af de 3 stænder, med borgernes retslige ligestilling, med ophævelsen af kirkens privilegier, med begrebet om folkesuverænitet bereder den franske revolution politisk og socialt vejen for et fælles samfund og en enig nation.

Skønt revolutionen forråder enheden gennem den forfatningsretslige garanti for privatejendommen og undergravningen af folkesuveræniteten gennem et valgretssystem baseret på formueansættelse, så skaber den alligevel i sin kamp mod den feudale orden og med afskaffelsen af stænderne, som vækker håb om social lighed i det nye samfund, en voksende national bevidsthed i befolkningen. »Efter 1789 fik ordet nation en ny værdi, som viste sig i den begejstrede jubel og de spontane fælles bevægelser, som gav liv til tro og håb. Nationen: Det var fællesskabet, massen af borgere sluttet sammen i én eneste blok; der fandtes ikke længere stænder og klasser; alt hvad der var fransk tilhørte nationen $\ll^{21}$.

21. Soboul, op.cit., s. 551. 
Napoleons-krigene styrker den franske nationalbevidsthed betydeligt, mens de alle andre steder i det besatte Europa skaber en nationalistisk reaktion, først og fremmest i Tyskland. Preussens nederlag ved Jena og Auerstaedt (1806) var ikke blot et sidste stød til den preussiske reformpolitik, men fremmede også udviklingen af det tyske borgerskabs nationale bevidsthed ${ }^{22}$ og lagde grundstenen til den tyske nationalliberalisme. De borgerlige staters usamtidige udvikling - den tidlige borgerlige revolution i England, det revolutionære Frankrig isolerede stilling i det kontinentale Europa, den forsinkede samling af Tyskland og Italien, som først satte sig igennem i krige mod andre stater - resulterede i en usamtidig udvikling af nationalstaterne, en usamtidighed, som forstærkede nationernes politiske, $\varnothing$ konomiske og ideologiske rivaliseringer og fik den nationale tankes partikularistiske aspekt til at vinde overhånd i forhold til dens kosmopolitiskuniversalistiske aspekt.

Modsigelsernes overdeterminering ${ }^{23}$ i den borgerlige revolutions epoke i Europa, den usamtidige udvikling i de økonomiske, politiske og ideologiske forhold mellem de europæiske stater, betød en fastfrysning af nationalstatsstrukturen og en erodering af bourgeoisiets kosmopolitisme. Den borgerlige revolution standsede således på halvvejen: Den skabte ganske vist i nationalstaterne indre produktionsforhold og en strukturel relation mellem instanserne politik og $\varnothing$ konomi, som var i overensstemmelse med kapitalens behov; på den anden side blev den førkapitalistiske sammensmeltning af politik og $\varnothing$ konomi fastholdt i det internationale system. Revolutionen var ikke i stand til at gennemsætte en statsstruktur, som svarede til kapitalens kosmopolitiske tendens: Nemlig den forenede verdens stat.

\section{Nationalstaten og de økonomiske love på det kapitalistiske verdensmarked.}

Indtil nu har vi fremstillet den historiske udvikling, som resulterede i kapitalens nationalstatslige struktur. Vi skal herefter beskæftige os med spørgsmålet, om man overhovedet kan tale om økonomiske lovmæssigheder i forbindelse med kapitalernes konkurrence på verdensmarkedet. Nationalstatens muligheder for at gribe ind i den internationale konkurrence i form af toldreguleringer, kontingentering, forbud, ændringer i valutakursen etc. rejser spørgsmålet om værdilovens status i de internationale $\varnothing$ konomiske

22. Jvf. T. Schieder: Der Nationalstaat in Angriff und Verteidigung, i Böhme, (red.) op.cit., s. 402ff. og W. Sauer: Das Problem des deutschen Nationalstaats, i Böhme (red.), op.cit., s. 448ff.

23. Om dette begrebs betydning se L. Althusser: Für Marx, Frankfurt/M. 1968. 
relationer. I besvarelsen af dette spørgsmål skal vi starte bagfra, idet vi først unders $\varnothing$ ger, hvilke lovmæssigheder, der strukturerer nationalkapitalernes internationale konkurrence, når nationalstaten begrænser sine indgreb i verdensmarkedsrelationerne til et nødvendigt minimum. Dette interventionsminimum, som er en nødvendig følge af selve kapitalens nationalstatslige strukturering, også når der ikke sker direkte indgreb i pris- og afsætningskonkurrencen gennem toldregulering, kontingentering etc., består i de svingninger i de indbyrdes valutakurser, som følger af ændrede konkurrencerelationer mellem forskellige nationalstater. Den vekselkurs-struktur, som med nødvendighed må følge af nationalstatens eksistens, indebærer en væsentlig modifikation af kapitalkonkurrencen på verdensmarkedet. Værdilovens modificerede gennemslag på verdensmarkedet vil senere blive fremstillet mere detaljeret $\mathrm{i}$ afsnittene om den internationale handel og de internationale kapitalbevægelser. Vi skal derfor her kun give en kort sammenfatning af de af dette teorems følger, som er af relevans for den her undersøgte problemstilling:

1) Der sker en modificering af kapitalkonkurrencen på verdensmarkedet, idet vekselkursstrukturen berøver de højere udviklede nationale $\varnothing$ konomier deres surplusprofit-position, samtidig med at den gør det muligt for de svagtudviklede nationalkapitaler at fastholde deres konkurrenceposition (værdilovens beskyttelses- og udligningsfunktion på verdensmarkedet.

2) Kapitalkonkurrencen konstituerer en international arbejdsdeling på grundlag af komparative omkostningsstrukturer, som fremmer produktivkraftudviklingen i alle verdenshandelsnationer.

3) På grund af den lov for kapitalkonkurrencen, som blev beskrevet under pkt. 1, kan de svagtudviklede økonomier på verdensmarkedet omsætte deres akkumulationsfordele (kapitalens lavere organiske sammensætning, højere gennemsnitsprofitrate) i en højere akkumulationsrate end de mere udviklede $\varnothing$ konomier. Den ulige udvikling er derfor i international målestok til fordel for de svagere udviklede nationer ${ }^{24}$.

Disse 3 lovmæssigheder for verdensmarkedskonkurrencen $\mathrm{g} \emptyset \mathrm{r}$ det klart, hvorfor det, selv når de forskellige nationale kapitaler har forskelligt udviklingsniveau, ikke blot er muligt, men også til fordel for samtlige deltagere i den internationale vareudveksling, hvis nationalstaternes indgreb i den internationale kapitalkonkurrence begrænses. På verdensmarkedet virker værdiloven ikke blot som en beskyttelse af

24. De nævnte sammenhænge mellem ulige udvikling og, verdensmarkedet gælder kun for landene $\mathrm{i}$ »den tredje verden« med visse forbehold, jvf. afsnittet om underudviklingsteorien. 
de svagere udviklede nationale kapitaler; den giver dem også produktivitetsfordele indenfor den internationale arbejdsdeling, ligesom de får mulighed for at holde et højere akkumulationstempo end de mere udviklede nationer. Dette giver de mere produktive brancher i såvel de rige som de fattige nationer en interesse $i$ en liberalisering af verdensmarkedskonkurrencen. De eneste, som har interesse i protektionistiske nationalstatslige indgreb i den internationale konkurrence, er set ud fra disse lovmæssigheder de mindre produktive brancher i samtlige verdens handelsnationer.

Som fiktive nationale totalkapitalister handler nationalstaterne rationelt, hvis de holder deres interventioner i den internationale konkurrence på et minimum. Vort oprindelige spørgsmål må derfor besvares således: Under forudsætning af, at nationalstaten ikke intervenerer på verdensmarkedet, er det muligt at konstatere særlige lovmæssigheder for kapitalkonkurrencen. På trods af den principielle sammenfletning af instanserne politik og økonomi i de nationale kapitalers konkurrence er det ikke blot nyttigt, men også nødvendigt at analysere disse lovmæssigheder, idet nationalstatssystemet samlet kan drage fordel af deres gennemsættelse, dvs. af en liberaliseringspolitik.

Den mulighed, at nationalstaten kan trække sig tilbage fra kapitalens verdensmarkedsrelationer, afslører den væsentlige forskel mellem feudalisme og kapitalisme, hvad angår det strukturelle forhold mellem politik og økonomi i det internationale system. Den tese, vi tidligere har formuleret, nemlig, at det kapitalistiske nationalstatssystem i sig bærer den førkapitalistiske sammensmeltning af politik og økonomi, skal nu nærmere specificeres. I verdenskapitalens opgangsfaser kan den økonomiske instans opnå en autonomi i forhold til det politiske felt som kun begrænses af den tidligere nævnte minimalskranke for nationalstatslig intervention. Denne autonomiseringstendens for den $\emptyset$ konomiske instans, som - under de nævnte betingelser og begrænsninger - også på verdensmarkedet ligger immanent i den kapitalistiske produktionsmåde, markerer forskellen i forhold til den feudale produktionsmåde. Under feudalismen er områderne politik og økonomi principielt sammenflettede både i systemets indre og ydre reproduktion, og økonomiens autonomibestræbelser modsiger denne produktionsmådes strukturlove. Det er ikke nogen historisk tilfældighed, at den merkantilistiske teori begriber den internationale handel som et nulsum-spil, der spilles med politiske ressourcer, og at det først er den klassiske politiske $\emptyset$ konomi, som med hjælp af den ricardianske udenrigshandels-teori udfolder frihandelsdoktrinen. Selv om instanserne politik og økonomi er sammensmeltede i såvel den feudale som den kapitalisti- 
ske produktionsmådes ydre reproduktion, giver de to produktionsmåders forskellige indre struktur anledning til tydelige divergenser i dette forholds konkrete udformning.

Det internationale handelssystems historie efter starten af den europæiske industrialisering viser klart, at liberalismen kun praktiseres i perioder præget af en gunstig kapitalakkumulation i de vigtigste verdenshandelsnationer. I første halvdel af det 19. århundrede dominerer blandt de unge industristater en beskyttelsestold-politik, som først og fremmest er rettet mod den frihandelsorienterede, dominerende britiske industrikapital. I en kort periode i 60'erne sker der en vis afvikling af protektionismen.

Således indgås der adskillige toldsænkende bilaterale handelsaftaler mellem Storbritannien, Frankrig, Belgien, Italien og det tyske toldforbund, hvor man allerede havde indført en mestbegunstigelses-klausul ${ }^{25}$. Denne liberaliseringsproces finder sin afslutning i sidste halvdel af halvfjerdserne, hvor den afløses af en toldmurspolitik; dette sker under indtryk af den depressive tendens, som præger akkumulationsprocessen i den sidste fjerdel af det 19. århundrede.

Tysklands og Englands økonomiske vanskeligheder i kølvandet på første verdenskrig førte sammen med en fejlagtig ansættelse af pundets og francens værdi til en stagnation i den europæiske handel og umuliggjorde en tilbagevenden til frihandel. Selv de frihandelsorienterede englændere indførte et importtoldsystem til beskyttelse af $»$ nøgleindustrierne $\ll^{26}$. Verdenskrisen fra 1929 til 1932 førte til en næsten fuldstændig opløsning af verdensøkonomien. Tysklands insolvens udløste en international bølge af devalueringer og valutakontrolforanstaltninger, protektionismen florerede, Storbritannien og Frankrig indførte toldpræferencesystemer i forhold til deres respektive kolonier. På trods af den konjunkturelle genoplivning nåede den europæiske handel i 1937 kun op på 79\% af niveauet i 1929. I perioden 1929-39 skete der en halvering af den indbyrdes handel mellem Storbritannien, Frankrig og Tyskland ${ }^{27}$.

Efter anden verdenskrig udløste den verdensomspændende vækstperiode frem til krisen i 1974/75 den hidtil største liberaliseringsbølge i det kapitalistiske verdensmarkeds historie. Bretton-Woodsystemet, dvs. indførelse af fuld valutakonvertabilitet og et internationalt støttesystem i tilfælde af

25. Jvf. Landes, op.cit., s. $186 \mathrm{ff}$ samt Henderson, op.cit., s. $204 \mathrm{ff}$.

26. Jvf. J. Pinder: Europa in der Weltwirtschaft 1920-1970, i Cipolla/Borchardt (red.): Die europäischen Volfswirtschaften im 20. Jahrhundert, Bd. 5 af serien »Europäische Wirtschaftsgeschichte, Stuttgart 1980, s. 377ff.

27. Pinder, op.cit., s. 387. 
betalingsbalance-kriser, tilvejebragte forudsætningerne for verdenshandelens liberalisering. GATTsystemet indførte mestbegunstigelses-klausulen på verdensplan og førte gennem Dillon-, Kennedy- og Tokioforhandlingsrunderne til en betydelig reduktion af toldskrankerne. Fællesmarkedet og den europæiske frihandelszone betød, at der i det kapitalistiske Europa blev indført toldfrihed for industrivarer.

På grundlag af et enestående akkumulations-boom kunne de udviklede kapitalistiske nationalstater drage den politiske lære af verdensmarkedets sammenbrud i 30'erne. Valuta- og handelssamarbejdet betød, at den kapitalistiske verdenshandel kunne vokse væsentligt hurtigere end den kapitalistiske verdensproduktion. Den verdensomspændende krise fra 1974/75 har imidlertid undergravet denne samarbejds- og integrationstendens. Talrige aftaler mellem USA og Fællesmarkedet indbyrdes og med tredielande om eksportbegrænsninger for bil-, stål-, værfts- og elektroniksektoren, en grasserende subventionspraksis i forhold til kriseramte brancher (først og fremmest stål) samt et stigende antal ikke-aftalte handelshindringer har lidt efter lidt undergravet GATT-systemet. Fra 1981 er verdenshandelen begyndt at falde.

Denne korte historiske skitse af protektionisme- og liberaliseringsfaserne på verdensmarkedet viser den nationalstatslige interventionspolitiks store afhængighed af akkumulationscyklen. Kun i perioder med højkonjunktur er det muligt for nationalstaterne at trække sig ud af den internationale kapitalkonkurrence; depressionsperioder resulterer derimod i en kriseeksternaliserings-politik, dvs. et forsøg på i krisen gennem en beggar-my-neighbour-politik at holde sin egen kapital mest mulig skadesløs på bekostning af naboerne. I verdenskapitalens opgangsfaser kan de kapitaler og lønarbejdere, som trues af arbejdsdelingens love, vandre til brancher, som er i vækst, og derigennem bidrage til en friktionsløs strukturudvikling. I krisetider derimod vil rentabilitetsfaldet, overproduktionstendensen, tilintetgørelsen af kapital og arbejdspladser - altså krisemomenter, som omfatter hele økonomien - virke som skranker for den internationale strukturudvikling. Da flere industribrancher og storforetagender for det meste samtidig er truet af den almene krise og den internationale strukturudvikling, kan det nationale statsapparat, som er underkastet nationale legitimeringsprocesser, ikke længe holde stand overfor presset for at få indført protektionisme, og det på trods af den indsigt, at den internationale krise herigennem vil blive skærpet. Det er altså ikke kun økonomiske (værdiøgningsinteresser), men også politiske (legitimeringsproblemer) momenter, som i krisen bidrager til protektionismens modstandsdygtighed. 
I kriseperioder er tilbagefaldet til en udenrigsøkonomisk merkantilisme et slående udtryk for den særlige forskel, som eksisterer mellem politik$\varnothing$ konomi-relationen indenfor og udenfor nationalstatens grænser. Mens nationalstaten indadtil er gået over til at føre udbudspolitik, altså statens tilbagetrækning fra $\varnothing$ konomien, praktiserer den samme stat - trods en divergerende ideologi - det modsatte på internationalt niveau: I stigende grad og med forskellige midler intervenerer nationalstaten protektionistisk i kapitalens konkurrence.

\section{Den borgerlige nationalstats inerti.}

Vi har nu vist, hvorledes der med baggrund i de borgerlige samfunds usamtidige udvikling sker en sammensmeltning af den politiske og $\emptyset$ konomiske instans i form af nationalstaten, og hvorledes kapitalens nationalstatslige eksistens resulterer i en særlig fremtrædelsesmåde for værdiloven i det internationale system. Til slut skal vi nu kort undersøge, hvorfor det borgerlige samfund endnu 2-3 århundreder efter sin politiske konstituering ikke er i stand til at gennemsætte en struktur i forholdet mellem politik og økonomi, som er i overensstemmelse med kapitallogikken, også på internationalt niveau. For de momentant forekommende kriseperioders vedkommende er årsagerne til nationalstatens inerti ret indlysende.

Vi har så tilbage at undersøge, hvilke chancer der i verdenskapitalens opgangsfaser er for at realisere overnationaliserings-bestræbelserne i relationerne mellem nationalstaterne. Faktisk har man i fællesmarkedet kunnet etablere en toldunion, og i 70'erne er der endog blevet gjort alvorlige fors $\emptyset \mathrm{g}$ på at nå frem til en $\emptyset$ konomisk union og en valutaunion. Hvis vi går ud fra modifikations-teoremet, kan den opstillede problemstilling besvares på følgende måde: Så længe nationalkapitaler med forskelligt udviklingsniveau står overfor hinanden på verdensmarkedet, er de svagere udviklede nationer ubetinget henvist til beskyttelses- og udligningsfunktionen, hvilket implicerer kapitalens nationalstatslige eksistensform. Overnationaliseringsbestræbelserne er ganske vist i de højere udviklede nationale kapitalers interesse, men kan af de lavere rangerende nationer kun accepteres $\mathrm{i}$ form af frihandelszoner eller toldunion. Denne type af integrationsformer garanterer, at den nationalstatslige minimalintervention i den internationale konkurrencekamp bevares, nemlig valutarelationernes beskyttelsesfunktion Videregående integrationsprocesser - f.eks. økonomisk union eller valuta-union - vil derimod resultere i ulige konkurrenceforhold til fordel for de mere produktive nationalkapitaler og vil derfor ikke være acceptable for mindre udviklede nationer. Fællesmarkedets erfaringer med 
de forskellige fors $\emptyset \mathrm{g}$ på i 70'erne at realisere tankerne om en $\emptyset$ konomisk union og en valutaunion, og dets erfaringer med det endnu fungerende europæiske valutasystem, viser, at selv beskedne fors $\emptyset \mathrm{g}$ på et valutasamarbejde må mislykkes, når kapitalakkumulationen i de deltagende lande befinder sig på forskelligt niveau.

Modsigelsen mellem kapitalens nationalstatsform og internationaliseringstendens lader sig altså endnu - næsten 300 år efter den engelske og næsten 200 år efter den franske revolution - ikke løse som følge af de enkelte nationalkapitalers forskellige udvikling. I en udviklingsfase, der som den nuværende er præget af en omfattende handels- og kapitalsammenfletning, hvor den voksende konjunkturelle afhængighed mellem nationalstaterne indbyrdes i sig selv kræver en internationalisering af statsfunktionerne, skærpes den nævnte modsigelse betydeligt. Dette viser sig især i den aktuelle verdenskrise, som ikke alene forværres af den tilbagevenden til merkantilismen, som udspringer af nationalstatsligheden, den bliver også sværere at overvinde. I den periode, der er gået siden de borgerlige revolutioner, har borgerskabet manglet evnen til også i det internationale system at gennemsætte en strukturering af instanserne politik og økonomi, som er i overensstemmelse med kapitalens logik. Dette har, især med den verdensomspændende akkumulationskrise, skærpet den kapitalistiske produktionsmådes økonomiske og politiske modsigelser.

Forholdet mellem politik og фkonomi

på det kapitalistiske verdensmarked

som det fremstår i den løbende debat

- Kritiske bemarkninger til alternative

forklaringsmodeller.

\section{Nationalstaten som kapitalreproduktionens forudsætning (Olle/Schöller).}

Olle/Schöller giver i deres arbejde, stærkt inspireret af en tidlig artikel af Heide Gerstenberger ${ }^{29}$, en fremstilling af den snævre sammenhæng mellem udviklingen af det kapitalistiske verdensmarked, de borgerlige nationalstaters opståen og akkumulationens gennemsættelse på grundlag

28. W. Olle/W. Schoeller: Weltmarkt, nationale Kapitalreproduktion und Rolle des Nationalstaats, i Volkhard Brandes m.fl. (red.): Handbuch 5 - Staat, Frankfurt/M. 1977, s. 372ff.

29. H. Gerstenberger: Zur Theorie der historischen Konstitution des bügerliches Staates, i Prokla nr. 8/9, West-Berlin 1973, s. $207 \mathrm{ff}$. 
af kapitalistiske produktionsforhold. Deres centrale tese lyder: »Kapitaliseringsprocessen forudsætter ydre markeder, og erobringen af disse i konkurrence med andre historisk eksisterende magter - forudsætter allerede nationalstatens funktioner, før den borgerlige stat formelt har konstitueret sig. $\ll^{30}$

Allerede Heide Gerstenberger havde i sin teori om den borgerlige stats konstituering gjort sig til talsmand for den anskuelse, at kampen om ydre markeder har været den væsentlige årsag til den borgerlige stats konstituering. Ved hjælp af denne tese forsøgte hun ikke blot at forklare den absolutistiske centralmagts udvikling ved begyndelsen af nyere tid, men også dens krigspolitik, finanspolitik og økonomiske politik. Efter denne opfattelse udviklede den borgerlige stat sig i sine grundlæggende $\varnothing$ konomiske funktioner og organisationsformer i den merkantilistiske periode; den konstituerede sig altså materielt før den gennem den borgerlige revolution også fik en forfatningsmæssig forankring ${ }^{31}$.

På grundlag af denne analyse af den borgerlige nationalstats genese drager Olle og Schöller nogle centrale konklusioner angående det kapitalistiske verdensmarkeds nuværende struktur. Efter deres opfattelse kan kapitalens tendentielt voksende internationalisering ikke overvinde nationalstaten. På samme måde som nationalstaten var en historisk forudsætning for de nationale totalkapitalers konstitueringsprocesser, vil der også i dag kræves en overnational stat for at udvikle en international totalkapital. »Den tese, at der foregår en omfattende udligning og internationalisering af kapitalreproduktionen, som materielt undergraver nationalstaten, er imidlertid problematisk, ikke blot på grund af sit mangelfulde empiriske grundlag, men også ud fra metodologiske overvejelser. Selv tendensen til en sådan udvikling ville historisk - analogt med den nationale totalkapitals konstitueringsproces som resultat af nationalstatslige funktioner - forudsœtte en universel, overnational statslighed, som kunne påtage sig rollen som »fødselshjælper« for en »internationaliseret « kapitalreproduktion. Ud fra disse overvejelser vil vi afvise den tese, som siger, at der sker en tendentiel overvindelse af nationalstaten gennem en $\phi k o n o m i s k$ mekanisme. $\aleph^{32}$ Analysen bør derfor i stedet beskæftige sig med, hvilke nationalstats-funktioner, der har udviklet sig som udtryk for den produktive kapitals internationaliseringsprocesser.

30. Olle/Schoeller, op.cit., s. 378.

31. Gerstenberger, op.cit., s. 225.

32. Olle/Schoeller, op.cit., s. 394. 
Olle og Schöllers analyse af forholdet mellem verdensmarked og nationalstat bygger på adskillige fejlfortolkninger, hvad angår kapitalismens historiske genese ${ }^{33}$ :

1) De forstår primært den absolutistiske stat som en borgerlig stat, hvis struktur (centralisering, stående hær, finansreform, merkantilisme) vokser ud af verdensmarkedskonkurrencens betingelser.

2) De absolutte monarkiers krige betragtes derfor i første række som handelskrige og ikke som primært udtryk for de feudale staters territoriale ekspansionsbestræbelser.

3) De overser den strukturelle forskel mellem handels- og manufakturkapitalen i den absolutistiske periode og industrikapitalen i det borgerlige samfund.

4) I denne betragtningsmåde udjævnes også den afgørende forskel mellem den feudale absolutisme og det borgerlige samfund, hvad angår forholdet mellem politik og økonomi.

På baggrund af disse misforståelser i den historiske analyse er den analogi, som Olle og Schöller opstiller mellem den kapitalistiske produktionsmådes genese og den aktuelle nationalstats-internationaliserings-problematik, ikke særlig opklarende. Metodologisk er det endvidere yderst problematisk at slutte fra analysen af en bestemt fase i den kapitalistiske udvikling (her: forholdet mellem stat og kapital i den kapitalistiske produktionsmådes genese) til en anden historisk situation (her: forholdet mellem nationalstat og kapitalens internationalisering i dag). Olle og Schöller giver implicit resultaterne af deres historiske undersøgelse en begrebsmæssig-logisk status og sammenblander dermed det konkret-historiske og det abstrakte analyseniveau. Da nationalstaterne ikke kan begrundes ud fra kapitalens logik, vil andre faser i den kapitalistiske produktionsmåde kunne frembringe et andet forhold mellem nationalstat og kapital. Olle og Schöllers forsøg på at begrunde nationalstatens kontinuitet eller reproduktionstendens, med historiske analogislutninger, er derfor - helt bortset fra analysens historiske fejltagelser - metodisk utilladelig.

\section{Nationalstaten som middel i den internationale kamp om merproduktet (Tilla Siegel).}

Tilla Siegels analyse af kapitalens verdensmarkedsbevægelse danner en klar modpol til vort eget modificerings-teorem, og den er da også formuleret som et bevidst fors $\emptyset \mathrm{g}$ på at afgrænse sig i forhold til den teoretiske position, vi selv tager udgangspunkt i. De centrale forskelle relaterer sig

33. H. Gerstenberger har i mellemtiden revideret sin tidligere position, jvf. H. Gerstenberger: Vom Ursprung bürgerlicher Staaten, i Prokla nr. 47, West-Berlin 1982, s. $119 \mathrm{ff}$. 
for det første til den internationale konkurrences $\varnothing$ konomiske lovmæssigheder (jvf. andet afsnit i den foreliggende artikel), og for det andet til forholdet mellem politik og økonomi på det kapitalistiske verdensmarked. »Den marxistiske verdensmarkedsdiskussion befinder sig i en økonomisk blindgyde. Dette skyldes, at man overbetoner unders $\emptyset$ gelsen af kapitalismen som økonomisk system, og denne undersøgelse har ovenikøbet for det meste begrænset sig til delaspekter, som - revet ud af deres sammenhæng - har måttet holde for som forklaringer på systemets samlede dynamik. $\ll^{34}$

I sit fors $\varnothing \mathrm{g}$ på at forstå relationen mellem politik og økonomi på verdensmarkedet bevæger Tilla Siegel sig på to planer: På den ene side betragter hun kapitalens almene tendens som en universel tendens, på den anden side undersøger hun følgerne af kapitalens historisk fremvoksede nationalstatslige strukturering. Hun er af den opfattelse, at det ud fra den kapitalistiske produktionsmådes logik er verdensmarkedet og ikke nationalstaten, »som må betragtes som det normale for den kapitalistiske produktion og cirkulation « ${ }^{35}$. Hun vil vise, at man ikke på det rent $\varnothing$ konomiske analyseniveau kan konstatere nogen modifikation af værdiloven på verdensmarkedet, at værdiloven som sådan har en universel betydning. Først når man tager hensyn til den politiske instans, altså til nationalstatsstrukturen, viser der sig en modifikation af kapitalkonkurrencen i sammenligning med hjemmemarkedet. Hendes centrale anklage mod den hidtidige marxistiske verdensmarkedsteori er, at den har negligeret det politiske moments betydning for kapitalens verdensmarkedsanalyse: »I den internationale konkurrence træder kapitalerne ikke blot op overfor hinanden som slet og ret kapitaler, men derimod som kapitaler fra bestemte nationer med forskellig økonomisk, politisk og militær magt. Gennem kapitalismens opdeling i nationer sker der altså en helt afgørende modifikation af dette samfunds almene karakteristika: Idet politik bliver en integreret bestanddel af den internationale konkurrence, er det ikke længere kun $\varnothing$ konomiske (markedsmekanistiske) betingelser, som regulerer producenternes relationer $\aleph^{36}$. Det paradoks, »at både verdensmarked $o g$ nation er forudsætning for og resultat af den kapitalistiske produktion $\ll^{37}$, løser sig for Tilla Siegel ved, at kapitalen indeholder

34. T. Stiegel: Kapitalismus als Weltsystem - Methodische Probleme einer marxistischen Analyse des Weltmarktes, Frankfurt/New York 1980 s. 233.

Et afsnit fra bogen er oversat til dansk og under titlen »Værdilov og verdensmarked « bragt i Kurasje 29, s. 39-62.

35. Siegel, op.cit., s. 16.

36. Siegel, op.cit., s. 17f.

37. Siegel, op.cit., s. 177. 
et herredømmeforhold, som har antaget national form. På det internationale niveau implicerer kapitalens ekspansion derfor samtidig en mellemnational kamp mellem herskende klasser om merproduktet.

Med sin centrale tese, at kapitalkonkurrencen på verdensmarkedet må begrundes politisk og ikke økonomisk, befinder Tilla Siegel sig i en dobbelt blindgyde. Som vi skal se om lidt, analyserer hun på den ene side metodisk den internationale værdidannelses processer og dermed de internationale handelsrelationer på samme niveau som den indenlandske kapitalkonkurrence, verdensmarkedet sætter altså ingen nye bestemmelser. På den anden side har den politiske instans en sådan vægt i hendes verdensmarkedsanalyse, at det faktisk er overflødigt at lede efter økonomiske lovmæssigheder i den internationale konkurrence. Tilla Siegel hævder ganske vist, at man også på verdensmarkedet må udlede politikken af økonomien: »Den må nemlig grundlæggende tjene kapitalens værdiøgning; den sætter imidlertid selv igen betingelser for det $\varnothing$ konomiske, den bliver selv $\varnothing$ konomisk kraft. $\ll^{38}$ I dette perspektiv vil det kun være meningsfyldt at analysere den nationale kapitals værdiøgningsinteresse, dvs. den interesse, som skjuler sig bag nationalstatens politik. Ifølge Tilla Siegel er det ikke muligt at finde frem til økonomiske lovmæssigheder, som regulerer kapitalens internationale kamp; selv denne konkurrences simpleste kategorier, pris og vare, er politisk bestemt: »Denne modifikation består $\mathrm{i}$, at princippet om de absolutte prisfordele ganske vist har gyldighed for det kapitalistiske verdensmarked, men at disse prisfordele ikke alene bestemmes af magtfrie markedsmekanismer. Spørgsmålet om hvor og hvad, der produceres og sælges, og hvem, der producerer og sælger reguleres også gennem producenternes nationale oprindelse og gennem den pågældende nations $\varnothing$ konomiske og politiske (og, hvis det skal være, militære) magt. « ${ }^{39}$ En international arbejdsdeling efter komparative omkostningsfordele kan derfor også kun realiseres tilfældigt, nemlig når nationalstaternes »politiske indgreb « indebærer, at de relative omkostningsfordele forvandles til absolutte prisfordele ${ }^{40}$.

Ligeså korrekt det er i verdensmarkedsanalysen at gå ud fra en anden politik- $\varnothing$ konomi-relation end i unders $\varnothing$ gelsen af den kapitalistiske produktionsmådes almene struktur, ligeså forkert er det i verdensmarkedskonkurrencen kun at se en politisk kamp mellem nationale bourgeoisier om fordelingen af merproduktet. Tilla Siegel fors $\emptyset$ ger ingen steder i sin analyse, at foretage en differentieret undersøgelse af forholdet mellem de to instanser.

38. Siegel, op.cit., s. 84 .

39. Siegel, op.cit., s. 187.

40. Siegel, op.cit., s. 196. 
Betydningen af det kapitalistiske verdensmarkeds liberaliseringsfaser for den internationale kapitalkonkurrence, årsagerne til sådanne udviklingsfaser, virkningerne af, at nationalstaterne ikke politisk griber ind i de økonomiske forholds struktur, alt dette bliver ikke engang nævnt af Tilla Siegel. Den politiske instans' store indflydelse på den økonomiske kamp, som er Tilla Siegels udgangspunkt, hindrer hende i at få øje på disse problemstillinger, og hindrer dermed en differentieret analyse af verdensmarkedsprocessen.

\section{Nationalstaten som nationalkapital (SOST).}

SOST (Sozialistische Studiengruppen) giver en i sidste instans historisk forklaring på modsigelsen mellem kapitalens kosmopolitiske tendens på den ene side og eksistensen af nationalstater på den anden. I første omgang bliver det slået fast, at nationsbegrebet ikke kun har en politisk og kulturel betydning, men også en reel økonomisk: »Nations-begrebet betegner ikke kun en politisk, sproglig, kulturel enhed, men også en økonomisk helhed, og det er netop ud fra denne, at den relative politiske, kulturelle osv. homogenitet først reproducerer sig. Nationen eksisterer $\varnothing$ konomisk som nationalkapital hhv. nationalt lønarbejde, som er nationalkapitalens modpol. Kun på denne måde er det muligt at løse det teoretiske dilemma, at nationalstater skulle sønderrive, hvad økonomisk allerede tenderer i retning af en højere enhed. De mange enkeltkapitalers reelle sammenfatning er imidlertid nationalkapitalens reelle eksistens. «11

Kapitalens reelle eksistens som nationalkapital finder udtryk i enkeltkapitalernes orientering mod en national gennemsnitsprofitrate. De for kapitalbevægelsen afgørende momenter som gennemsnitlig arbejdsintensitet, arbejdsproduktivitet, pris på varen arbejdskraft og merværdirate er nationalt bestemte størrelser. Denne nationale strukturering af kapitalen skyldes historiske processer i overgangsfasen fra feudalisme til kapitalisme.

»I undersøgelsen af verdensmarkedsforholdene er det særlig vigtigt at begrunde, hvorfor den samfundsmæssige totalkapital i den realt eksisterende kapitalisme eksisterer i form af en flerhed af separate, nationale totalkapitaler. Denne begrundelse for de enkelte totalkapitalers antal og afgrænsning i forhold til hinanden viser hen til deres oprindelsesproces under før-kapitalistiske betingelser. Ligesom andre $\varnothing$ konomiske forhold bærer også kapitalens økonomiske formbestemthed sine historiske spor (jvf. MEW 23, s. 183f). Nationalkapitalerne har udviklet sig 
indenfor rammerne af historisk foreliggende naturlige og sociale betingelser og de heraf fremvoksende nationaliteter. Ved feudalismens afslutning kunne den kapitalistiske produktionsmåde, der, som Marx har sagt, endnu gik med krykker, kun indenfor bestemte arealer nivellere sådanne forefundne historiske betingelser, således at der alt efter styrken bag de sociale og naturlige historiske forskelle har udviklet sig nationer og nationalkapitalér, som i større eller mindre grad har afgrænset sig overfor hinanden. $\ll^{42}$

SOST beskriver derefter grundtrækkene i nationalkapitalernes historiske dannelsesproces, samarbejdet mellem det absolutte monarki og borgerskabet under merkantilismen samt det absolutte monarkis rolle $\mathrm{i}$ forbindelse med opdelingen i de forskellige koloniimperier og handelsområder. På denne måde konstituerede der sig ifølge SOST forskellige nationale totalkapitaler, som - efter først at være dannet - til stadighed har reproduceret deres nationale form. SOST kan ganske vist kun give en $»$ foreløbig redeg $\varnothing r e l s e ~ «{ }^{43}$ for denne reproduktionstendens. 1) Bestemte $\varnothing$ konomiske størrelser udviklede en ejendommelig form for national stabilitet, f.eks. kreditvæsenet og fagforeningerne. 2) I visse tilfælde sker der desuden en lovgivningsmæssig forandring af nationens $\varnothing$ konomiske stabilitet. 3) En international udjævning af én økonomisk størrelse, f.eks. lønnen, er ikke mulig. De forskellige $\varnothing$ konomiske størrelsers vekselvirkning, som er nationalt bestemt, vanskeliggør internationale udligningsprocesser. Det er ukorrekt kun at opfatte den internationale konkurrence som en tendens, der overvinder alle vanskeligheder og fører til udligning mellem nationerne. Høj eller lav gennemsnitsproduktivitet, høje eller lave lønomkostninger, fleksibelt eller stift kreditsystem osv., alt dette er våben, som kan afgøre spørgsmålet om sejr eller nederlag i den internationale konkurrence, altså våben, som - og dette er det afg $\varnothing$ rende - $\mathrm{g} \emptyset \mathrm{r}$ det muligt for én nation at forsvare sin velstand på bekostning af andre nationer. Nationale forskelle i den industrielle udviklingsgrad er altså ikke blot udgangspunkt for en nivellering; de er også det grundlag, hvorpå der sker en yderligere udvidelse af de økonomiske »kløfter « mellem visse lande. Den internationale handel og kapitalbevægelserne udgør et modsigelsesfyldt forhold af nationernes indbyrdes tiltrækning og frastødning. Nationalkapitalistiske forskelle er derfor såvel forudsætning for som et bestandigt produceret resultat af sådanne internationale $\varnothing$ konomiske kampe. $\ll^{44}$

42. SOST, op.cit., s. 18.

43. SOST, op.cit., s. 29.

44. SOST, op.cit., s. 30. 
Man kan rejse følgende indvendinger mod SOST's »udledning « af forholdet mellem politik og økonomi på verdensmarkedet:

1) SOST beskriver kun, men forklarer ikke, forholdet mellem det absolutte monarki og bourgeoisiet. Hvorfor var det f.eks. »feudalstatens funktion at frembringe den kapitalistiske produktionsmådes rammebetingelser og dermed jævne vejen for den fremadstræbende borgerklasse $\ll 4$.

2) Der er tale om en kortslutning, når handelskrigene og den monopolistiske optræden $\mathrm{i}$ forbindelse med absolutismen forklares med, at den økonomiske underudvikling ikke har muliggjort en åben konkurrence ${ }^{46}$. Den merkantilistiske $\emptyset$ konomiske politik skyldes snarere den særlige sammensmeltning af instanserne politik og økonomi som kendetegner den feudale produktionsmåde. Selvfølgelig havde det også under den oprindelige akkumulation været muligt med en åben konkurrence mellem de forskellige dele af Europa og verden, og desuden var de internationale produktivkraft-forskelle indenfor landbruget og næringslivet mindre i denne periode end efter den borgerlige revolution.

3) Med overgangen fra det absolutte monarki til det borgerlige demokrati sker der ikke uden videre, som SOST hævder, en »normalisering« af forholdet mellem basis og overbygning ${ }^{47}$. Ganske vist omformes forholdet mellem politik og økonomi internt i den kapitalistiske produktionsmåde afgørende i forhold til den feudale, men i de eksterne relationer bibeholdes sammensmeltningen af de to instanser. Netop dette forhold kræver en forklaring, og SOST bliver os her svar skyldig.

4) Henvisningen til de momenter, som bestandig reproducerer totalkapitalens reelle nationale eksistens, er cirkulær, idet reproduktionen af den nationale eksistensform allerede forudsætter det, der skal forklares, nemlig nationalstaten. Svaret skal snarere søges i nationalstatens beskyttelses- og udligningsfunktion i forhold til de svagere udviklede nationale kapitaler, en nationalstatsfunktion, som SOST benægter.

SOST's undersøgelse indtager således en position, som er helt modsat Tilla Siegels »politik-fikserede « analyse. Ganske vist tager SOST udgangspunkt i en national- $\not$ konomisk strukturering af verdensmarkedet, men uden at beskæftige sig med den internationale konkurrences national-statslige processer. SOST's teser er dermed økonomistisk forkortede.

45. SOST, op.cit., s. 22.

46. SOST, op.cit., s. 23.

47. SOST, op.cit., s. 24. 


\section{Nationalstaten som formidlingsinstans for nationale totalkapitalers økonomiske ekspansionsinteresser og politiske handlingsstrategier (A. Statz).}

I sin analyse fors $\emptyset$ ger A. Statz ${ }^{48}$ at udvikle de særlige formidlingsrelationer, som eksisterer mellem politik og økonomi på det kapitalistiske verdensmarked. Det drejer sig om »at bestemme nationen som en enhed af $\phi$ konomi og politik på verdensmarkedet og national-statsligheden som en forudsatning for kapitalens verdensmarkedsbevagelse ${ }^{49}{ }^{49}$ Af Statz' redundante og kinesiske-æske-argumentation kan man udfiltrere følgende tre problemstillinger som de væsentligste for udviklingen af hans centrale tese $\mathrm{e}^{50}$ :

- forholdet mellem logik og historie ved den kapitalistiske produktionsmådes gennemsættelse,

- bestemmelsen af forholdet mellem »kapital i almenhed « og kapitalens reelle eksistens som national totalkapital,

- handlings- og interessestrukturernes betydning for verdensmarkedsanalysen.

Forskellen mellem Statz' undersøgelse og de andre teorier, vi har diskuteret, fremgår klart af følgende programmatiske formulering: »... således må ... nationalstaten som politisk magt, som politisk overbygning, udledes af verdensmarkedets $\varnothing$ konomiske struktur ${ }^{51}$. Fors $\emptyset$ get på at udlede nationalstaten af verdensmarkedets $\varnothing$ konomiske struktur forudsætter imidlertid en særlig forståelse af den kapitalistiske produktionsmådes logik og historie. »Dette forhold mellem forudsætning og resultat er, som diskussionen om verdensmarkedet som den kapitalistiske produktionsmådes forudsatning og resultat har vist, ikke kun et logisk forhold i den begrebslige udledning. Det har sit reale grundlag i vareproduktionens udvikling og fulde udfoldelse som kapitalistisk vareproduktion. For at begrunde verdensmarkedets nationale struktur er det nødvendigt i detaljer at udfolde dette forhold mellem en kategorial bestemmelse og dens reale grundlag.

Den styrende problemstilling er her, hvorvidt og hvorfor det særlige forhold mellem politik og økonomi ikke blot fremstår som en forudsætning for kapitalens værdiøgning på verdensmarkedet, men også nødvendigvis produceres og reproduceres af kapitalen selv $\ll^{52}$.

48. A. Statz: Grundelemente einer politökonomischen Theorie der westeuropäischen Integration - Das Verhältnis von Ökonomie und Politik im internationalen Kapitalismus und der widersprüchliche Charakter der EG, Frankfurt/M. 1979.

49. Statz, op.cit., s. 7.

50. Vi skal ikke her give en fremstilling af Statz' teser om Fællesmarkedet.

51. Statz, op.cit., s. 80.

52. Statz, op.cit., s. 88 
Statz viser derefter i en kort historisk skitse, hvorledes den kapitalistiske produktionsmåde sætter sig igennem på »begrænsede territoriale områder ${ }^{43}$, hvorledes den tilegner sig den førkapitalistiske centralmagt og modificerer denne i overensstemmelse med sine love. I tilknytning til formuleringer i »Grundrisse « og »Kapitalen ${ }^{54}$, hvor Marx bemærker, at bestemte historiske forudsœetninger for kapitalen (f.eks. de umiddelbare producenters adskillelse fra deres produktionsmidler) efter den kapitalistiske produktionsmådes gennemsættelse fremstår som resultater af dens væren som kapital, slutter Statz analogt til forholdet mellem verdensmarked og nationalstat: »Den særlige verdensmarkedsstruktur, som udspringer af overgangen fra én samfundsformation til en anden, fremtræder nu som forudsætning for kapitalens almene lovmæssigheder: Den nationale opsplittelse indgår i selv kritikken af den politiske $\varnothing$ konomis system $\ll^{55}$.

Med denne »metodiske« argumentation viser Statz helt klart, hvilke inkonsistenser, der kan snige sig ind i analysen, hvis man sammenblander logik og historie, erkendelsesobjekt og realobjekt ${ }^{56}$. Statz sammenblander her sin undersøgelses logiske og historiske problemstilling, idet han inddrager et bestemt historisk resultat (her: den borgerlige revolutions anknytning til absolutismens nationale territorialstruktur) i den begrebslige udledning (her: nationalstaten som forudsætning for den kapitalistiske produktionsmådes almene lovmæssigheder). Marx gør det ganske vist klart, at bestemte historiske forudsætninger med den kapitalistiske produktionsmådes udvikling kommer til at fremstå som produkter af den udfoldede kapitalistiske produktionsmåde (f.eks. den dobbelt frie lønarbejder). Albert Statz' analyse af forudsætning og resultat må imidlertid slå fejl, fordi nationalstaten netop ikke kan udledes begrebsligt af kapitallovene og derfor ikke er deres resultat. Den kapitalistiske produktionsmådes logik og historie skilles her for at gå hver sin vej. Interessant nok undlader Statz i unders $\varnothing$ gelsen af verdensmarkedets $\varnothing$ konomiske struktur at give en detaljeret fremstilling af den internationale kapitalkonkurrences lovmæssigheder. I stedet henviser han til Kohlmey ${ }^{57}$, som imidlertid i sine arbejder mangler nationalstatsanalysen. Statz har ikke kunnet leve op til sin programmatik, at udlede nationalstaten af verdensmarkedets $\varnothing$ konomiske struktur.

53. Statz, op.cit., s. 88 .

54. Statz, op.cit., s. $94 \mathrm{ff}$.

55. Statz, op.cit., s. 99.

56. L. Althusser: Das Kapital Lesen, Bd. i, s. 59ff.

57. Statz, op.cit., s. 311, note 78. 
Heller ikke hans analyse af forholdet mellem real totalkapital og »kapital i almenhed « bidrager det mindste til opklaring af spørgsmålet om forholdet mellem politik og økonomi på verdensmarkedet. Statz undersøger planskitserne til den marxske hovedværk samt verdensmarkedsudledningens »placering « i Grundrisse og Kapitalen. Han kommer til det resultat, at Marx ville have analyseret staten og verdensmarkedet i en eventuel fortsættelse af sit værk. På grundlag af talrige henvisninger, som Marx gør i Kapitalens 3. bind, antager Statz videre, at den »nationale totalkapital «skal betragtes som den reale eksistens af »kapital $\mathrm{i}$ almenhed «. Heraf drager han følgende slutning: »På dette sted er det nu muligt at bestemme grunden til, at Marx' henvisninger til verdensmarkedet og de forskellige polit $\varnothing$ konomiske grundbestemmelser får en $n \phi d v e n d i g$ karakter på bestemte »steder « i fremstillingen af Kapitalen. Da man ikke for verdensmarkedssammenhængen kan forudsætte en fælles sammenhængende cirkulation som real totalitet, bliver det $\mathrm{i}$ to henseender nødvendigt at foretage modifikationer i den almene begrebslige bestemmelse. På den ene side må de udfoldede kategoriers begrænsning til den nationale totalkapital indgå i analysen ..., på den anden side kan de særlige relationer mellem de nationale totalkapitaler ikke inddrages i de almene bestemmelser, men må tilføjes som supplerende og oplysende $»$ modifikationer $\ll^{58}$.

Alene af den grund, at Marx selv har sagt meget lidt om disse modificerende relationer, vil det være nødvendigt med en analyse af »verdensmarkedets politøkonomiske kerneform«. Dette er imidlertid ikke hovedformålet med hans arbejde og vil derfor ikke blive videreudviklet her. I stedet for at udforske verdensmarkedets kernestruktur, hvorud fra han egentlig som bekendt ville udlede nationalstaten, fremlægger Statz altså nogle formodninger om planskitserne for det marxske hovedværk og om begrebet »kapital i almenhed « som relaabstraktion. Dette er en mangel, i betragtning af, at »Marx' hyppige revideringer af planskitserne, selve hans hovedværks uafsluttede karakter samt den inkonsistens, der præger hans få randbemærkninger om verdensmarkedet, betyder, at erkendelsesværdien af det marxske værk for en verdensmarkedsanalyse er yderst beskeden.

Den egentlige betydning af Statz' arbejde ligger i udviklingen af den tredie argumentationsstreng, som har at gøre med formidlingen mellem politiske handlingsstrukturer og den økonomiske verdensmarkedsanalyse. Statz anklager den hidtidige verdensmarkedsteori for i vidt omfang at have overset betydningen af politiske handlings- og interessestrukturer for

58. Statz, op.cit., s. 148. 
verdensmarkedsanalysen. Statz formulerer problemet som følger: »De $\emptyset$ konomiske formbestemmelser, som fremstår ved afslutningen af analysen af den politøkonomiske kerneform, viser samtidig ud over sig selv: Klassernes interesse- og handlingsstrategier, som fremstår ved afslutningen af kritikken af den politiske økonomis system, og gennem hvilke de nationale reproduktionsprocesser optræder udadtil som økonomiske og politiske enheder på den nationale totalkapitals og de politiske, statsligt formidlede formers niveau, må inddrages i analysen i deres særlige struktur og indbyrdes relationer ${ }^{59}$. Idet nationalstaten udadtil sammenfatter samfundets $\varnothing$ konomiske $o g$ politiske interesser, som i en handlingsstrategi sættes i relation til det internationale system, sker der en forskydning af basis-overbygnings-problematikken. Disse sammenhænge kan i sidste instans føres tilbage til en »dobbelt formbestemmelse af verdensmarkedet $«$ : »Formen for enkeltkapitalernes relationer som bestanddele af nationale totalkapitaler og de deraf følgende modifikationer af de politøkonomiske lovmæssigheder; og den særlige karakter af forholdet mellem politik og $\emptyset$ konomi og den kapitalistiske produktionsmådes globale sammenfatningsproces, hvori lovmæssighederne for de enkelte nationale totalsamfundsmæssige totaliteter indgår $\ll^{60}$.

Det er ganske vist fortjenstfuldt, at denne problemstilling fremhæves og pointeres; imidlertid indløser Statz ikke sin egen målsætning. Faktisk kommer forfatteren ikke længere end til permanent at reformulere problemstillingen gennem hele sit arbejde. Denne mangel må føres tilbage til den første mangel i Statz' analyse: Idet han undlader at udvikle verdensmarkedets politøkonomiske kerneform og derfor ikke begrunder sin tese om muligheden af at udlede nationalstaten af økonomien, mangler han også et grundlag for sin argumentation angående den politiske instans' større autonomi i verdensmarkedsanalysen. Først undersøgelsen af de politøkonomiske strukturer kan systematisk besvare spørgsmålet om den politiske instans' særlige handlingsautonomi på verdensmarkedet, dens tilbagetræknings- og interventionsstrategier.

Oversat af Mogens Andersen

59. Statz, op.cit., s. 150.

60. Statz, op.cit., s. 169. 


\section{Weber eller Marx}

\section{- Om konstellationen mellem idealtyperne i protestantismetesen*}

Jürgen Ritsert

Hvor ofte har man ikke set Max Webers 'protestantismetese' spillet ud mod Marx? Hvor stærkt vokser ikke bunken af de hver gang endegyldige beviser fra forskellige marxister for, at Weber skulle være en slem »idealist « eller »bourgois «? Er den, som er ude efter den sande forskel i de to teoriers kerne og praktiske implikationer virkelig tjent med citater, hvoraf det skal fremgå, at kritikken af den politiske økonomi for længst en gang for alle har indset alt, også 'protestantismetesen'? »Kulten omkring pengene har sin askese, sin forsagelse, sin selvopofrelse - sparsommeligheden og beskedenheden, foragtelsen af de verdslige, temporære og forgængelige nydelser; jagten efter den evige skat. Deraf sammenhængen mellem den engelske puritanisme eller også den hollandske protestantisme med pengemageriet «. Marx, Grundrids, Kurasje/Modtryk 1974 s. 133). Lad os overlade disse pligtøvelser til dem, som opfatter dem som nyttige.

Jeg vil i første omgang blot gå ud fra en yderst simpel formodning: Weber og Marx forfølger - på hver sin forskellige måde - begge en række problemer, som hos begge to og deres tilhængere til dels fortsat består som problemer. Det forekommer mig, at det er problemstillinger af en sådan art, som ofte får etiketten 'struktur og subjekt'. Jeg vil med dette relationsproblem for $\varnothing j$ je unders $\emptyset \mathrm{ge}$ en anden formodning lidt nærmere: I sin berømte studie »Den protestantiske etik og kapitalismens ånd $\ll^{1}$ bearbejder Weber dette problem på en sådan måde, at han ikke blot som en mulighed, men meget ofte også i forhold til det han faktisk udtaler sig

\footnotetext{
* Artiklen er opstået som et led i et større arbejde med socialvidenskabernes socialhistorie, hvor bl.a. diskussionen af forholdet mellem Marx og Weber indgår. En uddybet metodologisk argumentation omkring de problemer, der rejses i forbindelse med den her offentliggjorte artikel om Den Protestantiske Etik findes i Ritsert, Sozialgesichte der Soziologie, Bericht: SoSo 1 Frankfurt/M Okt. 1980. 10. Den her bragte artikel om den protestantiske etik og idealtyperne er ikke offentliggjort før. 1. Jeg citerer efter flg. udgave: Max Weber, Gesammelte Aufsätze zur Religionssoziologie, Tübingen 1974. Som forkortelse for artiklen »Den protestantiske Ethik.... bruges PE. (Tallet efter skråstregen ved sideangivelser henviser til den danske oversættelse »Den protestantiske etik og kapitalismens ånd fra 1972. Denne udgave er udsolgt men findes i genoptryk udgivet af Gyldendals studiefakler 1981, 2. oplag Oslo. o.a.)
} 
om, beskæftiger sig med (må beskæftige sig med?) centrale motiver i den marxistiske teori. At registrere og rekonstruere dette kunne - omvendt måske også være en hjælp til den så ofte postulerede 'materialistiske teori om subjektet'.

Kapitalismens ånd fremstår hos Weber som historisk individ. Lige som f.eks. 'Bismarks politik' eller 'den middelalderlige kristendom' materialiserer den sig derfor som det til enhver tid konkrete resultat af en kulturvidenskabelig fremgangsmåde, som er kendetegnende for Weber, nemlig idealtypedannelsen. Den følger altså som resultat af et »til værdier relateret« udvalg af sagsforhold i kulturvirkeligheden (»abstraktioner«), af udvalgte kendetegn, som er taget ud af deres sammenhæng og tilspidset for nogens vedkommende til tankemæssige grænsetilfælde (»pointeringer«), og sluttelig af indarbejdelsen af sådanne aspekter i tankebilledet, som slet intet modsvarer i virkeligheden (»idealisering «). I og med at det i forbindelse med kapitalismens ånd handler om et historisk individ, altså om »et kompleks af sammenhænge i den historiske virkelighed, som vi sammenfatter til et hele set ud fra deres kulturbetydning. "(PE 30/25), bliver vi på forhånd konfronteret med vanskelighederne $\mathrm{i}$ begreberne »kulturbetydning « og »værdirelatering« hos Weber. Selv det harmløse ord »vi« indeholder et problem. ${ }^{2}$

Et sted skriver Weber, at fænomener i den sociale virkelighed »tildeles « kulturbetydning »af os«. For forenklingens skyld bør »tildeling af kulturbetydning « måske splittes op i enkeltheder: Der eksisterer en proces, efter hvilken a) subjekter (»vi«), som anerkender b) bestemte »værdier« som forpligtende, c) på grund af netop denne orientering mod værdier kun skænker bestemte genstande og kendetegn tankemæssig opmærksomhed og hensyn i

2. Se omkring dette problem mere udførligt: J. Ritsert, »Wertbeziehung« to the societal basis - Two lines of argument in Marx Webers theory of action? in: L. Nowak (ed) Social Classes, Action and Historical materialism, Amsterdam 1982.

Fra denne artikel har Kurasje klippet følgende:

»Hele processen, hvor vidensobjektet konstitueres eller videnskabelig indsigt i virkeligheden opnås under styring af værdier, blev af Weber kaldet »værdirelatering « (Wertbeziehung). At sætte aspekter af det virkelige i relation til værdier, giver betydning til virkeligheden, elementer af virkeligheden får »kulturbetydning « (Kulturbedeutung) eller kulturel betydning.« For os er den empiriske virkelighed 'kultur' fordi og for så vidt vi sætter den i forbindelse med værdier; den opfatter de og kun de dele af virkeligheden, som betydningsfuld for os som følge af denne forbindelse.« ... At relatere aspekter af virkeligheden til værdier betyder at give kulturel betydning (kulturbetydning) til disse elementer eller lag. Med andre ord: ledet af værdier udvælger vi specielle punkter af den uendelige mangfoldighed af historiske karakteristika og relationer, og sammensætter eller komponerer dem succesivt til et »historisk individ « - det vil sige: et »kompleks af forbindelser i den historiske virkelighed som vi begrebsmæssigt forener til et hele under synsvinklen, deres kulturelle perspektiv.« 
adfærden. For så vidt denne selektivitet d) bliver styret af orienteringen mod samfundsmæssigt (kulturelt) alment gældende værdier (»Kulturværdier«) er noget »kulturbetydningsfuldt « for den. ${ }^{3}$

Når kulturværdiideerne c) leder frem til den værdirelaterede konstitution af erfaringsobjekter ud af »begivenhedernes kaotiske mangfoldighed « og vejleder forskernes og forskersamfundets idealtypedannelse, har disse ideer funktion af »erkendelsesinteresse«. Disse »værdiideer« gælder ikke bare som målestok for vurderinger, men de omfatter også normer, handlingsregler, planer, mål, hensigter, mønstre for vurdering af situationer (f.eks. verdensbilleder). Og den »empiriske virkelighed bliver 'kultur' for os, fordi og for så vidt $v i$ sætter den i relation til værdiideer... « ${ }^{4}$. Men hvem er »vi«, som vi yder denne ejendommelige præstation for? For det første sikkert videnskabsmænd, som har dannet en indbyrdes sammenlignelig erkendelsesinteresse gennem orienteringen mod fælles »kulturværdier«. I lyset af deres erkendelsesinteresser hæver de alle sådanne genstande og kendetegn op fra den uendelige mangfoldighed af faktiske begivenheder, som så kan indgå som »momenter « $\mathrm{i}$ den ligeledes værdirelaterede »komposition « (Weber) af en idealtype. For det andet er der også tale om »vi« som hverdagsmennesker, hvis værdirelationer ligeledes hjælper med til at give betydning (for os) til bestanddele fra en kaotisk fremtrædelses- og begivenhedsrigdom. Anskuet således er det nok heller ikke noget tilfælde, når Weber taler om »de værdiideer, som behersker...forskerne og deres tid $\aleph^{5}$ Kulturvirkelighed kommer ikke mindst istand gennem værdirelatering blandt mennesker i hverdagsverdenen.

Efter min opfattelse må man tage denne dobbelttydighed i betragtning, når man spørger efter det stof, som typen »kapitalismens ånd «skal sammenføjes af. Den sammensættes af en mangfoldighed af handlings- og holdningsregler, værdimålestokke, moralske anbefalinger og forpligtelser, ideer, utopier, opfattelser, som i selve kulturvirkeligheden, dvs. hos »os « som hverdagsmennesker $\mathrm{i}$ et bestemt historisk tidsafsnit, er eller har været i omløb. For

3. Den empiriske virkelighed er »kultur« for os, når og for så vidt vi sætter den i relation til værdiideer, den omfatter sådanne bestanddele af virkeligheden, som gennem denne relationibliver betydningsfulde for os, og kun sådanne. En ubetydeligt del af den til en hver tid betragtede individuelle virkelighed, farves af vores interesser, som er betingede af sådanne værdiideer; kun denne lille del har betydning for os og det har den, fordi den henviser til betingelser, som er vigtige for os som følge af dens sammenknytning med værdiideer« M. Weber, Die »Objektivität« sozialwissenschaftlicher und sozialpolitischer Erkenntniss, in: Gesammelte Aufsätze zur Wissenschaftslehre, Tübingen 1943, p. 28.

4. Om det weberske virkelighedsbegrebs dobbeltkarakter se 'Wertbeziehung' to societal.... op.cit.

5. M. Weber Die »Objektivität« ... op.cit. p. 184. 
så vidt hører de til en kulturvirkelighed, som altid allerede er konstitueret gennem de handlende subjekter orienteringer. »Vi« som historiker eller socialvidenskabsmand står overfor den opgave at skabe en komposition af idealtyper af dette stof. $\mathrm{Da} » v \mathrm{v} \ll \mathrm{i}$ det weberske projekt er beskæftiget med aspekter og elementer i en økonomisk etos, den kapitalistiske, må egentlig alle de af hverdagsagenternes »ideer « komme i centrum for opmærksomheden, hvis meningsindhold udtrykker hhv. betyder noget fra produktionens, fordelingens og konsumtionens område, eller står i en empirisk relation til sagsforhold indenfor disse områder. Anskuet således skulle den weberske kulturvidenskab faktisk være beskæftiget med »det $\varnothing$ konomiske hverdagslivs maximer « (PE 163/96). Det historiske spring i den tid, hvor den vestlige kapitalisme opstår, tillader imidlertid ikke en sådan direkte tilgang. Weber vælger derfor som første takt i kompositionen af sin idealtype »kapitalismens ånd « et dokument om hvilket han antager, at det allerede indeholder den kapitalistiske $\varnothing$ konomiske tænkemåde i »omtrent klassisk renhed « (PE 31/26): Benjamin Franklins »Retningslinier for en ung handelsmand « fra 1748.

Franklins forsvarstale for selvkontrol, tids $\varnothing$ konomi, ærefrygt for pengenes produktivitet, sparsommelighed, mådeholdenhed, ordenssans, men først og fremmest for arbejdsflid, tilbyder mere end blot tommelfingerregler til imødegåelse af økonomiske vanskeligheder. Det der lå ham på sinde var et etos, ikke blot en livsteknik, en kapitalistisk tænkemåde og sindelag, ikke et regelsæt for forretningsfolk. Denne etos viser personens hele livsførelse vejen, og forsyndelser mod dens principper betyder pligtfors $\emptyset$ mmelse ikke blot uduelighed. Det ligger i hele det weberske projekts logik, at man skulle videreudbygge det hos Franklins nærmest idealtypisk foreliggende udtryk for kapitalistisk tænkemåde og sammenføje det til en virkelig ren type. En sådan er nødvendig for at kunne gennemtrænge og samtidig forstå mangfoldigheden i kulturvirkelighedens processer, skønt hverdagsmenneskene på deres side allerede - f.eks. når de vælger bestemte muligheder og udelukker andre - gennem »værdirelatering « har frembragt $\gg$ kulturbetydning «.

Men hos Weber hører det også til begrebet »kulturbetydning « at værdirelationer ikke blot leder enkelte få personers orientering, men først antager skikkelse af en betydningsfuld »anskuelsesmåde«, når de bliver båret af bredere menneskegrupper. Altså kunne en ren kapitalistisk tænkemådes idealtype også hjælpe til med at finde frem til hvorvidt denne ånd var fremherskende indenfor bestemte områder af kulturvirkeligheden, måske sågar indenfor bestemte klasser, grupper og sammenslutninger. Man kan følgelig tale om »fremhersken«, når der hos specifikke bærergrupper kan 
konstateres en tilnærmelse til det rene billede. På forskellige steder går argumenterne i denne retning. Således f.eks. når Weber til overvejelse anfører, at det på tærsklen til den ny tid på ingen måde var de »kapitalistiske foretagere blandt handelspatricierne, men derimod langt mere de opadstræbende grupper fra den håndværksmæssige middelstand, der (var) bærere af den tænkemåde, som vi her har betegnet som 'kapitalismens ånd'.« (PE 49/37). Alligevel er graden af den kapitalistiske etos' fremhersken ikke den for Weber afgørende problemstilling. I centrum for hans undersøgelse står som bekendt problemet om betingelserne for den kapitalistiske ånds tilblivelse. Men hvordan kom han frem til, at »denne tilblivelse er det som egentlig skal forklares « (PE 37/30); det er det den overvejende del af Webers udredning i virkeligheden koncentrerer sig om. Det er ikke hensigten med min fremstilling at følge udredningen i enkeltheder og endnu engang vurdere den. Jeg forholder mig kun til Webers forklaringsstrategi for så vidt den lader sig udbygge, eller helt igennem ombygge til en konstellation af idealtyper, som kan tjene til en mere tilspidset udgave af mine to udgangsspørgsmål:

1. Forbliver Weber med sin protestantismetese nødvendigvis en ren overbygningsteoretiker?

2. Hvor langt kommer han i den også for marxister problematiske bestemmelse af forholdet mellem socialstruktur og subjektivitet?

Weber spørger her - idet han tager et helt andet udgangspunkt end Marx - ikke først efter hvilke økonomiske interesser, kampe, magtudfoldelser, der ligger bag, hvad de klassiske nationaløkonomer har kaldt »den oprindelige akkumulation«. Det drejer sig for ham ikke om oprindelsen af kapitalistiske pengeophobninger, som kan værdiøges (jvf. PE 52 f/39), men om en etos, som udvikler sig, senere udbredes og når frem til at blive den fremherskende. Webers berømte svar på spørgsmålet om kapitalismens opståen koncentrerer sig om den protestantiske religion i almenhed, den asketiske protestantisme i særdeleshed. (jvf. PE 84 ff./57 ff). Hvorfor nu gå tilbage til religionen? Den tidlige kapitalisme opstår naturligvis i en tid, hvor religiøst indhold et langt stykke har et fast greb om en afgørende del af de personlige motiver, af verdens- og selvforståelsen hos de fleste mennesker.

Den kapitalistiske ånd kunne under de daværende betingelser naturligvis ikke bare træde frem i sækulære former. Når det samtidig ikke er muligt at gribe direkte fat i hverdagssproglige orienteringer, så byder til gengæld de skrevne moral- og trosartikler såvel som teologiske doktriner sig til som udgangspunkt. I disse måtte det kunne lade sig aflæse, hvilke af de tænkemåder, som var sammenhængende med økonomien, der 
dengang fik tildelt en religiøs præmie, og hvilke der ikke fik det. Og trosog kulturkampene drejede sig nu engang på det tidspunkt, dvs. i det 16. og 17. århundrede, i de »kapitalistisk mest fremskredne lande« (Nederlandene, England og delvis også Frankrig) om Calvinismen og dens varianter.

I følge Weber var det hos dens tilhængere, at kombinationen af en virtuos kapitalistisk forretningssans og »en fromhed, som gennemtrængte og regulerede hele livet «(PE 26/22) mest tydeligt kom frem. Dér blev på det mest eftertrykkelige udlovet frelse som præmie for en systematisk kontrolleret livsførelse og erhvervsmæssig foretagsomhed. I første omgang må det undre, fordi Calvin hældede til en streng skæbnetro (prædestinationslære), som koblede fordømmelse og frelse til Guds oprindelige afgørelse uden nogen chance for individuel indblanding. Men for de troende var det sjæleligt nærmest uudholdeligt, at de overhovedet ikke havde noget holdepunkt i det jordiske liv for, hvor de stod i forhold til nåden. I den teologiske opfattelse på daværende tidspunkt satte det sig da også mere og mere igennem, at skønt de jordiske handlinger ikke kunne være et virksomt middel til at nå den himmelske tilstand, så kunne de jordiske handlinger i det mindste være et tegn på udvalgtheden. (PE 110/69). Gud hjælper den, som hjælper sig selv, den som holder sig selv i tugt, den som skaber sig visheden om sin udvalgthed (PE 111/70). Den troende måtte altså blot bestræbe sig på at finde og genfinde holdepunkter for nådesvalget i sit virke. Er det daglige virke til Guds ære ikke nogen realgrund for nådestildelingen, så vinder det dog tiltagende tilforladelighed som erkendelsesgrundlag (PE 147/86). Således tilskyndet af de religiøse doktriner til bestandig at agte på sig selv og konsekvenserne af sine handlinger og dermed på betingelserne for sin frelse, forstærkes hos både enfoldige og mere sofistikerede troende motivet til selvkontrol, disciplin og travl foretagsomhed. Dette udfolder sig som personlige indstillinger, foretagsomheden bliver et kald, en personlig pligt. »Reformationens effekt som sådan var i første række kun - i kontrast til den katolske opfattelse - at den moralske accent og den religiøse præmiering for dennesidige, verdslige erhvervsmæssigt indrettede arbejde svulmede voldsomt op« (PE 74/48). Det daglige erhvervsarbejde blev, formidlet over den betydning religionen havde for den enkelte, så at sige indplantet i protestanternes og de reformertes tænkemåder og sindelag.

Naturligvis gjaldt arbejdet, virket, også allerede før reformationen som et afgørende middel til asketisk livsførelse. Arbejdet skulle beskytte mod udskejelser, forsømmelighed i luxus og moralsk forfald. Men efter Webers afgørende tese bliver arbejdet i og med den protestantiske etik til et mål i sig selv forankret i det enkelte subjekts motivstruktur. (PE 171/98), og 
dermed får den verdslige succes, i sidste ende det rastløst sammenbragte og sparsommeligt sikrede udbytte, en særlig hellighed. Det betyder altsammen imidlertid også en afgørende religiøs støtte til den enkelte, som i modsætning til, hvad der var tilfældet med den tidligere skatteophobningsimpuls, oplever pligtens etiske hellighed. Kort sagt: Protestantismen støtter den denne sidige askese og følgelig alle de tænkemåder, som giver den kapitalistiske ånd styrke til at sive ud og brede sig i hverdagslivet. »Den dennesidige protestantiske askese - således kan vi godt sammenfatte det hidtil sagte - virkede altså med fuld kraft mod den ugernerte nydelse af besiddelsen, den indsnævrede konsumtionen, især luxuskonsumtionen. Derimod befriede den i sin psykologiske effekt erhvervelsen af goder fra den traditionalistiske etiks hæmninger, den sprængte lænkerne, der var lagt på stræben efter gevinst, idet den ikke blot legaliserede, men (i den her fremstillede forstand) direkte anså denne stræben for at være villet af Gud« (PE 190/106).

Selv denne knappe skitse af den weberske argumentationsgang tydeliggør nogle problemer, som hidrører fra den indledningsvist beskrevne dobbelttydighed i hans lære om »kulturbetydning «: Også Weber kan naturligvis kun i meget ringe udstrækning forlade sig på materiale, som umiddelbart stammer fra hverdagsverdenen. Han komponerer ikke i nævneværdig grad sin idealtype 'den kapitalistiske ånd' på hverdagsorienteringerne hos grupper af bærere af sådanne forestillinger, men på teologiske skrifter fra Calvin, Luther, Baxter, Franklin og andre. Den tese som bestandig kommer til syne hos ham, at han hermed har fået fat om det afgørende i en ånd, som i det mindste var fremherskende blandt grupperinger i den sociale virkelighed, må bero på den overvejelse, at den protestantiske teologi har formuleret anskuelser, som »vi« som troende i den daværende periode mere eller mindre eftertrykkeligt har tilpasset os. Det er nok problemet for enhver undersøgelse, som retter sig ind mod historiske social-karakterer. Et specifikt problem opstår ganske vist af karakteren af og den metodiske stringens i de idealtyper, som Weber betjener sig af til udvikling af protestantismetesen. Er f.eks. »lutherdommen«, »calvinismen«, »metodismen« etc. enkelte idealtyper, som igen indgår som elementer i konstruktionen af den omfattende type »asketisk protestantisme «? Er den »asketiske protestantisme« et særligt historisk individ, den »kapitalistiske ånd « et andet, hvis opståen skal forklares ud fra det første? Jeg vil ikke gå ind på disse spørgsmål, men går ud fra den harmløse opfattelse, at den »asketiske protestantisme « hos Weber er en for-form eller tidlig form af den kapitalistiske ånd selv; på en måde dens kimcelle! Følgelig må det så være tilladt at begribe disse oprindelses- 
former for kapitalismens ånd som dén idealtype, som behersker Webers værk $^{6}$. For mig drejer det sig nemlig i det følgende om to andre typer, som hos Weber lever et gedulgt og alligevel mærkbart liv.

Forstår vi et »historisk individ « som resultatet af en idealtypiserende konstruktion, der tydes $i$ dens forhold til kulturvirkeligheden, så kan man begribe »den traditionalistiske etik « (PE 190/106) eller den »(katolske) traditionalisme « som modtypen til den asketiske protestantisme. Dette historiske individ omfatter karaktertræk fra den middelalderlig-katolske religiøsitet og dennes tilsvarende livsstil. Weber har ikke udarbejdet denne type på en lige så klar og detailleret måde som den »kapitalistiske ånd « $\mathrm{i}$ dennes tidlige form, men i teksten findes der hele tiden henvisninger til enkelte af dens bestanddele og disses forhold til de økonomiske handlingsmønstre. Hvis man komponerede de spredte henvisninger til traditionalismen idealtypisk sammen, ville der fremkomme et billede af førkapitalistiske livsanskuelser. Funktionen af en sådan konstruktion er klar: Den tjener Weber som en slags kontrastbaggrund, som negation eller modpol i forhold til afgørende aspekter af den kapitalistiske ånd, således at dennes historiske ejendommeligheder træder tydeligere frem. Det kanoniserede renteforbud til forskel fra den protestantisk præmierede fortjeneste-tænkemåde står som klassisk eksempel på sådanne modsætninger. Eksempler som dette hjælper til at afgrænse den ene betydningsfulde kulturfremtrædelse »i dens individuelle egenart« (PE 30/25) fra den anden. Til forskel f.eks. fra den strenghed i livsførelsen, som protestantismen forlanger af den enkelte, til forskel altså fra dennes »uendelig tyngende og alvorsprægede reglementering af hele livsførelsen, der gik så vidt som tænkes kunne inden for alle sfærer af det private og offentlige liv »(PE 20/18), forholder katolicismen sig strengt mod kætteren, men ikke mod synderen. Denne kan gøre bod, gøre afbigt eller frikøbe sig fra skærsilden (jvf. PE 59/43, 113/71). I den middelalderlige kultur, som beherskedes af den katolske etos, fandtes den bedriftsmæssigt rationelle organisation af det daglige liv ikke i nævneværdigt omfang. Virke fremtræder i et andet lys. Erhvervsbeskæftigelse er hverken en gudsbestemt pligt eller et kald til handlen, der forøgede indsatsen og fortjenesten. Således ansporede f.eks. merfortjenesten ikke arbejderen så meget som »det at arbejde mindre; han spurgte ikke: hvor meget kan jeg tjene om dagen, hvis jeg yder det mulige maksimum af arbejde, men hvor meget må jeg arbejde for at tjene det beløb, som jeg hidtil fik og som dækker mine traditionelle

6. Også selv om det måtte være svært at påvise, at denne ene idealtype er produktet af en strikt anvendelse af Webers metodologi. 
behov? «(PE 44/33). Sombart og andre konfronterer derfor det middelalderlige princip om dækningen af et ordnet behov, »næringen «, med det kapitalistiske princip om den rationelt organiserede fortjenestesøgning. For det middelalderlige menneske, der følger den katolske traditionalismes maximer, måtte det faktisk forekomme som en vej til fordømmelse at indrette sit liv på puklen og skraben-til-sig for »engang at synke i graven belastet med en stor materiel vægt af penge og goder « (PE 55/44). Det er altså ikke blot en teologisk strid, men en forandring af dybtsiddende tænkemåder, der står bag vendingen mod traditionalismen. Diskussionerne førte i en retning, hvor det lykkedes brede befolkningsgrupper »at omforme arbejdsopfattelsen til en følelse af erhvervspligt, arbejdet til et mål i sig selv«. Havde middelalderen endnu opfattet almisserne som en pligt, tiggerne ofte som en særlig stand (PE 199/110), så tvinger de tidlige kapitalister rodløse, fordrevne, tiggere og vagabonder ind i fattig- og arbejdshusene, i sidste ende ind i fabrikkerne.

Også askesens art er grundforskellig. Det denne-sidige i protestantismen står overfor det hinsidige i traditionalismen. Middelalderens munk var jo også på sin måde indstillet mod en metodisk livsførelse; bederitualernes tidstakt pålagde også hans dagsforløb en disciplin. Desuden har klostrene allerede længe før protestanterne dyrket arbejde som et middel til askese. »Det afgørende var imidlertid: at det i religiøs henseende metodisk levende menneske par excellence netop alene var og blev munken, at altså askesen jo mere intensivt den greb den enkelte desto mere trængte ham $u d$ af hverdagslivet, fordi det specifikt hellige netop lå i overbydelsen af den verdslige sædelighed«(PE 119/73). Denne forskel mellem den verdslige, i den borgerlige hverdag praktiserede askese og den munkelige asketisme, hvor munken - i det mindste i den idealtypiske rekonstruktion af munkens livsregler - trækker sig ud af dagsværket og erhvervsarbejdet, udgør en af de modsætninger, som Weber søger at afdække i konfrontationen mellem »kapitalistisk ånd « og »traditionalistisk etos«. Kort sagt: Weber arbejder i første omgang med to overbygningstyper, med to typiseringer af historisk kulturbetydende etikker. Den hovedrelation, som han afdækker mellem dem, er den delvis til modsætning tilspidsede forskel. Samtidig sætter han de to typer $\mathrm{i}$ et forhold af historisk følgen efter hinanden, også selvom begge tænkemåder eksisterer videre ved siden af hinanden og overlejrer hinanden i den kapitalistiske nyere tid. Weber insisterer imidlertid på den sluttelige gennemsatning (»fremhersken«) af den kapitalistiske ånd overfor den katolske traditionalisme.

De to overbygningstyper skal ikke - trods en nærliggende fordom herom forstås som statiske typiseringer i betydningen indoptagelse af historiske 
momenter. De indeholder hele tiden antagelser omkring betingelserne for deres forandring og udvikling. Således bliver der f.eks. omkring typen »kapitalismens ånd « på forskellige steder henvist til ændringer i bærergruppens motivationsbasis som grund til afslibningen af Calvins strenge prædestinationslære. Calvinisternes ganske menneskelige behov for i det mindste at finde anknytningspunkter for hvor de stod i forhold til nåden, kunne religionen ikke modstå i længden. Det gav på sin side indvirken på de kaldsforestillinger, som er kendetegnende for den kapitalistiske ånd. Webers idealtyper er altså på ingen måde blottet for en indre historicitet.

Alligevel tror jeg ikke, at det er tilstrækkeligt, at hænge den weberske protestantismetese op alene på konstellationen af disse to overbygningstyper eller deres underopdelinger. I det mindste må en tredie stor type drages frem som gedulgt argumentationsgrundlag. Denne resulterer imidlertid ikke som en komposition af elementer fra aktørernes betydnings- og situationsforståelse (hhv. fra teologiske indikatorer) i en etos, en ånd, men fører til et udtryk for socialstrukturelle kendsgerninger i kapitalismen, som ikke kan føres tilbage til betydningsindhold. M.a.o.: Det ville være en fejl, omend nærliggende, at antage, at Weber alene skulle udvikle sine overvejelser om kapitalismens opståen i forhold til træk fra en bestemt $\emptyset$ konomisk tænkemåde. Hans begreb om »kapitalismen « indeholder videregående konnotationer. Den skal hos ham forstås som et historisk individ, der ikke kun er konstitueret over den specifikke mening (Sinn), som et betydeligt antal menneskers handlinger måtte være orienteret efter. Hvis man ikke - som det sker hos mange systemteoretikere - på tautologisk vis sætter »mening « lig med selve det, at noget er organiseret eller lig med organiserende processer i sociale systemer i det hele taget, så tager også Weber implicit hensyn til kapitalismens side af faktisk (materiel), socialstrukturel sammenfatning, og selvom denne strukturtype også kun optræder sporadisk i teksten, så fremgår dens elementer tydeligt nok i forbemærkningen til bogen (PE 1-16/3-13): Kapitalismen skal forstås som et særligt system, der kendetegner en bestemt epoke af den vestlige udvikling. Uden tvivl er den også lige så afhængig af en specifik etos', en specifik ånds, gennemsætning som af grundfæstningen af helt bestemte motiver hos dens agenter, f.eks. den stadige stræben efter ny gevinst, stadig voksende rentabilitet og beredskab til konkurrenceadfærd (PE 4/5-6).

Men denne samfundsmæssige helhed udgør en sammenhæng, hvis ordningsprincipper også sagtens kan influere på de enkelte subjekters aktivitet samt selv- og verdensforståelse. »Indenfor en kapitalistisk ordning af den samlede $\varnothing$ konomi ville en kapitalistisk enkeltvirksomhed, som ikke orienterer sig mod chancen for rentabilitetsopnåelse, være dømt til 
undergang « (PE 4/6). Der findes lovlignende sammenhænge mellem strukturbetydningsfulde enkeltforhold og -foreteelser. »Lovlignende« skal her ikke forstås via det nomologiske lovbegreb, men betyder begivenhedsfølger, som gentager sig i et tidsafsnit, - kapitalistisk reproduktion. »Strukturbetydningsfuld « kan forstås som pendent til »kulturbetydningsfuld « og skal således udtrykke en enkeltheds funktion og rolle i reproduktionskredsløbet: Der rejser sig dermed det spørgsmål, hvilke aspekter af den mangfoldige kapitalistiske virkelighed der må fremhæves, hvilke abstraktioner, pointeringer og idealiseringer der må foretages for at finde et idealtypisk udtryk for lovmæssighed(er) og strukturbetydningsfulde fænomener i kapitalismen som system. Webers bestemmelsesfors $\varnothing \mathrm{g}$ kommer i dette tilfælde forbavsende tæt på Marx'; thi også for Weber har den »rationel-kapitalistiske organisation af (formelt) frit arbejde « (PE 7/8) kernestrukturel betydning i det historiske system »kapitalisme«. Vi ser et $\emptyset$ jeblik bort fra princippet om det rationelle, som utvivlsomt spiller en for Weber lige så karakteristisk som afgørende rolle i forsøget på at afgrænse den vesterlandske, »intet andetsteds udviklede form for kapitalisme « (sammesteds). Med samme eftertryk henviser han nemlig til det »formelt frie arbejde«s strukturbetydning. Formelt fri er lønarbejdet i forholdet til kapitalen. Kort sagt: I alle andre sociale systemer, som nok kender til stræben efter fortjenester, guld- og pengebegær, udbytning af arbejde, ekspanderende spekulations-, handels og finansinteresser, »mangler den moderne modsætning: storindustrielle driftsherrer og frie lønarbejdere« (PE 9). Også »adskillelsen af husholdning og virksomhed «, som hele tiden fremhæves af Weber og de fleste moderne lærebøger i økonomi, er heller ikke andet end et udtryk for dét kapitalistiske arrangement på den ene side at overlade den »frie « vare arbejdskraft til virksomhedsejerens og -lederens kommando i produktionen, mens »husholdningen « på den anden side skal udgøre stedet for de afhængiges og de selvstændiges forbrug af penge og goder. Betragtet efter dens strukturelt organiserende principper, som strukturtype, er den moderne kapitalisme også hos Weber ikke meget andet end »borgerlig virksomhedskapitalisme med dens rationelle organisation af det friearbejde« (PE 10/10). Et andet sted (PE 9/10) sættes kalkulerbarheden sågar efter arbejdskraftens bliven-til-vare. En eksakt virksomhedskalkulation, hedder det, er overhovedet kun mulig på grundlag af frit arbejde.

En drejning af den weberske argumentation, der retter sig imod Marx, når imidlertid også hermed sin yderste grænse. Thi den sædvanlige weberske relatering til kulturværdier blandes hele tiden sammen med konstitutionen af en ren strukturtype. I tilfældet med den tredie idealtype kommer denne 
relatering til syne i inddragelsen af værdiideen om målrationaliteten, som er afgørende for både Webers teoridannelse generelt og også for hans opfattelse af konstitution og udvikling af den vesterlandske kulturvirkelighed. Her hedder det f.eks. at man må regne sådanne forhold for førkapitalistiske, i hvilke »den rationelle virksomhedsmæssige kapitalvalorisering og den rationelle kapitalistiske arbejdsorganisation endnu ikke er blevet herskende magter for orienteringen af den økonomiske handlen« (PE 43/32). »Rationalitet « betyder i sådanne sammenhænge frem for alt beregnelighed af følger ved indsatsen af bestemte midler for mål, her: virksomhedsmål. »Rationel« var dermed virksomhedskalkulationen, bogføringen, gevinst- og tabsberegningen og andre symptomer på kapitalistisk regnskabsmæssighed (jvf. PE 4f, PE 61/5f, 44).

De aspekter af en strukturtype »kapitalisme«, som jeg har trukket frem, lader sig ikke simpelt underordne som et forbigående motiv i en fremstilling af den opkommende borgerlige ordning, der ubetvivleligt er koncentreret omkring den protestantiske etos. Thi Weber vil med sin undersøgelse vise, »om og hvorvidt religiøse indflydelser har været medvirkende $\mathrm{i}$ den kvalitative prægning og den kvantitative ekspansion af denne ånd ud over verden og hvilke konkrete sider af den på kapitalistisk basis beroende kultur, der kan føres tilbage til dem« (PE 83/54). Helt uden for enhver tvivl lader Weber her kultur bero på en kapitalistisk basis, og hvad skulle der være ment med denne basis andet end bestemmelser, som udgør strukturtypen? Hvad angår mit første spørgsmål om fikseringen af den weberske tænkning på ideer og tænkemåder, må der altså i besvarelsen være plads for differentieringen. Ingen vil med alvor påstå, at Weber havde til hensigt at sprænge rammerne af sin egen metologi. Denne styrer ham uden tvivl ind mod kulturværdi-ideer såvel i antagelserne om konstitutionen af hverdagsverdenen som også i idealtypedannelsen. Men protestantismetesen arbejder ikke kun med to store overbygningstyper (I: katolsk traditionalisme; II: kapitalistisk ånd), den arbejder også med en yderligere strukturtype, som først fylder begrebet om »kapitalismen« ud. Og videre: Bestemmelsen af forholdet mellem de tre typer forekommer mig at vejlede den egentlige konceptualisering af den borgerlige udviklingsproces hos Weber - hvordan så end accenterne også måtte ligge. Strukturen af denne konceptualisering skal kort sammenfattes:

Weber sætter »traditionalisme « og »kapitalistisk ånd « i tre grundrelationer til hinanden: 1) Forholdet mellem delvist til modsætning tilspidsede forskelle; 2) Relationen mellem typerne som en historisk følge af type II efter type I; 3) Voksende empirisk gennemsætning af den anden type overfor 
den første (»fremhersken«). Samtidig må der imidlertid også tages hensyn til arten af deres relateringer til strukturtypen:

1) »Adækvans « betegner hos Weber den grundrelation, hvori den protestantiske etik som den kapitalistiske ånds tidlige form skal stå i forhold til den »kapitalistiske basis « (jvf. ovenfor). Thi en økonomis »kapitalistiske form « og den ånd, hvori denne økonomi føres, står ganske vist generelt $i$ et forhold af 'adækvat' sammenhæng, men ikke i en 'lovmæssig' afhængighed af hinanden« (PE 49/37). Med »adækvans « støder vi på endnu et af de sværeste begreber i den weberske teori. Hvis man ville undersøge disse bestemmelser i detailler, så måtte man faktisk, som Turner/ Factor nylig har gjort $\operatorname{det}^{7}$, efterspore den daværende retsvidenskabelige diskussions indflydelse på idealtypelæren i Tyskland. På det citerede sted bliver begrebet imidlertid mest anvendt for at sætte en økonomis »kapitalistiske form «, altså strukturtypen, i forhold til »kulturen «, altså overbygningstypen II. »Adækvans « skal, som Weber siger (PE 83/54), udtrykke eksistensen af et »åndeligt slægtskab « mellem indholdet i den asketiske protestantisme og den »materielle«, altså strukturelle side af den kapitalistiske samfundsorden. Efter alt at dømme henviser »åndeligt slægtskab « til det samme indlysende forhold: Den objektive proces af kapitalistisk reproduktion havde næppe kunnet finde udbredelse og varighed, hvis der ikke også fandtes struktur-adækvate værdiideer, som var inkorporeret i motiverne og tænkemåderne hos de struktur- og kulturbetydende grupperinger, hvis ikke hos flertallet af individer i det hele taget. En strukturel adækvat etos henviser således til hverdagsmæssigt anerkendte og/eller inderliggjorte værdiideer, som for det enkelte subjekt gør udførelsen af de for den strukturelle organisation formålstjenlige handlinger til selvfølgeligheder eller sågar pligter. Mistanken om, at en weberianer allerede hermed skulle være kørt fast i en borgerlig værdikonservatisme, rammer naturligvis lige i den blå luft. Det vil være let at modgå en sådan mistanke med henvisninger til Webers overvejelser om den fundamentale omvæltning af kulturværdiideer samt med den indsigt, at den weberske logik og metodologi ikke i sig selv giver grunde, der afskærer blikket fra alternativer til en gennemsat »adækvat etos «. »Adækvans « fører altså i sidste ende til området for unders $\emptyset$ gelser af socialkarakterer eller, som Weber siger, »folkekarakterer«.

2) Helt konsekvent måtte »meningsdiskrepans « (Sinndiskrepanz) så anses for den grundrelation, der kendetegner traditionalismens forhold til

7. St. P. Turner/R.A. Factor: Objektive possibility and Adequate causation in Webers Metodological writings, in: The sociological Review 29, nr. 1, 1981, s. 5ff. 
strukturtypen. Weber vælger ikke dette begreb. Men den traditionalistiske etos bliver af ham ikke kun bragt i forhold til den asketiske protestantisme; der findes derudover en række argumenter, som skal klargøre den katolske $\varnothing$ konomiske etiks manglende overensstemmelse med den tilblivende kapitalismes strukturelle organisation.

3) Bemærkelsesværdig finder jeg under alle omstændigheder den ejendommelige logiske status, som Weber vil tilskrive adækvansrelationen. »Adækvans « skal skelnes fra »lovmæssig afhængighed « (jvf. ovenfor). Som jeg ser det, har Weber på dette sted til hensigt at foretage afgrænsninger i to retninger:

a) På den ene side vender han sig mod vulgærmarxismen, som tyder ideer i en énsidig kausal afhængighed af den strukturelle basis. Naturligvis er også Weber bekendt med det forhold, at der fra det samfundsmæssige heles organisationsprincipper udgår kausale indvirkninger på hvert enkelt subjekts tænkning og handling. »Den nuværende kapitalistiske samfundsorden er et uhyre kosmos, som den enkelte er født ind i og som for den enkelte, i det mindste som enkelt, er givet som et faktisk uforanderligt bur, som han må leve i« (PE 37/30). Men den samlede konstellation af idealtyper kan ikke indsnaevres til kausalrelationen. Weber ville med rette gå imod enhver $\emptyset$ konomistisk subjektteori, hvor tænkningen og handlingen hos de enkelte personer (f.eks. som karaktermasker) i ekstreme tilfælde udelukkende behandles som logisk implikation af sætningerne om reproduktionskredsløbet og dets stadier.

b) Omvendt kan Webers tænkning heller ikke forenes med den type ansatser, som mange fortolkere mærkværdigvis ellers får ud af hans protestantismetese, dvs. alle forsøgene på at forklare opståelsen af sociale systemer som kapitalismen alene ud fra virkningen af ideer og tænkemåder. En logisk kirurg, f.eks. en sprogfilosof fra Oxford, kunne sikkert påpege den mangelfulde logiske struktur i adækvansbegrebets mellemstilling hos Weber. Er meningen med dette begreb at udtrykke en funktionalitet, der er forskellig fra kausalitet; er der tale om nødvendige, men ikke tilstrækkelige betingelser for strukturforhold? Drejer det sig om en intentionalitet, der ikke kan føres tilbage til kausalitet? Eller om empiriske hypoteser af arten: Indholdene $\mathrm{a}, \mathrm{b}, \mathrm{c} \ldots \mathrm{n} \mathrm{i}$ et bestemt etos kræver - $\mathrm{i}$ forhold til alternativer eller $\mathrm{i}$ forhold til et historisk tidligere orienteringssystem snarere strukturelle forhold af typen $\mathrm{k}$ ? - Jeg lader dette felt for videre efterforskning ligge.

4) På steder, hvor Weber for engangs skyld eksplicit behandler strukturtypen, bestemmer han den ikke bare tilfældigt som »kapitalistisk basis«, hvorpå kulturen beror (PE 83/54). Basis-overbygnings- 
relationen hører således også til bestemmelsen af forholdet mellem idealtyperne.

Der kan muligvis rejses tvivl om, hvorvidt de tre idealtyper i Webers behandlingen af protestantismetesen er dannet strengt efter reglerne i hans metodologi. At jeg har forstærket undertoner og foretaget ændringer er mig klart, og at protestantismetesens angivelige krav på at have opdaget den afgørende faktor for kapitalismens opståen dermed er blevet uholdbart, har allerede Weber selv sagt. Det drejer sig for ham kun om de religiøse indholds medvirken i den kapitalistiske udvikling (PE 83/54). Under en kritisk teoridannelses synsvinkel taler imidlertid intet af dette mod den vægt, som kan tillægges det overgribende argumentationsforløb i Webers protestantismetese. Jeg tænker her ikke så meget på den ikke særlig strikte idealtypedannelse, men mere på den skitserede form for relationering af de tre typer. Denne skænker de religiøse doktriner og tænkemåder afg $\varnothing$ rende opmærksomhed i overensstemmelse med programmet. Men deres rolle bliver behandlet i en argumentationsramme, som fastholder muligheden og nødvendigheden af at skelne mellem strukturelle og kulturelle aspekter af den samfundsmæssige realitet, sågar i specifik betydning som en totalsamfundsmæssig reproduktionsproces med kernestrukturelle bestemmelser (»formelt frit arbejde«) i forhold til den »kultur« som hviler på dem. Følger man disse forudsætninger konsekvent, så har samtlige relationeringer deres fokus, sidste relationspunkt, »grund « i basisbestemmelser. Det gælder især for de subjektrelaterede udsagn. Alligevel holdes muligheden åben for at forfølge meget forskelligartede relationer til basis og momenterne indbyrdes uden at forfalde til den flade økonomisme og vekselvirkningsmetaforernes hjælpeløshed. Derudover står hele argumentationsstrukturen i et godtgjort eller efterviseligt forhold til historiskempirisk materiale. ${ }^{8}$ Mange samfundsteoretikere arbejder bevidst eller implicit med grunddistinktioner mellem basis og overbygning, struktur og kultur, subjektive og objektive samfundsmæssige faktorer. Lige så mange betjener sig af disse distinktioner på den mest grovkornede måde og uden bevidsthed om karakteren af den relationering, som hersker mellem de momenter som de dermed opererer med. Konstellationen af idealtyperne i protestantismeteorien betyder for mig en artikulerbar og fleksibel argumentationsfigur omkring disse problemer - en argumentationsfigur, som tilmed forbliver åben overfor empirisk materiale.

Bliver Weber på denne måde modelleret om til marxist? Bestemt nej. Jeg har blot villet pointere og idealisere den særlige form for anknytning til

8. Noter om hvordan forklarende udsagn indgår i konstruktionen, må jeg forbeholde andre arbejder om »kontekstforklaringer« til forskel fra »konneksforklaringer«. 
marxistiske motiver ved udviklingen af protestantismetesen. At Webers teori, som er opbygget over den målrationelle adfærd som elementær handlen og som er udviklet i relation til værdier, er ganske anderledes centreret end den marxske, er allerede forlængst blevet klart. Weber eller Marx? Det er et spørgsmål, som ikke duer til andet end de rituelle distanceringsøvelser, som mange parter og kredse forlanger af den, som angiver de dimensioner, hvori sammenligningen skal finde sted. Hvad angår protestantismetesen, så forstår jeg idealtypekonstellationen som et frugtbart eksempel på bearbejdningen af problemer, som også marxister fortsat har tilbage at behandle. Men det er et eksempel, der imidlertid for subjekteoretiske erkendelsesinteresser har sin afgørende grænse der, hvor det drejer sig om »folkekarakteren«, dvs. der, hvor det mere vidtrækkende drejer sig om de socialstrukturelle forudsætninger for en subjektivitet, der er istand til en selvstændig deltagelse i omformningen af de socialstrukturelle forhold. I dette tilfælde forekommer det mig mere lovende at gribe tilbage til Hegel, som står meget nærmere Marx.

(litteraturliste fortsat fra side 50)

Lowi, Th.J., 1964: Ein neuer Bezugsrahmen für die Analyse von Machtstrukturen. Optrykt i: Narr, W.D., Offe, C. (Hrsg.), 1975: Wohlfahrtsstaat und Massenloylität, Köln/Berlin West

Mickler, O., 1981: Facharbeit im Wandel. Frankfurt/Main

Müller, W., 1973: Der Pluralismus - die Staatstheorie des Reformismus, i: Doeker, G., Steffani, W. (Hrsg.): Klassenjustiz und Pluralismus, Hamburg

Scharpf, F.W., 1974: Krisenpolitik, i: Oertzen, P.v., Ehmke, H., Ehrenberg, H. (Hrsg.): Thema: Wirtschaftspolitik, Bonn-Bad Godesberg

Scharpf, F.W., 1976: Wirtschafts- und Gesellschaftsstruktur in der Bundesrepublik Deutschland. Thesen zum Referat auf dem Kongress der IG Metall »Krise und Reform der Industriegesellschaft «, Manuskript

Schiller, K., 1968: Konjunkturpolitik auf dem Wege zu einer Affluent Society, i: Schwedler, R., Föhrenbach, W. (Hrsg.), Jahre der Wende. Karlsruhe

Shaiken, Harley, 1980: Neue Technologien und Organisation der Arbeit, i: Leviathan 2/1980 


\title{
Ungdomsprotest - »Ny subjektivitet«, modstand eller integration?
}

\author{
Lars Bjфrnshauge
}

\section{Indledning.}

Hensigterne med det følgende er

- at diskutere 80'ernes ungdomsuroligheder i relation til ungdommen generelt i de højtudviklede kapitalistiske samfund. Ungdomsprotesten har kraftigt manifesteret sig i Vesttyskland, men snart sagt alle de vesteuropæiske lande har i større eller mindre grad oplevet de ny protestformer. Det meste af bidraget vil basere sig på den vesttyske diskussion, der er blevet ret omfattende.

- at belyse »ungdomsproblemernes « grundliggende samfundsmæssige karakter, det vil sige indskrive dem i en sammenhæng med kvalitative udviklinger i reproduktionsforholdene.

- at bidrage med teser til diskussionen af sammenhængen mellem unge, ungdomsprotest, ungdommens samfundsmæssige integration og samfundsforandrende bevægelser.

På trods af diskussionens »importerede « karakter, mener jeg, at den også har udsagnskraft - omend modificeret - i en dansk sammenhæng. Hvis det hele kan bidrage til, at ungdomsprotesten og dens samfundsmæssige og politiske »signalfunktion « vil blive taget alvorligt, vil meget være nået.

80'erne blev en brat opvågnen for regeringskommisærer, ungdomsforskere og journalister. I kølvandet på studenteroprøret var klicheer som »någeneration « blevet hverdagskost til beskrivelse af de sene 70'eres ungdom. Så »pludselig « ved indgangen til 80'erne brød helvede løs. Grupper af unge stod radikalt af samfundet. Husbesættelser, ta'-selv aktioner, kampe for frie, selvforvaltede ungdomscentre og i det hele taget unges uforholdsmæssigt store deltagelse ${ }^{1}$ i alternative livsformer, bevægelser og nye sociale bevægelser var blevet unges måde at manifestere sig på. I det følgende vil disse fænomener blive betegnet ungdomsprotest, og skal som sådan forstås som et potentiale indenfor ungdommen. Ungdomsprotesten tematiserer grundliggende samfundsmæssige forandringer ${ }^{2}$. I forlængelse heraf bliver

1. Brand s. 157, Eckert s. 143, Dörre \& Schäfer s. 141.

2. Dörre \& Schäfer s. 136. 
ungdomsprotesten et politisk, socialpsykologisk fænomen, hvor dele af ungdommen mere eller mindre organiseret, men trods alt i gruppesammenhæng offensivt, aggressivt, fantasifuldt og spontant ytrer deres utilfredshed med mangler, »ubehag « og »ikke-tilfredsstillelse « af menneskelige og samfundsmæssige behov og samtidigt forsøger at gøre noget ved det her og nu'.

I det følgende fors $\varnothing$ ges dette protestpotentiale identificeret, dets samfundsmæssige baggrunde blotlagt og det forsøges indskrevet i en samfundsforandringssammenhæng, for sluttelig at antyde ungdommens integration som samfundsproblem.

\section{II »I gaderne stiger feberen« \\ - ungdomsprotestens praksis! ${ }^{4}$}

Som antydet er ungdomsprotesten først og fremmest et storbyfænomen. Mest kendt er begivenhederne omkring autonome ungdomscentre i Zürich og husbesættelser i Berlin og Amsterdam. At disse byer repræsenterer de mest spektakulære begivenheder bør ikke bortlede opmærksomheden fra, at der er tale om langt mere udbredte fænomener.

Udgangspunktet for de radikale ungdomsgruppers udfordring af »normalsamfundet « har været kampen for frie, selvforvaltede rum i storbyerne, altså umiddelbart en kamp om $\mathrm{m}^{2}$. Den autoritære omstrukturering og gennemfunktionalisering af storbyerne efterlader overalt huller - tomme huse, forladte fabriksbygninger og udtjente kontorhuse, som okkuperes og erklæres for befriede rum. Bag denne kamp om plads skjuler der sig et helt register af behov, ønsker, protest og kritik, og et helt program for eksperimenter med arbejds-, bo-og samværsformer og sociale relationer.

De radikale unges program og praksis lader sig begribe som sub-og modkulturel. ${ }^{5}$ Kraftigt inspireret af punk-kulturen udvikles specielle stiltræk og symbolikker. Klædningsmæssig, sproglig og musikalsk tilegnelse og omformning er karakteristisk.

I deres miljøer eksperimenteres der med samlivsformer kraftigt influeret af kollektiv- og kvindebevægelsens landvindinger. Kønsrollerne forsøges ombrudt, ligesom klare anti-elitære, anti-autoritære og anarkistiske værdier er fremherskende.

\footnotetext{
3. Bopp s. 177ff.

4. Indenfor rammerne af dette bidrag er det overhovedet ikke muligt blot rimelig autentisk at gengive ungdomsprotestens praksis. Der henvises til: Aust \& Rosenbladt, Bacia \& Scherer, Brandes \& Schön, Breyvogel, Haller, Jensen, Madsen m.fl. Müller-Münch, for et kort rids se Bjørnshauge.

5. Nærmere om subkulturanalyse: Bay, Hebdige, Illeris m.fl. og Mørch.
} 
Basisdemokratiske beslutningsstrukturer forsøges afprøvet, hvilket kommer til udtryk også i de mere »organiserede « husbesættermiljøer i Berlin og Amsterdam. På trods af at der her er involveret flere tusinde unge er der udpræget autonomi for de enkelte enheder, og man vil lede forgæves efter ledere, talsmænd og »pinger «.

Centralt er behovet for selvbestemmelse defineret som modsætning til »voksensamfundets « gennemregulering og omklamring af de unge. Der er tale om en nærmest total afvisning af værdigrundlaget for den dominerende livsform. De afviser overvågning, hvadenten den har skikkelse af forældre, pædagoger, lærere, socialarbejdere eller politifolk, og insisterer på at »vi kan selv«.

Dette gælder i forhold til arbejde, politik og kultur. Kritikken af lønarbejdet er kontant. Fremfor at tilbringe livet ved et fremmedbestemt, monotont og psykisk ødelæggende lønarbejde prøver de at »arbejde« i deres erobrede rum, hvor de selv bestemmer hvor, hvornår, hvordan og til hvilket formål deres produktive og skabende aktivitet skal anvendes. De forsøger at indfri deres radikale krav til arbejdet, det skal være selvorganiseret, meningsfyldt samt personligt og socialt udviklende.

Ligeledes fors $\emptyset$ ger de at overvinde hverdagslivets opsplitning ved at integrere arbejde, fritid, politisk arbejde og udvikling af sociale relationer. Idealet er et hverdagsliv præget på en gang af selvbestemmelse, kollektivitet, solidaritet og befriet for konsumtvang og gennemrationalisering.

I deres aktioner og aktiviteter ligger også en radikal kritik af traditionel (venstrefløjs-) politisk praksis. Politik på den traditionelle måde har disse unge prøvet og der er ikke høstet brugbare erfaringer ad den vej. De udvikler deres egen politiske praksis, hvis første karakteristikum er action!. Med udgangspunkt i den opfattelse at politik er noget man skal kunne have sig selv med i, bliver politik og politisk aktion først og fremmest noget der skal være sjovt, noget med gang i, hvor fantasi, spontaneitet og uberegnelighed er væsentlige ressourcer. Det er den enkeltes deltagelse der er det centrale, ikke noget med at lade sig repræsentere, ingen forhandlere, ingen ledere.

Dette ultrakorte omrids af kritik- og protestpunkter og konkrete praksisser tegner billedet af et forsøg på at etablere en helt anderledes livsform, med et helt andet værdigrundlag end det dominerende i samfundet og den herskende kultur.

Dette lynhurtige rids er naturligvis for generelt og idealiserende. Et par forbehold bør imidlertid være tilstrækkeligt i denne sammenhæng. For det første bliver disse frirum hjemsøgt af ligepræcis sådanne samfundsmæssige, sociale og psykiske problemer som ikke får lov at blive bragt til 
udtryk på en relevant måde i »normalsamfundet « og dets institutioner. ${ }^{6}$ $\mathrm{Og}$ for det andet bidrager den generelle kriminalisering og daglige repression $^{7}$, som disse frirum ofte er genstand for, til at de får karakter af »fæstninger « $\mathrm{i}$ mere end en forstand. Angst og paranoia kan her få rimelige funktionsbetingelser, ligesom militans bliver en dyd i sig selv, hvilket i mange tilfælde kan føre til afskalning af mere »bløde « grupper efterhånden som »fæstningskuller« og macho-prægede »streetfighter«-tendenser udbredes. ${ }^{8}$

Det ovenstående skulle antyde, at det vil være en kraftig forkortning at uddefinere ungdomsprotesten til at være udtryk for pubertetsproblemer og apolitiske ungdomsgriller. I det hele taget vil det føre ind i en blindgyde at diskutere disse fænomener som generationskonflikt i traditionel forstand og som udtryk for specifikke ungdomsproblemer. Alene det faktum at regeringskommissærerne overalt i Europa har kastet sig over at forklare disse forhold som ungdomsproblemer bør vække til eftertanke.

Bureaukraters, politikeres og mediefolks iscenesættelse af husbesættelser m.v. som uregerlige minoriteters værk kan medføre, at de behov, ønsker og problemer de unge tematiserer, kan udgrænses som minoritetens problemer. Dvs. at de samfundsproblemer og »store spørgsmål«, som tematiseres bliver fjernet fra samfundets overflade. Denne »etnologisering " $^{9}$ af dele af befolkningen kan også funktionalisere de radikale unge til syndebuk, hvad der jo er rimelig efterspørgsel efter for tiden. Derved operationaliseres de radikale unge til at blive objekt for assimilerede befolkningsgruppers projicering af egne angstfølelser, indestængte og fortrængte behov ${ }^{10}$.

I øvrigt er og forbliver det uden mening at tale om ungdom som en homogen størrelse. Alene de mangfoldige subkulturer vidner om forskellighed, ligesom der ikke mindst i disse år er tale om en kraftig differentiering i de unges livsbetingelser. Men dette betyder på den anden side ikke, at der er grund til at undlade at bore dybere $\mathrm{i}$ hvad det egentlig vil sige at være ung og skulle blive voksen i de vestlige samfund $\mathrm{i} \mathrm{dag}^{11}$.

At diskutere ungdomsprotesten i dens rette sammenhæng vil herefter betyde at tage udgangspunkt ikke så meget i deltagernes alder og udviklingspsykologiske status, men derimod i deres ønsker, angstformer, behov, protest og kritik.

6. Hornstein s. 200 og 207.

7. Jvf. f.eks. Härlin.

8. Jvf. Rabehl.

9. Roth. s. 95.

10. Wirth. s. 221.

11. Jvf. afsnit IV \& V. 
Der står her klart, at der i ungdomsprotesten tematiseres problemer og behov, som kun for en ringe del kan betragtes som ungdomsspecifikke ${ }^{12}$. Langt snarere er der tale om ønsker og længsler som ethvert fornuftigt menneske burde have. Det, som de radikale unge i deres protest og praksis sætter til diskussion er samfundet, dets livsform og grundlæggende værdier: byernes $\emptyset$ delæggelse af livsbetingelserne, den rigide konsumisme, familiestrukturen, miljøødelæggelsen, arbejdsbegrebet, politikbegrebet osv.

Ungdomsprotesten bliver herefter til samfundsdiskussion og ikke mindst fremtidsforskning.

Men hvordan kan det forklares, at grupper af unge her i 80'erne går så kraftigt på angreb på »normalsamfundet « og dets værdier, og hvordan kan det forklares at de radikale gruppers aktioner og det de står for, ikke længere lader sig uddefinere som en marginal minoritets værk, men tværtimod støder på sympati hos meget brede grupper i ungdommen? ${ }^{13}$

\section{Exkurs: Fra'68 til'80.}

I diskussionen om studenteroprøret, 68'erne og dagens ungdomsprotest verserer en række myter og fordomme. Det følgende skulle helst bidrage med afklaring.

Det er vigtigt at påpege en række forskelligheder mellem de to »oprør«. Først og fremmest finder de sted på forskellige tidspunkter, på forskellige stadier af kapitalismens udvikling og i forskellige samfundsmæssige, politiske og kulturelle situationer. Fra 1968 til 1980'erne har der fundet et skift sted i befolkningens og specielt ungdommens opfattelse af samfundet og dets fremtid. Hvor der i 1968 herskede fremskridtsoptimisme og enighed om at den teknisk-industrielle udvikling ville tjene menneskeheden til bedste, hvis der blot blev grebet korrigerende ind (reformer) under presset fra studenter og arbejderklasse, hersker der idag udbredt fremskridtsangst, troen på at kapitalismen (og socialismen for den sags skyld også) i dens videre udvikling kan tackle de problemer, som den selv avler, er ikke længere tilstede i brede dele af befolkningen og især ungdommen. Hvor der i 1968 var udbredt enighed om betydningen af uddannelse, af de politiske institutioner og rationel diskussion og teori samt tillid til at samfundsudviklingen kunne befries for sine vildskud gennem venstrefløjsindividernes »march gennem institutionerne« er situationen blandt rebellerne idag en helt anden. Optimismen og troen på mulighederne for

12. Ziehe i Bahr.

13. Bacia \& Scherer, Kuntz og Jugendwerk der Deutschen Shell. 
demokratisk, skridtvis forandring gennem de demokratiske institutioner er nu erstattet af billedet af et fuldkomment stivnet politisk system, som hverken formår at levere rimelige bud på fundamentale globale problemer (atomar apokalypse, miljøødelæggelse) eller optage »nye problemer« på dagsordenen. ${ }^{14}$

I denne sammenhæng afskrives reformillusioner og for store dele af de radikale unge er det indtrykket at det er »institutionerne der har marcheret igennem hovedet på 68'erne «.

Ligeledes er der sket en forskydning i »fjendebilledet«. Lidt stiliseret: fra en kamp indenfor samfundet imod kapitalen og om staten, til en kamp udenfor samfundet imod staten og dens tvilling kapitalen, medgden samtidige understregning at hverken kapitalisme eller socialisme byder på rimelige udviklingsmuligheder, de reducerer begge mennesket til arbejdsog konsumkvæg! ${ }^{15}$

Udgangspunktet for protest er så at sige også rykket tættere på individerne. Idag er det ikke længere sådan, at forestillingerne om revolutionen og »den store dag « og kampen for den kan føres sideløbende med at privatlivet og subjektive behov holdes udenfor. Nu er udgangspunktet blevet mere subjektivt og udspringer af de hverdagslige livserfaringer og livsbetingelser. Det er primært dem der skal ændres og helst straks. Hermed er det missionæriske offerberedskab og avantgarde-tænkning blevet afløst af den erkendelse at politik og privatliv er uadskillige.

Det betyder også, at der ikke som før er tale om en primært »abstrakt « teoretisk kritik af samfundet og livsmulighederne, men langt mere en elementær praktisk kritik, hvor det drejer sig om den konkrete realisering af alternative forestillinger ${ }^{16}$. Protestpotentialet er idag også mere bredt i sin sociale rekruttering. Hvor det tidligere var primært studenter og højere mellemlag der førte an, er det i dag socialt meget heterogene grupper der går i aktion og de har resonans i meget brede dele af ungdommen. ${ }^{17}$

Selvom protesten idag slagordsmæssigt kan beskrives som antietatistisk, $\emptyset$ kologisk, mere emotionel, mere anarkistisk og mere pessimistisk ${ }^{18}$ end i 1968 så har bl.a. Hollstein leveret overbevisende argumenter for at dagens ungdomsprotest også står i kraftig gæld til bl.a. 60'ernes hedonistisk

14. Behr. s. 15 .

15. Hollstein i Haller s. 203.

16. Schäfers s. 140 og Behr s. 144.

17. Lessing \& Liebel, Allerbeck, Hollstein i Haller, Dörre \& Schäfer.

18. Richter s. 197. 
orienterede modkulturer i USA, studenteroprøret i Europa og kvindebevægelsen. Ungdomsprotesten i dag videreudvikler det værdigrundlag, de basisdemokratiske eksperimenter og protestformer og alternative livsformer som udvikledes i kimform i 60'erne og 70'erne. Mere rimeligt forekommer det måske at sige, at ungdomsprotesten manifesterer udbredelsen af de ovennævnte former for »afvigende adfærd « og »udenomsparlamentarisk interessevaretagelse « til bredere dele af ungdommen idag.

\section{Kapitalistisk samfundsmassiggфrelse og unges situation.}

De kapitalistiske samfundsmæssiggørelsesprocessers fremskredne karakter og deres indtrængen i snart sagt alle samfundsmæssige sfærer fremkalder mangfoldige krisesymptomer i de vestlige samfund, og disse krisesymptomer har allerede længe ikke kunnet defineres som økonomisk krise. Langt snarere er der tale om en enhed af økonomisk, politisk, social og kulturel krise ${ }^{20}$, eller simpelthen om en krise for den industrielle civilisation.

Der er efterhånden rimeligt belæg for den påstand, at der i og med efterkrigstiden er tale om kvalitative udviklingsspring indenfor de kapitalistiske produktions- og - ikke mindst - reproduktionsforhold. De første er blevet til genstand for omfattende forskning, analyse og teoriopmærksomhed, mens det for de sidste gælder at der efter min opfattelse ikke er ofret tilstrækkelig opmærksomhed på dem.

Dette bliver imidlertid et problem, da det netop er herindenfor at de kvalitative udviklinger gør sig gældende ${ }^{21}$.

Den kvalitative ændring af produktionsprocessen, som Tayloriseringen af arbejdet var udtryk for, og produktionens omlægning fra industrigodeproduktion til produktion af masseforbrugsgoder har haft omfattende følger for hele reproduktionsprocessen. Denne af bl.a. Hirsch betegnede Fordske samfundsmæssigg ørelsesform giver sig udtryk i de kapitalistiske varerelationers »æden sig ind « i førborgerlige relationer, traditioner, normer og værdiorienteringer, som hidtil i væsentlig grad har struktureret re-

19. Jvf. Hollstein 1981 og 1983.

20. Hirsch.

21. Jeg gør mig bestemt ikke til talsmand for, at produktions- og reproduktionsbetingelserne kan analyseres uafhængigt af hinanden. Tværtimod er der tale om, at udviklingen i produktionssfæren afgørende determinerer reproduktionsforholdene, og at netop dette med accelerende styrke slår igennem indenfor de sidste 20-25 år, jvf. Hirsch, Brückner u.a. 
produktionsprocessen. Disse »overleverede « »institutioner « har kapitalen hidtil kunnet udbytte som en »gratis-produktivkraft « ${ }^{22}$ som har været med til at billiggøre reproduktionsprocessen, at stabilisere socialisations- og integrationsprocesserne. Den tiltagende opløsning af disse førborgerlige reproduktionsformer betyder nu, at de i stigende grad skal produceres samfundsmæssigt (og det vil sige statsligt), ligesom det iøvrigt i tiltagende omfang gælder for produktionens natur-grundlag ${ }^{23}$.

Den Fordske samfundsmæssiggørelsesforms mest markante kendetegn er en gennemgribende gennemkapitalisering af reproduktionssfæren. Reproduktionsprocesserne organiseres rumligt og tidsmæssigt, de tayloriseres, og det betyder ikke blot segregering af hverdagslivet i adskilte rum, men også at de medmenneskelige relationer bliver sat på vareform - depersonaliseres og sagliggøres.

Som følge af denne gennemkapitalisering forandres ligeledes de sociale relationer, familiens funktionsbetingelser, mellemmenneskelige interaktionsformer, kulturelle traditioner og samfundsmæssige tydningsmønstre. Dette betyder grundlæggende forandrede socialisationsbetingelser, og ikke mindst sætter kapitalistiske samfundsmæssiggørelsesmekanismer sit præg på menneskenes subjektive, indre strukturer.

Det kapitalistiske samfunds centrale socialisations- og integrationsagenturer - familie, skole og »ideologi« - angribes af samfundsmæssige erosionstendenser. Den accelererende opbrydning af traditionelle netværk og miljøer, udtyndingen af sociale relationer, hverdagslivets opsplitning og gennemfunktionalisering lader den borgerlige kernefamilie undergå en flerdimensionel forandringsproces. Dels aflaster statsliggørelsen af mangfoldige materielle - tidligere "private - reproduktionsydelser familien. Og dels efterlader gennemrationaliseringen og depersonaliseringen af de »offentlige « relationer samt den dominerende livsforms karakter af privatistisk isoleret konsumfællesskab, familien med et stigende pres med hensyn til indfrielsen af emotionelle behov, som ikke finder »udløsning « $\mathrm{i}$ det $\gg$ offentlige « liv.

Herudover intervenerer det udenomliggende samfund på andre niveauer ind i familien. Professionaliseringen af opdragelsen foranlediger en tiltagende subjektiv følelse af pædagogisk dekvalificering og inkompetence hos forældrene. Ligeledes bidrager den samfundsmæssigt frembragte og medieindustrielt forstærkede norm- og værdirelativisme ind i familien, og det samlede resultat bliver en tiltagende social og psykisk rådvild-

22. Jvf. Parin \& Ziehe i Breyvogel.

23. Hirsch. 
hed hos forældrene ${ }^{24}$. Dette kompleks af overfordringer til familien giver sig udslag i omfattende opløsningstendenser - og kort sagt: »familiens krise «.

Familien er med andre ord ikke så gnidningsløst som tidligere i stand til at videregive de for den borgerlige socialkarakter relevante norm- og værdiorienteringer til de opvoksende generationer. Den borgerlige autoritære karakters socialisationsbetingelser undergraves, som følge af de omfattende samfundsmæssiggørelsesprocesser.

Også de statsliggjorte socialisationsapparater angribes af erosionsprocesser og dysfunktion. Den hastige samfundsforandring og nedbrydning af de kulturelle norm- og værdiorienteringer undergraver en af skolens vigtigste sammenholds- og gratisfaktorer: Med opløsningen af de tradierede kulturelle forestillinger, »selvfølgeligheder« autoritetsrelationer og verdens- og livsopfattelser mister skolen »aura « og bliver slet og ret skole - i betydningen anstalt for »tvangssocialisation $\ll,{ }^{25}$ hvilket giver sig udslag som en mangfoldighed af tilpasningsproblemer - samlet i begreberne: disciplin- og motivationskrise.

De ændrede socialisationsbetingelser lader sig iagttage som nogle nye norm- og værdiorienteringer, nye adfærdsformer og nye sygdomssymptomer hos de unge.

Der er således tegn på en løsnelse af de psykiske, identitetsmæssige bindinger til lønarbejdet. Dette giver sig udslag i en manglende tilpasning og underkastelse under lønarbejdets rigide funktionalisme, vanskeligheder med at internalisere arbejdsdisciplin og loyalitet, udbredt pjækkeri osv. De unge stiller i stigende grad »radikale « krav til arbejdet, nægter umiddelbart at indordne sig, og selv arbejdsløse tager ikke et hvilket som helst job. ${ }^{26}$

I uddannelsesprocessen og -situationen prioriteres mere umiddelbar selvoplevelse, hvis ikke undervisningen har relation til hverdagen mangler motivationen. Resignation, apati og ligegyldighed breder sig.

Udviklingen er udtryk for en forskydning af identitetsholdepunkterne væk fra lønarbejde og uddannelse og overimod fritidsaktiviteter, kammeratgrupper m.v. Der er kraftige tendenser til opbygning af »vandtætte skodder « imellem det »offentlige« liv i skole og på arbejde og på den anden side fritiden. ${ }^{27}$

Unders $\varnothing$ gelser af unges oplevelse af hverdagen udmunder i konklusioner, om at de oplever den som fremmedbestemt, fremmedgjort og gennemregu-

24. Ziehe \& Stubenrauch s. $69 \mathrm{ff}$.

25. Ibid. s. $115 \mathrm{ff}$.

26. Olsen \& Nielsen s. 334.

27. Jvf. Dörre \& Schäfer s. 91ff og Illeris m.fl. s. 144. 
leret, ligesom hverdagens opsplitning virker belastende. Alt $\mathrm{i}$ alt er der tegn på nye psykiske lidelser blandt fortrinsvis unge; lidelser der er karakteriseret ved følelsen af indre tomhed, manglende realitetsfornemmelse, manglende initiativ, manglende arbejdsglæde ${ }^{28}$.

Den samfundsmæssige organisering af unge i specielle rum, institutioner og »kulturer « i en (ganske vist køns- og klassespecifikt) stadig forlænget periode er en mere almen baggrund for udviklingen af »afvigende« adfærd, normer og værdier.

Således foregår identitetsdannelsesprocesser og socialisation i stigende grad i gruppesammenhænge, dels i de socialstatsligt organiserede »rum « (skole, institutioner m.v.) og dels i mere eller mindre selvorganiserede grupper. Disse sidste tilbyder en »ungdomssocialisation i eget regi«, som støtter de unge i deres opposition, emotionelle uligevægt og letter en ungdomsspecifik identitetsdannelse ${ }^{29}$.

Den mangesidede samfundsmæssige og statslige gennemregulering af individerne fra vugge til indtræden i voksenlivet gør samtidigt ungdommen til en specifik »sfære«, hvor de unge bliver »modtagelig for forskellige former for social indflydelse $\ll^{30}$. Den emotionelle åbenhed og eksperiment-lyst, som præger identitetsperioden gør ungdomsperioden til et socialt frirum, hvor de unge selv kan agere, skabe kulturer stile og symboler ${ }^{31}$.

At medie-, mode- og mainstreamkulturindustrien her har fundet ekspansionsmuligheder kan imidlertid ikke dække over, at der her er et spillerum for afprøvning af (sam)livsformer, biografiovervejelser og fremtidsspekulationer, som udvikles af de unge selv på trods af den udvendige regulering fra samfund og stat.

Statsliggørelsen af socialisationsprocessen, ungdommens institutionalisering i specielle rum og ungdomsperiodens forlængelse konstituerer således dels vanskelighederne med at internalisere en »tilpasning « af forventninger og behov, og på den anden side udviklingsbetingelserne for mere eller mindre »radikale « behov i f.t. uddannelse, arbejde og tilværelsen i det hele taget.

For brede dele af de unge gælder det, at den borgerlige dannelseskanon: flid, pligt, ydelsesberedskab (og først derefter konsum) ikke rigtigt indfan-

28. Olsén \& Nielsen s. 335.

29. Schäfers s. 136.

30. Wirth s. 221.

31. Madsen m.fl. s. 133. 
ger dem, men at de tværtimod kræver et godt, personligt udviklende og meningsfyldt arbejde, solidariske samværsformer i fritiden og i det hele taget et sikkert fremtidsperspektiv osv.

Ungdomsperiodens insulære karakter fremmer hermed udviklingen af forventninger, behov og værdinormer, som på sin side kommer mere og mere i modstrid med den samfundsmæssige realitet, de unge skal konfronteres med i voksenlivet.

Overfor $\emptyset$ nsket om det meningsfyldte arbejde står enten arbejdsløsheden eller det monotone, fremmedbestemte arbejde. Overfor behovet for selvbestemte, profitfrie samværsmuligheder i fritiden står eliteidræt og en forhåndsorganiseret og konsumtvingende mainstream-kulturindustri. Og indrammende det hele er der et helt register af globale problemer, der truer det sikre fremtidsperspektiv.

Alt i alt forøges gabet mellem subjektive behov og den samfundsmæssige udviklings realitet.

\section{V. »Ny subjektivitet «}

Hvordan omgås de unge så med disse perspektiver, hvilke overlevelsesstrategier producerer de? Er der tale om ødelæggelse og destruktion eller frisættes der også protestpotentiale?

Ziehe har fors $\emptyset \mathrm{gt}$ at fremhæve nogle træk i unges psykiske og kulturelle situation i dag, og hvilke bearbejdningsformer denne situation udvikler ${ }^{32}$.

Under overskrifterne »kulturel frisættelse og kulturel ekspropriation « er hans intention at begribe problemerne og potentialerne $\mathrm{i}$ det at være ung i dag. Den kulturelle frisættelse er begrebet for den omfattende frisættelse fra traditionelle kulturelle forestillinger, bånd og handlingsanvisninger, som er resultatet af gennemkapitaliseringen af reproduktionssfæren og samfundsmæssiggørelsen af hverdagslivet. Den kommer til udtryk i forældregenerationens samfundsmæssige dekvalificering, autoritetsrelationernes erosion og arbejdsetikkens forfald. I stedet opstår konturer af en »hedonistisk etik« - prioriteringen af nydelse, selvoplevelse, mening og selvrealisering.

Denne proces er dobbelt: på den ene side er den frigørelse fra en forudbestemt identitet og biografi, og på den anden side åbner den spillerum for kommerciel udnyttelse. Dette spillerum udnyttes dygtigt af ikke mindst medieindustrien med mangfoldigt - i sig selv både integrerende og desin-

32. Jvf. i det følgende Ziehe \& Stubenrauch. 
tegrerende - udbud af behov, »lykkeoplevelser «, »eventyr « m.v. Det bliver nu - i modsætning til tidligere i historien -muligt at forestille sig allemulige biografier, men samtidigt bliver disse nu kommercielt lanceret som kapitalistiske, forhåndsorganiserede tjenesteydelser.

Denne proces ser Ziehe som en kulturel ekspropriation af mulighederne for at gøre selvstændige erfaringer. Alt hvad man kan forestille sig er allerede besat med samfundsmæssigt tilgængelige erfaringer og tydninger.

Denne »slagmark « mellem kulturel frisættelse og ekspropriation sætter de unge på hidtil usete prøvelser og belastninger rent psykisk. Identitet er ikke mere noget på forhånd givet, og heri ligger der noget frigørelse, men på den anden side bliver de unge med en »åben « biografi, nu selv ansvarlige for deres identitet, psykiske situation og hele liv. Denne eksplosion i samfundsmæssigt producerede biografi- »tilbud « forstærker ydelsespresset og præstationsangsten hos de unge. De skal nu vælge mellem uendelige muligheder og konstant lurer følelsen af at have valgt forkert. Denne udvidelse af det »mulige « sætter sig let som en subjektiv belastning, netop fordi dette mulige ikke er reelt muligt for de fleste, men stadigvæk er du selv ansvarlig.

Dobbeltheden i denne proces viser sig i den samtidige tilstedeværelse af resignation, apati og insisteren på noget andet, emancipation og protest.

I denne proces, - enheden af frisættelse og ekspropriation -, som »indrammer « de unges psykiske og kulturelle situation ser Ziehe nogle dominerende måder psykisk at bearbejde situationen på.

For det første er forøget længsel efter subjektivering i de relationer de unge indgår i i hverdagen. De offentlige relationer - i skole, på arbejde, i.f.t. offentlige myndigheder m.v. - udvikler sig mere og mere målrationalt, og de mellemmenneskelige relationer bliver sat på vareform. Heroverfor stiger de unges behov for at opleve relationer, hvor de har sit selv med, hvor de kan blive beriget følelsesmæssigt og emotionelt. Dette gælder i skolen, på arbejdet, i fritiden og i f.t. politisk aktivitet.

For det andet er der tale om en forøget opmærksomhed omkring selvværdsfølelse. For Ziehe er spørgsmålet om selvværdet blevet den centrale psykiske problematik. Denne voksende sensibilitet overfor selvværdet giver sig til kende som en stigende evne til at registrere, hvad andre vil med een, altså en forøget opmærksomhed om relationers kvalitet.

For det tredie en motivationskrise, eller en legitimationskrise i det psykiske. Denne ytrer sig f.eks. igennem spørgsmålet: »skal jeg finde mig i det? «, et spørgsmål som ikke mindst opløsningen af autoritetsrelationerne har gjort det meget mere nærliggende at stille. Forældregenerationen 
fik at vide, »at sådan er det nu engang! « mens studenteroprørerne kunne spørge: »Er det legitimt?«. Legitimationskrisen viser sig også derved, at totalsamfundsmæssige problemer inddrages i de hverdagslige beslutninger (skal jeg virkelig i skole, på arbejde, det kan jo være ligegyldigt, hvis hele lortet ryger i luften i næste uge). Den borgerlige socialkarakter og internatiseringen af værdimønstre udelukkede sådanne overvejelser (du skal!).

Den fjerde bearbejdningsform ligger i kravet om involverethed,.. Personlige relationer, arbejde, undervisning, fritidsbeskæftigelse bliver vurderet efter hvorvidt man kan finde sig selv og hvorvidt de kan bidrage til et forøget selvværd.

Ziehes metapsykologiske og kulturanalytiske overvejelser kan vel næppe have status af teori, men de er i stand til at indfange nogle træk hos nutidens ungdom ${ }^{33}$, som kan sammenfattes således:

De kapitalistiske samfund befinder sig midt i en fremskreden kulturel og social opløsningsproces, der drives frem af kapitalistiske varerelationers og interaktionsformers »æden sig på« reproduktionssfærens førborgerlige traditioner, livs- og reproduktionsformer, og det i et omfang så det har karakter af en krise for samfundets »subjektbasis ${ }^{34}$. Specielt de unge inddrages i disse omvæltningsprocesser, qva deres placering i en identitetsmæssig og psykisk labil omstillingssituation (ligesom iøvrigt stigende dele af befolkningen (som følge af tvangsmobilisering, arbejdsløshed, ændrede familieforhold osv.)). Situationen er karakteriseret ved dels nye ekspropriations- og integrationsformer, repræsenteret ved medie- og bevidsthedsindustriens »interne « imperialisme og de socialstatslige socialisationsagenturer, og dels ved den samtidige produktion af »overskridende behov og fordringer $«,{ }^{35}$ frisættelse af emancipatoriske muligheder og handlingsforestillinger. ${ }^{36}$.

Herudfra kan der forsigtigt tegnes konturer af en ungdom (og ikke alene ungdom) »udstyret« med en ny subjektivitet - karakteriseret ved på den ene side en ikke-internalisering af de traditionelle norm-og værdiorienterinter,

33. Den voldsomme interesse og diskussion omkring Ziehe (\& Stubenrauchs) vidner trods alt om, at »der er noget om snakken« - lærerværelserne er blevet sat på den anden ende! Jeg er ikke gået ind i diskussionen om Ziehe's tidlige arbejder, hvor diskussionen har været centreret om tidlige brud og frustrationer. Efter min opfattelse har diskussionen til dels været forfejlet. Dette har noget at gøre med at fortvivlede pædagoger og lærere her har kunnet finde noget, at hænge de daglige frustrationer op på. At man på denne måde kan frikende sig selv, bør manden i princippet ikke lastes for!! For nærmere om diskussionen og kritikken se Baethge, Lindner og Nielsen.

34. Brückner u.a.

35. Hirsch.

36. Det er helt givet, at de kulturelle frisætnings- og ekspropriationsprocesser giver anledning til omfattende anomirekationer, eskapisme og selvødelæggelse. 
handlingsanvisninger, autoritære relationer, pligt- og ydelsesdyder, underkastelses- og »tilpasnings«-rationaler og dispositioner for driftsafkald og behovsudskydelse - kort: den borgerlige autoritære socialkarakters grundtræk, og på den anden side en hedonistisk orienteret, selvrealiserings- og selvværdsbetonende værdi- og adfærdsorientering.

\section{Rebellerende unge og det tavse flertal?}

Hvis vi i forlængelse af det foranstående går ud fra, at den kulturelle situation er karakteriseret ved opløsning, værdirelativisme, socialisations- og integrationskrise, bliver ungdomsprotesten at betragte, som et signal om disse tendenser. De rebellerende unge reagerer »seismografisk « på disse udviklinger, »udstiller «, forvrænger og forstørrer gennem deres kulturelle praxis (klædning, happenings, grafiti osv.) deres utilfredshed og kritik af livsbetingelserne.

I fraværet af et »bevidsthedsmæssigt filter«, i form af traditionelle verdens- og livsanskuelser, handlingsanvisninger og erindringer om materiel knaphed, reagerer de unge langt mere sensibelt på de samfundsmæssige forandringer. De unge er i modsætning til de voksne ikke i stand til at stabilisere sig på hverdagens overflade, og således holde mistanken om, at meget af det hverdagen går med slet og ret er vanvittigt, på afstand ${ }^{37}$.

Således bliver spørgsmålet om, »hvad meningen er med det hele? « mere nærliggende at stille sig selv og ikke mindst samfundet. Som sådan må ungdomsprotesten ses som en umiddelbar, ufiltreret reaktion mod den gennemorganiserede meningsløshed. Eller med andre ord en insisteren på mening: meningsfyldte gøremål, meningsfyldt arbejde, meningsfyldte sociale relationer og - mere subjektivt - oplevelse af intensitet, selvbestemte og selvforvaltede sammenhænge. ${ }^{38}$

Ungdomsprotesten bliver således på een gang kritik af den samfundsmæssige modernisering og af de ældre generationers egen »disciplinerings- og ydelseshistorie $\ll^{39}$ samt vigtigst en annoncering af behov, som har dækning hos brede dele af ikke blot unge.

Dette sidste skal her ganske kort sandsynliggøres. Umiddelbart vidner udbredelsen af ungdomsprotestens subkulturelle stiltræk og symbolikker

37. Ziehe i Bjerg \& Elle.

38. Jvf. Ziehe \& Stubenrauch s. 227ff.

39. Ziehe i Bahr. s. 155. 
om en ikke ringe resonans indenfor ungdommen (jvf. f.eks. udbredelsen af graffiti).

Mere gods er der i de efterhånden talrige »ungdomsundersøgelser«. Selvom det ikke er uproblematisk at skulle hente generelle tendenser ud af disse $^{40}$, så kan der dog peges på nogle:

- omfattende ændringer i norm- og værdiorienteringer

- en afstandtagen fra voksengenerationens livsform og livsstil

- at et stort mindretal (10-25\%) betragter sig selv som stående udenfor den herskende kultur

- at flertallet af de unge ser pessimistisk på fremtiden

- at jo mere pessimistisk - jo mere aktiv i kampen for ændringer af de umiddelbare livsbetingelser (forandring er mulig)

- at der selv hos arbejderungdom er tale om en høj grad af sympati med hele spektret af protestbevægelser, lige fra husbesættere, via fredsbevægelse og til øko-bevægelse.

- at det ikke så meget er den sociale baggrund, der determinerer »protestholdninger «, men mere ungdomsperiodens og uddannelsens varighed

- at der er en kraftigt dalende tillid til det politiske systems kanaler, og en ligeså tiltagende tro på andre former for politisk praksis.

Med andre ord: Det bliver stadigt mere umuligt at operere med vandtætte skodder mellem en marginaliseret, radikal minoritet og et tavst velintegreret flertal. Langt snarere er der tale om at den generelle grundstemning hos ungdommen, »at man ikke skal finde sig i hvadsomhelst, at det er nødvendigt at yde modstand og at et bedre, mere humant samfund burde begynde her og nu «, ${ }^{41}$ på hele ungdommens vegne annonceres af de rebellerende unge.

\section{Unge, ungdomsprotest og nye sociale bevagelser.}

De radikale unges kritik af »politik «, det politiske system, partierne og den traditionelle politiske praksis er allerede tidligere berørt ${ }^{42}$

Hos unge i almindelighed kan der iagttages kraftige tendenser i retning af »politikerlede«, relativ lav partipolitisk organiseringsgrad og lavere valgdeltagelse - i det hele taget indifferens. Men at fortolke dette i retning af en afpolitiseret ungdomsgeneration vil imidlertid være at gå galt i byen. Rimeligvis forholder det sig således, at det politiske system og de traditionelle

40. For kritiske overvejelser se Allerbeck \& Fischer.

41. Dörre \& Schäfer s. 63.

42. Jvf. den i note 4 nævnte litteratur. 
kanaler ikke har ret meget at byde på i forhold til de konflikter, problemer, behov og ønsker unge idag erfarer og oplever som eksistentielle.

I takt med partiernes udvikling i retning af »folkepartier «, uden afgrænset vælgerappeal, social basis og program, og »politikken« udvikler sig til ren og skær administration af »samfundsudviklingens behov og nødvendigheder « forbliver de problemer, som optager de unge ude af den praktiske politiks horisont.

Heroverfor står det så som en kendsgerning, at det ikke blot er de rebellerende unge, der finder det nødvendigt og helt legitimt at fors $\varnothing$ ge behov og interesser gennemsat ved udenomsparlamentarisk aktivitet, men at dét i stigende grad bliver ungdommens foretrukne politik-form.

Og dette kan ikke blot forklares udfra (manglende) egenskaber i de traditionelle politiske kanaler: Deltagelse i græsrodsbevægelser, alternative kulturelle manifestationer og sociale bevægelser tilbyder på mange måder samværsformer, aktionsformer og sammenhænge som modsvarer mange unges behov.

Således er alternativbevægelse, forsøgene med anderledes livsformer og alternativkultur organiseret på en sådan måde, at de så at sige tilbyder en forlængelse af ungdomsspecifikke samværsformer -gruppeorganiseret, solidarisk, selvbestemt osv.

Endvidere tilbyder deltagelse i alternativbevægelse og nye sociale bevægelser også løsningsmuligheder på de problemer unge står i midt i identitetsdannelsesprocessen og personlighedsudviklingen. Det stadigt stigende gab mellem på den ene side de systematisk producerede overskridende forventninger og behov - som unge »rammes « hårdest af -, og på den anden side de indsnævrede muligheder for at realisere disse behov »indenfor « den dominerende livsform, kan i det mindste her finde een mulig bearbejdningsform. Behovet for meningsfuld beskæftigelse kan kombineres med solidariske sociale relationer og modstands- og forandringstrang, og det med nogle konsekvenser som både rækker ud over ungdomsperioden og ud i samfundet.

Dette giver sig ikke alene udtryk i, at unge er det væsentligste rekrutteringsområde for alternativbevægelse og nye sociale bevægelser, men også i at brede grupper af unge nærer udbredt sympati for disse bevægelsers målsætning og aktionsformer.

Herefter kan der sammenfattes således: De omfattende samfundsmæssige forandringer - ikke mindst indenfor reproduktionssfæren - gør store dele af ungdommen »modtagelig « for kritik af den industrielle civilisation, for de målsætninger, modstandsformer og livsformer, der ligger indenfor ungdomsprotestens, alternativbevægelsens og de nye sociale bevægelsers felt. 
Ungdommens samfundsmæssige integration er herefter sat som et væsentligt samfundsmæssigt problem.

\section{Ungdommens samfundsmassige integration - problemer og perspektiver.}

Vi kan således fortolke udviklingen af de kapitalistiske produktions- og ikke mindst reproduktionsforhold som et kraftigt tab af traditionelt integrationspotentiale, der viser sig som

- omfattende tendenser til værdiforandring hos først og fremmest de yngre generationer. Det borgerlige samfunds værdikodex »fanger« ikke længere de unge og anfægtes af et nyt, hedonistisk og forandringsorienteret normog værdimønster, hvor først og fremmest spørgsmålet om selvbestemmelse, mening og subjektivering er centrale.

- en udbredt mistillid til den fortsatte teknisk-industrielle udvikling, legitimiteten af den statsadministrative handlen og det politiske systems deltagelsesmuligheder.

Denne udbredte desintegration er naturligvis ikke kun positiv -mht. emancipationsforhåbninger. I kølvandet på desintegrationstendenserne følger mangeartede negative konsekvenser i form af anomireaktioner: selvødelæggelse, (druk, dope, junk og selvmord), eskapisme (konsumfetichisme, ny religiøse bevægelser) individuel og kollektiv kriminalitet osv. Men samtidigt frisættes der altså også modstandsvilje og forandringspotentiale.

Det samfundsmæssigt producerede tab af integrationspotentiale modificeres imidlertid ved en samtidig udvikling og produktion af nye integrationsformer.

Den bevidsthedsindustrielt organiserede ekspropriation af unges selvproducerede sub- og modkulturelle bearbejdnings- og protestformer, og deres omformning til affirmativ konsumkonkurrence i mainstreamkulturen er i denne sammenhæng en ikke uvæsentlig integrationsform.

Det vigtigste - og ikke mindst politisk-strategisk mest centrale er imidlertid den stadigt mere direkte socialstatslige og politistatslige flankering af ikke alene unges, men hele befolkningens livs- og udfoldelsesmuligheder. Udbygningen af et stadigt mere perfektioneret kontrol-, disciplinerings- og overvågningssystem, som er et strukturelt kendetegn ved de højtudviklede kapitalistiske samfund ${ }^{43}$, er ikke mindst i forbindelse med ungdomsprotesten og de nye sociale bevægelser blevet synligt og nærværende.

43. Hirsch. 
Denne udbygning af kontrolapparatet - som mere og mere får »præventiv « karakter, dvs. er i spil før eventuel illegitim adfærd og politisk aktion rent faktisk virkeliggøres - konstituerer konturerne af et nyt legitimationssystem.

I fraværet af en minimalkonsensus i befolkningen omkring samfundssystemets grundværdier bliver det nu de samfundsmæssige, dvs. statslige institutioners funktionalitet og stabilitet, der skal garantere at samfundet ikke falder fra hinanden. Med andre ord: garantien for samfundssystemets bevarelse og videreudvikling på kapitalistiske produktions- og reproduktionsforholds præmisser bliver et spørgsmål om de omsiggribende social- og sikkerhedsapparaters evne til dels præventiv »normalisering « af befolkningen og dels kriminalisering og repressiv udgrænsning af minoriteter. I kølvandet herpå er der udbredte afdemokratiseringstendenser og undertrykkelse af protest- og modstandsmuligheder. Reproduktionen af de kapitalistiske produktions- og reproduktions forhold og gennemsættelsen af værdiloven fordrer i stigende grad (sikkerheds-)statslige reguleringer helt ind i reproduktionssfærens, hverdagslivets og individernes inderste porer. Herved tangeres grundmodsætningen i det kapitalistiske samfund lønarbejde/kapital - af en ny modsætning: stat/folk.

Hermed er der sat en voldsom udfordring for samfundsforandrende kræfter. Den traditionelle venstrefløj må »åbne« op overfor de nye sociale bevægelser, ændre politikopfattelse og politikbegreb. De nye sociale massebevægelser må finde et overgribende forandringsperspektiv - under bevarelse af mangfoldigheden. Forandringens nødvendighed har aldrig tidligere i civilisationens historie været større - såvel »menneskeligt« som økologisk.

44. Brand og Hirsch. 


\section{Litteraturliste.}

Allerbeck, Klaus R.: Ein generationenkonflikt? Der Ertrag der Jugendstudien: Versuch einer Bilanz, i: Jugend, Jugendprobleme, Jugendprotest.

Aust, Stefan \& Sabine Rosenbladt (hrsg): Hausbesetzer. Wofür sie kämpfen, wie sie leben und wie sie leben wollen. Hoffmann \& Campe, Hamburg, 1981.

Bacia, Jürgen \& Klaus-Jürgen Scherer: Passt bloss auf!! Was will die neue Jugendbewegung. Olle \& Woller (Edition Vielfalt), Berlin, 1981.

Baethge, Martin u.a.: Jugend ung Krise - Krise aktueller Jugendforschung. Forschungsberichte des Sociologischen Forschungsinstitut, Göttingen (SOFI). Campus, Frankfurt, New York, 1983.

Bahr, Hans-Eckehard (hrsg): Wissen wofür man lebt. Kindler Verlag München, 1982.

Bay, Joi: Storbyens magikere - om »Birminghamskolens« subkulturteori, i Bidrag nr. 16, 1983.

Behr, Wolfgang: Jugendkrise und Jugendprotest. Kohlhammer, Stuttgart, 1982.

Bjerg, Jens \& Birgitte Elle (red): Ungdom, socialisation og narcissisme. Unge Pædagoger, Kbh. 1982.

Bjфrnshauge, Lars: artikelserie i Blød By nr. 23, 25, 26 og 27: Velkommen til Paranoia City. Kraakstad Amsterdam. Lieber instandbestezen als kaputtbesitzen. Ungdomsbevægelser? 1983-84.

Bopp, Jörg: Angstens magt, i C. Jensen.

Brand, Karl-Werner: Neue soziale Bewegungen: Entstehung, Funktion und Perspektive neuer Protestpotentiale. Ein Zwischenbilanz. Westdeutsher Verlag, Opladen 1982.

Brand, Karl-Werner u.a.: Aufbruch in eine andere Gesellschaft. Neue soziale Bewegungen in der BRD. Campus, Frankfurt 1983.

Brandes, Wolkhard \& Bernhard Schön (hrsg): Wer sind die Instandbesetzer? Päd. extra Verlag. Bernsheim, 1981.

Breyvogel, Wilfried (hrsg): Autonomie und Widerstand. Zur Geschichte des Jugendprotestes. Rigodon Verlag. Essen, 1983.

Brückner, Peter u.a.: Den inre naturens industrialisering. Kapitalism och borgerligt samhälle. i Tekla nr. 12/13, 1982.

Deutsches Jugendinstitut (hrsg): Die neue Jugenddebatte. Was gespielt wird und um was es geht. Schauplätze und Hintergründe. Juventa Verlag, München, 1982.

Dörre, Klaus \& Paul Schäfer: In den Strassen steigt das Fieber. Jugend in der BRD. Pahl-Rugenstein, Köln, 1982.

Eckert, Roland: Das Messen der Aussenwelt an der inneren Sinnvorstellungen. Bewegung der Jugend und organisierte Politik, i Jugend, Jugendprobleme, Jugendprotest.

Fischer, Arthur: Jugend heute: Ergebnisse einer Untersuchung, i Jugend, Jugendprobleme, Jugendprotest.

Gekeler, Wolfram u.a.: Wer nur auf Pflastersteine reagiert, darf sich nicht wundern, wenn - auch Pflastersteine fliegen! Das politische Bewusstsein der neuen Jugendbewegung als Infragestellung der alten »Neuen Linken«, i Brandes \& Schön.

Haller, Michael: Aussteigen oder Rebellieren. Jugendliche gegen Staat und Gesellschaft. Rowohlt, Hamburg, 1981.

Haller, Michael \& Vera Isler: Die Kunst der Verweigerung. Wandmalereien in den Autonomen Jugendzentren der Schweiz. Verlag Pro Juventute, Zurich, 1982.

Hebdige, Dick: Subculture - the meaning of style. London 1979.

Hirsch, Joachim: Der Sicherheitsstaat. Das Modell Deutschland. Seine Krise und die neuen sozialen Bewegungen. EVA, Frankfurt 1980.

Hirsch Joachim \& Roland Roth: Statens krise og de nye sociale bevægelser, i Grus nr. 3, 1981.

Hollstein, Walter: Autonome Lebensformen. Über die transbürgerliche Perspektiven der Jugendbewegung, i Haller, 1981.

Hollstein, Walter: Die Gegengesellschaft. Rowohlt, Hamburg, 1981.

Hollstein, Walter: Die gespaltene Generation. Jugenliche zwischen Aufbruch und Anpassung. Dietz, Bonn, 1983. 
Hornstein, Walter: Unsere Jugend. Über Liebe, Arbeit, Politik. Weinheim \& Beltz. Basel, 1982.

Härlin, Benny: Fra hus til hus, i C. Jensen.

Jugend, Jugendprobleme, Jugendprotest. Kohlhammer Taschenbücher. Stuttgart, 1982.

Jugendwerk der Deutschen Shell: Jugend '81. Lebensentwürfe, Alltagskulturen, Zukunftsbilder. Bd. 1-3. Leske \& Budrich, 1982 Näherungsversuche Jugend 81. Leske \& Budrich. 1983.

Illeris, Knud, Elo Nielsen \& Birgitte Simonsen: Ungdomspsykologi. Samfundssituation, handlemønstre, bevidsthedsformer. Unge Pædagoger. Kbh. 1982.

Jensen, Carsten (red): BZ Europa. Tiderne Skifter, Kbh. 1982.

Kuntz, Karl-Michael: Spontis, Schlaffis \& Chaoten, i Aust \& Rosenbladt.

Lessing, Helmut \& Manfred Liebel: Jeder braucht Jeden. Das Protestpotential geht quer durch alle Schichten, i Brandes \& Schön.

Lindner, Rolf: Kulturanalytiske bemærkninger til den nyere ungdomskrise, i Bjerg \& Elle.

Madsen, Turi Rye, Claus Mellergaard \& Leif Thomsen: Ungdom 80. Ungdom som social bevægelse. Forlaget Politiske Studier, Kbh. 1982.

Müller-Münch, Ingrid u.a.: Bestezung - weil das Wünschen nicht geholfen hat. Rowohlt, Hamburg, 1981.

M $\phi r c h$, Svend: Ungdom og modkultur - om Birminghamskolens bidrag til en ungdomsforskning, i Udkast nr. 2, 1981.

Nielsen, Henrik Kåre: Narcissisme, autonomi og emancipation, i Psyke \& Logos, nr. 1, 1983.

Olsén, Peter \& Birger Steen Nielsen: Unge og arbejdsløshed, i Udkast, nr. 3-4, 1981.

Oltmanns, Reimar: Du hast keine Chance, aber nutze sie. Eine Jugend steigt aus. Rowohlt, Hamburg, 1980.

Parin, Paul \& Thomas Ziehe: Kulturkrise und Revolte, Ethnologische und Kulturtheoretische Beiträge zur Jugendrevolte, i Breyvogel.

Rabehl, Bernd: Im Kampf gegen die Polizei werden sie die Gestalt der Polizei annehmen, i

Bacia \& Scherer.

Richter, Horst Eberhard: Den nye sensibilitet, i C. Jensen

Roth, Roland: Die Indianer sind fern, i Widersprüche nr. 4/5, 1982.

Schäfers, Bernhard: Die Jugendliche ung die Alternativen, i Jugend, Jugendprobleme, Jugendprotest.

Wirth, Hans-Jürgen: Verweigerungswünsche. Über die Jugend als Projektionsleinwand unerfüllter Bedürnisse, i Haller, 1981.

Ziehe, Thomas: Jugendliche sind nicht mehr »jugendlich«, i Bahr.

Ziehe, Thomas: Om narcissismens sårbarhed. Kulturelle frisætningsprocessers psykiske nedslag, i Bjerg \& Elle.

Ziehe, Thomas \& Herbert Stubenrauch: Ny ungdom og usædvanlige læreprocesser. Politisk Revy, Kbh. 1983. 


\title{
Værdiformsanalytisk rekonstruktion af Kapitalen. Del 4
}

\section{Analysen af kapitalens cirkulations- og reproduktionsproces.}

\author{
Michael Eldred, Marnie Hanlon \\ Lucia Kleiber og Mike Roth.
}

\section{Introduktion.}

I denne del præsenteres en værdiformsanalytisk rekonstruktion af Kapitalens 2. bind, som er det mest oversete bind i den marxistiske tradition. Engels' forudsigelse, at »andet bind (vil) vække stor skuffelse, fordi det er så rent videnskabeligt og ikke indeholder meget agitationsmateriale « (Engels til Sorge, 3.6. 1885; B, 296) skulle vise sig at holde stik. Den foreliggende artikel indeholder heller ikke umiddelbart agitationsmateriale. Dette betyder dog ikke, at vi tilstræber et bidrag til en lærd diskussion med $\varnothing$ konomiske professorer. Vi tilstræber at give - tør vi sige det? - dialektisk indsigt i den størrelse, som kaldes kapitalistisk $\varnothing$ konomi, og med denne indsigt - om ikke bevæge bevidstheden - så i det mindste rokke ved den gennem fremstillingen af totalitetens formbestemte modsigelser.

I begyndelsen af Kapitalens 3. bind skriver Marx:

»I deres virkelige bevægelse konfronteres kapitalerne i konkrete former af en sådan art, at kapitalens skikkelse i den umiddelbare produktionsproces og dens skikkelse i cirkulationsprocessen blot fremtræder som særegne momenter. De skikkelser, som kapitalen antager, som vi skal udvikle det i denne bog, nærmer sig altså skridt for skridt den form, hvori de selv optræder på samfundets overflade, i de forskellige kapitalers vekselvirkning i konkurrencen og i produktionsagenternes sædvanlige bevidsthed«. (Rh 3, 36; K3, 33)

Den foreliggende rekonstruktion repræsenterer en bestemt fortolkning af denne passage. De kapitalskikkelser, som Marx refererer til, er handelskapital og bankkapital, som først udvikles af Marx i 3. bind efter cirkulationsanalysen. I modsætning hertil udvikler vi disse »skikkelser « - og giver begrundelse for vores omplacering - i den foreliggende artikel ( $\$ 49 f)$. Vores fortolkning af den »skridtvise tilnærmelse« til »samfundets over- 
flade « fokuserer på i) den voksende mystifikation, som kapitalforholdet og kapitalprocessen undergår gennem de former, som udvikles i cirkulationsanalysen (se især § 47), og ii) partikulariseringen af kapital, som i første omgang udvikles med udviklingen af tre typer fungerende kapital og $\mathrm{i}$ anden omgang med den nødvendige betragtning af varens særegenhed som brugsværdi i relation til den totale reproduktionsproces. Denne fremadskridende mystificering og partikularisering giver det begrebslige grundlag for en formanalytisk betragtning af »de forskellige kapitalers vekselvirkning « og »produktionsagenternes sædvanlige bevidsthed «. Sidstnævnte indebærer først den begrebslige udvikling af de vigtigste kategorier for det $\varnothing$ konomiske livs overflade, nemlig privatejendommen, ejendomsretten og personen.

Læsere, som ønsker at følge denne videre fremstilling henvises til Eldred: Critique of Competitive Freedom and the Bourgeois-Democratic State: Outline of an formanalytic extension of Marx' uncompleted system, publiceret af Kurasje 1984, og Roth, Kleiber, Hanlon og Eldred: La Forma Valore. Progetto di recostruzione del frammento di sistema di Marx, (oversat af E. Agazzi), Manduria 1984.

\section{Kapitalens cirkulationsproces.}

\section{$\$ 35$}

Valoriseringsbevægelsen, som blev udviklet i § 23 og yderligere bestemt i § 26 , tages op igen. Denne gang vil det nu blive taget i betragtning, at denne bevægelse kræver tid. Bortset fra produktionstiden, tiden til den materielle produktion af en vareenhed, er der også cirkulationstiden, dvs. den tid, der er nødvendig til cirkulationshandlingerne: til forvandlingen af penge til varer og varer til penge. I løbet af cirkulationsperioden er varer og penge kapitalens iklædning, nemlig henholdsvis varekapital og pengekapital (til forskel fra rentebærende pengekapital i §§ 24-28). I løbet af produktionsperioden antager kapitalen skikkelse som produktiv kapital, som produktionsmidler. Faserne som produktiv kapital, varekapital, pengekapital, produktiv kapital ... følger som et resultat af hinanden og konstituerer således faserne $i \mathrm{ka}$ pitalens kredsl $\phi b$. De andre produktionselementer, arbejdere og jord, trækkes ind i kapitalens kredsløb som nødvendige komplementære elementer til kapitalens eksistens som produktiv kapital. Lejen af arbejdere og jord og betalingen af $l ø n$ og jordrente er efterfølgende cirkulationshandlinger, som komplementerer de først stedfundne værdiforms-forvandlinger af penge til varer og omvendt. Lånet af pengekapital og dens tilbagebetaling sammen med renten tilhører pengekapitalens fase. 
a) Faserne i kapitalens cirkulation introduceres her udfra produktionens synsvinkel. Cirkulationsprocessen er oprindelig bestemt som umiddelbar udvidelse af begrebet om kapitalistisk vareproduktion. Nedenfor ( $\S 40 \mathrm{ff})$ vil vi se, at begreberne varekapital og pengekapital, dvs. kapitalens eksistens i cirkulationssfæren, ikke er tilstrækkelig godt karakteriseret. I skikkelsen som cirkulationskapital (\$41) antager kapitalens eksistens i cirkulationssfæren en tilsyneladende uafhængig form. Dette udgør på sin side grundlaget for tildelingen af kapitalfunktioner i hver af dens faser til uafhængige kapitaltyper (§ 49): industriel kapital, varehandelskapital og pengehandelskapital.

b) Hele cirkulations- og reproduktionsanalysen, som gennemføres i de følgende paragraffer, er uafhængige af arbejdsværditeorien. Det er i særdeleshed ikke forudsat, som Marx gør det i andet bind, at priserne er proportionale med 'arbejdsværdier'. Gennem hele analysen er det et spørgsmål om at rekonstruere en stringent værdiformsanalytisk argumentationsgang, som kan findes hos Marx, men her sammenblandet med en argumentationsgang, der er baseret på den klassiske arbejdsværditeori (jvf. § 4). I begyndelsen af andet bind skriver Marx:

»For at kunne begribe formerne i deres rene skikkelse er det først og fremmest nødvendigt at abstrahere fra alle de momenter, der intet har at gøre med formskifte og formdannelse som sådan. Det antages derfor her, ikke blot at varerne sælges til deres værdi (hvilket er selvindlysende for en værdiformsanalytisk læsning, EHKR), men også at dette sker under uforandrede omstændigheder. Der bliver således også set bort fra de værdiforandringer, der kan indtræde i løbet af kredsløbsprocessen.« (Rh. 2.1., 38; K2, 32. Jvf. $\S \S 44 \mathrm{f}$ i relation til den anden del af denne forudsætning).

Forudsætningen for fremstillingen, nemlig at »varerne sælges til deres værdi« er - indenfor arbejdsværditeoriens argumentationsgang - vigtig for Marx som en indirekte reference til »transformationen af værdier til produktionspriser« i bind 3. At dette emne er overlæsset med problemer kan ses af den omfattende debat om »transformationsproblemet $\ll^{1}$. Den værdiformsanalytiske kritik af arbejdsværditeorien opløser som en behagelig konsekvens transformationsproblemet, eftersom værdistørrelsen ikke kan bestemmes uafhængigt af værdiformen.

1. Jvf. P. Samuelson, Understanding the marxian notion of exploitation: A summary of the so-called transformation problem between marxian values and competition prices, i: Journal of economic litterature, 9/1971. R. Picard, Wert und Preis in den Marxschen politischen Ökonomie, Erlangen 1974. R. Picard, Zum quantitativen Wertproblem, i: Gesellschaft 3/1975. R. Picard, Gibt es ein Transformationsproblem, i: Gesellschaft 13/1979. D. Foley, The value of money, the value of labour-power and the marxian transformation problem, $\mathrm{i}$ : Review of radical political economi vol. 14, nr. 2, 1982. 


\section{$\S 36$}

Kapitalens tilbagevendende valoriseringsbevægelse indebar kontinuitet i produktionsprocessen så længe vi så bort fra cirkulationsperioden. Denne kontinuitet bliver afbrudt på dette niveau gennem inddragelsen af cirkulationsperioden i analysen. Der kan nu kun skabes kontinuitet i produktionen ved ikke at betragte kapitalens bevægelse som et enkelt valoriseringskredsl $\varnothing b$, men som flere kredsl $\varnothing \mathrm{b}$ med en passende faseforskydning, dvs., det er nødvendigt med en deling af kapitalen. Rækkefølgen af kapitalens faser formidles således af en sammenhæng af kapitalsfarer, hvor dele af kapitalen opholder sig i deres bevægelse fra fase til fase. Det antal kredsløb, som er nødvendige for at formidle kapitalens totale kredsløb med produktionens kontinuitet, afhænger af de enheder i hvilket vareproduktet cirkulerer og af forholdet mellem det enkelte kredsløbs varighed (omslagstiden) og produktionstiden. Produktionstiden defineres som den gennemsnitlige varighed af et vareprodukts ophold i produktionsprocessen. Cirkulationstiden defineres analogt. Produktionstiden og cirkulationstiden taget under ét udgør et kredsløbs varighed, dvs. omslagstiden.

\section{$\S 37$}

Pengekapital-fasen i et kredsløb kan blive forlænget af den omstændighed, at den produktive fase $\mathrm{i}$ et andet kredsløb endnu ikke er afsluttet. Pengekapitalen må således holdes flydende og afvente sin indtræden i den produktive kapitals fase. Derved opstår der en latensperiode for pengekapitalen, hvor varekapitalen allerede er blevet forvandlet til penge, alle betalinger er blevet foretaget med udbyttet deraf og hvor nye produktionsmidler kunne købes, hvis det ikke var for den kendsgerning, at de endnu ikke er nødvendige i produktionsprocessen. Denne latensperiode i pengeform ville kunne ændres til en latensperiode for den produktive kapital, hvis lagre af råmaterialer osv. blev opbygget. Vi kan tale om en latensperiode for (penge eller produktiv) kapital som opstår pga. delingen af kapitalen $(\S 36)$ i en række kredsløb for at skabe kontinuitet i produktionsprocessen. Hvis produktions- og cirkulationsperioderne først defineres uafhængigt af denne latensperiode, dvs. mht. deres længde, når man kun betragter et kapitalkredsløb, og hvis forholdet mellem cirkulationsperioden og produktionsperioden er x, så opstår en latensperiode i den betydning, som er beskrevet her, hvis og kun hvis x ikke er et helt tal. Hvis $x$ er et helt tal, så er antallet af kredsløb givet med $x+1$. Hvis f.eks. $x=2$, så er der tre kapitaldele i tre kredsløb, hvilket kan illustreres som følger: 


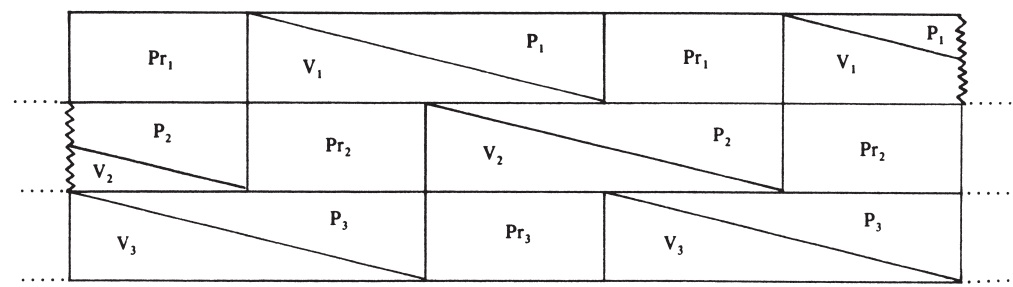

Figur 1

Hvis $\mathrm{x}$ ikke er et helt tal, så er antallet af kredsløb lig med $\overline{\mathrm{x}}+1$, hvor $\overline{\mathrm{x}}$ er det mindste hele tal større end $\mathrm{x}$. Hvis f.eks. $\mathrm{x}=11 / 2$, så er antallet af kredsløb igen lig med 3, og kapitalen ligger latent og afventer sin anvendelse i produktionsprocessen.

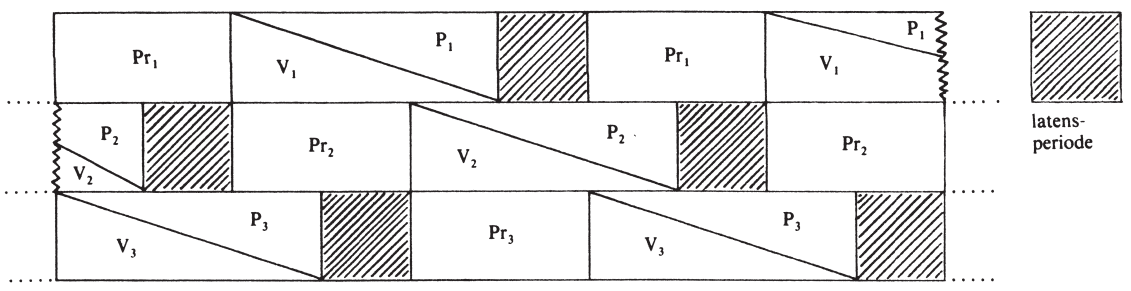

Figur 2

Betydningen af produktionsprocessens kontinuitet vil blive diskuteret i forbindelse med fix-kapitalen (jvf. § 38). Begrænsninger på kapitalens valorisering, som opstår pga. kapitalens eksistens som cirkulationskapital (§ 41) vil blive diskuteret, så snart cirkulationsomkostningerne er blevet introduceret (jvf. $\S \S 42,48$ ).

\section{$\S 38$}

Efter produktionsperioden går hele kapitalen i den produktive fase ikke over i cirkulationsfasen. En del af den produktive kapital, som ikke blev fuldstændigt produktivt konsumeret i produktionsperioden, forbliver i produktionssfæren. Den del af kapitalen, som ikke cirkulerer en bloc med vareproduktet gennem de forskellige kapitalfaser, men kun gradvis, kaldes fix-kapital. Den del af fix-kapitalen som forbliver i produktionssfæren efter en produktionsperiode kaldes hvilende fix-kapital, i modsætning til den del af fix-kapitalen, som cirkulerer med produktet (som gammelværdi, jvf. § 18) og som vi kalder cirkulerende fix-kapital. Den cirkulerende fix-kapital, som er blevet rea- 
liseret i penge, kan ikke umiddelbart indtræde i produktionssfæren igen pga. den ufuldstændige konsumtion af fix-kapitalen. Den forbliver istedet fikseret i pengekapitalfasen som latent kapital og udgør en afskrivningsfond for fixkapital. Svarende til formindskelsen af den hvilende fix-kapital vokser afskrivningsfonden indtil de akkumulerede penge endelig bruges til at erstatte det afskrevne maskineri (eller lignende) i produktionssfæren. Fix-kapitalen komplementeres af den cirkulerende kapital, dvs. den del af kapitalen, som cirkulerer en bloc med vareproduktet. I varekapitalens fase omfatter den cirkulerende kapital gammelværdien af produktionsmidlerne, som er blevet fuldstændig konsumeret i den umiddelbart forudgående produktionsperiode (groft taget rå- og hjælpematerialer) sammen med nyværdien, som er skabt i denne produktionsperiode.

a) Med udviklingen af begrebet om fix-kapital slækkes der på den antagelse, som blev indført i $§ 18$, nemlig at »alle produktionsmidlerne konsumeres i løbet af produktionsprocessen«. Begrebet gammelværdi ( $\$ 18)$, defineret som den værdikomponent af vareproduktet, der dækker udlægget til produktionsmidler, må også modificeres. Arbejdet nedlagt i fix-kapitalen er direkte underlagt værdiformen, når det er købt før det indgår i produktionsprocessen. En yderligere indirekte anerkendelse af dette samme arbejde finder sted hver gang produkter, som er produceret med fix-kapitalen sælges. Salgsprisen er en anerkendelse af arbejde udført med bestemte produktionsmidler, og især med en bestemt fix-kapital. Realiseringen af den cirkulerende fix-kapital i pengeform sker gradvis. På det tidspunkt, hvor fix-kapitalen i produktionsprocessen er blevet konsumeret fuldstændigt, vil der være akkumuleret penge nok i afskrivningsfonden til at erstatte den. Der er ingen måde på hvilken man for hvert omslag præcist kan bestemme andelen af fix-kapitalens gammelværdi i vareprodukternes salgspris. Det er imidlertid almindeligt at fordele gammelværdiens realisering af fix-kapital i pengeform ligeligt over fix-kapitalens totale funktionsperiode (dens 'levetid'). Forskelle mellem ideelle kalkulationer over fix-kapitalens afskrivning og virkelige værdiformsrelationer, der faktisk realiseres, og som en indeholdt i værdiformen selv, vil blive unders $\emptyset \mathrm{gt}$ nedenfor ( $(44)$.

b) Kapitalens latensperiode er et vigtigt tema i den følgende beskrivelse. Man må skelne mellem to former for latensperiode: materiel og pengemæssig latens. Kapitalens materielle latensperiode (brakliggende produktiv kapital) kan formindskes gennem f.eks. kontinuitet i produktionen (således at fix-kapital ikke temporært er brakliggende). En sådan produktionskontinuitet kræver imidlertid en vis grad af latens for den cirkulerende kapital (la- 
gerlagte råmaterialer), som på sin side kan formindskes gennem at foretage indkøb i faser (oftere, men mindre indk $ø$ b). Dette betyder imidlertid blot, at latensperiodens skikkelse delvis er ændret fra materiel til pengeform. Vi har således det paradoksale resultat, at kapitalens valoriseringskredsl $\varnothing \mathrm{b}$ med nødvendighed producerer latent kapital. Specielt betyder dette for penge, at bevægelsen fra penge til flere penge med nødvendighed forudsætter og skaber penge, der ikke umiddelbart deltager i valoriseringsbevægelsen. I $\S$ 46, 48 vil det blive klart, hvorfor enhver latensperiode er en forhindring for kapitalens valorisering. Mens en vis grad af materiel latens (f.eks. usolgte varer) begrænser en individuel kapitals valorisering, så eksisterer derimod den mulighed for latent pengekapital, at den via banksystemet $(\S \S 53,56)$ kan deltage i den samlede samfundsmæssige valorisering.

\section{§39}

Sondringen mellem fix-kapital og cirkulerende kapital rejser kravet om en nuancering af analysen af, hvorledes kontinuiteten i produktionen opretholdes gennem deling af kapitalen. Hvis produktionen ophører for en periode, så er den hvilende fix-kapital (§ 38) tvunget til at ligge brak. For at starte en produktionsproces kræves der en oprindelig kapital til køb af fix-kapital og cirkulerende kapital til den første produktionsperiode (§ 35). Når vareproduktet dukker frem efter denne første produktionsperiode, kræves der en tillagskapital for at holde produktionsprocessen virksom. Denne tillægskapital er mindre end den oprindelige kapital, fordi fix-kapitalen ikke skal erstattes efter en produktionsperiode. Der kan være behov for yderligere tillægskapital afhængig af forholdet mellem cirkulationsperioden og produktionsperioden. Mens vi i $§ 37$ antog, at delingen af kapitalen var en deling i kredsløb af ens størrelse, så kan deres størrelse nu variere. Rækkefølgen af udlæggene kompliceres yderligere, når vi slækker på den antagelse, at kapitalen til en produktionsperiode udlægges på en gang. Cirkulerende kapital, inclusive betaling af lønninger, kan udlægges gradvis i løbet af produktionsprocessen i et antal faser, der afhænger af, hvornår produktionsprocessen fordrer, at særlige midler sættes i sving. Hvis den produktive kapital blev udlagt på en gang, ville det skabe latent kapital i produktiv form. Men som vi bemærkede i $\S 38$ b, er det mere fordelagtigt at have latent kapital i pengeform. Det stykvise udlæg af kapital forstyrrer det simple billede af, at kapitalens deling bestemmes af forholdet mellem produktionsperiode og cirkulationsperiode. I stedet for deles kapital i et antal dele af forskellig størrelse, som må udlægges i en uregelmæssig rækkefølge.

Begrebet oprindelig kapital defineres ikke eksplicit af Marx (jvf. Rh. 2.2, 344; K2, 262). I kapitel 15 »Omslagstidens virkning på kapitaludlæggets 
størrelse« taler han om tillægskapital (Zuschusskapital). Selve kapitlet behandler i detaljer kapitalens deling ( $\$ 36$ ), som nødvendig for kontinuiteten i produktionen under den forudsætning, at hele kapitalen består af cirkulerende kapital (Rh. 2.2, 341; K2, 260). Han gør denne forudsætning, selvom sondringen mellem fix-kapital og cirkulerende kapital indføres i kapitel 8. Vi bruger dette som en begrundelse for at vende rækkefølgen om, i hvilken vi behandler emnerne 'kapitalens deling' (§ 36) og 'fix-kapital' og 'cirkulerende kapital' (§ 38) i forhold til Marx' rækkefølge.

\section{$\S 40$}

Cirkulationssfæren kræver ikke blot tid til, at den valoriserende kapital kan passere igennem den, men den kræver også at lønarbejdere udfører cirkulationsarbejde. Dette arbejde, som er stringent relateret til værdiformens ændring fra penge til vare og omvendt, eller til at etablere eller fastholde lånerelationer uanset type, producerer ingen industrielle varer og er således ikke værdiproducerende, dvs. det er i denne forstand uproduktivt arbejde. Uproduktivt arbejde er ikke desto mindre et nødvendigt tilbehør til produktivt arbejde. Det er arbejde, som altid indebærer omsætning af penge. Lønnen, som betales til cirkulationsarbejderne, er således et fradrag fra merværdien (dvs. det er ikke en del af den nødvendige værdi (§ 14), som er skabt i produktionsprocessen).

Transport og oplagring af varer omfatter aktiviteter, der falder i en særlig gruppe i og med, de formidler produktionen af det materielle produkt med dets endegyldige konsumtion. Samtidig er der ikke tale om aktiviteter, der forvandler værdiformen, dvs. køb eller salg, selvom de er intimt forbundne med forvandlingen af værdiformen, varer bliver f.eks. transporteret til dens køber, eller den usolgte vare bliver oplagret indtil dens salg. Man kan betragte spørgsmålet på følgende måde: produktionen af en vare er ikke fuldendt, før den er solgt. Når en vare er solgt, kan salgsprisen includere transport og oplagring af varen. Dette gælder selv hvis varen stadig skal leveres eller oplagres i en periode af den sælgende kapitalist. Arbejdet, som anerkendes i salgsprisen includerer således transport- og oplagringsarbejde udført af den sælgende kapitalist. Selvom de aktiviteter som omfatter transport og oplagring af det producerede produkt, som nu udbydes til salg på markedet, er produktive aktiviteter, så betragtes de som findende sted i cirkulationsperioden for at undgå en dobbelt opregning af cirkulations- og produktionstiden, hvor de overlapper hinanden. Marx skriver om transport-industrien:

"at den fremtræder som fortsættelse af en produktionsproces inden for cirkulationsprocessen og for cirkulationsprocessen«. (Rh. 2.1, 194; K2, 153). 
Køberen kan enten være en kapitalist eller en individuel forbruger. I det sidste tilfælde falder de yderligere processer, som den solgte vare gennemløber, uden for analysefeltet, som udelukkende beskæftiger sig med produktion og cirkulation af kapital. Transport og oplagring, som udføres af private individer er ikke værdiskabende. Når køberen er en kapitalist, så hører arbejde til transport og oplagring af de købte produktionsmidler, når det udføres af den købende kapitalists lønarbejdere, til den købende kapitalists produktionsproces. Hvis cirkulationsmidler købes ( $(41)$, så er deres transport og oplagring uproduktivt arbejde. Forstået på denne måde er transport og oplagring (vare)produktive aktiviteter som »tilføjer et rum-tid indeks til vareproduktionen, dvs. varer må konsumeres og dette kræver transport og dannelse af varebeholdninger «. (Eldred/Roth, 1978, s.95). Den produktive karakter ved dannelsen af en varebeholdning - i modsætning til tilfældet med transporten (jvf. Rh. 2.1, 190ff; K2, 150ff) - behandles ikke entydigt af Marx. På den ene side adskiller Marx oplagringsomkostninger fra rene cirkulationsomkostninger derved, »at de til en vis grad indgår i varernes værdi, altså fordyrer varen«. (Rh. 2.1, 177; K2, 140). Oplagringsarbejdet er nødvendigt for »bevarelsen af varernes værdi « (Rh. 2.1, 177; K2, 141) gennem opretholdelsen af varens brugsværdi. På den anden side argumenterer Marx for, at oplagringsomkostninger, som er et resultat af »den tid, der medgår til at forvandle eksisterende værdier fra vareform til pengeform, dvs. alene har deres oprindelse i en specifik samfundsmæssig form for den samfundsmæssige produktionsproces « (ibid), udelukkende er uproduktive cirkulationsomkostninger. Få sider senere (Rh. 2.1, 189; K2, 149) dukker samme argument op igen, hvor Marx søger at skelne mellem normal og unormal dannelse af varebeholdninger. Normal beholdningsdannelse er den varebeholdning, som er samfundsmæssig nødvendig, selvom arbejdsprodukterne ikke antager vareform. I modsætning hertil finder en unormal beholdningsdannelse kun sted, når varerne ikke kan sælges, dvs. når en eller anden slags overflod opstår. Efter vores opfattelse er denne sondring usammenhængende, fordi den form-ubestemte kategori »varebeholdningsdannelse « $\mathrm{i}$ samfund $\mathrm{i}$ almindelighed ikke kan specificeres. Vi foretager i stedet for en skelnen mellem rene uproduktive cirkulationsomkostninger og oplagring og transport på grundlag af forvandling af vareform til pengeform og omvendt, således at uproduktive aktiviteter og omkostninger altid omfatter omsætningen af penge. Problemet kan ikke afgøres ved at spørge, hvilke omkostninger, der indgår i varens salgspris. Dette er et fuldstændigt udvendigt, begrebsløst profitskabelsesstandpunkt, som også er gyldigt for handelskapital (§ 49), og det er derfor ubrugeligt overfor det forhåndenværende problem. På samme måde er det umuligt at etablere en kategorial forskel mellem en epokal ka- 
tegori (cirkulationsarbejde) og en forestillet transepokal opfattelse af samfundsmæssigt nødvendigt oplagringsarbejde. Dette sidste er ikke baseret på den dagligdags bevidsthed, og kan ikke udvikles fra denne.

Kontinuiteten i produktionen kræver enten, at kapitalisten har et lager af cirkulerende kapital for hånden, eller at han nemt kan skaffe sig det på markedet. En varebeholdning må derfor eksistere i den ene eller anden form, og arbejdet knyttet til at opbygge og vedligeholde denne varebeholdning anerkendes i prisformen, som en integreret del af vareproduktets produktionsproces. Betragtet fra den sælgende kapitalists standpunkt er et lager af varekapital nødvendigt for at sikre kontinuiteten i cirkulationsfasen, f.eks. at være i stand til at opfylde ordrerne, som strømmer ind fra kunderne, hvadenten det er kapitalister eller andre. Selvom arbejdet med transport og dannelse af varebeholdninger er produktivt, dvs. værdidannende, så er det ligesom alt andet produktivt arbejde underlagt værdiformen, og vil under visse omstændigheder ikke opnå anerkendelse eller en anerkendelse, der er utilstrækkelig til at dække omkostningerne. Transport- og oplagringsarbejde kan være forgæves, hvis vareproduktet på trods af dette arbejde forbliver usolgt. Der kan også opstå en anden situation, hvor to varer, som er blevet transporteret over forskellige afstande eller blevet oplagret i forskellige tidsperioder, sælges til samme pris på trods af disse forskelle. Det yderligere transporteller oplagringsarbejde opnår i dette tilfælde ikke en supplerende værdiformsanerkendelse. Den produktive karakter ved vareoplagring og transport må ses i modsætning til den ikkeproduktive karakter ved oplagringen, transporten og omsætningen af penge, hvilket altsammen hører strikte til cirkulationsarbejdet.

\section{$\S 41$}

Cirkulationssfæren kræver ikke blot cirkulationsarbejde ( $\$ 40)$, men også udlæg af kapital til cirkulationsmidler, dvs. til industrielle varer, som er nødvendige for udførelsen af cirkulationsarbejdet. Disse cirkulationsmidler falder i lighed med produktionsmidlerne i to kategorier: fix-cirkulationskapital (f.eks. varehuse, computere), som fungerer i adskillige omslagsperioder for cirkulationskapitalens individuelle kredsløb; og cirkulerende cirkulationskapital (f.eks. kontormaterialer, lys), som konsumeres i løbet af en vareenheds vej gennem cirkulationssfæren. Som en konsekvens af diskontinuiteten i produktionskapitalens eksistens i cirkulationssfæren (§ 37) må cirkulations-kapitalen og især fix-cirkulationskapitalen med mellemrum ligge brak i materiel form (f.eks. uudnyttet kapacitet i varehusene, uudnyttet computerkapacitet, underbeskæftigede kontorarbejdere). Analogt til cirkulationsarbejdet er den cirkulationskapital uproduktiv, som egentlig ikke cirkulerer 
i et værdikredsløb, fordi den udlagte værdi konsumeres i cirkulationssfæren uden at forøge værdidannelsen. Cirkulationskapitalen genvindes kun som en bestanddel af vareproduktets merværdi. I modsætning til produktionskapitalen, som udlægges i produktionssfæren og som passerer igennem cirkulationssfæren i dens valoriseringsbevægelse, opsuges cirkulationskapitalens værdi af cirkulationssfæren uden at efterlade sig et spor.

Der er her tale om en dobbelt brug af terminologi. Cirkulationsmidler, som de er defineret her, må ikke forveksles med penge som cirkulationsmidler (§ 9).

\section{$\S 42$}

Med cirkulationskapitalen er begrebet om omkostninger ( $\$ 23)$ udvidet til at omfatte udlægget til cirkulationsmidler og betaling for cirkulationsarbejde, for jordrenten på den jord, som anvendes til cirkulationsaktiviteterne såvel som til renten af den lånte cirkulationskapital. I tillæg til de produktive kapitalomkostninger må alle disse omkostninger fradrages fra vareproduktets værdi som cirkulationsomkostninger, hvilket efterlader en reduceret overskydende virksomhedsprofit. Dette udvidede omkostningsbegreb mystificerer yderligere valoriseringen af kapitalen gennem udbytning af arbejdskraft ved også at includere kapital, som ikke har nogen egentlig cirkulær bevægelse og arbejde som ikke skaber værdi. Et yderligere trin i udvendiggørelsen af kapitalens bevægelse fra værdidannelsesprocessen og et yderligere trin i den deraf følgende mystifikation af værdidannelsesprocessen opstår i og med, at kapital ikke blot udlægges til køb af produktions- og cirkulationsmidler, men også til betaling af lønninger, jordrente og rente, dvs. til betaling af revenuer. Dette sker i tilfælde, hvor den fastsatte dato for betalingen af revenuerne indtræder før den udlagte kapital vender tilbage fra salget af produktet og således muliggør, at betalingerne kan ske ud af indtægterne. Adskillelsen mellem betaling og udlæg bliver udvisket. Kapitalens kredsløbslignende bevægelse opløses i et virvar af betalinger og indtægter på alle mulige tidspunkter. Omkostninger, som er pådraget på et tidspunkt, dækkes gennem indtægter på et senere tidspunkt. Kapitalkredsløbenes valoriseringsbevægelse udvendiggøres i en mængde omkostningskredsl $\varnothing b$, som periodisk udlignes gennem indtægter. Denne udvendiggørelse af kapitalbegrebet begyndte allerede med bestemmelsen af valoriseringen som salgsprisens overskud i forhold til omkostningerne (§ 23). Nu er der imidlertid selv dele af merværdien, nemlig udlæggene til revenu og cirkulationskapital, som er blevet kapitaludlæg og således tilsyneladende valoriserende kapital. Begrebet om omslag (§ 36) er således 
modificeret (og udvendiggjort) til at omfatte perioden mellem udlægget og tilbagekomsten af dele af kapitalens omkostninger. Eftersom omkostningskredsløbet ikke nødvendigvis svarer til den valoriserende værdis kredsløb, er omslaget defineret som tiden mellem udlægget og tilbagekomsten af indtægterne fra det produkt, som den (i tilfældet med cirkulationskapitalen) hjælper med at cirkulere, eller af hvilket den (i tilfældet med produktionskapitalen) udgør en værdibestanddel. Omslaget for udlægget til revenuomkostninger bestemmes af tiden fra udlægget af kapital til tilbagekomsten af indtægterne fra det produkt, hvis produktion og cirkulation medførte omkostningerne, som blev udlagt. Hvis færre omkostninger beregnes dækket af indtægterne, så er virksomhedsprofitten større, men omslagstiden for den udlagte kapital er dermed blevet tilsvarende længere.

Omslagsbegrebet er nu kompliceret af mængden af udlæg, der foretages, og af udlæggets art (til produktionskapital eller til betaling af revenu). Omslagsperioden, for den totale fungerende kapital (oprindelig og tillægskapital) (§ 43) som anvendes, bestemmes ved at integrere omslagstiden for hvert enkelt udlæg og sammenvejning af hver af disse omslagstider i forhold til udlæggets størrelse. Dette giver begrebet aggregeret omslagstid.

\section{$\S 43$}

Begreberne oprindelig kapital og tillaggskapital (§ 39) er nu udvidet til ikke kun at dække produktionskapital, men også cirkulationskapital og udlæg foretaget til revenubetalinger. I stedet for at være et antal af den valoriserende værdis kredsløb bliver kapitalens bevægelse dermed en mængde udlæg til forskellige omkostninger og generhvervelsen af disse omkostninger plus en virksomhedsprofit. Salget af vareproduktet vedbliver at være det punkt fra hvilket indtægterne flyder til kapitalisterne. Den oprindelige kapital vedbliver at være den fixe og cirkulerende produktionskapital, som er nødvendig for at sætte produktionsprocessen i bevægelse. Tillægskapital er nødvendig 1) for at erstatte den cirkulerende produktionskapital efter at den har bevæget sig ind i cirkulationssfæren, 2) som (fix og cirkulerende) cirkulationskapital, 3) til betaling af revenuer (når den fastsatte betalingsdato falder før tilstrækkelige indtægter er akkumuleret fra salg af produktet), 4) til tilbagebetaling af lånekapitalen (når tilbagebetalingsdatoen falder før kapitalen er vendt tilbage gennem indtægter fra salget), og 5) til erstatning af den fixe kapital in natura efter den sidste bestanddel af den fixe (produktions eller cirkulations) kapital er blevet konsumeret, således at kontinuiteten i produktions-og cirkulationsarbejdet kan opretholdes, selvom omkostningerne til den sidste bestanddel af fix-kapitalen endnu ikke er blevet dækket 
ind af kapitalens cirkulære bevægelse. Summen af den oprindelige kapital plus alle tillægskapitalerne bestemmer størrelsen af den valoriserende kapital, eller den fungerende kapital. Sondringen mellem oprindelig kapital og tillægskapital gør det klart, hvilke yderligere omkostninger en ny kapital må regne med, hvis valoriseringen af den i første omgang udlagte kapital skal gennemføres. Tillægsomkostningerne kræver på den anden side yderligere udlæg, hvilket gør kapitalens valoriseringsproces til en vedvarende proces, som i sig selv ikke har nogen slutning.

\section{$\S 44$}

Begrebet omslag ( $§ 42)$ opstår i forbindelse med en vedvarende kapitalvaloriseringsproces i hvilken fungerende kapital anvendes igen og igen i gentagne kredsløb med udlæg og dækning af omkostninger. I denne cirkulære bevægelse i tiden kan værdiformsanerkendelsen af det vareproducerende arbejde i penge såvel som priserne for de andre produktionselementer ændres. Kapitaludlægget til produktionsmidler generhverves som en del af produktværdien som gammelværdi ( $§ 18$ ). Den oprindelige udlagte værdistørrelse kan meget vel være forskellig fra den aktuelle genanskaffelsespris for produktionsmidlerne, som må dækkes af produktværdien, hvis et nyt kredsløb skal kunne påbegyndes. I løbet af den tid, som det tog den udlagte produktionskapital at slå om, kan priserne for disse produktionsmidler være steget eller faldet. Fungerende kapital er således enten frisat fra kredsløbet - i tilfælde af prisfald - eller der er brug for tillægskapital til at financiere de forøgede omkostninger til produktionsmidler. Vi forudsætter her at enhver tillægskapital, som er nødvendig, hidrører fra salgsindtægterne af produkterne fra det foregående kredsløb. Gammelværdien, som nu defineres som den værdibestanddel af produktet, som er lig med den aktuelle genanskaffelsespris for produktionsmidlerne (jvf. § 18b), kan derfor adskille sig fra den kapitalværdi, som oprindeligt blev udlagt til produktionsmidler. Kapitalens omslag kan ikke begribes som en proces i hvilken værdien automatisk bevarer og forøger sig selv, men som en proces i hvilken vedligeholdelsen af værdien over tiden drages i tvivl gennem tilfældigheden i vareudvekslingsprocessen. Målet at forøge værdien kan blive fuldstændig forpurret, hvis det ikke lykkes en udlagt værdi at vedligeholde sig selv henover dens omslag. Problemet med den udlagte produktionskapital-værdis afvigelse fra gammelværdien i løbet af omslaget er så meget desto mere markant for den fixe produktionskapital hvor omslagsperioden er længere. Den udlagte fix-kapital slår gradvis om i løbet af hvert af den cirkulerende kapitals kredsløb. Omfanget af dette gradvise omslag kan ikke fastsættes præcist, og må således baseres på en kalkulation, i hvilken det gradvis stigende omslag antages at foregå ensartet henover den formodede 
levetid for den fixe kapital. Alle disse kalkulationer viser sig at være nytteløse, hvis prisen for de fixe kapitalproduktionsmidler i mellemtiden ændrer sig, eller hvis den passende fix-kapital, som må genanskaffes, afviger markant fra den fix-kapital, som netop er konsumeret. Den kontinuerte omvæltning af produktionsmetoderne, og den følgende ændring i værdirelationerne, gør sig specielt stærkt gældende for den fixe kapital, hvor dens fixering af kapitalen i materiel form forhindrer dens opdatering.

\section{$\S 45$}

I analysen af den kapitalistiske produktion ( $\S 14 \mathrm{ff})$ blev der afdækket en systematisk grund til, at priserne på produktionsmidlerne ikke forblev konstant, nemlig forøgelsen i produktiviteten i forbindelse med den relative merværdiproduktion. Dette medfører, at de produktionsmidler, som skal genanskaffes til et nyt kapitalkredsløb (og dette er specielt tilfældet med den fixe kapital), ændrer sig 1) i sammensætning og 2) i pris. Ændring i sammensætningen af de produktionsmidler, som er nødvendige (til en mere produktiv produktionsproces), medfører, at den gammelværdi, som skal udvindes af produktværdien for det næste kredsløb, ændrer sig. Det er her ikke længere et spørgsmål om prisændringer på produktionsmidler af samme slags, men om ændringer i selve produktionsmidlerne - og følgelig en ændring i mængden af produktiv kapital, som er nødvendig. Et yderligere problem opstår, når en forøgelse i produktiviteten truer bevarelsen af værdien, som er udlagt til produktionsmidler. Forøgelser i produktiviteten fører generelt til et fald i enhedsprisen på den producerede vare. Hvis en kapital opererer med gammeldags produktionsmidler - i særdeleshed med forældet fix-kapital - så vil dens enhedsomkostninger være højere end for en kapital, der arbejder med nyere og mere produktive produktionsmidler. Hvis den nye produktionsmetode er blevet almindelig og har ført til et fald i enhedsprisen på vareproduktet, så trues omslaget på de forældede produktionsmidler (specielt fix-kapital). Enhedsomkostningerne er for høje til at blive dækket ind af den reducerede salgspris pr. styk. Kapitalen hører op med at valorisere og tillægskapital må fremskaffes fra eksterne kilder for at financiere en ændring i protuktionsmetoden. Den gamle fixkapital må afskrives, som uproduktiv, da den ikke bidrager til skabelsen af virksomhedsprofit under de ændrede værdiformsrelationer og dens omslag bliver brat afskåret. På den anden side er eksistensen af fix-kapital i produktionsprocessen en hindring for indføring af nye, mere produktive produktionsmetoder, som kræver nyt maskineri. En kapitalist vil først anvende en ny produktionsmetode, når hans fixkapital er slået om og således akkumuleret i en afskrivningsfond, der er tilstrækkelig til at dække det nye udlæg til fix- 
kapital. Kun hvis enhedsprisen på produktet er blevet væsentligt reduceret, vil kapitalisten blive tvunget til at afskaffe sin fix-kapital. Anvendelsen af en ny produktionsmetode, som involverer ny fix-kapital, tenderer således mod at finde sted i bølger, som svarer til omslaget for den fixe kapital. Det lykkes for nogle kapitaler først at anvende ny fix-kapital, efter at den gamle er slået succesfyldt om. Andre kapitaler, som ligger bagefter i den fixe kapitals omslag, må enten ophøre med at operere eller afskrive gammel fix-kapital, selvom det endnu ikke er nedslidt.

a) En tilsvarende argumentationslinie kan udvikles for ændringer i priserne på cirkulationsmidler og specielt for omslaget af den fixe cirkulationskapital. Forskellen er, at man ikke har noget begreb om gammel-værdi, som måler succes eller fiasko i bevarelsen af værdien i løbet af omslaget for en udlagt kapital.

b) Kozo Uno har følgende kommentar til de forhindringer for væksten i produktiviteten, som ligger i den fixe kapital:

»Fordi fix kapital udstyr, når man først har investeret i det, må bruges over et spån på adskillige år, så kan en ny produktionsmetode i mellemtiden ikke let fortrænge den gamle metode, som er indeholdt deri ... Den generelle anvendelse af nye produktive metoder må derfor i princippet påtvinges kapitalen af konkurrencens alvor, som den står overfor i faser med industriel krise. « (Kozo Uno, Principles of political economy: Theory of a purely capitalist society, Harvester, Sussex 1980, s. 53.)

Henvisningen til konkurrencen hér er et fingerpeg om, at på dette trin $\mathrm{i}$ fremstillingen er der strengt taget tale om en foregribelse, hvis man taler om erstatningen af fix-kapital under konkurrencens tvang. En nærmere unders $\varnothing$ gelse af den konkurrencesatte subjektivitet og af konkurrencebetingelserne kan findes hos Eldred, 1984, del II og III.

\section{$\S 46$}

Kapitalens valoriseringsproces fremstiller sig som en række af udlæg og afkast. Den kvantitative bestemmelse af denne bevægelse kræver, at yderligere ét moment tages i betragtning: tiden.

Overskuddet (virksomhedsprofitten) er ikke længere forskellen i én enkelt bevægelse P-P', men realiseres kontinuert gennem indtægten fra salget af vareproduktet. Den kvantitative bestemmelse af overskuddet er kun mulig, når en bestemt tidsperiode forudsættes. Traditionelt anvendes en tidsperiode på ét år til sådanne kalkulationer. Overskuddet pr. år sættes i relation til den fungerende kapital $(\S 43)$. 
Begreberne oprindelig kapital og tillægskapital modificeres igen m.h.p. at tage hensyn til tidsenheden på ét år.

Oprindelig årlig kapital betegner den kapital, som i begyndelsen af regnskabsåret (hvor produktionsprocessen allerede kan være i gang) forefindes enten i materiel skikkelse som fix eller cirkulerende kapital eller som pengesummer i kapitalisternes hænder. Årlig tillaegskapital er den tillægskapital, som i løbet af året er nødvendig for at fastholde valoriseringens kontinuitet eller til at udvide valoriseringsprocessen. I den kvantitative bestemmelse af den fungerende kapital anvendes også ét år som kalkulationsperiode, hvor så de forskellige udlæg vægtes svarende til den tid, de befinder sig i produktions-og/eller cirkulationssfæren, dvs. svarende til længden af deres omslagstid (§ 42).

Den årlige fungerende kapital er den gennemsnitlige kapitalstørrelse, som udlægges eller som er ledig i kapitalistens hænder i cirkulations- og produktionssfæren. Eftersom vi antager, at al pengekapital er udlånt, svarer den fungerende kapital til den gennemsnitlige kapitalstørrelse, som er udlånt gennem året. Den årlige virksomhedsprofit er den totale årlige indtægt fra salget af vareproduktet fratrukket de totale årlige omkostninger (hidrørende fra årets $\mathrm{k} \emptyset \mathrm{b}$ af produktions- og cirkulationsmidler samt fra årets betalinger af revenuer). Den årlige nettoprofitrate er forholdet mellem den årlige virksomhedsprofit og den årlige fungerende kapital. Hvis der i løbet af året er foretaget betydelige udlæg af fix-kapital (produktions- eller cirkulationskapital), vil den årlige virksomhedsprofit blive negativ. Af kalkulationshensyn afskrives den fixe kapital over en årrække, i hvilken den fungerer i cirkulations- eller produktionssfæren. De fixe kapitalomkostninger bliver da fordelt over en årrække.

Marx foretager en tilsvarende distinktion mellem fungerende kapital og anvendt kapital i bd. II, kap. 16. Eftersom en årlig fungerende, cirkulerende kapital kan slå om adskillige gange på et år, kan den afvige fra den totale anvendte kapital i løbet af året. Jo hurtigere kapitalomslag, jo mere merværdi produceres pr. år af en fungerende kapital af en given størrelse. Marx' diskussion centrerer sig om »den variable kapital«, som er udlagt til køb af arbejdskraft, eftersom han af arbejdsprocessens elementer isolerer det levende arbejds som merværdiens kilde. Dette gør tillige forudsætningen om en konstant merværdirate plausibel, eftersom konstansen blot kræver faste lønninger (i henhold til arbejdsværditeorien). Vores rekonstruktion af begrebet om relativ merværdiproduktion skulle gøre det klart, at det - for det udviklede begreb om relativ merværdiproduktion (§ 20) - ikke er meningsfuldt fortsat at betragte arbejdskraften isoleret fra de objektive produktionsfakto- 
rer, hvorfor endvidere forudsætningen om en ensartet merværdirate ej heller kan forsvares, så snart begrebet om relativ merværdiproduktion er udviklet.

Ikke desto mindre holder følgende resultat: Alt andet lige er den virksomhedsprofit, som afkastes af en fungerende kapital af en given størrelse, omvendt proportional med dens omslagstid. En kortere omslagstid muliggør en accellereret valorisering.

\section{$\S 47$}

Med begreberne årlig virksomhedsprofit og årlig nettoprofitrate (§ 46) er kapitalens bevægelse som en proces blevet totalt mystificeret. Ikke alene er de totale omkostninger blevet samlet under én hat, hvorved distinktionen mellem de forskellige produktions- og cirkulationselementer er forsvundet; men også kapitalens egen cirkulære bevægelse, værdiens fremadskriden gennem dens forskellige stadier som kapital, er tilsløret. På dette sted korresponderer kapitalbegrebet med dét, som optræder i kapitalistisk bogholderi, dvs. med en aldeles formel, udvendig definition af kapital, i hvilken alle indre forbindelser er blevet udslettet. Især er relationen kapital - lønarbejde og dens iboende værdiskabende funktion i valoriseringen af værdi blevet skjult i mangfoldigheden af omkostninger.

Kapitalrelationens fetischisme viser sig på dette sted i fremstillingen som en mangfoldighed af faktorer, som må tages i betragtning ved bedømmelsen af en given kapitals valoriseringseffektivitet.

Eftersom den indre forbindelse mellem disse faktorer - konstitueret gennem værdikategorierne - forsvinder i kapitalistens omkostnings- og profitkalkulationer, da tillægges de alle samme betydning. Til den praktiske aktivitet $\mathrm{i}$ virksomheden behøves ingen indsigt $\mathrm{i}$ indre begrebslige relationer.

\section{$\S 48$}

Den årlige nettoprofitrate er bestemt af to størrelser: i) årlig virksomhedsprofit og ii) årlig fungerende kapital.

Ad i): Den årlige virksomhedsprofit afhænger af forskellen mellem produktets salgspris og de totale omkostninger. Er salgsprisen pr. enhed fast (markedspris), kan den årlige virksomhedsprofit øges gennem sænkning af omkostningerne (mere favorable indkøbspriser, rente og løn, større produktivitet, større effektivitet i cirkulationsarbejdet, fuld udnyttelse af produktions- og cirkulationskapaciteten) og gennem hurtigere omslag, dvs. gennem en kortere produktions- og/eller cirkulationstid, så den samme kapital kan slå om flere gange på et år. Dette gælder både produktions- og cirkulationskapital. 
Ad ii): Den årlige fungerende kapital kan reduceres ved at sænke omkostningerne og ved at $\varnothing$ ge omslagshastigheden. Tilsvarende kan en fungerende kapital af en given størrelse anvendes til at frembringe flere produkter og større virksomhedsprofit, såfremt enhedsomkostningerne og/eller omslagstiden mindskes.

De forskellige metoder til at reducere den årlige fungerende kapital (i.f.t. et givent produktionsomfang) eller $\emptyset$ ge den årlige virksomhedsprofit kan komme i konflikt med hinanden. F.eks. kan virkningen af en stigning i produktiviteten, som indebærer en forøgelse af produktionens omfang, blive ophævet af en forøgelse i cirkulationstiden (såfremt nye markeder ikke kan findes til merproduktionen).

\section{$\S 49$}

Som vist i den foregående paragraf afhænger valoriseringen af kapital af omkostningerne og produktionens og cirkulationens hastighed. Kapitalens valoriseringsproces formidles af en række autonome kapitalskikkelser, hvilket nu skal undersøges. Dét, som vi hidtil blot har betegnet kapital, skal fra dette punkt i vores fremstilling betegnes grundkapital. Kapital, som anvendes til vareproduktion, betegnes industriel kapital, medens kapital, som anvendes til udførelsen af cirkulationsarbejde, betegnes kommerciel kapital (eller handelskapital).

Da cirkulationssfæren omfatter både varekapitalens og pengekapitalens aktivitetssfærer (§ 35f), kan kommerciel kapital yderligere opdeles i varehandelskapital (købmandskapital) og pengehandels-kapital.

Industriel kapital er hovedsagelig anlagt i produktionssfæren, men omfatter også begge stadier i cirkulationen - omend i forkortet form.

De to stadier i cirkulationen konstituerer aktivitetssfæren for de to typer af kommerciel kapital. Eftersom industriel kapital omfatter alle stadier, så er det dén af de tre kapitaltyper, hvis kredsløb mest ligner grundkapitalens kredsløb.

Varehandelskapital, der ligesom enhver anden kapital er indeholdt i den abstrakte formel P-P', er hovedsagelig anlagt i varekapitalens sfære, men med køb og salg træder den også ind i pengekapitalens sfære. Pengehandelskapitalen er væsentligst begrænset til pengekapitalens sfære og formidler sammenfletningen af industriel kapital og varehandelskapital ved at udføre deres monetære transaktioner. Betalingen af revenu, oplagringen af ledige penge samt administrationen af pengekapitalens udlån (se diskussionen af banker nedenfor $§ \S 51 \mathrm{ff}$ ) udføres også af pengehandelskapital. Opsplitningen af grundkapitalen og formidlingen af dens bevægelse v.h.a. tre gensidigt autonome, men indbyrdes afhængige partielle bevægelser medfører - på grund af denne specialisering - en forøgelse af omslagshastigheden (for de betragtede varer), 
en sænkning af omkostningerne, og - især -en reduktion af ledig cirkulationskapital. Reduktionen fremkommer, fordi kommerciel kapital formidler såvel varesalg som monetære transaktioner for mere end én industriel kapital.

Marx skelner ikke begrebsligt mellem »kapitalens grundform« (Rh. 1, 267; K1, 178) og industriel kapital, men behandler dem synonymt. Han udvikler de afledede kapitalformer i kapitlerne om kommerciel kapital i 3. bind, 4. afsnit efter behandlingen af gennemsnitsprofitraten og dens angivelige tendens til fald. Gennemsnitsprofitraten er imidlertid uden tvivl et tema for konkurrenceanalysen (se Eldred 1984, § 31), eftersom konkurrence mellem kapitaler må introduceres for at forklare tendensen til nivellering af den årlige nettoprofitrate. De tre specialiserede kapitaltypers formidling af grundkapitalens bevægelse er derimod et tema, som falder ind under behandlingen af kapitalens cirkulationsproces. De tre kvalitativt forskellige kapitaltyper opstår organisk ud af betragtningen af de forskellige kapitalstadier, dvs. uafhængig af enhver undersøgelse af profitratens kvantitative bestemthed.

\section{$\S 50$}

Industriel kapital, varehandelskapital og pengehandelskapital er det samme for så vidt det med disse, som med grundkapital, drejer sig om valorisering af udlagte penge. Bestemmelserne af grundkapitalens valorisering kan med passende modifikationer overføres til de nævnte kapitaltyper. De tre typer af fungerende kapital formidler grundkapitalens valoriseringsproces og tager del i den gennem valoriseringen af hver udlagt kapital. Varehandelskapitalens tagen del fremkommer i prisdannelsen mellem industriel kapital og varehandelskapital. Varehandelskapitalens profit er forskellen mellem varernes købspris og salgspris fratrukket cirkulationsomkostninger.

Denne afvigelse mellem købspris og salgspris, som fremkommer gennem tillæg af en profitmargin til købsprisen, bekræfter den naive bevidstheds falske forståelse, at vareprisen simpelthen er summen af omkostningerne med tillæg af en mark-up. Rent faktisk udtrykker varens mellemliggende salgspris ikke varens værdi, men omkostningerne samt den sælgende industrielle kapitals profit. Realiseringen af vareværdien sker først i den endelige (detail-) pris. De mellemliggende priser er blot krav på en del af den endelige realiserede vareværdi. For den sælgende industrielle kapitals vedkommende bliver disse krav umiddelbart tilfredsstillet mod afståelse af en del af den forventede profit, mens det for den kommercielle kapital gælder, at disse krav -som omkostninger - først realiseres i det endelige salg. På dette fremstillingsniveau fremstår den industrielle 
profit som kapitalomkostninger, som endnu ikke er realiseret. Den vertikale opsplitning af grundkapitalen indebærer en vertikal strukturering af varemarkedet, hvilket ikke kun gør kapitalbegrebet, men også prisbegrebet mere overfladisk.

Med distinktionen mellem industriel kapital, varehandelskapital og pengehandelskapital bliver kapitalens saregenhed (partikularitet) for første gang emne i fremstillingen. Denne sœregenhed beror ikke på den producerede vares materielle særegenhed, som først får betydning senere i fremstillingen (se $\S \S 57 \mathrm{ff}$ ). Det er derfor stadig muligt at overføre alle begrebslige bestemmelser, som er fremkommet i udviklingen af det almene kapitalbegreb (som i sidste ende førte til et overfladisk kapitalbegreb), til de tre ovennævnte kapitaltyper. Samtidig indeholder denne differentiering af grundkapital imidlertid et vigtigt moment, som vil lede fremstillingen videre. Dette moment er referencen til kapitalkredsløbets samfundsmæssige sammenhæng. Hidtil er kapitalen og dens valorisering blevet behandlet som noget enkeltstående og autonomt. Denne undertrykkelse af kapitalens samfundsmæssige aspekt hidrører fra værdibegrebet selv, idet netop dette begreb abstraherer fra særegenheden (se § 4) og således fra den rolle, dette moment spiller i den samfundsmæssige reproduktionsproces. Materiel reproduktion er hidtil blevet taget for givet. Denne forudsætning vil blive ophævet i den videre fremstilling ( $\S \S 57 \mathrm{ff}$ ), og dette kræver, at kapitalernes særegenhed bliver taget i betragtning.

På dette sted skal mindes om, at vi begyndte med de mange vareproducenter og deres enshed i kapitalbegrebet. Med absolut og relativ merværdiproduktion opstod differentieringer, som satte deres præg på produktionsprocessens konkrete skikkelse. Varens særegenhed forblev imidlertid uden betydning. Vareproducenten blev individualiseret som de mange kapitaler i en branche. Denne individualisering gjaldt alle vareproducenter og var derfor en almen bestemmelse. På samme måde gælder alle foranstående bestemmelser af kapital for alle individuelle kapitaler i en branche. Kapitalbegrebet bliver dermed udviklet, men forbliver alment, da de yderligere bestemmelser ikke beror på varens særegenhed. De videre bestemmelser af kapitalbegrebet berører således ikke dets almene gyldighed, men adskiller sig ikke desto mindre fra den tidligere begrebslige udvikling. Dette hænger sammen med, at kapitaler ikke længere undersøges som om de var autonome, men i stedet bliver den indbyrdes afhængighed mellem de tre kapitaltyper, som formidler grundkapitalens kredsl øb, bragt i forgrunden. Hvad angår kommerciel kapital er denne formidling ikke begrænset til en individuel grundkapital, men omfatter flere. Med begrebet kommerciel kapital (som omfatter både købmandsog bankkapital) bliver grundkapitalerne, som her optræder i forkortet form som industrielle kapitaler, bundet til hinanden i deres kredsløb. Fremfor alt 
er det banksystemets almenhed ( $\S 51 \mathrm{ff})$ og dets almene vare, lånekapital, som understreger de individuelle kapitalers indbyrdes afhængighed, eftersom banksystemet fungerer som akkumulationsstedet for pengekapital, som siden stilles til rådighed for de talrige individuelle fungerende kapitaler.

\section{$\S 51$}

Pengehandelskapitalen udfører de forfaldne betalinger, opbevarer ledig kapital og administrerer lånerelationer for de fungerende kapitaler. For disse funktioner modtager den virksomhedsprofit. Administrationen af lånerelationer skal nu undersøges nærmere.

Opbevaringen af store mængder ledig pengekapital tilhørende de fungerende kapitaler og andre indskydere, gør det muligt for pengehandelskapitalisten at udlåne disse indskud til trediepersoner som rentebærende kapital uden at forstyrre de indskydende fungerende kapitalers valoriseringsproces. Vi har tidligere set (§38), at ledig pengekapital er et nødvendigt biprodukt til valoriseringsprocessen, især som ledig fix-pengekapital, som gradvist akkumuleres i en afskrivningsfond. En anden kilde til ledig pengekapital er den akkumulerede virksomhedsprofit, som den fungerende kapitalist i sidste instans kan anvende til at ekspandere produktionens omfang. Ved at udlåne pengekapital fremstår pengehandelskapitalen for udenforstående som rentebærende pengekapital og bliver derigennem i systematisk forstand en bank. Den rente, som banken modtager for udlånte penge, deles mellem banken og indskyderne (som ikke nødvendigvis kun behøver at være fungerende kapitalister). Eftersom det i en vis udstrækning er umuligt at afgøre hvis penge, som er genudlånt, opnår enhver indskyder rente af indskuddet. Ledig kapital, som koster den lånende fungerende kapitalist en rente, bliver som indskud rentebærende for den indskydende fungerende kapitalist. Differencen mellem den rente, som banken modtager for udlån og rente, som banken betaler indskyderne, konstituerer størsteparten af bankens virksomhedsprofit og bestemmer derigennem valoriseringen af bankens fungerende kapital. Der må skelnes skarpt mellem denne fungerende kapital og den i banken indskudte kapital. Bankens fungerende kapital består af fixe kapitalomkostninger (bankbygning, computer, bokse, alarmsystemer etc.) og cirkulerende kapital (papir, formularer og, især, løn til bankpersonalet). Udover jordrente og rente af lånt fungerende kapital er det især renteudbetalinger på indskud, der fremstår som omkostninger. Rentebetalinger på indskud kan sammenlignes med de priser, som en varehandelskapital må betale for varer (som fremstår som cirkulerende kapitalomkostninger for varehandelskapitalen). Forskellen er, at den vare, som banken handler med, er pengenes egenskab i henseende til at blive udlagt som kapital (§ 24). Banken køber denne egenskab billigt og sælger den dyrere. 
Eftersom banken er en fungerende kapitalist (med pengekapitalistens maske), der i lighed med alle fungerende kapitalister arbejder med lånte penge (denne forudsætning vil blive slækket i konkurrenceanalysen), opstår spørgsmålet hvorfra banken låner dens fungerende pengekapital. I princippet kan den låne af sig selv, ud af de indskudte penge. (Endvidere kan den skabe sin egen fungerende pengekapital; se $\S 56$ ). Distinktionen mellem indskudte penge og fungerende kapital svarer til bankens dobbelte bestemmelse som udlånende pengekapitalist og pengehandelskapitalist. Denne fordobling af banken er fordelagtig, eftersom banken selv sparer forskellen mellem renten på bankkredit (§ 53) og renten på indskud. Uanset denne fordel må banken sikre, at den er i stand til at tilbagebetale indskud svarende til de betingelser, under hvilke de blev indskudt.

\section{$\S 52$}

Enhver indskyder ( $\$ 51)$ har en bankkonto, som har en bestemt (for det meste rentebærende) saldo. Disse saldi repræsenterer giropenge, som skal skelnes fra den eneste type penge ( $\$ 9 \mathrm{a}$ ), som er udviklet hidtil, nemlig guldpenge ( $\S 6 f f)$. Guldpenge besidder de bestemmelser, som fremkom i analysen af penge og varer (§ 9), nemlig cirkulationsmiddel, værdimål, absolut værdi og betalingsmiddel $(\S 11)$. Heroverfor fungerer giropenge kun som cirkulationsmiddel og betalingsmiddel og får sit mål fra guldpenge. Giropenge er derfor en pengetype, som er udviklet af varepenge. Indskyderen disponerer over sin saldo ved at give banken instruktioner, ved hjælp af hvilke indskyderen kan i) omdanne kontanter til giropenge (indskud); ii) Overføre giropenge fra hans/ hendes konto til en anden; iii) Omdanne giropenge til kontanter (udtraek). Udtrækkene kan foretages ved hjælp af cheks, som i den tid, der går førend banken får checken, kan passere fra hånd til hånd og på denne måde fungere som cirkulations- og/eller betalingsmiddel. Checken er simpelthen giropengenes repræsentant udenfor banken, deres dualis så at sige.

\section{$\S 53$}

Kapitalerne tilbagebetaler pengekapital, som er vendt tilbage og som truer med at ligge brak, til udlåneren. Dette er kun muligt, hvis kapitalerne atter kan finde passende lånekapital, når de behøver det. Kun da kan den årlige nettoprofitrate blive forøget ved tilbagebetaling af lånekapital gennem besparelser på renteomkostninger og gennem reduktion af den fungerende kapitals størrelse. For den udlånende pengekapitalist betyder tilbagebetalingen af pengekapital rentetab, hvorfor det for ham drejer sig om at genudlåne pengekapitalen hurtigst muligt. Bankerne muliggør - gennem koncentration af pengemarkedet - at ledig kapital kan tilbagebetales med kort varsel 
og genudlånes. Indskyderne anbringer deres penge i banken for at sikre sig en fast rente af deres penge. Banken koncentrerer på sin side den tilgængelige lånekapital og udnytter mulighederne for at udlåne disse penge. De fungerende kapitalister kan henvende sig til banken med deres kortfristede eller langfristede låneansøgninger og opnå bankkredit, som gør det muligt for den lånende kapitalist at disponere over en større mængde giropenge (som til en hver tid kan omdannes til kontanter) end han faktisk har indskudt i banken (overtrak). Udsvingene i størrelsen af den udlånte pengemængde svarende til valoriseringsprocessens betingelser (se $\S 43$ ) reducerer den fungerende kapitals størrelse og forøger således den årlige nettovaloriseringsrate. Denne mulighed for at undgå ledige penge - og på denne måde $\emptyset$ ge profitraten - gør imidlertid den individuelle fungerende kapitalist mere følsom overfor forstyrrelser på pengemarkedet. Især mærkes andre kapitalers valoriseringsproblemer tydeligere.

Bankerne spiller hovedrollen i skabelsen af kreditsystemet, som letter anbringelsen af den samlede samfundsmæssige pengekapital. Udviklingen af kreditrelationer $\emptyset$ ger samtidig de fungerende kapitalers afhængighed af bankerne.

I det omfang Marx behandlede kredit og kreditsystemet i Kapitalen er det indeholdt i tredie bind, 5. afsnit. Engels skriver i forordet til tredie bind, at afsnit 5 har frembudt den »største vanskelighed «: »Her foreligger der med andre ord ikke et færdigt udkast, ikke engang en disposition, hvis omrids kunne udfyldes, men kun et tilløb til udarbejdelse, der i mere end ét tilfælde ender i en ikke-ordnet mængde af optegnelser, bemærkninger og materialer i ekscerptform«. (Rh. 3, 11; K3, 12)

Det første kapitel, som omhandler kredit, »Kredit og fiktiv kapital« (kap. 25), starter med ordene: »En indgående analyse af kreditvæsenet og af de hjælpemidler, det skaber (kreditpenge osv.) ligger uden for vor plan«. (Rh. 3, 518; K3, 413)

Marx diskuterer først vekslen, som »basis for de egentlige kreditpenge« og foretager derpå, efter nogle ekscerpter, en »logisk-historisk « udvikling fra pengehandelskapital til banken:

»I tilslutning til denne pengehandel udvikles den anden side af kreditvæsenet, forvaltningen af den rentebærende kapital eller pengekapitalen som en særskilt funktion for pengehandlerne. Lån og udlån af penge bliver deres særlige forretning. De optræder som formidlere mellem de virkelige udlånere og lånere af pengekapital. Generelt udtrykt består bankforretning i denne henseende $i$ at koncentrere udlånskapitalen i sin hånd til store masser, således at det ikke er den enkelte pengeudlåner, men bankierne, der som 
repræsentant for alle pengeudlånere står overfor de industrielle og kommercielle kapitalister.« (Rh. 3, 521ff; K3, 416).

Herpå følger en diskussion af bankindskuddenes forskellige kilder og derpå en række ekscerpter med korte indskudte kommentarer fra Marx, tillige med et tre sider langt indskud fra Engels. Det følgende kapitel »Akkumulation af pengekapital, dens indflydelse på rentefoden « (Kap. 26) består også hovedsageligt af ekscerpter, især fra parlamentsrapporter. Kapitel 27, som Engels har givet titlen »Kredittens rolle i den kapitalistiske produktion «, behandler for størstedelen aktieselskabet som »ophævelse af kapitalen som privatejendom inden for grænserne af den kapitalistiske produktionsmåde selv.« (Rh. 3, 568; K3, 452; se Eldred 1984, § 37 Aa).

Kapitel 28 hører efter sit indhold til Teorier om Mervardien. Kapitel 29, »Bankkapitalens bestanddele«, introducerer begreberne kapitalisering samt diskontering af veksler, og forskellige aspekter af bankens transaktioner med veksler, indskud og giro diskuteres. De tre kapitler 30, 31 og 32 med den fælles titel »Pengekapital og virkelig kapital « er fra Marx’ side et fors $\varnothing \mathrm{g}$ på - igen blandet op med ekscerpter - at behandle økonomiens konjunkturcyklus i sammenhæng med kreditsystemets mekanismer (især i relation til størrelsen af udlåns-pengekapitalen). Kapitel 33 »Omløbsmidlet under kreditsystemet « består hovedsageligt af ekscerpter fra parlamentsrapporter.

Vi har fulgt Marx hvad angår udviklingen af banken fra begrebet om pengehandelskapital. Ligeledes undersøger vi de generelle forhold og aktiviteter omkring bankhandel (veksler, pengesedler, checks, diskontering, lån og udlån, girotransaktioner). I modsætning til Marx' er vores behandling mere passende anbragt i cirkulationsanalysen, hvilket er muligt for os, da renteformen allerede blev udviklet efter produktionsanalysen ( $\$ 24 \mathrm{ff})$. Marx’ forsøg på at udarbejde en cyklusteori må efter vores opfattelse udarbejdes på et senere trin af den systematisk fremstilling, nemlig i konkurrenceanalysen, hvor overakkumulationen af kapital bliver behandlet. Hovedproblemet er at udsondre den almene begrebslige argumentation - for så vidt denne eksisterer - fra det empiriske materiale om kriserne i England mellem 1848 og 1857.

\section{$\S 54$}

Størrelsen af den fungerende kapital kan også reduceres, ligesom cirkulationstiden kan forkortes, såfremt den industrielle kapitalist eller købmandskapitalisten i stedet for at sælge varer mod kontanter eller kontantsymboler (giro-penge), sælger på (kommerciel) kredit med en veksel, som er et løfte om betaling på et senere tidspunkt, på forfaldsdagen. Den sælgende kapitalist realiserer da sine varer mod en veksel, som repræsenterer penge i fremtiden. 
Ved at modtage varer på kredit, sparer den købende kapitalist sig selv for besværet med at låne pengekapital, eller han undgår at vente på, at den udlagte kapital vender tilbage, således at købet muliggøres. Men som en »nogetfor-noget « -forretning må han betale den sælgende kapitalist en rente i form af en højere pris, som udregnes i forhold til vekslens løbetid. Varepriserne kan således kategoriseres som kontantpriser og kreditpriser. Den veksel, som den sælgende kapitalist modtager, kan anvendes som cirkulationsmiddel for at tilvejebringe yderligere varer, så længe den sælgende kapitalist er villig til at give kredit. Afhængig af det omfang i hvilket vekslerne kan cirkulere, kan et større antal transaktioner blive effektueret. Såfremt kapitalisterne generelt tillader udstedelse af veksler, vil der på forfaldsdagen kun være en mindre saldo at udrede i giro- eller guldpenge.

\section{$\S 55$}

Omfanget af veksel-cirkulation kan øges gennem bankernes engagement $\mathrm{i}$ de kommercielle kreditrelationer. Banken accepterer vekslen og giver sin egen veksel, en banknote (pengeseddel), i stedet. Denne kan dog indløses som kontanter på given foranledning, ikke blot på en specificeret fremtidig dato. Banknoten behøver ikke have form af papirpenge udstedt af banken, men kan simpelthen være en kreditgaranti i form af overtrak gennem etableringen af en bankkonto. Den kapitalist, som konverterer vekslen i en bank, kan da købe de varer han ønsker med bankens kreditgaranti, som er mere umiddelbart acceptabel som betalingsmiddel, så længe der ikke hersker tvivl om bankens solvens. Ved at købe vekslen bliver banken den oprindelige udsteders kreditor og kan kræve vekslen indfriet på forfaldsdagen. Såfremt diskonteringspraksis er udbredt, er det bankerne, der gensidigt anmoder om betaling for de købte veksler hos hinanden som repræsentanter for respektive vekseludstedende kapitalister. Det sæt af transaktioner, som veksler og diskontering gennemløber, sker ved hjælp af en relativ lille mængde guldpenge. Indenfor banksystemet må en clearing finde sted så længe bankerne opfylder deres kunders kreditefterspørgsel. Clearingen af diskonterede veksler indenfor banksystemet svarer til clearingen af checks. Begge aktiviteter reducerer den mængde guldpenge, som er nødvendig til at få varetransaktionerne i økonomien til at glide. Guldpenge anvendes til udligninger mellem bankerne, mens bankens indskydere normalt har mulighed for at ordne betalinger med giropenge.

\section{$\S 56$}

I og med bankerne garanterer kredit ved at tillade indskyderne at overtrække deres giropengekonti (som er den almindelige form for kreditskabelse i 
dag), fungerer bankerne også som skabere af giropenge. Det er nemlig ikke mængden af guldpenge, som indskydes i banker, der udgør overgrænsen for hvad banken kan udlåne til kapitalisterne. Selvom giropenge på given foranledning kan konverteres til kontanter (på dette trin kun guldpenge), udgør indskydernes kontantkrav i praksis kun en procentdel af de totale reserver, og den totale mængde transaktioner, som effektueres med giropenge (som for størstedelen er kredit garanteret af banken) overstiger langt mængden af kontanter, som er nødvendig for clearingen af checks og veksler mellem bankerne. Som den vigtigste faktor i skabelsen af kreditsystemet smidigg $\varnothing \mathrm{r}$ bankerne kapitalens sammenslyngede kredsløb, men overfører samtidig forstyrrelsen i reproduktionen af individuelle kapitaler, eftersom en banks afvisning af at yde yderligere kredit til én af dets kapitalistkunder normalt også forårsager problemer for andre kapitalister, som har ydet kredit til den kapitalist, der har fået afslag på yderligere bankkredit.

\section{Kapitalens reproduktionsproces}

\section{$\S 57$}

Undersøgelsen af den samlede samfundsmæssige kapitals reproduktion tager sit udgangspunkt i den erfaring, at den samlede vareproduktions materielle skikkelse i en given periode, f.eks. et år, har en vis betydning for reproduktionen af kapital og individer.

Samfundets produktionsproces, som den er repræsenteret ved processens produkt, totaliteten af varer, skulle således ideelt set passe sammen med samfundets forbrugsproces, betragtet i dens totalitet som det samlede forbrug i produktionsprocesser, cirkulationsprocesser og individuelt ved arbejderes, kapitalisters (penge - såvel som aktive kapitalisters) og jordejeres forbrug.

Forholdet mellem den samlede produktionsproces og den samledes forbrugsproces formidles af kapitalens valoriseringsbevægelse. Produktionens og forbrugets materielle indhold formidles af kapitalens valoriseringsform i bred betydning, heri indbefattet arbejderes, pengekapitalisters (bankers og indskyderes) og jordejeres deltagelse i valoriseringsprocessen. Dette forhold mellem indhold og form er endnu ikke blevet undersøgt i den systematiske fremstilling. Indtil nu har det været antaget, at vareproduktionsmidler eller cirkulationsmidler, som den enkelte kapital har behov for, findes på markedet. Reproduktionsprocessen betragtes her som reproduktion af kapital og ikke af arbejdere eller andre figurer. Som før antager vi, at der på markedet findes de arbejdere, som kapitalen har brug for, og at kapitalen også råder over passende jordarealer. Restriktio- 
ner, som mangel på arbejdere og jord påfører reproduktionsprocessen, vil først blive undersøgt i konkurrenceanalysen (jfr. Eldred 1984, del IIIc; $\S \S 57 f ; \S \S 65 f f)$. For den samlede samfundsmæssige kapital er der et dobbelt reproduktionsproblem: for det første problemet med at sælge de producerede varer til andre kapitaler eller individer, som forbruger varerne, til priser, som muligg ør, at der skabes en virksomhedsprofit, og for det andet problemet at købe passende industrielle varer, så virksomheden kan fortsætte sin aktivitet som kapital. Problemets to aspekter er hinandens modsatte: Den ene kapitalists eller individs køb af varer er på samme tid salg af varekapital for en anden kapital. Grænsefladen mellem den fuldførte produktionsproces og (den individuelle eller produktive) forbrugsproces er markedet: mødestedet for købere og sælgere. Den producerede vare kan kun formidlet gennem penge gå over i en forbrugsproces. Disse penge optræder så i en kapitals eller nogle kapitalers valoriseringsbevægelse. På dette trin i fremstillingen, hvor kreditsystemet er blevet tematiseret ( $\$ 53$ ), sker pengeformidlingen gennem forskellige kreditrelationer og typer af kreditpenge, som opstår i forbindelse med bankernes aktivitet. Det kan hurtigt indses, at den samlede samfundsmæssige reproduktionsproces er så kompliceret, at en simpel afgrænset analyse er umulig.

Marx introducerer problemet med reproduktionen af den samlede samfundsmæssige kapital på en lignende måde:

»Vi kan nu ikke længere nøjes med at forudsatte - som da vi analyserede den enkelte kapitals produktværdi - at den enkelte kapitalist først kan omsætte sin kapitals bestanddele i penge ved at sælge sit vareprodukt, og at han bagefter atter kan forvandle pengene til produktiv kapital ved at købe produktionselementerne på varemarkedet.«(Rh. 2, 506; K2, 392)

Med henblik på undersøgelsen af reproduktionen indfører Marx et antal yderst restriktive antagelser i fremstillingen, inklusive følgende:

i) Alle varer sælges til deres »værdier « som defineret ved arbejdsværditeorien.

ii) Alle kapitalers omslagstid er 1 år, idet der heri er indbefattet en produktionsperiode på 1 år og en cirkulationstid, som er 0 , og at alle processer foregår synkront.

iii) Cirkulationsomkostningerne er 0

iv) Der anvendes kun en type penge, guldpenge. Der er følgelig ingen kreditrelationer.

Med disse antagelser $\varnothing$ nsker Marx at artikulere, hvordan kapitalens vardireproduktion i en samfundsmæssig skala - udtrykt ved værdiformskategorierne gammel værdi (konstant kapital) og ny værdi (variabel kapital plus merværdi) - konfronteres med brugsværdi-opdelingen på to produktionsafdelinger. Arbejderklassen optræder her som en nødvendig formidler af reproduktionen af den samlede sam- 
fundsmæssige variable kapital, idet klassen bruger den modtagne løn (og på denne måde orienterer sig mod sine behov for forbrug). Marx opdeler den samlede samfundsmæssige vareproduktion på to afdelinger: produktion af produktionsmidler (I) og produktion af individuelle forbrugsgoder (II), og han betragter derefter det samlede samfundsmæssige vareprodukt under hensyn til de tre kategorier: konstant kapital, variabel kapital og merværdi. Hans argument kan læses uden arbejdsværditeoriens antagelse om, at priser svarer til arbejdsindhold. Antagelserne ii), iii) og iv) ligesom opdelingen af den samfundsmæssige produktion på kun to afdelinger (jfr. § 58) simplificerer i ekstrem grad fremstilling af den samlede samfundsmæssige kapitals reproduktion. I modsætning hertil undersøger denne fremstilling kapitalreproduktionen uden disse antagelser med henblik på at vise, hvordan de utallige formidlinger er viklet ind i hinanden i den samlede reproduktionsproces. Med hensyn til antagelse iv) vil vi mere detaljeret i § 59 undersøge pengeformidlingen af den samlede proces.

Da vi ikke anlægger restriktive antagelser, er det ikke muligt at komme med simple taleksempler, som Marx gør. Vi må i stedet for stille os tilfredse med en kvalitativ forståelse af den materielle cirkulation og produktion af varer og den monetære formidling heraf. Når man opgiver den aprioristiske ricardianske arbejdsværditeori, opgiver man også muligheden for at etablere kvantitative love om kapitalens reproduktion udtrykt som erstatning af arbejdsindhold, som i enhver henseende er en ubegrundet ptolemæisk konstruktion. Ikke alene ortodoks marxistisk $\varnothing$ konomisk teori, men også borgerlig $\varnothing$ konomisk teori fors $\emptyset \mathrm{ger}$ at etablere præmonetære »bevægelseslove « for den samlede $\varnothing$ konomiske proces. Disse fors $\emptyset \mathrm{g}$ på modelbygning er baseret på den fejlagtige opfattelse, at værdiformsrelationer kan bestemmes kausalt på grundlag af et eller andet apriorisk, formuafhængigt princip eller i det mindste kan antages på anden måde at kunne beskrives kvantitativt, f.eks. ved matematiske funktioner, som er konstrueret på grundlag af empiriske data. Den værdiformsanalytiske kritik af aprioristiske teorier ${ }^{2}$ er $\varnothing$ delæggende for ethvert fors $\varnothing \mathrm{g}$ på at opstille en forklaring på den kapitalistiske økonomis fænomenale bevægelse ved hjælp af et underliggende, kvantitativt bestemt, præværdiforms væsen.

\section{$\S 58$}

Det samlede samfundsmæssige vareprodukt falder i fire kategorier: varer som har en materiel form, der muliggør, at de kan forbruges af:

industrielle kapitaler (produktionsmidler)

købmandskapitaler som anvendes til varecirkulation

bankkapitaler (midler anvendt ved bankvirksomhed),

2. Leif Hansen, Knud Pedersen, Thomas Stenderup, On methodological problems in economic theory. A critique of aprioristic value theory. Institut for Socialvidenskab, Roskilde universitetscenter, skriftserie nr. 15, 1984. 
og individuelle arbejdere, kapitalister og jordejere (individuelle forbrugsartikler).

Denne kategorisering er udtømmende (på dette trin i fremstillingen), men den udelukker ikke, at mange varer måtte blive konsumeret i alternative sfærer. Svarende til de fire sfærer er der fire aggregerede afdelinger for vareproduktion, som for nemheds skyld antages ikke at overlappe hinanden, dvs. at hvert vareprodukt kan indpasses utvetydigt i netop én forbrugssfære. De fire afdelinger er:

I: Produktion af produktionsmidler.

II: Produktion af varecirkulationsmidler

III: Produktion af midler, som anvendes ved bankvirksomhed.

IV: Produktion af individuelle forbrugsartikler.

Man kan se, at begrebet brugsværdi, som første gang blev introduceret i analysen af produktionen $(\S 18)$, igen indtager en central rolle. Fordi cirkulationsstadierne ikke falder fuldstændig bort for den industrielle kapital, anvendes nogle af varerne, som en industriel kapital køber, strengt taget uproduktivt som cirkulationsmidler. Denne detalje vil imidlertid ikke blive betragtet her.

I stedet for Marx' opdeling af vareproduktionen på to grundliggende afdelinger, har vi en opdeling på fire afdelinger. De to ekstra afdelinger fremkommer, fordi cirkulationsomkostningerne og cirkulationsaktiviteterne ikke ignoreres, og også fordi disses autonome skikkelse som købmands- og bankkapital tages i betragtning. De eneste cirkulationsomkostninger, som Marx behandler i sine reproduktionsskemaer, er samfundets omkostninger ved at opretholde udbudet af guldpenge. Da cirkulationsomkostninger og -tid er vigtige temaer i cirkulationsanalysen, finder vi, at det er en begrænsning i Marx' fremstilling, at der abstraheres fra cirkulationsomkostninger og -aktiviteter.

\section{$\S 59$}

Samfundets totalarbejder falder i seks kategorier svarende til de fire produktionsafdelinger plus sfærerne for handels- og bankaktiviteter. Tilsvarende udlejer jordejerne deres jord til de seks kategorier af fungerende kapital. Det totale vareprodukt distribueres til de forskellige fungerende kapitaler og til individerne vha. købmandskapitalens aktiviteter. Afdeling I's produktion omfordeles mellem de industrielle kapitaler; afdeling II's produktion fordeles til købmandskapitalerne; afdeling III's produktion til bankerne og endelig fordeles afdeling IV's produktion til individuelle arbejdere, kapitalister og jordejere. Fordelingen af produktionens materielle elementer og af vareproduktet komplementeres af penges bevægelse som kapital og som individuelle betalingsmidler for subsistensmidler. Penge indsat i ban- 
ker, uanset hvorfra de kommer, genudlånes som kapital til de fungerende kapitalister. Renten på disse lån strømmer til bankerne, og derefter delvist til indskyderne. Lånekapital og salgsindtægter bruges af de fungerende kapitalister til at købe industrielle varer og til at betale lønninger, rente og jordrente. Indkomsterne, som arbejdere, jordejere og kapitalister modtager, bruges for en del til subsistensmidler, mens resten placeres i bankerne, hvor der tjenes en rente. Ligesom i de marxske reproduktionsskemaer, må penge nødvendigvis på forhånd være til rådighed for at det samlede vareprodukt kan cirkulere. Vi betragter eksemplet med den kommercielle kapital. Med lånt pengekapital køber den varer fra industrielle kapitaler f.eks. afdeling IV. Arbejdere, jordejere og kapitalister køber disse varer enten på bankkredit (§ 53) eller ved at hæve indlån, som har været sat til side fra sidste periodes indtægter. (Det forhold at revenu betales bagud, gør det fordelagtigt for revenu-modtagere at opspare en vis del af sidste periodes revenu-indtægt indtil næste udbetaling af revenu). Den kommercielle kapital får således penge tilbage til at dække udlægget til varelager plus omkostningerne til cirkulationsarbejdere, jordrente og rente, og en rest til virksomhedsprofit (hvis ellers alt er gået glat). Cirkulationsarbejdere, ejere af jord, som benyttes af handelskapitalen, og banken betales revenu, som erstatter det, som blev anvendt til privat forbrug i den betragtede periode. Tilsvarende kan de penge, som den kommercielle kapital udlagde til afdeling IV, anvendes af afdeling IV-kapitaler til revenubetalinger (idet der forhåbentligt bliver en rest tilovers som profit til virksomheden). Disse udbetalte revenuer fylder atter op i de respektive private forbrugsfonde eller afbetaler på gæld til banken. Med hensyn til de renter, som den kommercielle kapital betaler til banken realiserer banken en del af virksomhedsprofitten og kan dække nogle omkostninger inklusive betalinger af rente til indlånere. Delingen af den samlede samfundsmæssige merværdi mellem jordejere, banker, kommercielle- og industrielle kapitaler sker delvist ved direkte betalinger (af jordrente og rente) og delvist ved at der skummes noget af varernes salgspriser, når penge skifter ejermænd, fordi enhver kapitalist opererer med visse »margins « mellem købs- og salgspriser.

På dette trin i fremstillingen har vi følgende typer penge: Guldpenge, giropenge/ checks (§ 52), banknoter/overtræk ( $(55)$ og veksler ( $\$ 54)$. Veksler og banknoter er kreditpenge baseret på giropenge. Giropenge måles i guldpenge. På dette trin er alle pengebenævnelser guldbenævnelser, alle pengetyper kan konverteres til guldpenge. Så længe guld tjener som absolut pengemateriale, nyder de guldproducerende kapitaler en særlig rolle i den samlede reproduktionsproces. De producerer en (præmonetær) vare, som umiddelbart kan antage pengeform og således ekskludere sig selv fra vareverdenen, (som er prisbestemt). (§ 7). 
Mængden af kreditpenge (veksler), som den fungerende kapital kan udstede, afhænger af dens kreditværdighed, dvs. af hvorvidt man kan få giropenge for dem på forfaldsdagen. Mængden af giropenge (overtræk), som bankerne kan skabe udover den mængde guldpenge, som er indlånt i bankerne, begrænses af deres evne til at omveksle giropenge til guld, når det forlanges. Dette har især betydning ved udligningen af bankernes indbyrdes kasseregnskab, som må ske i guldpenge. Mængden af guldpenge, som indlånes i bankerne, tjener således som et anker for alle andre pengetyper ved at sætte en grænse for, hvor mange kreditpenge (veksler, som normalt diskonteres af banker, og giropenge), der kan skabes i kreditsystemet. De guldproducerende kapitaler har således en betydelig indflydelse på kreditsystemet, idet de bestemmer mængden af guld, som hver periode tilføres systemet. En vis mængde af guldproduktionen indgår som produktionsmidler i produktion af andre varer og er således ikke til rådighed for banksystemet. En anden del af guldproduktionen skal bruges til at erstatte den mængde guldmetal, som ved brug er slidt ned. Resten indgår i banksystemet som ekstra indskud. Den samlede mængde af alle typer penge, som er til rådighed for den samlede reproduktionsproces, er indenfor visse fleksible grænser begrænset af mængden af guldpenge i pengesystemet. Salget af producerede varer skal formidles af penge (af den ene eller anden slags), som er i hænderne på kapitaler eller personer. Personer modtager penge enten som revenu (løn, rente, jordrente) eller som virksomhedsprofit. Den samlede fungerende kapital, som banksystemet stiller til rådighed for de fungerende kapitaler, afhænger af størrelsen af indskud i bankerne. Hvis guldpriserne på varer og de forskellige revenuer skal fastholdes, skal der være en tilstrækkelig pengemængde til rådighed. Specielt i tilfældet med udvidet reproduktion (§ 63), er forøgelsen af antallet af transaktioner begrænset af, i hvor høj grad penge er til rådighed og i sidste instans af udbudet af guldpenge. I et vist omfang kan en stigning i pengenes cirkulationshastighed kompensere for mængden af penge, således at samme pengemængde udfører flere transaktioner end før. Den måde, som bankerne organiserer behandlingen af penge, sætter imidlertid tekniske grænser for mulighederne for at $\varnothing$ ge cirkulationshastigheden. Et ekspanderende kapitalvaloriseringsomfang gennem udvidet reproduktion kan således blive forpurret af mangel på guldpenge, der er til rådighed. Selv om den samlede varemasse er blevet materielt forøget, vil den i forhold til tidligere perioder kun kunne sælges for den samme, eller en kun lidt forøget, samlet pris. Varernes enhedspriser ville falde, og de fungerende kapitaler vil på grund af profitklemmen gøre alle mulige anstrengelser for at reducere de nødvendige revenuudbetalingerne. En ekspanderende reproduktionsproces ville kun være mulig, hvis den blev fulgt op af en kontinuerlig opskrivning af penge (deflation), hvilket ville fremtvinge en skærpet klassekamp om indkomsterne, dvs. fungerende kapitaler ville være nødt til at presse revenuerne ned for at kunne fastholde virksomhedsprofitterne. 
Reproduktionsprocessens afhængighed af mængden af guldpenge i banksystemet kan kun undgås ved introduktion af statspapirpenge (lovlige betalingsmidler), som overskærer forbindelsen mellem pengeudbud og udbudet af en speciel (præmonetær) vare. Dette forgriber imidlertid et mere udviklet analysetrin, hvor begrebet statsmagt er udviklet (jvf. Eldred 1984 § 85 og § 91). På dette trin kan det ses, at et vigtigt formål med statens pengepolitik er at forsøge at tilpasse væksten i pengemængden til det, som er nødvendigt i den samlede reproduktionsproces. Men selv da kan tilpasningen af pengeudbudet i banksystemet til de fungerende kapitalers behov kun reguleres aposteriori, efter at den altid svingende pengeefterspørgsel har gjort sig selv mærkbar. Det er ren og skær held, hvis pengemængden nøjagtig korresponderer med den samlede reproduktionsproces' behov. Om noget, skulle staten sigte mod en rolig inflation, som tvinger revenumodtagerne til at kræve mere af de fungerende kapitaler for at følge med. Den modsatte situation med et utilstrækkeligt pengeudbud forårsager deflation, som umiddelbart stiller den fungerende kapital overfor valoriseringsproblemer.

\section{$\S 60$}

Reproduktionen af hver enkelt kapital skal foregå inden for rammerne af den samlede bevægelse af varer, andre produktions- og cirkulationselementer, og af penge, hvis reproduktionen da ellers overhovedet skal ske. For den enkelte kapital betyder reproduktionen, at omkostningerne, som fremkom i forbindelse med kapitalens aktivitet, bliver dækket af indtægter fra salg af varer.

Herudover skulle der blive en profit tilovers til virksomheden. Salget af de producerede industrielle varer afhænger i sidste ende af deres brugbarhed, og om forbrugeren (enten det er et individ eller en kapitalist) er i stand til at betale for varen. I særdeleshed realiserer det enkelte individs indkomst værdien af produkter fra afdeling IV. Vareprodukter, som ikke finder hensigtsmæssig anerkendelse i pengeform vil ikke blive reproduceret af den enkelte industrielle kapital, som det drejer sig om. Den enkelte industrielle kapital må indrette sig efter dets produkters succes eller fiasko med hensyn til at antage pengeform. Handelskapitaler spiller en formidlende rolle mellem de industrielle kapitaler og de endelige forbrugere. De reagerer på, at varebeholdningen er usælgelig eller sælges til utilstrækkelige priser, ved ikke påny at købe fra de industrielle kapitaler. Banker, som handler med varen 'lånekapital', oplever ikke vanskeligheder på grund af varens materielle form som brugsværdi. Penge, som indlånes i bankerne, kan genudlånes, og bankerne skaber selv giro-penge på grundlag af indlån. Hvis disponibel pengekapital (enten kontanter eller giropenge skabt af 
banken) ikke efterspørges af andre fungerende kapitaler, så tjener bankerne ikke rente på potentiel lånekapital. De svarer med at nedsætte renten, både på udlån og på indlån. Dette indskrænker deres mulige virksomhedsfrofit, men forårsager ikke valoriseringsvanskeligheder i sig selv. Bankernes valoriseringsvanskeligheder opstår for det meste ikke på grund af varens materielle form, men snarere som en konsekvens af valoriseringsvanskeligheder for andre kapitaler, som ikke kan opfylde deres kreditforpligtelser. En banks eksistens er direkte truet, hvis de pengehandelsaktiviteter, den udfører, ikke længere er nødvendige for den samlede, samfundsmæssige, fungerende kapital. De omkostninger, som banken pådrager sig ved pengehandelsaktiviteterne, kompenseres i så fald ikke af den effektive efterspørgsel efter dens bankydelser.

Problemet med reproduktion af en individuel kapital drejer sig på ingen måde om at reproducere »værdier « forstået som arbejdsindhold. Der er nærmere tale om problemet med at reproducere investerede pengesummer i et omfang, så de også kan dække en residual virksomhedsprofit. Værdirelationerne er allerede udtrykt i prisrelationer, som bestemmer det omfang, i hvilket det udførte vareproducerende arbejde anerkendes som del af vareværdi-totaliteten og dermed bestemmer hvorvidt de påførte omkostninger kompenseres gennem værdidannelse. Vareverdenens værdi-almenhed, som blev tematiseret allerede i §§ 1ff, komplementeres på dette niveau af en brugsværdistruktur svarende til de særegne produktionsprocessers og konsumtionsprocessers gensidige afhængighed. Produktionskategorierne, som blev indført i $\$ 58$, er en grov differentiering af det totale vareprodukt og dets produktionsprocesser svarende til brugsværdien, dvs. svarende til vareproduktets endegyldige bestemmelsessted i en specifik type konsumtionsproces. Denne kategorisering kunne godt forfines, f.eks. svarende til sondringen mellem fix og cirkulerende kapital. Den kvalitative pointe er imidlertid allerede klar: hvis den indre forbindelse mellem produktion og cirkulation overhovedet etableres, så sker det via en repræsentation af produkterne som vareværdier. Vareverdenens værditotalitet har en relation til produkternes brugsværdi-totalitet, som er bestemt af varernes endegyldige konsumtion. Brugsværdi-totaliteten er en konkret totalitet i modsætning til værditotalitetens abstrakte almenhed. Varens særegenhed (§ 4) spiller således en væsentlig rolle i sammenhæng med den totale samfundsmæssige kapitals reproduktion. Denne særegenhed må ikke desto mindre underlægges pengenes abstrakte almenhed i hvilken al særegenhed udslettes. Produktionsprocessens særegenhed og den endelige konsumtionsproces' særegenhed kan kun formidles gennem værdiudtrykkets abstrakte almenhed i penge. Eftersom produktets værdiform, dets væren-som-vare, først antages post facto, efter dets produktion, så kan tilpasningen af produktionen til konsumtionsprocessens kon- 
krete totalitet på samme måde først foregå post facto med en større eller mindre grad af forvridning af den produktive aktivitet. Da denne post facto tilpasning kun formidles gennem værdiformen, kan den ikke garantere en tilpasning i den rigtige retning. Den individuelle kapitals svar på valoriseringsvanskeligheder, hvor den orienterer sig mod aktuelle muligheder for at forbedre valoriseringen, kan nemt i den næste periode blot forvarre valoriseringsproblemerne. Ethvert misforhold mellem produktion og cirkulation viser sig kun kvantitativt, i prisformen. De kvantitative udsving i priserne, en abstrakt bevægelse i prisformen, kan ikke løse koordineringsproblemerne i en kapitalistisk $\emptyset$ konomi. Uanset denne proces med vedvarende misforhold, så forbliver værdiformen, som den kvalitative, abstrakte form for anerkendelse af det samfundsmæssige arbejde, uberørt af kvantitative udsving. Kun en alternativ form for samfundsmæssig konstituering af arbejdet ville tendentielt sætte spørgsmålstegn ved værdiformen.

\section{$\S 61$}

Man kan skrive en serie simple ligninger, der opløser de samlede priser for varerne, produceret $\mathrm{i}$ hver afdeling $\mathrm{i}$ en given periode, $\mathrm{i}$ omkostninger plus virksomhedsprofit. Eftersom varehandelskapitalens aktiviteter formidler salget af industrielle varer, er der tale om to serier af simple ligninger, hvor hver sereie indeholder fire ligninger - en for hver afdeling. Der ud over er salgspriserne for fødevarerne lig med de samlede indkomster (løn, jordrente, virksomhedsprofit, rente), der er brugt til dem, og bankernes samlede renteindtægter kan opløses i omkostninger plus bankernes virksomhedsprofit. Dette giver ialt ti ligninger. Betragtet som ligninger, der udtrykker værdirelationer mellem dele af det totale produktions-, handels- og konsumtionssystem, udtrykker ligningerne betingelser for reproduktion af dele af den totale samfundsmæssige kapital. Alle virksomhedsprofitstørrelser må være positive for at reproduktionen skal lykkes. Negativ virksomhedsprofit påtvinger en omstruktureringsproces for den afdeling, der er tale om (f.eks. øget effektivitet, forøget omslagshastighed, ophør af visse kapitalers aktiviteter). Fordi værdirelationerne kun resulterer post facto, efter at varerne er blevet produceret og er kommet på markedet, så kan omstruktureringen af produktionen og handelsaktiviteterne kun reagere på de faktiske værdirelationer mellem afdelingerne. Der ud over er pengene og kreditten, som banksystemet skal stille til rådighed for den samlede proces, i en konstant tilpasningsproces. Den materielle reproduktionsproces og selve systemet med pengemæssig formidling kan geråde ud i en disproportionalitet ( $(59)$, som kun kan justeres bagudrettet (og da måske i forkert retning). Kreditklemme og inflation er fænomener, 
som er resultat af et misforhold mellem den materielle og pengemæssige side af reproduktionen.

a) De ti ligninger, som blev omtalt ovenfor, er ikke udtømmende. De udtrykker nogle af de værdirelationer, der eksisterer mellem $\varnothing$ konomiens afdelinger og det individuelle forbrug. Varernes brugsværdi kommer i forgrunden på dette niveau af analysen, skønt brugsværdierne stadig kun er inddelt i fire grove kategorier svarende til arten af deres endegyldige konsumtion. Værdirelationerne (i den udvidede betydning, der includerer lønnen, jordrenten, virksomhedsprofitten og renten som værdiformer) frembringes a posteriori i vareproduktets materielle distribution til de forskellige sektorer i $\varnothing$ konomien og til den individuelle forbrugssfære. Materielle disproportionaliteter mellem det totale vareprodukt og de materielle forbrugsbehov i den produktive, uproduktive og individuelle konsumtion afspejles kvantitativt i værdirelationerne i de priser, der betales for varerne. Priserne er på deres side bestemmende for om - og i hvilken udstrækning - de omkostninger, som de industrielle kapitaler i de forskellige afdelinger har pådraget sig, bliver dækket. Konkurrenceanalysen vil i behandlingen af tendensen til dannelsen af en gennemsnitlig, årlig nettoprofitrate (jvf. Eldred, 1984, §§ 30ff) eksplicit tematisere, hvorledes kapitalerne reagerer på de opnåede priser.

b) Marx refererer til vigtigheden af de industrielle varers brugsværdi, dvs. arten af deres endegyldige forbrug, hvor han introducerer spørgsmålet om kapitalens reproduktion:

»Sålænge vi betragtede værdiproduktionen og kapitalens produktværdi individuelt, var vareproduktets naturalform ganske underordnet for analysen.... For så vidt der var tale om kapitalens reproduktion, var det tilstrækkeligt at forudsætte, at den del af vareproduktet, som repræsenterer kapitalværdien, inden for cirkulationssfæren ville finde lejlighed til igen at forvandle sig til sine produktionselementer og dermed atter tage form af produktiv kapital. Det var også tilstrækkeligt at forudsætte, at arbejder og kapitalist på markedet ville forefinde de varer, som de giver arbejdsløn og merværdi ud til. Denne rent formelle fremstillingsmåde er ikke længere tilstrækkelig, når vi betragter samfundets totalkapital og dens produktværdi.« (Rh. 2, 507-08; K2, 393)

c) Den proces, gennem hvilken der søges skabt en passende relation mellem produktion og konsumtion, er en række af kontinuerte misforhold, som tvangsmæssigt bringes for dagens lys af værdirelationer, der tvinger de producerende kapitaler til at ændre produktionsprocessen eller måske til helt at indstille produktionen. Denne proces, hvor der søges proportionalitet gennem kontinuert disproportionalitet, skaber forstyrrelser af større eller mindre grad. »Selve processens komplicerede karakter giver lige så mange anledninger til unormalt forløb.« 
(Rh. 2.2, 631; K2, 491). Denne unormalitet ved den materielle produktions totale proces i dens kapitalistiske form er et stedsevarende problem. Fors øget på at opnå proportionalitet gennem disproportionaliteter kan enten, ved et tilfælde, føre til en større grad af proportionalitet mellem produktion og konsumtion eller til en endnu større disproportionalitet (jvf. § 60). Dette beskrives i økonomisk teori som en (skadelig) spindelvaevseffekt.

\section{$\S 62$}

Den del af det totale samfundsmæssige vareprodukt, som købes som fix-kapital (produktions- eller cirkulationskapital) sættes i bevægelse $\mathrm{i}$ arbejdsprocesser, hvor den fungerer $\mathrm{i}$ et antal af den cirkulerende kapitals omslag, som sædvanligvis løber op i et antal år. Omkostningerne til fix-kapital slår således kun om i løbet af en lang periode, i hvilken fix-kapitalen i dens materielle form konsumeres gradvis. Den andel af det totale vareprodukt, der finder anvendelse som fix-kapital, udgør således et relativt stort fradrag fra varerigdommen, der kun vil bære frugt (i form af nye varer) over en lang periode. Det totale vareprodukt må have nået en tilstrækkelig størrelse for at kunne tåle et fradrag, som ikke umiddelbart bidrager til den samlede samfundsmæssige individuelle konsumtion (i modsat fald må den samlede samfundsmæssige, individuelle konsumtion - og det vil først og fremmest sige arbejderklassens - begrænses drastisk). Den pengekapital, der er nødvendig til investeringer i fixkapital, må stilles til rådighed af banksystemet. Den del af det totale samfundsmæssige vareprodukt, der består af varer, der kan konsumeres som fixkapital, må finde vej ind i arbejdsprocesser, hvor fix-kapital skal erstattes in natura efter en levetid på adskillige omslag af den cirkulerende kapital. I andre arbejdsprocesser (kommercielle og produktive) behøver fixkapitalen ikke at blive erstattet in natura i den betragtede periode, men $\mathrm{i}$ stedet må der sørges for en afskrivningsfond m.h.p. dens kommende erstatning. Afskrivningsfonden, der består af brakliggende midler, kan stilles til rådighed for banksystemet indtil fonden skal bruges til erstatning af fix-kapitalen. De kapitaler, som erstatter fix-kapital i den betragtede periode, trækker på den samlede samfundsmæssige afskrivningsfond for at købe de nødvendige varer. Eller de køber fix-kapital på varekredit, hvilket muliggør afbetaling over en lang periode. Den kapital, der producerer fix-kapital, må kunne bære en sådan langvarig kredit eller må henvende sig til banksystemet for at diskontere en langfristet veksel. Det grundliggende problem er, at den del af det totale vareprodukt, som er bestemt til brug som fix-kapital, må finde vej til passende arbejdsprocesser, hvor der er behov for ny eller for erstatning af fix-kapital, og omvendt må kapita- 
len, der har brug for erstatning af fix-kapitalen, kunne finde den til rådighed for køb på markedet. I modsætning til flertallet af varer, som anvendes som cirkulerende kapital eller forbruges individuelt, så repræsenterer fix-kapital-varer sædvanligvis en uhyre værdimængde. En enkelt kapital producerer måske kun meget få enheder af en fix-kapital-vare på et år eller ovenikøbet mindre end en enhed. Hvis en eller flere af disse enheder viser sig at være usælgelige eller kun sælgelige til en pris, der er utilstrækkelig til at dække investeringen, fordi den ikke er efterspurgt i nogen arbejdsproces, så er den producerende kapitals valorisering i akut fare. Kapitaler, der producerer fix-kapital-varer, søger at undgå dette problem ved kun at producere mod faste ordrer for på den måde at unddrage sig nogle af markedets lunefuldheder. Størrelsen af det tidsrum, der er involveret, kan imidlertid være så stort, at den kapital, der bestiller fix-kapital-varer til en bestemt dato i fremtiden, meget vel kan befinde sig i en position, hvor den ikke længere har brug for dem eller råd til dem. Eller det kan ske, at den bestilte fix-kapital allerede er overgået teknologisk, når dens produktion er tilendebragt. I så fald er det blot et spørgsmål, hvorvidt den producerende eller ordregivende kapital bærer tabet. Ordresystemet kan ikke ophæve de forstørrede disproportionalitetsvanskeligheder mellem produktion af fix-kapital-varer og erstatning af fix-kapital in natura. Disproportionalitetsproblemerne mellem produktion og konsumtion i den samlede reproduktionsproces dukker op i forstørret målestok i det særlige tilfælde med fix-kapital-varer.

I Marx' behandling af erstatningen af den fixe kapital (K2, kap. 20, afsnit 11) lægges der stor vægt på spørgsmålet, hvorledes pengene til erstatning af fixkapitalen kan fremskaffes. Han argumenterer indenfor rammerne af et simpelt skema, hvor den konstante kapital-komponent i afdeling II (for Marx, konsumtionsmidlerne) skal udveksles mod nyværdikomponenten i afdeling I (produktionsmidlerne) (jvf. Rh 2, 573ff; K2 446ff). Som et resultat af hans forsimplende antagelser (jvf. § 57), kommer han til det resultat, at værdien (målt i penge) af den fixe kapital i afdeling II, som skal erstattes i den løbende periode, må være lig med værdien af afskrivningen af fix-kapital i afdeling II, som endnu skal akkumuleres i en afskrivninsfond. Med vores mere komplicerede skema bliver problemet om erstaning af fix-kapital mere kompleks. Banksystemet skal sørge for fondene til erstatning af fix-kapital. Hovedkilden til disse fonde er andre kapitalers fixkapital-afskrivningsfonde, som temporært er stillet til rådighed for banksystemet. Den kendsgerning, at disse gradvis akkumulerede fonde er indsat i banksystemet, som på sin side kan låne dem til enhver afdeling $\mathrm{i} \emptyset \mathrm{konomien}$, betyder, at balancen mellem nye fix-kapitalinvesteringer og til rådighedstående afskriv- 
ningsfonde ikke behøver at være til stede indenfor hver enkelt afdeling. Der skal blot opnås en balance for $\varnothing$ konomien som helhed. Banksystemets kreditrelationer muliggør blot, at problemet forskydes til det totale samfundsmæssige niveau. Kreditrelationerne muliggør også, at den totale samfundsmæssige afskrivningsfond til erstatning af fix-kapital kan reduceres, eftersom den samme pengekapital kan financiere købet af adskillige fix-kapital fornyelser på forskellige tidspunkter. Den nødvendige pengekapital behøver heller ikke nødvendigvis at være opsparet af de individuelle kapitaler eller af de fungerende kapitaler som helhed, fordi også andre figurer stiller penge til rådighed for banksystemet. Fordi Marx abstraherer fra kreditrelationerne og går ud fra den antagelse, at kapitalisterne arbejder med deres egen pengekapital, så kommer han til det resultat, at de kapitalister, som erstatter deres fix-kapital in natura i en given periode ved at kaste akkumulerede afskrivningsfonde i cirkulation, fremskaffer de penge, som igen kan trækkes ud af cirkulationen af de kapitalister, som stadig sparer op i deres afskrivningsfonde. Under den antagelse, at kapitalisterne opererer med lånekapital, er situationen vendt om: de kapitalister, som lægger noget til side fra salgsprisen på varerne i en afskrivningsfond til senere erstatning af fix-kapitalen, tilvejebringer fondene til banksystemet, som kan lånes til de kapitalister, som ønsker at erstatte den fixe kapital. Fordi Marx abstraherer fra kreditrelationerne, antager afskrivningsfonden skikkelse af pengeophobning i hænderne på kapitalisterne, som ikke lånes til nogen anden kapitalist. Ikke desto mindre leverer hans forsimplede reproduktionsskema nøglen til forståelsen af den fixe kapitals reproduktion. Pengeformidlingen af den fixe kapitals fornyelse er den ene side af problemet. Den anden side er den materielle disproportionalitet, dvs. at de rigtige fix-kapital-arbejdsmidler produceres i de rigtige mængder på de rigtige tidspunkter. Dette sker gennem en flakken rundt i mørket på markedet. Enhver materiel disproportionalitet må tilpasses indenfor rammerne af et kompleks (spindel)væv af a posteriori relationer på markedet. Tilpasningsprocessen kan være af mere eller mindre voldsom natur. På den kapitalistiske $\varnothing$ konomis evigt skiftende sandbanker kan den individuelle kapitalists reaktioner vise sig nøjagtigt at være en forkert reaktion som forværrer disproportionaliteten. De betaler dyrt for deres forkerte 'vurdering' i form af valoriseringsvanskeligheder. Den enkelte kapitalist kan imidlertid ikke holdes ansvarlig for værdiformernes iboende tilfældigheder, - uanset den naive bevidstheds beskyldninger om dårlig ledelse, når tingene øjensynligt går slemt galt.

\section{$\S 63$}

Den totale samfundsmæssige nyværdi udtrykkes i summen af revenuerne plus virksomhedsprofitten, dvs. i summen af de forskellige klassers indkomster, plus den andel af den totale samfundsmæssige værdi, der er nødvendig for at erstatte de konsumerede cirkulationsmidler. Den 
totale samfundsmæssige gammelværdi er på den anden side den sum, der er nødvendig for at erstatte de konsumerede produktionsmidler (jvf. $\S 44)$. Af den samlede sum af indkomster bruges en del til individuelle konsumtionsartikler og den anden del spares op, dvs. indsættes i bankerne og tjener rente som indlånt pengekapital. Dette tillæg til den totale samfundsmæssige pengekapital kan anvendes af de aktive kapitalister, men kun hvis de materielle forudsætninger for dets anvendelse er til stede. Af interesse hér er kun de industrielle varer, som må være til rådighed på markedet, hvis den totale samfundsmæssige fungerende kapitals aktiviteter skal kunne ekspanderes (dvs. spørgsmålet om ekstra arbejdere og jord lades ude af betragtning hér). Disse ekstra varer må besidde den passende brugsværdiform, hvis de skal kunne anvendes i en udvidet reproduktionsproces. Eftersom beslutningerne om at spare eller forbruge indkomsterne tages individuelt, er det et rent tilfælde, om der er korrespondence eller ej mellem varer bestemt for individuelt forbrug og den forbrugte indkomst. Udbudet af varer til individuelt konsum (produkterne fra afdeling IV) kan enten overstige eller være mindre end den samlede sum penge, der er sat til side til forbrug af individuelle forbrugsvarer. Gennem prisændringer og ændringer i forholdet mellem opsparing og forbrug kan de to mængder bringes tilbage i relation til hinanden. På lignende måde har den totale akkumulerede pengekapital kun en tilfældig relation til det vareprodukt, som kan anvendes til udvidelse af individuelle fungerende kapitalers aktiviteter. Gennem mekanismerne på markedet, inclusive pengemarkedet, ændres mængden af akkumuleret pengekapital, ligesom priserne ændres på de varer, som er til rådighed som produktionsmidler eller som cirkulationsmidler. Kapitalens akkumulation og den resulterende udvidede kapitalreproduktion hviler på basis af dens materielle forudsætningen i det samlede samfundsmæssige vareprodukt. Akkumulation er imidlertid et aspekt af produktionen af relativ merværdi ved anvendelse af større mængder af produktionsmidler (fordi forøgelser i produktiviteten i en arbejdsproces ofte er ledsaget af en stigning i produktionens målestok). Udvidet reproduktion svarer således til kapitalens tendens til at forøge sin samlede valoriseringsbevægelse som en karakteristisk relation mellem indhold og form i den kapitalistiske produktionsmåde.

Pengekapitalen, som står til rådighed for den totale reproduktionsproces, finder kun anvendelse som fungerende kapital, fordi en individuel kapital har brug for den for at udvide sine operationer. Denne udvidelse er et aspekt af den relative merværdiproduktion (i den industrielle kapitals tilfælde) eller af formindskelsen af de samlede samfundsmæssige cirkulationsomkostninger (i den cirkulerende kapitals tilfælde). Hvorledes denne udvidelse påtvinges individerne gennem kon- 
kurrencens mekanismer er et tema for konkurrenceanalysen (jvf. Eldred 1984, $\S \S 28,29,35,36)$

»... konkurrencen påtvinger den enkelte kapitalist uden undtagelse den kapitalistiske produktionsmådes immanente love som ydre tvangslove. Konkurrencen tvinger kapitalisten til hele tiden at udvide sin kapital for at bevare den, og han kan kun udvide den gennem progressiv akkumulation.« (Rh. 1.4, 837; K1 618)

»En videnskabelig analyse af konkurrencen er kun mulig, i det øjeblik man forstår kapitalens indre natur.« (Rh. 1.2, 475; K 1335$)$

\section{$\$ 64$}

Den totale samfundsmæssige kapitals reproduktionsproces er reproduktion indenfor uforandrede formrelationer. Produktet produceres som vare indenfor en fungerende kapitals kredsløb, hvor arbejdere under lønrelationen og jord gennem leje indlemmes i arbejdsprocessen. Uanset de kvantitative proportioner af vareprodukt, priser, lånekapital osv., så reproducerer reproduktionsprocessen værdiformsrelationerne.

Klasserelationerne reproduceres og mere specifikt reproduceres arbejderklassen, der i næste periode atter tilbyder sin arbejdskraft til leje for den aktive kapitalist. Bortset fra individuelle undtagelser, så reproducerer arbejderklassens individuelle konsumtion den som arbejderklasse, som levende materiale for kapitalens valorisering gennem produktion og cirkulation. En historisk bevægelse hinsides denne reproduktionscirkel forudsætter den bevidste foregribelse af et alternativ.

a) Marx behandler reproduktionen af kapital-lønarbejderrelationen som et aspekt af kapitalens reproduktion allerede i syvende afsnit i 1. bind (Rh. 1.4, 801; K1 589). Det er slående, at reproduktionen ikke blot undersøges i slutningen af 2 . bind, men også i slutningen af 1. bind. De restriktive antagelser Marx gør vedrørende reproduktionsskemaerne, reducerer effektivt reproduktionsanalysen til produktionsanalysens systematiske niveau. Den eneste begrebslige udvikling i cirkulationsanalysen, som substantielt tages i betragtning, er begrebet om fix og cirkulerende kapital. Bortset fra dette enkelte emne, så adskiller behandlingen af reproduktionen i afsnit 3 i 2 . bind sig ikke substantielt fra præsentationen af det samme spørgsmål i afsnit 7 i 1. bind. Marx' dobbelte behandling af dette emne kan kun fortolkes som endnu et tegn på den kendsgerning, at »Kapitalen ... på trods af Engels' tilføjelser er forblevet en torso«. (H. Cunow. Die Marxsche Geschichte-, Gesellschafts- und Staatstheorie, Bd. 1, Berlin 1920, p. 6).

b) Denne afslutning på den vardiformsanalytiske rekonstruktion af Kapitalen forbereder overgangen til en formanalytisk konkurrenceanalyse. Med 
den tiltagende mystifikation af kapitalprocessen gennem den stadig tiltagende udvendiggørelse af kapitalbegrebet og den voksende rolle som det særegne har spillet $\mathrm{i}$ analysen, er vi trinvis nået det kapitalistiske samfunds overflade, nemlig den фkonomiske konkurrence, båret af individerne, som er drevet frem af partikulariseringen af den totale kapitalbevægelse. Præsentationen kan således ikke hvile på det niveau, vi har nået her. Den læser, som også ønsker at forstå helheden $i$ tanken kan ikke stille sig tilfreds med dette niveau i den dialektiske dialog.

Læs mere om denne kapitalanalyse og dens videreudvikling til statsanalyse $\mathrm{i}$

Michael Eldred:

\section{Critique of Competitive Fredom and the Borgeois-Democratic State}

\section{Outline of a form-analystic extension of Marx's uncompleted system}

\section{Sydney-Konstans Project 1984.}

Udgivet på engelsk af KURASJE

520 sider. Pris: 270 kr. for abonnenter på Kurasje, $360 \mathrm{kr}$. for andre. 


\title{
Kursbuch 78:
}

\section{Lust an der Theorie}

Günter Niklewski, Theorie als Inneneinrichtung / Tilman Spengler,

Stirnwolkenbildung. Ein Plådoyer für theoretische Neugier / Stephen W. Hawking, Grenzen von Raum und Zeit. Versuche, das Universum zu verstehen / Valentin Braitenberg

Tentakeln des Geistes. Vom Nutzen des Denkens in der Forschung /

Erwing Chargaff, Die verfolgte Wahrheit. Der Begriff der Methode in den Wissenschaften / Peter Weingart, Anything goes - rien ne va plus. Der Bankrott der Wissenschaftsteorie /

Sylvia Kade, Der Krieg der Experten gegen die Laien / B. Weinmayer/H. Will/A. Hamburger,

Vom Ich zum Selbst. Der Triebverlust der psychoanalytischen Theorie /

Peter Weigelt, Konzentrationsstörungen. Kopfstände und Bauchtänze auf dem Campus /

Jörg Bopp, Gelibt und doch gehasst. Der Umgang der Studentenbewegung mit Theorie /

Eckhard Nordhofen, Botschafter des Bauchs. Die neuesten Angriffe auf die Vernuft /

Hans Günter Holl, Theorie des Spiels der Theorie / Matthis Dienstag, Das kommt von dem oder der schönne Durst nach Erklärung / Exkurs: Verkauf von Philosophentypen

\section{Kursbuch/Rotbuch Verlag}

\section{Kursbuch 79:}

\section{Der gute Geschmack}

Joseph v. Westphalen, Das Drama des gewissen Etwas / Martin Warnke,

Nachgeschmack / Keto v. Waberer, Schöne Sachen / Gabriele Dietze, Tränen nach

Feierabend / George Tabori, Erste Nacht, letzte Nacht. Geschichte eines Spektakels / Peter-André Alt, Über den neuen Hedonismus / Isolde Schaad, Zürcher Abgeschmecktes /

Micky Remann, Exotische Zungenläufe / Christiane Grefe, Hamburger Dramaturgie Lothar Baier, Phänomenologie unserer Gifte / Stephan Oettermann, Allesfresser, Schau-

Schlucker, Kunstfurzer. Über den Geschmack am anderen / Karl Markus Michel, Der Butzen vom Apfel der Paris. Rückblick auf die Urteilskraft / Michael Sontheimer, Post-Punk und Neo-Rokoko / Cora Stephan, Dessouveränität / Asmus Petersen, Anziehen - ausziehen

Exkurse: Neue Wege der Kunst/Wie teuer ist die Republik?/Das Ende des Grösenwahns

\section{Kursbuch/Rotbuch Verlag}

\author{
Abonnement: 31,50 kr. Enkeltpris 40,50 kr. \\ Tegn abonnement hos Kurasje
}




\section{Metafysikkens praktiske virkeliggørelse \\ - kapitalistisk udviklingslogik \\ i det moderne kaos}

Steen Nepper Larsen \& Lars Petersen

- orienteringsproblemer $i$

Carlsen, Schanz, Schmidt og Thomsen:

Karl Marx og den moderne verden, Gyldendal 1984, kr. 138,50.

I Århus har der som bekendt siden 1970 udviklet sig en bestemt marxistisk retning, der i perioder eksplicit og emfatisk har proklameret sig selv som kapitallogik. Denne betegnelse har vundet stor udbredelse i hverdagssproget på den danske venstrefløj, ofte som negativt ladet afgrænsningskategori.

Anvendelsen af begrebet kapitallogik har været handicappet af dels den århusianske skoles utilgængelige sprog, dels de indholdsmæssige changeringer, denne skole har tilladt sig indenfor sin logik. Netop i lyset af dette har vi med spændt forventning åbnet de fire kapitallogiske tænkeres nyeste bog, der for det første er skrevet forståeligt som introduktion til Marx for et bredt publikum. For det andet må den antages at give en ajourført fundamentalindføring i, præcis hvor den »kritiske potens « pt. lokaliseres hos Karl Marx.

Forfatterne tilstræber »en idéhistorisk forståelse af baggrunden for og udviklingen af hans (Marx'. S\&L) teori.«(s. 7). Der er således tale om en introduktion til Marx, læst via Århus med idéhistoriske briller. Dette giver anledning til en accelererende subjektsammensnoning, hvor forfatternes distance til den åndelige forfader aftager eksponentielt med dennes »modning $«$. Læseren forføres i slutkapitlerne således til at læse den emfatisk samtykkende og selektivt pointerende gengivelse af den modne Marx som et bombastisk postulat om dennes totale og indiskutable aktualitet.

Det skal ikke holdes hemmeligt for læserren af vores undrende kommentar til det nye værk, at vi står i gæld til såvel Marx som århusianerne. Således er der mindst 3 lag - eller snarere 3 subjekter på spil: Marx, Århus-marxisterne og os selv. Som det vil fremgå vælger vi at lægge en afstand til århusianernes autoriserede Marx-interpretation. Desuden er det muligt at tolke Marx' mangfoldige programmatikker og fremstillinger på andre måder end de gængse i Århus.

»Det moderne« er sandeligen kommet på mode indenfor samfunds- 
videnskaben. Fremstillingen af Marx' brudfyldte teoriudvikling indkranses $i$ begge bogens ender af åbenheden $i$ »De moderne tider «. Vi er alle på jagt efter en mening med livet. Hjemløse jages vi rundt $\mathrm{i}$ et netværk af uoverskuelige sociale processer, der synes at løsrive sig fra enhver mening. Vi lever tvivlende $\mathrm{i}$ »målsætningsdiskussionernes tidsalder « (s. 11). Paradoksalt nok viser det sig, at de 4 skribenter mener at have alle svarene på det moderne livs kaos på forhånd. Allerede for over 100 år siden udviklede Marx nemlig gennem kritikken af den politiske $\varnothing$ konomi nøglerne til en begribelse af moderniteten. Mystisk nok blev det moderne allerede færdigudviklet samfundsmæssigt, da det netop brød igennem - og færdigkonciperet af Marx, da han modnedes. Hermed harpunerer forfatterne intentionerne om åben undren og kanoniserer istedet én bestemt Marx-eksegese som apriorisk nøgle. Det er ganske trist.

I anmeldelsen hér er vi ramt af dobbelt undren. Vores »orienteringsproblemer « retter sig både mod den foreliggende bog og den moderne virkelighed, som forekommer os at være en yderst kompleks samfundsmæssighed. Som moderne marxister tvivler vi derfor på bogens aprioriske »sandheder «, da vi gerne teoretisk vil prøve at komme på højde med det kapitalistiske samfunds mangfoldige aktualhistoriske udfoldelser.

Vi lever os dermed fuldt ud ind i de 4's tankegang:

»Orienteringsløsheden er et vilkår, men et vilkår som er historisk skabt - og derfor proncipielt muligt at forandre.« (s. 168).

Spørgsmålet er, om de selv lever op til at leve (med) livet i tvivlens blafrende lysskær.

Fremstillingen af bruddene i Marx' teoretisk udvikling, hans politiske liv og arven fra oplysningstidens tænkere er på mange måder fremragende og præcis. Her kan læseren virkelig spidse $\varnothing$ rer. Vores undren går da også istedet på, at Marx-eksegesen skal gøre det ud for en fyldestgørende teoretisk og historisk begribelse af det moderne som totalitet. Det første og det sidste afsnit af bogen bliver påklistrede legitimationer af Marx’ påståede aktualitet.

Det er ikke fordi, Marx er uaktuel. Men aktualitetens problematik indebærer kaskader af problematikker. Marxismens historie viser f.eks. mange distinkte måder at udlægge Marx' aktualitet på. Og vi stiller os meget tvivlende overfor, at alt skulle være sagt med denne moderne bogs Marxapologi.

Det gælder ikke om at balsamere Marx' teoretiske korpus, men derimod om at unders $\emptyset$ ge om der er »liv « i begreberne (eks. vis udsagnskraft $\mathrm{i}$ kapitalbegrebet), hvis vi stiller skarpt på den moderne kompleksitet - eller om der skal udvindes helt nye begreber, der begrebsliggør historien på en anden måde, end Marx kunne have forestillet sig.

$\mathrm{Vi}$ intenderer ikke at give et direkte referat af bogen, da det allerede er gjort flere steder (f.eks. af en (alt for?) rosende N. Bredsdorff i 
Information, 15/10-84). Derimod vil vi gå et lag dybere ned og forsøge at fremstille de centrale tankefigurer »under« bogen.

Centralt i kapitallogikkens traditionelle læsning af Marx er interpretationsaksiomet, »at den sociale virkelighed er behersket af en bestemt »logik « - et mønster af sammenhænge og udviklingstendenser - der kan afdækkes af en dialektisk fremstilling, som er inspireret af Hegels logik.« (s. 180).

Denne tese forekommer måske umiddelbart indlysende for Kurasjes læsere. Den åbner imidlertid for en række hidtil uafklarede spørgsmål vedrørende denne logiks status. Gåseøjnene omkring »logik « er måske et signal om, at Århus-logikerne nu endelig har tilsluttet sig massen af marxister, der har renonceret på denne afklaring?

Karakteristisk for Århus-skolen har siden den unge Schanz været den motoriske opfattelse af »logikken «, uanset hvordan denne konverterede hegelske tankefigur interpreteredes i den til enhver tid gældende kontekst (en modsatløbende tvivl hos den nyere Lars-Henrik Schmidt vil blive diskuteret nedenfor). Oprindelsen til denne motoriske opfattelse, eller ihvertfald en central formulering heraf findes i Schanz' kapitel »Grundelementer til en rekonstruktion af Kritikken af den politiske $\varnothing$ konomi $\ll \mathrm{i} \gg$ Til rekonstruktionen af Kritikken af den politiske $\varnothing$ konomis omfangslogiske status « fra 1973. Schanz søgte dengang at besvare et spørgsmål, stillet af Hans-Georg Backhaus, nemlig spørgsmålet
»... hvori det erkendelsesledende motiv i værdiformsanalysen ligger hos Marx. Det drejer sig her om en explikation af værdiformsproblematikken.« (»Til rekonstruktionen...«, s. 110)

Det erkendelsesledende motiv formuleredes af Schanz således:

»Idet værdisubstansen sætter sig selv som samfundsmæssig latent værdi igennem konstitutionen af værdiudtrykket (bytteværdien), sættes tillige en bestemt formlogisk udviklingsordnende drivkraft ind i historien... Der er tale om en »subjektiv-reflektorisk « logik, som eksisterer in re, og som har samfundsmæssig gyldighed.«

(»Til rekonstruktionen...«, s. 111)

I 1973 var etableringen af den motoriske »drivkraft «-forestilling tilsyneladende udvundet på baggrund af en historicistisk (fejl-)tydning af værdiformsanalysen i Kapitalen. Dette punkt vil vi ikke tage op her, men blot henvise til siderne 128 og $161 \mathrm{i} »$ Til rekonstruktionen...«.

Imidlertid dukker den selvsamme formulering, kun let tillempet, op igen 11 år efter på side $194 \mathrm{i}$ den her anmeldte bog, denne gang tilsyneladende udlagt $i$ en helt anden dimension:

»Tiden får en selvstændig, skabende og ordnende, kraft i historien. Den er ikke længere blot ramme om historiens indhold, men skaber i høj grad selv dette.« (s. 194)

Hvadenten historiens logik er udsprunget af »en produktionsmåde 
(...) simpel vareproduktion « (»Til rekonstruktionen...«, s. 164), (som alle marxistiske historikere efterhånden er enige om, aldrig har eksisteret, omend Schanz i 1973 baserede sin »explikation af værdiformsanalysen « herpå), eller om den er udsprunget af det kapitalistisk moderne tidsbegreb, så er der tale om en Quasi-begrebsrealistisk »in re«-logik, der driver historien fremad med nødvendig og irreversibel kraft.

På trods af fors $\varnothing \mathrm{g}$ på bogen igennem at rense Marx' aktualitet for forskellige typer historiefilosofi og nødvendighedslogik, bliver resultatet produktion af en ny type historiefilosofi, der er ganske mystisk. I ovennævnte citat feticheres »tiden « og objektiviseres mytisk som overgribende subjekt i og for historien. »Tiden« bliver substitut for værdilogikken - og vi står undrende tilbage. »Logikken« lever selvbevægende i objektet. De århusianske skribenter betoner da også denne strømlinede konstruktion som metafysisk virkelighed, hvor »tankeobjektet « svarer til »realobjektet« (s. 176). Den skarpeste formulering af realabstraktionsteorien kondenseres med følgende utrolige udsagn:

»På den måde (ved gennemsættelse af kapitalen gennem mystifikationerne i den »trinitariske formel $\ll, S \&$ L) bliver den kapitalistiske udviklingslogik så at sige metafysikkens praktiske virkeliggørelse.« (s. 181)

I det århusianske paradigme er der én og kun én »fremstilling, som stem- mer overens med den virkelige bevægelse,...« (s. 176). Det skyldes, at »den virkelige bevægelse selv (hos Marx. S \& L) får tillagt ansvaret for abstraktionsbestemmelserne« (s. 177). Dette muliggør en ganske særlig »overensstemmelse" mellem begreb og realitet, nemlig idet den i realiteten i forvejen herskende logik fordobler sig i fremstillingen af et »tankeobjekt«, altså i en logik, der har dén »adækvate form for overensstemmelse « (s. 175) med den i realiteten sig gennemsættende logik. Den hegelske historisering af fornuftsbegreberne (som man ved Gud ikke skal gå os for snært på klingen om) vendes således om til en radikal »fordoblings-« konception om videnskaben/omtalte »tankeobjekt « som (re-)produktion i 'tankens medium' af en i historien installeret motorisk logik. Det ser flot ud. Men det er måske svært at forstå. Hvad om Kurasjes redaktion lavede et temanummer om denne proklameret socialmetafysiske realabstraktionsmetodologi? Forjættende som den jo må forekomme i den moderne verdens »orienteringsløshed «, indebærer den imidlertid for os at se en række problemer, som vi vil komme ind på nedenfor.

Århusianernes overensstemmelsesteori besidder en dobbelthed. Virkeligheden er prakonstitueret, og begrebet om denne prakoncentret. Begge dele skete omkring 1867. Dermed er teorien udelukket fra at komme i dialog med den historisk foranderlige virkelighed. Dialogen med den moderne mangfoldighed er umuliggjort af det videnskabsteo- 
retiske ståsted. Både den »indre « og den »ydre « rekonstruktion af kritikken af den politiske $\varnothing$ konomi lades i stikken -trods følgende programmatiske forpligtende tilslutning til Marx' projekt:

»Kun redegørelsen, eller sansen for begrebernes historicitet kan afstikke grænserne, inden for hvilke de har gyldighed « (s. 172).

De fastholder ikke rekonstruktionsprogrammet, men lader som om alle problemerne i de sidste 15 års kritisk spørgende Marx-reception er blevet indløst. Samtidig negligerer de, at Marx' »Das Kapital « er en torso.

Med den »indre « rekonstruktion tænker vi på præciseringen af f.eks. værdi- og pengeteorien, som denne foreligger i Marx' forskellige udkast og »færdige « fremstillinger. Det er sikkert futilt og lidt uforskammet at beskylde vores århusianske venner for i denne korte pædagogiske brede formidlingssammenhæng ikke at have fremlagt slige vanskelige sager i deres omfattende utilgængelighed. Men ved at udgrænse Marx' mange ofte (selv)modsigende - udkast og fremstillinger kommer den aldrende herres teori til at fremstå for færdig og strømlinet uproblematisk. Den tvivlende læser føres således en smule bag det blafrende lys - når alle brikker tilsyneladende falder på plads med den moderne Marx. Og det er nu katastrofalt.

Med den »ydre « tænker vi på, at de mange planudkast fra Marx' hånd (Eks. vis bøgerne om staten og ver- densmarkedet) faktisk kunne skrives af energiske sjæle. Påpeges kan det, at staten og verdensmarkedet er forblevet ubegrebne i talrige år. Nu ville det nok være omsonst at prøve at skrive bøgerne om staten og verdensmarkedet ud fra 1867-viden. Indløsningen af en drøm om at komme på højde med virkeligheden kræver netop, at alle nutidige samfundsmæssige fænomener forsøges begrebsliggjort gennem en aktualhistorisk baseret konstitutionskritisk analyse. Dette er et gigantisk projekt.

Vi skal ikke undlade at påpege, at en historisk omfattende sensitiv begrebsliggørelse kan medføre, at rekonstruktionsprojektet slår om i en dekonstruktion. Men det kan selvfølgelig ikke afgøres på forhånd. Det må det konkrete og meget omfattende arbejde vise.

Marx skal således ikke bare skrives færdig, men måske helt om, hvis det viser sig, at en nutidig totalitetstilegnende forskning fordrer en fremstilling, der må bryde med Marx' fremstillingslogik i »Das kapital«. Hvem ved, om vi i 1984 må bryde med »økonomiens « forrangsstilling og udvide genstandsfeltet radikalt. Det kunne jo vise sig, at der er så meget på spil i den virkelige totale samfundsmæssige livssammenhæng, at relationerne mellem eks. vis $\varnothing \mathrm{ko}-$ nomi, sprog, socialisation, erkendelse og frigørelsesforhåbninger må føre til en radikal nytænkning af totalitetens sammenhænge - der afgørende må bryde med Marx' økonomikritiske projekt. Vi gør opmærksom på, at vi hér spiller på 2 heste. For det første 
prøver vi som anakronistiske elementer at tage rekonstruktionsprogrammets ambitiøse problematik alvorligt og at pointere, at dette tilsyneladende er blevet glemt i Århus. For det andet svømmer vi forsigtigt ud på det dybe vand, hvor vi vover pelsen med vores tanker om, at en moderne ambition om at grunde en samfundskritik kan føre til en dekonstruktion af Marx' fremstillings- og begrebs-logik. I denne sammenhæng må vi afstå fra at positivere begge hestevæddeløb for ikke at sprænge anmeldelsens rammer.

Ihvertfald kan vi sige, at kritikbegrebet er skyllet ud med det iskolde badevand i Århus - hvis overensstemmelsesideen tages som fuldgyldigt belæg for, at en moderne aktuel begrebsliggørelse ikke ville kunne kvalificere kritikken af den politiske $\emptyset$ konomi - men at denne blot ligger færdig til brug fra Marx' modne hånd.

Et analogt spor til Marx' kritik af den mest begavede del af den politiske $\emptyset$ konomi som erkendelsesgivende projekt kunne idag også følges. Men også kvalitativt mulige nye indsigter via en skånselsløs kritik af moderne økonomisk videnskab er fraværende som stof $\mathrm{i}$ den århusianske publikation. Vi kræver ikke, at den foreliggende bog skal have det hele med. Men vi mener nok, at en problembevidst marxisme kunne udkaste mulige ideer til økonomikritikkens moderne kvalificering.

For at illustrere vores historiske tvivl på den prækonciperede teoris aprioriske gyldighed, vil vi antyde et par spørgsmål til det, der kaldes for det »kapitalistiske verdensmarked «. Repræsenterer nationalstaten en hindring for dannelsen af en international gennemsnitsprofitrate? Fungerer konkurrencen internationalt idag på en måde, der på nogen tænkelig måde kan belyses vha. den fra Marx overleverede udgave af kritpoløk'en? Politiske indgreb i varecirkulationen og f.eks. eksistensen af multinationale kapitaler må vel umuliggøre en global »sand « teori, der formodes at skulle hoppe direkte fra Marx' 1867-kapitalbegreb hen til den internationale, usamtidigt udviklede kapitalistiske virkelighed idag? I al beskedenhed har vi ca. 300 spørgsmål af denne slags til en nutidig begribelse af verdensmarkedets aktuallogik \& subsumtionshistorie. (Og potentielt lige så mange til »staten «, »sproget « og »sandheden «). I et rent idéhistorisk univers fortoner den »reale « historie sig i tågerne. Det er prisen, de må betale i Århus.

Vi vil nu gribe fat i den emancipationsfilosofiske figur. Vi mener at kunne udskille 3 elementer i Århusskolens frigørelsestænkning. Muligvis indlæser vi vores eget smagfulde perspektiv; men det forekommer os ganske vist, at elementerne 2 og 3 ikke er kongruente - omend tæt forbundne.

»Moderniseringstvangen « (s. 195) er det første element. Det udtrykker bekvemt og substitutagtigt kapitalens iboende akkumulations- og ekspansionstendens. Kritikken af moderniseringstvangen giver sig selv, da århusianernes paradigme udsiger, at fremstillingen af genstandens bevægelse (kapitalens »udviklingslo- 
gik «) i sig selv er kritikken af denne (s. 173, 175, 177, 182). Denne kritik er det andet element. Den unddrager sig således en normativitet, der kunne stå ved siden af eller ganske udenfor genstandens bevægelse (såsom håb, human etik, krop, arrigskab etc.). (Parantetisk må vi hellere pointere, at vi ikke er færdige med at diskutere, hvad der kan danne baggrund for en kritisk normativitet inden for samfundsvidenskaben, som ikke blot reproducerer borgerlige fornuftskategorier eller antropologiske konstanter og andet drømmeri - men at vi mener, at spørgsmålet om kritisk normativitet ikke kan undslippes, som den århusianske emancipationsfigur lægger op til). Endelig er $»$ moderniseringsperspektivet « (s. 195) det 3. element. Med dette produceres mulighed for sprængningen af moderniseringstvangen med »kommunistiske principper « (s. 166). Disse grunder sig systematisk i kapitalens civilisatoriske indflydelse, der forbliver et yderst abstrakt begreb af alt for forjættende støbning - omend det så sandelig også har erkendelsesgivende indhold.

Det forekommer at være næsten lidt for »tricky « at indlejre de 3 elementer i samme uniforme bevægelse. Kapitalismen producerer således »latent kommunisme« (s. 166) - og kritikken af moderniseringsprocessen udspringer som spejlbillede af denne proces selv. Potentielle bærere af frigørelsen udgrænses i denne 3-fløjede selvbevægende figur. Det sociale rum for kommunismeprojektets historiske realiseringsbetingelser sættes ej heller på lyrik. Den bevidste ubestemmelighed af »det gode liv « (s. 192) er en ganske sympatisk pointe for den, der ikke blot vil lade utopier blive tidsbundne negative spejlinger af historisk foranderlige forhold. Men den 3-fløjede figur postulerer nærmest udviklingsautomatisk, at kommunismen vil komme, da den bliver produceret »in re«. Når genstand, kritik og alternativ tænkes i én samtidighed - eksorceres alle utålmodige, historiske og teoretiske revolutionære 10.000 dollars-spørgsmål med bombastiske trylleformularer.

Yderligere kompliceres vores kjærlighed til de 4 tænkere af deres insisteren på civilisationsprocessens »irreversibilitet « (s. 192, 195). De synes at kanonisere den nutidige virkelighed som det til enhver tid gældende »nulpunkt « for alternativitet. Det er nu svært at se, hvorfor vores højt udviklede arbejdsdeling, udgrænsningen af kærlighed og kunst i særlige ghettoer og vareproduktionens samlede system.ikke kan rulles tilbage. Ihvertfald som fromt håb og teoretisk problem. Med irreversibilitetsideen synes de at lukke munden på en selektiv kapitalismekritik. Den 3-fløjede figur er kort sagt alt for abstrakt totaliserende til at kunne overbevise os om andet, end at det virkelige liv i (sen)kapitalismen er ulige mere kompliceret end som så.

I totaliseringens forjættende skær optræder da også populære billedsproglige fremstillinger af kapitalens overgreb »på alle livets områder « (s. 194). Kapitalens herredømme betinger en altomfavnende undertrykkelse af livet. $\mathrm{Vi}$ siger ikke, at dette er forkert; men at det ihvertfald må diskuteres, hvilke 
formidlingsformer og mulige andre »logikker«, der fostrer undertrykkelsen i »almenhed «. Vi undrer os over, at så distinkte begreber som udbytning og undertrykkelse nu sammenrodes og totaliseres. Før har de 4 været grundige med at præcisere »omfangslogik « og »gyldighedsområder «. Nu har de tilsyneladende ikke problemer med at afgrænse begrebernes udsagnskraft mere. De gælder mærkværdigt nok faktisk overalt (i bogen).

Afslutningsvis vil vi åbenbare omridset af en lille love-story. Den ene af bogens forfattere, Lars-Henrik Schmidt, er begyndt at skrive slet skjulte kærlighedserklæringer til Nietzsche. Således ser han med hen-åndende næse og hengivne øjne på Nietzsches begreb om perspektiv $i$ en samtidig $_{\text {« }}$ publikation (»Nietzsches 'næse' «, Slagmark nr. 2, 1984, s. 55).

»Perspektivet giver mening og er ikke et forsøg på at læse en mening ud af noget. Det er to helt forskellige procedurer og Nietzsches kritik af filosofien og videnskaben er præcis, at de tror, at de skal læse en mening ud af tingene. I modsætning hertil vil Nietzsche give tingene mening. Det hedder at anlægge et perspektiv: Vi afslører ikke en skjult mening, vi skaber ved hjælp af perspektivet en meningsfuld sammenhæng.«

$\mathrm{Nu}$ er der ikke i sig selv noget galt i dette radikale standpunkt. Men det må bemærkes med 7-tommersøm, at ideen om at læse IND og ikke UD er i eklatant modstrid med den videnskabsteoretiske opfattelse, som Schmidt i sin egenskab af medfor- fatter udtrykker i den af os anmeldte modernitets-bog. Med realabstraktionsbegrebet og den sociale metafysiks virkeliggørelse kanonise res et immanent perspektiv, der læses UD og absolut ikke IND. Vi kunne forledes til at tro, at Nietzsches perspektiv-indlæsnings-idé blev anvendt på bogens næstsidste side, hvor det håbefulde $\mathrm{i} \gg$ moderniseringsperspektivet « (s. 195) blev dyrket. Men noget sådant er ikke på tale. Her læses nemlig kun UD.

De 4 århusianere har $\mathrm{i}$ bogen et uproblematisk forhold til de store »referenter « (såsom »mening «, »sandhed «, »fornuft «, »totalitet«, »enhed « etc.). Alle de vesterlandske »sandheder « holdes i hævd som positiviteter. Der er ikke tale om, at udfordringer fra eks. vis Foucault eller Baudrillard tages op - eller at Nietzsches radikale kritik af den alt for selvbevidste og selvglade - men illusionsfyldte - videnskab gribes som inspirerende, perspektivisk vinkel. »Disse virkelighetstrompetister er slette musikere « (F. Nietzsche, »Moralens Genealogi«, Oslo, 1969, s. 116), kunne vi fristes til at sige som et ekko af den gamle provokatør.

I en eksplicit kritik af Schanz' nyere civilisationskritiske skriverier, udformer Schmidt da også en klar distance til den bog, han i et svagt $\varnothing$ jeblik har været med til at publiog producere. Civilisationskritikkens projekt spejler sig i det, den gerne vil kritisere. Om denne undslippelsen umulighed i den underfundige cirkularitet, siger han med udmærket præcision: 
»Som filosofi vil den snakke om hele den menneskelige væren organiseret som civilisationen (altså en moderne ontologi på trods af forsikringer om det modsatte), og samtidig vil den være kritik af denne væren uden at have en reference for kritikken, da kritikken selv er en del af væren og formidlet gennem væren. Her er den marxske kritikkonception blevet overtaget af en filosofisk eller romantisk hang til enheden og indskrivelsen $\mathrm{i}$ teorihistoriens stamtavler bliver den egentlige referent og legitimation af procedurerne... $\ll$.

(L.-H. Schmidt, »Romantikken i Praksis «, Kritiske Historikere, nr. 2, 1983, s. 80)

Schmidt synes her at mene som os. At ville indlejre kritikken direkte $\mathrm{i}$ det kritisable er en tak for vildt. Kritikkens forvandling til ontologi er dennes dødlægning. Kritikspejlingen implicerer faren for, at frigørelsen bliver en slags linearitetsforestilling en radikal asymptotisk borgerlighed. En blot lidt mere »fornuftiggjort« civilisation.

Schmidt synes istedet at være på jagt efter noget nyt og spændende. Nye jagtmarker oprulles med munter friskhed af den nye »aktive nihilist«. Schmidt kunne da også på et møde om civilisationskritik blandt Kritiske Historikere på Københavns Universitet, 1. marts 1984, forholde sig med stor distance til fundamentet for hangen til videnskabelighed. Videnskab fremstillede han som den moderne verdens værdisystem, som en sikkerhedsgivende metafor - og teorien i videnskaben som en fordobling af virkeligheden. Det vil komme for vidt at kommentere alle de steder, de to herrer Schmidts samtidige skriblerier synes at være i modstrid med hinanden. Men vi finder, at han Schmidt nr. 2 - er ude i et vigtigt (selvkritisk?) ærinde - og at han er på vej mod at opløse alvorens faste lukkede systemer. Med sans for det provokatoriske, der så godt som fuldstændig er fraværende i »Marx og den moderne Verden«, Afsluttes »Romantikartiklen« med en hyldest til den befriende eksperimentering hinsides den gamle drøm, sat af det enheds-søgende »vidensregimente « (»Romantikken....«, s. 91):

»Hvorvidt mit perspektiv er bedre end andre perspektiver er i bogstaveligste forstand et spørgsmål om teori som æstetik - men nogen har en god og andre en dårlig smag - og her bliver man så svar skyldig. Jeg kan ikke referere til sandheden, eller til dens moderne variant, til virkeligheden.«

(»Romantikken...«, s. 89)

Schmidt reconcerer således på objektive »sandheder« og aprioriske systemer. At udlægge Marx bliver et spørgsmål om smag. Teorien skal lugte godt - for at næsen skal blive kastet ud i sulten længsel. Vi skal ikke her vove os ud i en alt for lynsnar bedømmelse af denne »nye« historie- og teorirelativistiske subjektive hang til den æstetiske og personlige smag. Ej heller til Schmidts vinken farvel til »virkeligheden« som referent. Som før nævnt er vi selv i tvivl om realabstraktions-logikkens pricipielle gyldighed. 
Endnu engang må vi fremhæve nutidens virkelige samfundsmæsdet besynderlige $i$, at bogen, vi hér sighed overbevisende uden aldrende har dissekeret gennem finurlige rønt- besværgelser om aprioriske »sandhegen-gennemlysninger på kryds og der «.

tværs, er så lukket og ude af stand til at tage nyere begavede teoretiske udfordringer op, åbne for nye analytiske perspektiver og begrebsligg øre

Alt er ikke sagt med Marx.

Ej heller med Århus-marxisterne.

Og da slet ikke med os. 


\title{
Noget om dét som er og dét som bør være.
}

\author{
Til forsvar for dialektikken og den immanent begribende \\ fremstilling af det bestående og dets ophovelse.
}

Jens Henning Rasmussen

Steen Nepper Larsens og Lars Petersens »Metafysikkens praktiske virkeliggørelse - kapitalistisk udviklingslogik i det moderne kaos « rejser ikke blot spørgsmål ved den århusianske »kapitallogik«, men ved det programmatisk/teoretiske grundlag for hele den nyere »rekonstruktionsmarxisme $\ll i$ bredere forstand.

Dette sker i to sammenhænge eller omgange. Dels i problematiseringen af dét, som NL/P kalder den »socialmetafysiske realabstraktionsmetodologi . Dels i overvejelserne om nødvendigheden af en særlig »kritisk normativitet«, der kan stå »ved siden af eller ganske udenfor genstandens bevægelse«. Sidstnævnte motiv munder kontant ud i artiklens afsluttende Nietzschekoketteri, som forfatterne med visse forbehold synes at dele med Lars-Henrik Schmidt, når denne ikke optræder som eksponent for den mere traditionelle århusianske »kapitallogik « sammen med Carlsen, Schanz og Thomsen i »Karl Marx og den moderne verden $\ll$.

Hensigten med de følgende indvendinger mod NL/P's artikel er for såvidt ikke at tage »kapitallogikken « i forsvar, og slet ikke at vurdere kritikkens berettigelse specielt $i$ for- hold til »Karl Marx og den moderne verden «. Blot mener jeg at NL/P's fundamentale tvivlssætning ved »kapitallogikken«s og i bred forstand hele »rekonstruktionsmarxismen «s grundteoremer ikke bør stå uimodsagt. I det principielle indhold og perspektiv er der her ikke tale om et enkeltstående fænomen, men derimod om en tendens, der synes at brede sig blandt akademiske marxister. Netop søgningen mod en selvstændig »normativitet « og en større »positivitet « er vel et gennemgående motiv i flere af tidens nye moder, lige fra Negt/Kluge's diffuse »Eigensinn « over Habermas' »kommunikative handling « til begejstringen for Nietzsche's næse. At denne søgning går i forskellige retninger og udmønter sig i ganske forskellige resultater kan ikke skjule det fællestræk, at der faktisk søges. Selv den århusianske »kapitallogik «, som her ellers forholder sig forsigtigt og kritisk, nærmest puritansk, undgår ikke selv at være udtryk for den orienteringsløshed og uro, som hævdes at karakterisere »det moderne«.

I det følgende tjener NL/P's formuleringer kun som typiske udtryk for nogle af tidens tankebaner blandt 
marxisterne. På den ene side vil dette givetvis føre til ganske uberettigede overspilninger af forfatternes faktiske standpunkter. På den anden side kan dette måske også vise sig helt skævt som bidrag til en bredere diskussion. Men en diskussion skal jo starte et sted og i en diskussion kan den skarpe markering også have sin klargørende værdi.

\section{Den »socialmetafysiske realabstraktionsmetodologi $\ll$.}

I en første omgang forekommer NL/P's kritik af dét, som de kalder den $»$ socialmetafysiske realabstraktionsmetodologi «, kun alt for rammende. Hverken »kapitallogikken « eller andre af tendenserne indenfor den såkaldte »rekonstruktionsmarxisme« har formået at udvikle den kritiske teori om kapitalismen i nævneværdig grad. En masse kloge ord og åndrigheder, bevares - men egentlig teoriudvikling, nej! I visse henseender ligner det mere afvikling end udvikling, gennem den grundige akademiske skepticisme tømmes teorien for stadig mere indhold.

Alle fors øgene på systematisk og ekspliciterende gentolkning af den Marxske teori er forblevet indenfor abstrakte blokeringer. Dels har bidragene oftest mere karakter af metateori end teori, genstanden er mere den marxske teoriformulering end det kapitalistiske samfundssystem. Og dels forbliver de egentligt teoretiske udsagn også mærkværdigt overordnede og begrænsede. Trods programintentioner om begribelse af »den ejendommelige logik i den ejendommelige genstand « ender det over den manglende udførelse i ganske grove kompensatoriske in-reerklæringer af de almene teoretiske væsenskategorier. Tilsvarende bliver det også kun til temmeligt ubehjælpsomme famlerier i den rå empiri, som for det meste blot reproduceres uden dybere formidling. Det er her desuden karakteristisk, at teorien ikke bare forbliver abstrakt-almen og uden alvorlig specifitet i forhold til kapitalismens historiske udviklingskvaliteter og særegne formtransformationer; den falder også i en række detailspørgsmål håbløst bag om de begrebssætninger, som - måske nok kun fragmentarisk og usikkert, men alligevel - er gjort tidligere i teorihistorien.

Men trods dette, så begår $\mathrm{NL} / \mathrm{P}$ alligevel en temmelig grov sammenblanding og forveksling af problemerne, når de kritiserer teorien for at være abstrakt og mystisk. De differentierer ikke nærmere mellem program og indlæsning, intentioner og resultater, men lader kritikken af de faktiske indløsningsfors $\varnothing \mathrm{g}$ danne argument for en forkastelse eller i det mindste en tvivlssætning af de programmatiske ideer. Og netop i spørgsmålet om den »socialmetafysiske realabstraktionsmetodologi « viser denne udifferentierede synsvinkel sig mere destruktiv og forvirrende end godt er.

$\mathrm{NL} / \mathrm{P}$ synes ikke at skelne mellem det principielle indhold i karakteriseringen af kapitalherredømmet som en "praktisk virkeliggjort metafysik « og så det eventuelt mystisk-metafysiske i en dårlig teoretisk begrebssætning af dette. 
Den af århusianerne fremførte metafor, som vist endda stammer fra Marx selv, at kapitalherredømmet har karakter af en objektiv, praktisk virkeliggjort metafysik, er for mig at se en ganske udmærket og dækkende dom over den kapitalistiske økonomi og dennes sanseligt-oversanselige, mystisk-tingsliggjorte og subjektiverede herredømmeobjektivitet overfor de blindt objektiverede menneskelige subjekter. Den blotte karakteristik af denne underlige kapitalistiske virkelighed som »praktisk virkeliggjort metafysik « er selvfølgelig ikke videre meddelelsesfuld, men dog egentlig ganske træffende og harmløs. Og videre er den også klart teoretisk programmerende. For teorien indebærer den en opgave, et krav om sammenhængende og opklarende begrebslighed, der ikke blot kan afsløre og kritisere denne objektive »socialmetafysik «, men også netop forklare at den er og hvordan den er en sådan objektiv »socialmetafysik «.

Problemet er altså ikke selve tesen om kapitalherredømmet eller den $\varnothing$ konomiske tingslighed som en objektiv »socialmetafysik «, men derimod den teoretiske begrebssætning, som skal forklare og kritisere denne. Denne teoretiske fremstilling og begrebssætning må selvfølgelig ikke selv antage metafysisk karakter. Det er her, at NL/P's kritik har sin rationelle og begrundede sandhed. Hvis teorien ikke kan forklare den objektive »socialmetafysik« omkring den kapitalistiske subjekt/objekt-fordrejning udtømmende, men kun kan levere abstraktprogrammatiske almenheder og kun kan kompensere for sine blokeringer i grove postulatoriske inre-erklæringer (af »værdiabstraktionen «, »kapitalen i almenhed «, »udbytningslogikken «, »værdiloven «, »moderniseringslogikken«, »civilisationsmodellen« eller hvad ved jeg), - ja så bliver teorien selv mystisk, metafysisk ontologiserende. Og at dette er tilfældet, ikke blot i »kapitallogikken«, men bredt i »rekonstruktionsmarxismen «, kan vel vanskeligt benægtes.

Med manglen på en sådan differentiering og stedfæstning af problemerne bliver NL/P's kritik af den »socialmetafysiske realabstraktionsmetodologi imidlertid uklar. Det er faktisk temmeligt skæbnesvangert for hele budskabet og perspektivet. Hos NL/P synes det problematisk overhovedet at tænke i det programmatiske teorem om en objektiv »socialmetafysik«. Det mystiske og forklaringsbehøvende i den abstrakt blokerede teoriudførelse gøres til argument mod selve grundteoremet. $\mathrm{Nu}$ ø jes NL/P godt nok med kun at sætte spørgsmålstegn ved det hele, de fremsætter ikke antydningen af et alternativ. Men i hele grundopstillingen af spørgsmålet er tendensen mere forkastelse end overvindelse gennem videreudvikling. NL/P foreslår ikke konstruktivt de abstrakte og mystiske blokeringer i teorien overvundet gennem konkretisering, men benytter i stedet lejligheden til at betvivle hele det teoretiske projekt fra grunden.

Nuvel - NL/P kan muligvis mene det helt alvorligt og faktisk betvivle teoremet om kapitalismen som en 
slags objektiv »socialmetafysik «. Og under alle omstændigheder er det fuldt ud berettiget at foreslå en afklaring af, hvad den »socialmetafysiske realabstraktionsmetodologi « egentlig går ud på. Men for mig at se fører det ingen vegne hen at forkaste den. Og da slet ikke i denne grovkornede, udifferentierede form. Trods alle begrænsninger og mystiske indslag er det involverede grundteorem netop en af »kapitallogikken «s store og lovende fortjenester, som ikke bør opgives. Det interessante og præcisionskrævende er selvfølgelig udførelsen og dermed andendelen af NL/P's kritikgenstand - »realabstraktionsmetodologien « -, men ud fra NL/P's behandling strander diskussionen allerede på førstedelen, nemlig om det overhovedet er rimeligt at arbejde ud fra et teorem om en objektiv »socialmetafysik «. Selve termen »socialmetafysik « kan være ligegyldig, men den implicerede virkelighedsopfattelse omkring tingsliggørelsens forbenende fordrejningsrealitet, om væsens/fremtrædelsesforholdenes dæmoniserende list, om objektivt overgribende udviklingssammenhænge og - lovmæssigheder etc. må fastholdes.

\section{Immanent eller normativ kritik.}

Selvom NL/P blot sætter forsigtige spørgsmålstegn ved en række »rekonstruktionsmarxistiske« grundteoremer, hvor de ikke klart markerer hvor alvorligt de selv mener det, så er det ført temmeligt konsekvent igennem. Således fører deres kritik af den »socialmetafysiske realabstraktionsmetodologi« også over i en mere eksplicit tvivlssætning af selve det dialektisk begribende fremstillingsprogram og dettes immanente kritikbegreb.

I forhold til den århusianske »kapitallogik«s senere beskæftigelse med »moderniteten «, hvor fremstillingen af den kapitalistiske moderniseringstvang angiveligt samtidigt skal være dennes kritik, siger NL/P:

»Denne kritik er det andet element. Den unddrager sig således en normativitet, der kunne stå ved siden af eller ganske udenfor genstandens bevægelse (såsom håb, human etik, krop, arrigskab etc.).«(s. 169).

Som konsekvens fremhæver NL/P videre, at det tredie element - i forhold til genstanden og dennes immanent fremstillende kritik -, overskridelsen eller alternativet, dermed ikke bare bliver ganske ubestemmelig, men også åben for dét, som Lars Qvortrup engang har kaldt utopiens »dæmonisering « med den eksisterende kapitalistiske rationalitet. Med den meget sparsomme teoretiske fremstilling og den abstrakt blokerede, rent programmatisk forsikrende kritik fortoner forskellen mellem kapitalistisk og kommunistisk »modernisering « sig i det uvisse med åbenlys fare for rent evolutionistiske og reformrationalistiske emancipationsforestillinger.

Ganske uagtet den større eller mindre berettigelse i denne kritik må jeg også her gøre indsigelse mod NL/ P's grundopstilling af problemerne. I 
stedet for at søge »kapitallogikken «s begrænsning i dens abstrakte blokeringer og manglende konkrete udfoldelse, bliver der her sat spørgsmålstegn ved selve grundideerne. Konstateringen af problemer i udførelsen bliver her til et angreb på selve den immanent dialektiske fremstillingsmetode. Det forhold, at den århusianske »kapitallogik « ikke fremstiller særlig meget og dermed heller ikke udfolder en egentlig kapitalismekritik særlig konkret, bliver hos NL/P til argument mod selve fremstillingsideen og dennes kritiskmaterialistiske, anti-moralistiske grundsyn om den koldt iagttagende blotlægning af den indre kontinuitet og diskontinuitet mellem dét som er og dét som bør være, mellem det bestående og dets overvindelse.

Dette ret destruktive perspektiv er også indholdet i hele den afsluttende smart polemiske spillen Lars-Henrik Schmidt »den Anden« ud mod den mere traditionelle »kapitallogik «:

»Schmidt synes her at mene som os. At ville indlejre kritikken direkte i det kritisable er en tak for vildt. Kritikkens forvandling til ontologi er dennes dødlægning. Kritikspejlingen implicerer faren for, at frigørelsen bliver en slags liniaritetsforestilling - en radikal asymptomatisk borgerlighed. En blot lidt mere »fornuftiggjort« civilisation«. (s. 169).

Dette er jo en ganske radikal kritik og har jo også et eller andet sted en rationel pointe. Men i denne form er den ikke desto mindre forkert og ved siden af. Eller rettere: en radikal og måske rimelig kritik bliver her anvendt til et forkert formål, nemlig et regelret angreb på den kritiskmaterialistiske og dialektiskimmanentiske fremstillings- og begrebsmetode. Dét forhold, at dialektik kan fås i mange udgaver og ligesom den ældre Hegel eller højrehegelianerne kan ende med en rent evolutionær og apologetisk forsoningsdialektik, bliver her til et angreb på dialektikken overhovedet og ikke til et spørgsmål om dialektikkens art. Ud fra den blotte mulighed, den rene »fare «, for den immanent begribende tænknings bevidste eller ubevidste forsoning af og med det bestående, slutter NL/P tilsyneladende en nødvendighed og smider det hele over bord.

Sammen med Schmidt »den Anden « kokketerer NL/P med Nietzsche og ideerne om ikke at »læse en mening ud af noget «, men i stedet at »læse ind « og »anlægge perspektiv «. NL/P synes godt nok at tage forbehold og tøve en kende overfor Schmidts helt subjektivt relativistiske konsekvens omkring teoriens forvandling til ren æstetik og personlig smag eller temperament. Men overhovedet at formulere spørgsmålene på denne måde og lege med ideerne er ikke så lidt af en opblødning og distancering fra hele »rekonstruktionsmarxismen «s væsentligste grundlag siden Alfred Schmidt, H.J. Krahl og Roman Rosdolsky tilbage i de glade tressere.

$\mathrm{NL} / \mathrm{P}$ fors $\emptyset$ ger godt nok efter den første forbløffende formulering s. at tage forbehold og berolige den chokerede læser: 
»Parantetisk må vi hellere pointere, at vi ikke er færdige med at diskutere, hvad der kan danne baggrund for en kritisk normativitet indenfor samfundsvidenskaben, som ikke blot reproducerer borgerlige fornuftskategorier eller antropologiske konstanter og andet drømmeri - men at vi mener, at spørgsmålet om kritisk normativitet ikke kan undslippes, som den århusianske emancipationsfigur lægger op til.« (s. 171).

Ok - jeg skal straks komme tilbage til spørgsmålet om den »kritiske normativitet «i den immanent dialektiske begribelse af kapitalismen, men fastholde det vanvittige og udsigtsløse $i$ at søge »ved siden af eller ganske udenfor « kapitalismen for fra denne udvendighed at begynde at »læse ind « og »anlægge perspektiv«. En sådan form for »normativ kritik « og »transcendens « er et fald bag om hele den Hegel-oplyste venstremarxisme siden Korsch og Lukåcs og en åbning mod netop den »kriticisme«, som teorihistorisk karakteriserede revisionismen, nemlig neo-kantianismen og den etiske socialisme. NL/P synes selv at ane problemet og sværger mod den borgerlige fornuftsmoralisme. Men hvad kan der ellers komme ud af det, hvis den »kritiske normativitet « ikke selv må være »afledt « $\mathrm{i}$ teoriens genstandsfelt, når kritikken netop ikke må betragtes immanent som del af det kritisables egen udvikling?

Formuleringen om en særlig kritisk normativitet, »der kan stå ved siden af eller ganske udenfor genstandens bevægelse«, bliver ganske absurd, når man som ovenfor kalder tingene ved navn og gør kapitalismen til den kritisable genstand. Dette kan selvfølgelig aldrig have været NL/P's alvorlige mening med formuleringen. Men hvad er så den kritisable genstand? Det involverede genstandsbegreb er ganske åbenbart ikke den konkrete totalitet, men et ikke nærmere defineret udsnit. Også i denne henseende indeholder hele synsvinklen et brud med traditionen. Da vi her ikke får andet at vide om afgrænsningen end at det åbenbart ikke indeholder faktorer som »håb, human etik, krop, arrigskab etc.«, Øjensynligt ganske tilfældigt valgte eksempler, skal jeg ikke her kunne sige, hvad det drejer sig om. Blot kan man på rent erkendelsesteoretisk grundlag sige, at uanset hvad dette begrænsede udsnit måtte være, så er der her tale om en stærkt problematisk abstraktion, som ikke kan holde til ret meget. Og om den i den helt konkrete polemiske sammenhæng overhovedet stemmer overens med genstandsbegrebet for den århusianske »kapitallogik « forekommer mig også tvivlsomt - men dét er en lidt anden sag.

\section{3. »Normativiteten « i den imma- nent fremstillende begribelse.}

Spørgsmålet om den »kritiske normativitet « i den immanent dialektiske begribelse af kapitalismen bliver ikke nedblændet i den århusianske »kapitallogik« pga. dennes bekendelse til det marxske fremstillingsprogram. På trods af må man snarere sige. Konkret begrebssætning og dermed konkret kritik er bare ikke noget man giver sig særligt af med, mere noget man kun taler om. Deraf nedtoningen. 
Men derudover har NL/P's indvending selvfølgelig den rationelle pointe, at fremstilling og kritik ikke går restløst op i hinanden. Fremstillingen af kapitalismen i teoretisk reproduktion er kun kritikken af samme helt generelt og i samlet udstrækning. Hvad angår enkelte delområder og enkelte kategorier, dér er fremstillingen ikke nødvendigvis altid kritisk ligesom kritikken omvendt ikke altid er nedlagt i fremstilling. På forskellige områder og i forhold til forskellige kategorier er kritikmomentet endvidere af forskellig art.

Hvad angår det overordnede, at teorien er fremstilling og netop derigennem kritik af kapitalismen, bunder det dels i den erkendelse, at kapitalismen selv gennem sine modsætninger og indre splid producerer og formidler den praktiske kritik af sig selv, og dels i den videnskabelige nøgternhed, at der for den begribende tænkning ikke kan findes andre målestokke end genstanden selv. Udtrykt i den dialektiske logiks groveste og mest barbariske ABC tager fremstillingen sig således ud: den enhedsmæssige genstand viser sig ved nærmere betragtning at være differentieret ved væsentlige og konstitutive forskelle; disse forskelle viser sig at være modsætninger, disse modsætninger atter at være modsigelser; og over disse modsigelser vil genstanden enten atter finde forsoning i en ny differentieret enhed på højere niveau eller også vil den blive sprængt over de modsatte ekstremers skærpelse til absolut uforenelighed. Det eneste teorien behøver at foretage sig er den fuldstændig køligt registrerende og forklarende fremstilling af denne genstandens egen processerende splid med sig selv.

Dette betyder selvfølgelig også mere konkret, at man i den immanentisk reproducerende fremstilling af kapitalismen ikke sidder inde med den »kritiske normativitet « a priorisk, hverken som noget der er fundet $\gg$ ved siden af eller ganske uden for « genstanden, eller som noget der automatisk er sikret med det rene program, den rene intention om immanent fremstilling. Den virkeligt kritiske instans, som også bærer det overskridende potentiale og perspektiv, fremkommer i og af kapitalismen selv, i de praktiske modsigelsers faktiske bevægelser, deres praktiske udladninger i åbne konflikter og tvungne forsoninger. Følgelig opstår den kritiske »normativitet « $\mathrm{i}$ teorien også først på rette tid og sted i og gennem den konkrete fremstilling på basis af den konkrete forskning, den kritiske iagttagelse.

Den kritiske instans og subjektivitet i genstanden selv blev af Marx lokaliseret i lønarbejdet og dets affødte klassebestemmelse: arbejderklassen og begrebet om proletariatet som kollektivt subjekt. Her henter teorien sin referenceinstans og dermed sin »normativitet «. Med den immanent dialektiske totalitetsbetragtning og den kritisk-materialistiske begrebssætning af kapitalismens opkomst og udvikling er lønarbejdet og den af kapitalforholdet udspringende klassekamp udpeget som det afgørende og potentielt sprængende konfliktpunkt i kapitalismen. 
Med den begrebslige blotlægning af lønarbejdets konstitutionsforhold og klassekampens reale udviklingsbetingelser og determinationer har teorien ikke blot fundet sin virkelige årsag og forudsætning, men også netop konkretiseret spændingsforholdet mellem dét som er og dét som bør være i genstanden selv. På den ene side går enhver selvstændig moraliserende kritik og normsætning her under i den rationelle begribelses immanente og rent registrerende kølighed. På den anden side mister teorien samtidig enhver karakter af forudsætningsløs og blot neutralt anskuende »objektiv Wissenschaft «. Teorien kan over den åbenbarede modsætning og kamp i kapitalismen ikke enhedsmæssigt og neutralt være den samlede kapitalismes, den samlede civilisations eller blot »tiden «s kritiske aflæggen regnskab for sig selv, men må nødvendigvis blive partisk. Teorien må indtage et proletarisk klassestandpunkt eller et borgerligt, kapitalistisk rationalitetsstandpunkt.

For at undgå misforståelser skal det her fremhæves, at teoriens partiskhed i forhold til de kapitalistiske produktions- og klassemodsætninger på ingen måde er et moralsk anliggende. Partiskhed er et objektivt vilkår for enhver teori - dét må være indlysende for enhver kritisk totalitetstænkning, der er i stand til ikke kun at reflektere sig selv overfor, men også i sit genstandsfelt. Teori er uundgåeligt og uden flugtmuligheder partisk i forhold til kapitalismens modsætninger selv hvis den af skepticistisk usikkerhed eller borgerlig akademisk hov- mod mener sig udenfor og hævet over sin genstand i den $»$ rene anskuelse «s kontemplative $»$ udvendighed $«$. Dette foranlediger ikke et spørgsmål om moral, men om konsekvent metode: kun med bevidstheden om partiskhedens uundgåelige nødvendighed kan teorien vinde en kritisk frihed til selv at fastlægge og udøve denne partiskhed i overensstemmelse med sig selv, herunder hæve sig ud over alle den moralske umiddelbarheds faldgruber af empirisme, spontanisme, dogmatik, voluntarisme, religiøsitet og andre irrationaliteter.

Den kritisk transcenderende »normativitet « i den immanent dialektiske betragtning af kapitalismen er altså forankret i den proletariske klasseidentifikation. Gennem den ganske kølige og af aprioriske forudsætninger uforstyrrede iagttagelse af kapitalismens opkomst og udvikling kommer de udbyttedes og undertryktes utilfredshed og kampe uundgåeligt frem i lyset som dén praktiske kritikinstans i genstanden selv, der gennem udvikling og modning kan hæve sig ud over det beståendes rammer og iværksætte en praktisk forandring. Referencen er her ikke den bestående klasse af lønarbejdere i dens momentant foreliggende, empiriske tilstand af resigneret og illusionsfyldt underkastelse under kapitalen. Standpunktet er ikke vulgært empiristisk, ikke arbejderistisk - misforstå endelig ikke. Men den kritiske reference er på basis af den teoretiske erkendelse af lønarbejdets nøglerolle i det kapitalistiske produktionsforhold begrebet om den proletariske arbejderbevæ- 
gelse, som fra i dens elementære og objektive eksistens at være sat af og $i$ kapitalismen modnes til kollektivt og subjektivt at rejse sig selvstændigt overfor kapitalismen i en praktisk tilintetgørende emancipationskamp mod kapitalismen.

Netop hér henter teorien sin »kritiske normativitet«. Netop i begrebet om den proletariske arbejderbevægelse, den praktisk-revolutionære massekamp, den kollektive klassesubjektivitet - kært barn har mange navne - finder teorien en kritikinstans immanent i sin genstand. En kritikinstans, som ud over at være i genstanden også gennem genstandens egen bevægelse udstyres med potentialer for praktisk at selvstændiggøre sig til at $» s t a ̊$ ved siden af eller ganske udenfor « genstanden. Den eneste kritikinstans endelig, som overhovedet sidder inde med de nødvendige midler og kræfter til realistisk at vælte kapitalismen omkuld i frigørende retning.

\section{Kritikken's grænser.}

Ovenstående meget grove markering af en »normativitet « tilfredsstiller muligvis ikke NL/P's efterlysning af mere konkrete holdepunkter for en overskridende kritik. Og sandt nok er det som markering også kun titelbladet til et helt katalog af mere konkrete spørgsmål og problemer. Men når der nu helt generelt efterlyses orienteringspunkter og når det sker i en tid, hvor stadig flere akademiske marxister synes at tvivle på alt og selv give sig hen i orienteringsløsheden, så bliver selv det mest banale åbenbart en sang værd. Den Marx'ske teori er ikke uden orientering, men rettet mod »proletariatets verdenshistoriske praksis «, og kun reflekteret i denne giver alle $\varnothing v-$ rige og mere detaljerede spørgsmål mening.

Hvad angår spørgsmålet om en nærmere »positivering «, om mere håndfaste referencepunkter for en overskridende kritik, så er der gode grunde til at være tilbageholdende.

Allerførst må vi med den marxske dialektik skelne strikt mellem "proletariatets revolutionære diktatur « og »det klasseløse kommunistiske samfund «, dvs. mellem de umiddelbart frigørende handlinger i den omvæltende proces og de frigjorte handlinger $\mathrm{i}$ fremtidens nye samfund. I systematisk forstand er denne skelnen hos Marx tematiseret som en forskel mellem »negationens negation« og »det absolut, på sig selv beroende positive«. Negationens negation er endnu som ophævende og bagudrettet bevægelse overvejende belastet netop af negativiteten, og en absolutering af dette moment vil følgelig være farligt bevarende. Det virkeligt positive begynder først, hvor negationens negation er forladt og hvor det positive udgår selvstændigt fra sine egne adækvate betingelser for sine egne mål.

Anvendt som ramme for diskussionen af frigørelsen og dens naturlige strækken sig ud i proletariatets diktatur og det klasseløse samfund gør denne logiske skelnen det klart, at der ikke bare - som i den ældre Marx' svage formulering - er tale om forskellig grad af fødselsmærker og restlevninger fra kapitalismen, men om direkte 
forskellige rationaliteter. Og det bliver ligeledes klart, at det absolut positive, de egentlige »kommunistiske principper «, ligger fuldstændig uden for rækkevidde. Her gælder, hvad der også fremføres i »Karl Marx og den moderne verden «, at forestillingerne kun kan være spekulativt negative - som fravar af klasse- og standsforskelle, af udbytning og undertrykkelse, af stat og nationale grænser etc. Og funktionen af sådanne forestillinger ligger da heller ikke i den fremtid, som de peger på, men i det bestående og dets opløsningsproces.

Men er det så til gengæld ikke muligt og nødvendigt at reflektere nærmere over selve negationens negation, overgangstiden og de omvæltende og frigørende handlinger? Har ikke den russiske revolution og den spanske kollektivbevægelse bragt spørgsmålet om dét som bør være mere håndgribeligt ind i dét som har været og dermed dét som er? Har vi ikke historisk fået en række erfaringer, som må skrives til erfaringerne fra forrige århundrede og som sammen med disse må omsættes i mere konkrete »normsætninger « for »proletariatets revolutionære diktatur $\ll$ ?

Svaret må her blive et klart jo. De tabte revolutioner indeholder både positive og negative erfaringer, som må fastholdes og gøres gældende fremover. Til erfaringen om den revolutionære kommune er kommet erfaringerne med arbejderrådene, de selvstændige og autentiske organer for den kollektive konstitution af det revolutionære klassesubjekt. Hvad angår spørgsmålet om magten, om pro- letariatets demokratiske diktatur, om fagforeningernes og partiernes rolle, om produktions- og distributionsforhold, om udviklingsopgaver etc. etc. har den kapitalistiske historie leveret ganske betydelige erfaringer, som teorien må forarbejde.

Men selv her må den kritiske reflektion mane til omtanke og forsigtighed. De gjorte erfaringer er overvejende negative og deres budskab er at undgå gentagelser. Historien producerer et voksende katalog over hvad der ikke bør gøres, kun meget lidt om hvad der faktisk kan gøres. Ud over måske selve begrebet om arbejderråd eller selvorganiserede revolutionære masseorganer er der igen positive holdepunkter. Erfaringerne bliver blot understregninger af helt almene formler, som allerede Marx gav, nemlig at arbejdernes frigørelse kun kan være arbejderklassens eget værk og at arbejderne ikke bare kan overtage det bestående statsmaskineri, men nødvendigvis må destruere det. Erfaringerne kan konkretisere og illustrere disse principper, men de kan ikke omsættes i »normer « uden at blive skematisk formalisme.

Til alt dette kommer endelig det kritisk-materialistiske standpunkt, at frigørelsen ikke bliver iværksat af ideelle grunde, men af praktisk nødvendighed. Proletariatet eller den revolutionære massebevægelse griber ikke magten for at realisere ideer, hverken en umiddelbar omvæltningsplan eller abstrakte forestillinger om »kommunismen«. Konstitutionen overhovedet af en praktisk kollektivbevægelse, der selvstændigg ør 
sig overfor det borgerlige samfund og modnes i handlinger til at udøve et revolutionært diktatur, er en ganske konkret erfaringsdialektik over kampen for umiddelbare behov og interesser. Et sted i denne kamp spiller historisk akkumulerede erfaringer og teoretiske budskaber selvfølgelig en vis rolle. Men det kan være på et meget lille sted. Ingen teori og dermed heller ikke nogen særlig kritisk »normativitet« kan bevæge noget som helst, hvis det ikke allerede er i bevægelse og selv i færd med de opgaver, som teorien omhandler. $\mathrm{Og}$ selv her er teoriens rolle forsvindende, idet opgaven ofte først stiller sig samtidigt med midlerne til dens løsning og således gør resultaterne til en ren List der Vernunft, hvor den overskridende handling er udført før den er tænkt.

Nuvel - dette var blot en hastig reaktion på NL/P's krav om kritisk $»$ normativitet « og deres for mig at se uheldige formulering af dette krav. »Kritisk normativitet « må ikke føre til opgivelsen af dialektikken og den immanent kritiserende begrebslogik. Den immanente enhed og modsætning mellem dét som er og dét som bør være må fastholdes mod alle tendenser til at adskille det sammenhørende og genrejse typisk neo-kantianske og etisk socialistiske argumentationsbaner. Teorien hverken kan eller skal opfinde andre »kritiske normer « end dem, der opstår af og i kapitalismen selv og har kapitalismens praktiske overvindelse som nødvendig implikation og muligt perspektiv. Til gengæld skal teorien så også være konsekvent og forpligtiget på disse »normer «, når såvel den historiske erfaring som den teoretiske begrebssætning - trods alle nederlag og trods kapitalismens fortsatte modernisering - fortsat tilsiger dem som eneste udvej. 


\section{nyt hos KURASJEs Bogimport SYMPOSION BOKFÖRLAG}

Hans Peter Duerr

Drömtid - Om gränsen mellan det vilda och civiliserade $\ldots \ldots \ldots \ldots$ kr. $\quad 123,00$ Jan Thavenius

Liv och historia - Om människan i historien och historien i människan $\ldots$ kr. $\quad 132,00$

Rudi Dutschke

Gå upprätt - En fragmentarisk självbiografi $\ldots \ldots \ldots \ldots \ldots \ldots \ldots \ldots$ kr. 111,00

Rudi Dutschke

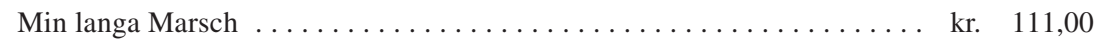

Donald Broady

Den dolda lärorplanen $\ldots \ldots \ldots \ldots \ldots \ldots \ldots \ldots \ldots \ldots \ldots \ldots \ldots \ldots \ldots$ kr. $\quad 42,00 \ldots \ldots$

Jan Thavenius

Modersmål och fadersarv kr. 111,00

Bestil bøgerne direkte hos

KURASJE, Krystalgade 16, 1172 København K.

Særrabat for abonnenter. 


\section{Bøger af}

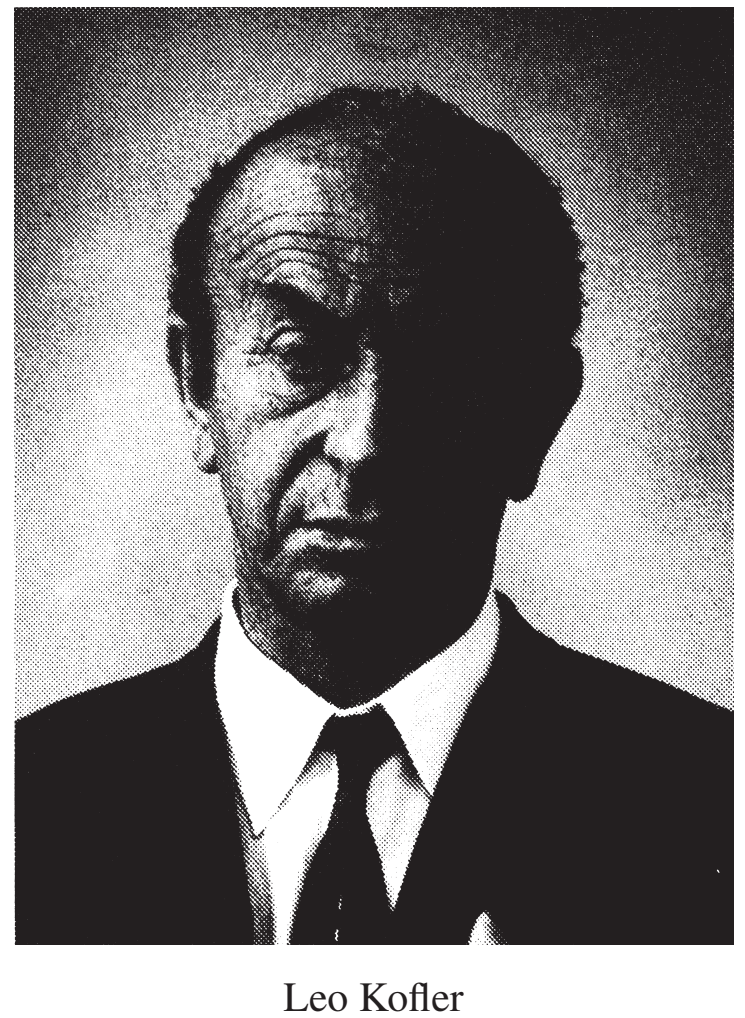

Zur Kritik der »Alternativen «

dkr. 58,-

Der Konservatismus. Zwischen Dekadenz und

Reaktion dkr 44,-

Beherrscht uns die Technik? dkr 89,og splinterny:

EROS - ÄSTHETIK - POLITIK. Thesen zum

Menschenbild bei Marx dkr 58,-

\section{HOS KURASJES BOGIMPORT} Send os et brev eller giro 
Det er nu der skal tegnes abonnement på de næste 4 numre af KURASJE, nemlig nr. 37-40. Det koster kun $180,-$ kr. for alle 4 hæfter (kun 140,- kr. for studerende). Simpelthen så billigt at det er for dyrt at fotokopiere KURASJE. Indbetal på giro.

\section{KURASJE er et kritisk marxistisk tidsskrift.}

Kurasje søger med en række forskellige indfaldsvinkler at præcisere en teoretisk kritik af vort kapitalistiske samfund og af de socialistiske lande, som udgangspunkt for en diskussion af mulige overgangsformer til et kommunistisk samfund. KURASJE bringer såvel artikler der søger at nytænke og videreudvikle en aktuel og radikal samfundskritik, som artikler der søger at skabe overblik og sammenhæng i den internationale marxistiske diskussion.

Du kan købe bøger fra de førende tyske og svenske venstreorienterede forlag billigst direkte hos KURASJE BOGIMPORT: Rotbuch, Merve, VSA, Frauenoffensive, Röda Bokforlag, Symposium, m.fl. Send et brev, og vi sender straks bøgerne. Rekvirer vort katalog over udenlandske bøger og over litteratur om kvinder.
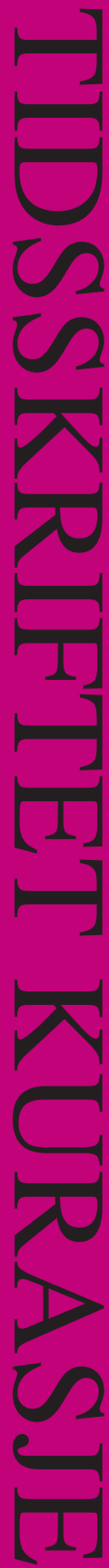